$$
\text { UNIVERSIDADE DE SÃO PAULO }
$$

FACULDADE DE FILOSOFIA, LETRAS E CIÊNCIAS HUMANAS DEPARTAMENTO DE LETRAS CLÁSSICAS E VERNÁCULAS PROGRAMA DE PÓS-GRADUAÇÃO EM LITERATURA PORTUGUESA

MARCELO LACHAT

Narração e doutrina na Constante Florinda: exempla estóicos para a vida cristã 


$$
\text { UNIVERSIDADE DE SÃO PAULO }
$$

FACULDADE DE FILOSOFIA, LETRAS E CIÊNCIAS HUMANAS DEPARTAMENTO DE LETRAS CLÁSSICAS E VERNÁCULAS PROGRAMA DE PÓS-GRADUAÇÃO EM LITERATURA PORTUGUESA

\title{
Narração e doutrina na Constante Florinda: exempla estóicos para a vida cristã
}

Marcelo Lachat

\begin{abstract}
Dissertação apresentada ao Programa de Pós-Graduação em Literatura Portuguesa do Departamento de Letras Clássicas e Vernáculas da Faculdade de Filosofia, Letras e Ciências Humanas da Universidade de São Paulo, para a obtenção do título de Mestre em Letras.
\end{abstract}

Orientadora: Profa. Dra. Adma Fadul Muhana 
Para minha mãe,

toda palavra. 


\section{Agradecimentos}

À minha família: meus pais, Claudio e Nicea, meus irmãos, Claudia e Mauricio, meus cunhados, Paulo e Carol, e meu sobrinho, Ricardo. Com eles começo e a eles sempre me volto.

À professora Adma Muhana, que me mostrou estas ruínas e me ensinou a ler seus vestígios.

Aos professores João Adolfo Hansen, Leon Kossovitch e Maria do Socorro Fernandes de Carvalho, "porque melhor é errar um seguindo conselhos alheios, do que acertar fiado em seus pareceres próprios”.

Aos professores Anne-Marie Quint e Artur Henrique Ribeiro Gonçalves, que gentilmente me enviaram seus textos.

Aos meus amigos, em especial, a Bruno Penteado, Flávio Antônio Fernandes Reis e Lenon Rogério de Melo Franco. "Sea el amigable trato escuela de erudición, y la conversación enseñanza culta; un hacer de los amigos maestros, penetrando el útil del aprender con el gusto del conversar".

A Marcus Vinicius Monteiro Peres, funcionário da Divisão de Informação Documental da Fundação Biblioteca Nacional, sempre solícito.

À Fundação de Amparo à Pesquisa do Estado de São Paulo (FAPESP), pela bolsa concedida.

A Renata, por fim, porque desde o começo foi mão segura entre medos. 


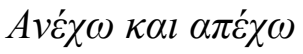

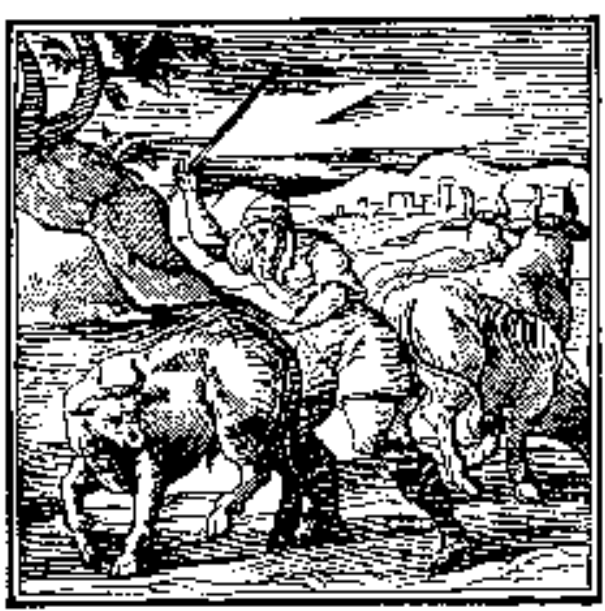

Et toleranda homini tristis fortuna ferendo est, Et nimium felix saepe timenda fuit. Sustine (Epictetus dicebat) et abstine. Oportet Multa pati, illicitis absque tenere manus. Sic ducis imperium vinctus fert poplite taurus In dextro: sic se continet a gravidis.

(Andrea Alciati. Emblematum liber)

Los ojos humanos se ocupan en mirar enigmas.

(Francisco de Quevedo. Providencia de Dios) 


\section{Resumo}

Os Infortúnios trágicos da constante Florinda, de Gaspar Pires de Rebelo, foram publicados em 1625. Devido ao sucesso alcançado pelo texto, veio a público, em 1633, uma continuação intitulada Segunda parte da Constante Florinda, em que se trata dos infortúnios que teve Arnaldo buscando-a pelo mundo. A Constante Florinda (esse é o título pelo qual as duas partes da obra, em conjunto, ficaram conhecidas), muito lida nos séculos XVII e XVIII, foi praticamente esquecida nos séculos seguintes. Este nosso trabalho tem como objetivo analisar a referida obra, evidenciando os procedimentos retóricos e poéticos e os ensinamentos estóico-cristãos que constituem a narração e a doutrina da Constante Florinda. Tendo em vista tal propósito, o estudo, num primeiro momento, volta-se para os preceitos retóricos e poéticos que permitem pensar-se numa ars narrandi, ou seja, uma técnica de narrar que o narrador, como persona gnara, conhece e sabe empregar ao relatar os infortúnios trágicos de Florinda e Arnaldo. Se um dos ofícios dessa narração é ensinar algo para os leitores, já que estes devem ser movidos não apenas pelo deleite, mas também pelo proveito, nosso trabalho, num segundo momento, discute as lições das histórias narradas. Assim, o que buscamos demonstrar é que o proveito da narração dos infortúnios de Florinda e Arnaldo ecoa os ensinamentos da doutrina estóico-cristã dos séculos XVI e XVII, difundida por autores como Justo Lípsio e Francisco de Quevedo. Ressalta-se neste trabalho, por fim, o seu próprio artifício. Apenas no nosso estudo narração e doutrina podem ser separadas, pois no texto da Constante Florinda tudo se dá simultaneamente: a narração já é doutrina, e mostra aos leitores, com exempla estóicos, os caminhos (trágicos) do viver cristão.

Palavras-chave: Literatura Portuguesa; Séculos XVI e XVII; Retórica; Poética; Filosofia Estóica 


\begin{abstract}
Gaspar Pires de Rebelo's Infortúnios trágicos da constante Florinda was published in 1625. Given its conspicuous success, a sequel, Segunda parte da Constante Florinda, em que se trata dos infortúnios que teve Arnaldo buscando-a pelo mundo, came out in 1633. Constante Florinda (this is the title both parts became known as), largely disseminated in the 17th and 18th centuries, was nonetheless virtually forgotten in the subsequent centuries. This dissertation intends to analyze the aforementioned work, so as to highlight not only rhetorical and poetic procedures, but also stoic-christian lessons which lie beneath both the narrative and the doctrine of Constante Florinda. Bearing this goal in mind, this study will first focus on rhetorical and poetic precepts which render it possible to think about the ars narrandi, that is to say, a narrative technique that the narrator (as persona gnara) deeply understands, thus being able to employ it when reporting the tragic misfortunes of Florinda and Arnaldo. If one of the purposes of this narration is to teach something to its readers, since the latter must be moved not only by delight, but also by profit, we also intend to adduce the lessons of the stories the narrator tells. Therefore, we mean to demonstrate that the profit from the narration of Florinda's and Arnaldo's misfortunes reflects 16th and 17th-century stoic-christian doctrine, profoundly advertised by authors such as Justus Lipsius and Francisco de Quevedo. Last but not least, our dissertation has it as an inherent intention to stress its artifice. Only in our study can narration and doctrine be set apart, since in Constante Florinda they emerge simultaneously: narration is also doctrine, and conveys the (tragic) paths, with stoic exempla, of christian life.
\end{abstract}

Key words: Portuguese Literature; 16th and 17th Centuries; Rhetoric; Poetics; Stoic Philosophy 


\section{Sumário}

INTRODUÇÃO

\section{CAPÍTULO 1}

A narração: preceitos retóricos e poéticos..

.17

\section{CAPÍTULO 2}

O narrador da Constante Florinda:

uma persona que narra.

\section{CAPÍTULO 3}

Filosofia estóica nos séculos XVI e XVII:

uma doutrina estóico-cristã.

\section{CAPÍTULO 4}

Ensinamentos estóico-cristãos

na narração da Constante Florinda.

.151

\section{CONSIDERAÇÕES FINAIS:}

Palavras e coisas ou narração e doutrina. 180 


\section{Introdução}

Um primeiro risco para quem se propõe a analisar um texto do século XVII é considerá-lo, precipitadamente, "barroco". Esse uso dedutivo do termo, estranho aos escritos seiscentistas, advém da manutenção de uma tradição idealista da historiografia da arte do século XIX; em especial, decorre da noção de "barroco" formulada por Heinrich Wölfflin, em sua obra Renaissance und Barock (1888). ${ }^{1}$ Até o começo do século XVIII, a palavra "barroco" não designava qualquer "estilo", "período" ou “movimento" artístico (ou literário), sendo empregada, principalmente, para significar uma pérola irregular, como se verifica, por exemplo, no Vocabulário Português e Latino de Rapahel Bluteau, em que a palavra é assim definida: "Barrôco. Perola tosca, $\&$ desigual, que nem he comprida, nem redonda. Unio, dives $œ$ ab rotundâ, \& turbatâ in figure". 2 E a própria escolha desse termo indica uma concepção dedutiva da história literária, que classifica autores e obras segundo estilos e épocas pré-determinados: as jóias bem polidas e regulares do classicismo teriam dado lugar às pérolas toscas e deformadas do barroco. Como consequiência desse modo de avaliar a "Literatura" (uma palavra também bastante inadequada para designar os textos do século XVII), as representações seiscentistas foram, acriticamente, transformadas em "barroco", cuja noção, como explica João Adolfo Hansen, promove uma interpretação idealista, "que generaliza as categorias neoclássicas para fundamentar as avaliações da poesia seiscentista como 'excesso', 'jogo de palavras', 'alambicamento', 'artificialismo', 'formalismo', 'niilismo temático', 'afetação', 'pedantismo' e mais anacronismos". ${ }^{3} \mathrm{E}$ isso vale não apenas para a poesia: a prosa seiscentista também foi e continua sendo, muitas vezes, assim julgada.

\footnotetext{
${ }^{1}$ Cf. Hansen, João Adolfo. "Barroco, Neobarroco e Outras Ruínas". In: REEL - Revista Eletrônica de Estudos Literários. Vitória, a.2, n.2, 2006, pp.1-4. Disponível em: http://www.ufes.br/ mlb/reel2/ JoaoAdolfoHansen.pdf

${ }^{2}$ Vocabulario Portuguez, e Latino. Coimbra: No Collegio das Artes da Companhia de Jesu, 1712-1713, vols.1-4. Lisboa Occidental: Na Officina de Pascoal da Sylva, 1716-1721, vols. 5-8. Suplemento ao Vocabulario Portuguez, e Latino. 2v. Lisboa Occidental: Na Officina de Joseph Antonio da Sylva, 1727; $\mathrm{Na}$ Patriarcal Officina da Musica, 1728. Consultamos a seguinte edição fac-similada: Hildesheim; Zürich; New York: Georg Olms Verlag, 2002. 10v.

3 "Fênix renscida \& Postilhão de Apolo: Uma introdução". Poesia seiscentista - Fênix renascida \& Postilhão de Apolo. 1ªd. São Paulo: Hedra, 2002, p.26.
} 
Para escapar de tal idealização, uma possível saída é recorrer ao "conjunto das Letras" que enforma os textos seiscentistas e, em particular, às technai retórica e poética. Em vez de buscar afoitamente aquelas características "barrocas" de uma obra do século XVII, parece mais produtivo tentar identificar procedimentos retóricos e poéticos que, em grande medida, constituem o texto. Autores como o mencionado Hansen, Alcir Pécora e Adma Muhana, entre outros, vêm, há algum tempo, estudando a poesia e a prosa seiscentistas, buscando adequar a nossa compreensão contemporânea a textos que ignoram romantismos, nacionalismos, subjetivismos, realismos $\mathrm{e}$ modernismos.

E partindo dessa perspectiva nada "barroca", é que almejamos, neste trabalho, refletir sobre narração e doutrina na Constante Florinda, uma obra muito lida nos séculos XVII e XVIII ${ }^{4}$ e praticamente esquecida nos séculos seguintes, sendo revitalizada apenas recentemente como objeto de estudo de alguns pesquisadores. A Constante Florinda, título pelo qual ficou conhecida, é composta por duas partes. A primeira (intitulada Infortúnios trágicos da constante Florinda) teve sua editio princeps em 1625, da qual não se conhecem exemplares, sendo a impressão de 1633 a mais antiga de cujos exemplares se tem notícia. ${ }^{5}$ Já a editio princeps da continuação (Segunda parte da Constante Florinda, em que se trata dos infortúnios que teve Arnaldo buscando-a pelo mundo) é de 1633, porém os primeiros exemplares conhecidos do texto são os da impressão de $1635 .{ }^{6}$ Do autor da Constante Florinda, Gaspar Pires de Rebelo, chegaram até nós mais duas obras: uma doutrinária, intitulada Tesouro de pensamentos concionativos $(1635),{ }^{7}$ e outra ficcional, editada postumamente, chamada Novelas Exemplares (1650), ${ }^{8}$ seguindo o modelo das Novelas Ejemplares de Cervantes.

\footnotetext{
${ }^{4}$ Para confirmar a ampla circulação da Constante Florinda, vale a pena elencar as suas diversas edições seiscentistas e setecentistas. Da primeira parte: Lisboa, por Giraldo da Vinha, 1625; Lisboa, por António Álvares, 1633; Coimbra, pela viúva de Manuel de Carvalho, 1665; Lisboa, por João da Costa, 1672; Lisboa, por Bernardo da Costa de Carvalho, 1707; Lisboa, por Filipe de Sousa Vilela, 1707. Da segunda parte: Lisboa, por António Álvares, 1633; Lisboa, por António Álvares, 1635; Coimbra, pela viúva de Manuel Carvalho, 1671; Lisboa, por Bernardo da Costa de Carvalho, 1708; Lisboa Oriental, por Filipe de Sousa Vilela, 1721. Das duas partes em conjunto: Lisboa, por Domingos Carneiro, 1684; Lisboa, por Domingos Carneiro, 1685; Lisboa, por Herdeiros de António Pedroso Galrão, 1747; Lisboa, por Francisco Borges de Sousa, 1761. Essas informações podem ser consultadas na tese de doutorado de Artur Henrique Ribeiro Gonçalves: Infortúnios Trágicos da Constante Florinda de Gaspar Pires de Rebelo: Uma Novela de Amor e Aventuras Peregrinas. Lisboa: Universidade Nova de Lisboa, 2000, pp.xliii-xlv.

${ }^{5}$ Infortunios Tragicos da Constante Florinda. Lisboa: António Álvares, 1633.

${ }^{6}$ Segunda Parte da Constante Florinda: Em que se trata dos infortunios que teve Arnaldo buscandoa pelo mundo. Lisboa: António Álvares, 1635.

7 Thesouro de Pensamentos concionativos sobre a explicação dos misterios sagrados, \& cerimonias sanctas do Sanctissimo Sacrificio da missa, \& significação das vestiduras sacerdotais com que ele se
} 
Pouco se sabe sobre a vida de Gaspar Pires de Rebelo, desconhecendo-se mesmo o ano de seu nascimento. As fontes biográficas mais confiáveis são as folhas de rosto das obras que publicou. Ele teria nascido na vila do Aljustrel, na região do Alentejo, antes de 21 de julho de 1585. Foi freire professo da Ordem de Santiago, cujo hábito recebeu em 1610. Em 1625, tornou-se prior da Igreja Matriz de Castro Verde, na comarca de Campo de Ourique. Sabe-se também que foi licenciado, mas não há informações seguras sobre quais foram seus estudos. Ele teria morrido antes de 20 de novembro de 1642, pois nessa data, conforme um documento referido por Adma Muhana, "dom João IV transmite a Gaspar Alonso de Medeiros o priorado da Igreja Matriz da Vila de Castro Verde, que está vago 'por falecimento de Gaspar Pires de Rebelo, freire professo dela e do dito priorado último e imediato possuidor...' [Arquivo Nacional da Torre do Tombo, Chancelaria da Ordem de Santiago, Livro 14, fl.76v]". 9

Nos compêndios de história literária, a Constante Florinda é quase sempre ignorada. E quando há alguma menção à obra ou ao autor, as palavras gastas com o assunto, além de denotarem uma excessiva economia, são também de pouca qualidade, e o tom é, na maior parte das vezes, depreciativo. Para exemplificar, vejamos o que dizem António José Saraiva e Óscar Lopes na História da Literatura Portuguesa. Gaspar Pires de Rebelo e sua Constante Florinda são referidos em poucas linhas, num insignificante adendo ao capítulo dedicado a D. Francisco Manuel de Melo (capítulo II, “Época Barroca”):

Aproveitamos o ensejo para registar a continuidade, na época barroca, da ficção sentimental iniciada pela Menina e Moça, por vezes com esboços de caracterização psicológica interna, mas muito prejudicados, como vimos em Manuel de Melo, por um preciosismo descritivo, sentencioso e moralizante que permeia a narrativa $\mathrm{e}$ as falas ou missivas modelares, até ao quase inevitável happy end nupcial. $\mathrm{O}$ êxito editorial do género foi extraordinário. Verifiquemo-lo: Infortúnios trágicos da constante Florinda ( $1^{\mathrm{a}}$ parte 1625 , reed. 1655, 1672, 1707, $2^{\mathrm{a}} 1633$, reed. 1671 ; reed. globais 1684,1761 ; constitui excepção à regra optimista, pois é uma das versões romanescas da lenda de

celebra, ordenado em forma de dialogo a hum Sacerdote, \& seu Ministro. Lisboa: António Álvares, 1635 .

${ }^{8}$ Novelas Exemplares. Lisboa: António Álvares, 1650.

${ }^{9}$ Infortúnios trágicos da constante Florinda. Organização, notas e posfácio de Adma Muhana. São Paulo: Globo, 2006, p.325. 
Alatabada, Alacaba ou Cava, nome depois alterado para Florinda, filha do rei Rodrigo violada pelo conde Julião de Ceuta, lenda já pateticamente contada na Crónica Geral de 1344) e as Novelas Exemplares, 1650, reed. 1670, 1684, 1700, 1712, 1761, do padre Gaspar Pires de Rebelo... ${ }^{10}$

São essas as únicas palavras - e, como se nota, pouco precisas e muito tendenciosas - que Saraiva e Lopes destinam à Constante Florinda e ao seu autor. Já Gaspar Simões, em sua História do Romance Português, chega a dedicar algumas páginas às obras de Rebelo; porém, o teor de suas considerações é ainda mais ostensivamente depreciativo. Ilustremos com o seguinte trecho:

Cronològicamente, o padre Gaspar Pires de Rebelo, natural de Aljustrel, prior de Castro Verde, e da Ordem de Sant'Iago de Espada, é o primeiro novelista sentimental do século XVII. Custa a crer, mas suas obras caíram no gosto do leitor. Tanto a sua novela Infortúnios Trágicos da Constante Florinda, em duas partes, publicadas em Lisboa em 1625 e 1665, como as suas Novelas Exemplares, dadas à estampa, igualmente em Lisboa, em 1670, imprimiram-se e reimprimiram-se. (...) É em travesti que a Constante Florinda percorre meio mundo, essa Constante Florinda que debalde tenta ganhar vida e sentimentos, para concorrer com qualquer das heroínas do mestre das Novelas Ejemplares - uma La Gitanilla ou Ilustre Fregona. E nem sequer pode dizer-se que é a preocupação da exemplaridade que tolhe os movimentos do escritor, impedindo-o de dar vida às suas personagens. Uma incapacidade radical para a criação novelística abafa quaisquer possíveis dons de imaginação manifestados na intricada trama quer dos Infortúnios Trágicos quer das Novelas Exemplares do mesmo autor. A acção imotivada e arbitrária desenrola-se em cenas que distinguem umas para as outras, num empastamento em que é impossível distinguir o desenho das personagens ou o dos seus gestos mais elementares. Quando, porventura, o autor se detém no retrato de qualquer delas, fá-lo com um verbalismo de tal modo arrebicado e precioso que os tropos desviam a

\footnotetext{
${ }^{10}$ História da Literatura Portuguesa. 10ª edição, corrigida e actualizada. Porto: Porto Editora, 1978,
} pp.520-521. 
atenção do leitor do débil plano intriga para a afectada e artificiosa trama do estilo, em geral de muito mau gosto. ${ }^{11}$

Felizmente, mesmo diante de palavras tão desistimulantes, alguns pesquisadores se interessaram pelos textos de Rebelo e passaram a lê-los criticamente; leitura crítica essa que talvez tenha faltado à grande parte dos autores de compêndios de história literária. É pertinente, então, mencionar alguns daqueles estudiosos. João Palma-Ferreira editou uma das Novelas Exemplares de Gaspar Pires de Rebelo, $O$ desgraciado amante Peralvilho, em sua coletânea Novelistas e contistas portugueses dos séculos XVII e XVIII. ${ }^{12}$ Além disso, Palma-Ferreira considerou essa novela de Rebelo a pioneira do gênero picaresco em Portugal. Mas foi Artur Gonçalves quem primeiro consagrou estudos integrais às obras do frei Gaspar Pires de Rebelo. No seu trabalho inicial, analisou aquela mesma novela exemplar, O Desgraciado amante, inserindo-a, na esteira de Palma-Ferreira, no gênero picaresco. ${ }^{13}$ Seu estudo mais extenso e detalhado, porém, teve como foco a Constante Florinda. ${ }^{14}$ Nele, essa obra de Rebelo é cuidadosamente examinada e definida, em última instância, como uma "novela de amor e aventuras peregrinas grego-bizantinas modernas". Uma contribuição bastante valiosa de Artur Gonçalves, nesse mesmo trabalho, foi ter apresentado uma edição louvável (a primeira contemporânea) das duas partes que compõem a Constante Florinda. Por fim, podemos mencionar, ainda de Gonçalves, a sua "Lição" sobre $A$ Retórica da Citação Pedagógica em Gaspar Pires de Rebelo, dividida em duas partes: na primeira, há uma introdução teórica do assunto; e na segunda, apresenta-se o Corpus Sententiarum de Rebelo. ${ }^{15}$

Além desses dois pesquisadores, Adma Muhana também refletiu sobre os escritos do autor da Constante Florinda. Na sua definição do gênero "epopéia em prosa seiscentista", a estudiosa, investigando diversos textos de variados autores, discutiu os preceitos poéticos e retóricos que permitiram a constituição daquele gênero e explicitou as técnicas empregadas nas epopéias em prosa do século XVII; entre essas obras, foi

\footnotetext{
${ }^{11}$ História do Romance Português. V.1. Lisboa: Estúdios Cor, 1967, pp.197-198.

${ }^{12}$ Novelistas e contistas portugueses dos séculos XVII e XVIII. Selecção de João Palma-Ferreira. Lisboa: Imprensa Nacional-Casa da Moeda, 1981.

${ }^{13}$ Uma novela pícara portuguesa: O Desgraciado Amante, de Gaspar Pires de Rebelo. Dissertação para a obtenção do grau de mestre. Lisboa: Universidade Nova de Lisboa, 1994.

${ }^{14}$ Trata-se da sua tese de doutorado, já referida, intitulada Infortúnios Trágicos da Constante Florinda de Gaspar Pires de Rebelo: Uma Novela de Amor e Aventuras Peregrinas.

${ }^{15}$ A Retórica da citação Pedagógica em Gaspar Pires de Rebelo (Frade Seiscentista da Ordem de Santiago). Lição para acesso à categoria de Professor-Coordenador. Faro: Universidade do Algarve, Escola Superior de Educação, 2002.
} 
analisada a Constante Florinda. ${ }^{16}$ A mesma Adma Muhana editou, há pouco tempo, os Infortúnios trágicos da constante Florinda, como sabemos, a primeira parte da epopéia em prosa de Rebelo. ${ }^{17}$ Nessa edição, há um cuidadoso "posfácio”, no qual Muhana examina aspectos da filosofia estóica quinhentista e seiscentista, visando a esclarecer algumas questões que permeiam a "doutrina" da Constante Florinda.

Outro nome que deve ser referido é Anne-Marie Quint. Essa autora vem publicando uma série de artigos sobre as obras de Gaspar Pires de Rebelo. Mencionaremos apenas dois deles, pois são os que tratam, especificamente, da Constante Florinda: "Gaspar Pires de Rebelo, explorateur de nouvelles voies romanesques au Portugal"" e "Tragiques Infortunes: Violence et transgression dans les romans de Gaspar Pires de Rebelo". ${ }^{19}$

Para encerrar, é preciso lembrar que Nuno Júdice também editou, recentemente, as duas partes da Constante Florinda ${ }^{20}$ Como "introdução" a essa edição, há um pequeno texto de Júdice, "Gaspar Pires de Rebelo: Um gênio da Língua e da Literatura", cujo título já deixa transparecer seu caráter panfletário e, conseqüentemente, pouco crítico.

Pois bem. É preciso, finalmente, explicar no que consiste este nosso trabalho. O que se busca nele é analisar a narração e a doutrina da Constante Florinda. Para fazer isso, o estudo está dividido em duas partes, correspondentes àqueles dois assuntos que, como mostraremos nas considerações finais, tratam-se, na verdade, de um só. $\mathrm{Na}$ primeira parte, iniciamos com um capítulo que visa a discutir a noção de narração segundo uma perspectiva retórico-poética. Pensando na narração, é que tratamos também do narrador: os preceitos de como se deve narrar nos levam à persona que narra. Assim, nesse primeiro capítulo, embora tenhamos sempre em vista a narração e o narrador da Constante Florinda, examinamos preceitos retóricos e poéticos (inventivos, dispositivos e elocutivos) almejando contribuir para uma questão que julgamos importante e sobre a qual são raros os estudos: a narração em textos fictícios ${ }^{21}$ do século XVII. Mais raros ainda são os trabalhos que se focam nas personae que narram essas

\footnotetext{
${ }^{16}$ A epopéia em prosa seiscentista: uma definição de gênero. São Paulo: Unesp; Fapesp, 1997.

${ }^{17}$ Infortúnios trágicos da constante Florinda. Organização, notas e posfácio de Adma Muhana, op.cit.

${ }^{18}$ In: Mateo Alemán et les voies du roman au tournant des XVIe et XVIIe siècles, Les Cahiers FORELL, Université de Poitiers, 2001, p. 165-176.

${ }^{19}$ In: Hommage au Professeur Claude Maffre, Université de Montpellier III, ETILAL, 2003, p. 117-129.

${ }^{20}$ Infortúnios trágicos da Constante Florinda. Lisboa: Teorema, 2005.

${ }^{21}$ Preferimos o termo "fictîcio" a "ficcional", pois somente aquele primeiro aparece no Vocabulário do Bluteau: "Ficticio. Fingido. Fabuloso. (...) Fictitius, quer dizer cousa, naõ natural, mas feita por Arte" (Vocabulario Portuguez, e Latino, op.cit., verb. "ficticio").
} 
res fictae; e quando se discute algo a respeito, quase sempre as análises se pautam por anacronismos, tais como "autoria", "subjetividade", "narrador benjaminiano", "teorias do récit" e "narratologia". Por isso, num primeiro momento, fizemos uma exposição mais longa e detalhada daqueles preceitos: um de nossos intuitos é mostrar que, nos tratados retóricos e poéticos, há muito ainda o que ser investigado quanto à narração das res fictae. Além disso, pareceu-nos necessário evidenciar que os procedimentos da persona que narra uma "ficção seiscentista" dependem, fundamentalmente, das technai retórica e poética.

No segundo capítulo, então, passamos à análise específica da narração da Constante Florinda. Escolhemos como foco o narrador, porque, em primeiro lugar, seria impossível examinar, neste breve estudo, os inumeráveis relatos dos personagens que interrompem, a todo momento, a narração principal; e se nos centrássemos nas falas de um único personagem, ou mesmo de alguns, perderíamos, possivelmente, uma visão mais ampla da obra: esta ficaria restrita àquelas histórias secundárias. Portanto, decidimos nos focar na persona gnara que conduz a narração da história principal, ou seja, o narrador, que move os leitores pelo deleite e pelo ensinamento, narrando os infortúnios trágicos de Florinda e Arnaldo. Enfim, daquela persona destacaremos as técnicas retóricas e poéticas empregadas para narrar estes infortúnios.

Se um dos ofícios dessa narração é ensinar algo para os leitores, a segunda parte do nosso estudo discute as lições dessa doutrina. Desse modo, o terceiro capítulo do trabalho discorre sobre a filosofia estóica e, principalmente, sobre sua recepção nos séculos XVI e XVII. Isso porque, naquela narração são evidentes os ensinamentos desta filosofia. Para justificar o terceiro capítulo, valem aqueles mesmos argumentos que usamos para explicar os objetivos do primeiro; porém, com um agravante: são ainda mais escassos, pelo menos em língua portuguesa, os estudos que buscaram mostrar os ecos estóicos repercutidos nas obras quinhentistas e seiscentistas (em especial, nos tratados morais). Por isso, propusemo-nos a examinar, detidamente, alguns textos dos séculos XVI e XVII nos quais é explícito o diálogo com a filosofia estóica, que demonstramos constituir, enfim, uma doutrina estóico-cristã. Embora o alvo seja sempre a Constante Florinda, como já afirmamos, julgamos conveniente e necessário também estendermos a nossa investigação acerca desse assunto (a doutrina estóico-cristã), pois é um tema fundamental nas obras quinhentistas e seiscentistas e muito pouco discutido nos trabalhos que tratam dessas mesmas obras. 
Assim, na narração da Constante Florinda, evidenciaremos os ensinamentos estóico-cristãos que contribuem para o proveito que a história de Florinda e Arnaldo proporciona aos leitores: instrui-os para fugirem dos vícios e seguirem as virtudes, pois todo vício será sempre castigado e toda virtude terá sempre seu devido prêmio. Na Constante Florinda, em suma, doutrina-se por meio de exempla estóicos, mas a finalidade é a vida cristã. Para essas discussões, portanto, é que está voltado o quarto capítulo do trabalho, que para esclarecer o proveito da narração, foca-se nas "falas" da persona que narra. A análise da pequena estrutura, que é esta narração, talvez demonstre a importância daquela doutrina estóico-cristã: um grande alicerce, muitas vezes ignorado, das obras construídas nos séculos XVI e XVII.

Para concluir o nosso estudo, buscamos articular essas duas grandes partes do trabalho reunindo narração e doutrina. Em nossas considerações finais, ressaltamos o artifício de uma tal separação entre como se narra e o que se ensina, ou melhor, entre as palavras (uerba) e as coisas (res). Por isso, é a síntese que conclui o estudo: técnicas retóricas e poéticas e ensinamentos estóico-cristãos, narração e doutrina, palavras e coisas, tudo se confunde no texto da Constante Florinda. E essa composição é que nosso trabalho tentou primeiro resolver, para depois reforçar, com uma techne que investiga as palavras para encontrar as coisas, mas que é, ela mesma, palavras que se perderam há muito das coisas. 


\section{Capítulo 1 \\ A narração: preceitos retóricos e poéticos}

Narrar uma obra poética em prosa, no século XVII, pressupõe técnicas e procedimentos descritos e prescritos nas retóricas e poéticas. A persona que narra aquele texto fictício emprega estes procedimentos porque conhece sua techne ou ars, mostrando-se aos leitores como personagem gnarus. ${ }^{22}$ Esse conhecedor da ars narrandi evidencia àqueles que o lêem que a fábula (mythos) é res ficta verossímil, ou melhor, as coisas são narradas como se fossem res factae. Embora tal persona não possa ser confundida com o orador ou com o poeta, são os preceitos retóricos e poéticos que determinam sua narração. E o objetivo deste capítulo do nosso trabalho é justamente expor e discutir alguns desses preceitos. Vale ressaltar que, ao analisarmos a preceptiva que trata da narração, teremos como foco a persona que narra ou o "narrador".

Antes de iniciarmos a discussão dos tratados, é preciso explicar por que utilizaremos o termo "narrador" para denominar aquele que narra uma epopéia em prosa seiscentista. A maior dificuldade está em demonstrar a adequação do emprego de tal palavra em análises de textos escritos antes do século XVIII, já que o substantivo “narrador" só começou a ser usado a partir de 1813, segundo a datação do Dicionário Houaiss. Contudo, nesse mesmo dicionário, também encontramos a etimologia da palavra: "lat. narrator, oris 'o que conta, narrador'”. ${ }^{23}$ Em Cícero e em Quintiliano já há ocorrências do nome latino narrator, como se observa, por exemplo, nos seguintes trechos: "ceteri non exornatores rerum, sed tantum modo narratores fuerunt" (De Oratore, II, XII, 54); "natura enim fingit homines et creat imitatores et narratores facetos adiuvante et vultu et voce et ipso genere sermonis" (Idem, II, LIV, 219); "Pompeius abunde disertus rerum suarum narrator" (Inst. Orat., XI, I, 36). ${ }^{24}$ Portanto, se é comum o uso, nos séculos XVI e XVII, do termo "narração" derivado da narratio latina, conseqüentemente, é adequado se referir ao "narrador", pensando-se no nome

\footnotetext{
${ }^{22}$ É importante lembrar que é do adjetivo gnarus ("que conhece", "sabedor") que se derivou o verbo latino narro ("fazer conhecer", "relatar", "contar"), que, por sua vez, deu origem à palavra narrator ("aquele que narra"). Portanto, podemos dizer que o narrator é gnarus, ou seja, conhece as coisas (res) e sabe contá-las apropriadamente.

${ }^{23}$ Dicionário Houaiss da Língua Portuguesa. Rio de Janeiro: Objetiva, 2001, verb. "narrador".

${ }^{24}$ Encontramos as referências a esses trechos no verberte "narrator" do Oxford Latin Dictionary (Edited by P.G.W.Glare. Oxford: Clarendon Press, 1968-1982).
} 
latino que lhe deu origem: narrator. Enfim, se há narração, é lógico que há aquele que narra $^{25}$ e é etimologicamente apropriado denominá-lo narrador. E examinando a preceptiva que abrange uma, entenderemos melhor as técnicas e os procedimentos empregados pelo outro.

Assim, para começar, vale ressaltar que "narração" era, pelo menos até o ínicio do século XVIII, um termo retórico que designava um momento determinado do discurso, ou seja, tinha uma conceituação fundamentalmente técnica, como é possível verificar na definição de Raphael Bluteau, em seu Vocabulário Português e Latino:

\begin{abstract}
NARRAÇAÕ. Segundo os Rhetoricos, he a parte da oração, em que se narra o caso, ou successo de que se trata. Era a segunda parte dos discursos Oratorios, que se fazião no foro Romano, seguiase immediatamente ao exordio, segundo o estylo dos antigos Oradores. Hũa das mayores excellencias do Historiador he fazer narrações fieis, naturaes, \& claras. Narratio, onis. Fem.Cic. ${ }^{26}$
\end{abstract}

Desse modo, nas retóricas antigas, quando o assunto abordado é a dispositio, recomenda-se, quase sempre, que a narratio seja a segunda parte do discurso, aquela que vem logo após o exordium, isto é, depois de feita a introdução da matéria a ser tratada, o orador deve expor os fatos. ${ }^{27}$ No entanto, não se proíbe que o orador, dependendo da necessidade e obedecendo à conveniência, altere essa ordem ou disposição. $^{28}$

Para enriquecer a compreensão do que o termo "narração" significava até meados do século XVIII, faremos uma exposição do que pudemos encontrar sobre o tema em alguns tratados retóricos e poéticos, além de obras que visavam à instrução do perfeito cortesão, como Il libro del cortegiano, de Baldassare Castiglione, o Galateo, de Giovanni Della Casa, e a Corte na Aldeia, de Francisco Rodrigues Lobo. Nessa exposição de preceitos que nos permitem configurar a narração, buscaremos refletir,

\footnotetext{
${ }^{25}$ É o que podemos confirmar, por exemplo, no Vocabulário Português e Latino: "Aquelle que narra. Narrator. Masc. Cic." (Bluteau, Raphael. Vocabulario Portuguez, e Latino, op.cit., verb. "narrar").

${ }^{26}$ Vocabulario Portuguez, e Latino, op.cit., verb. "narraçaõ".

${ }^{27}$ Cf. Lausberg, Heinrich. Manual de Retórica Literaria. Versión española de José Pérez Riesco. Tomo I. Madrid: Gredos, 1975, p.260.

28 "De igual modo, los autores que tratan explícitamente esta cuestión coinciden en admitir que este orden se puede alterar. Cuándo debe hacerse lo dejan al criterio del orador". Artaza, Elena. El ars narrandi en el siglo XVI español. Teoria y practica. Bilbao: Universidad de Deusto, 1989, p. 123.
} 
especialmente, sobre aquele que narra ou, como mostramos ser adequado denominá-lo, o narrador.

Isso posto, comecemos com aquilo que Aristóteles afirmou sobre a matéria. No Livro III da Retórica, ${ }^{29}$ do capítulo 13 ao 19, o autor ocupa-se das partes que compõem o discurso. Este, na preceptiva aristotélica, pode chegar a se dividir em quatro partes: proêmio, narração, prova e epílogo. No entanto, somente a narração e a prova são verdadeiramente necessárias. Depois de explicar a função do proêmio e de mencionar uma lista (os "tópicos de refutação") com onze tipos de argumentos para remover do auditório atitudes desfavoráveis ao orador, Aristóteles, no capítulo 16, expõe seus preceitos acerca da narração (diegesis). Nessa preceptiva, podemos destacar, primeiramente, que a diegesis não se restringe a uma mera exposição dos fatos, mas requer uma demonstração técnica que seja conveniente à causa, ${ }^{30}$ como se nota no seguinte trecho:

Quanto ao conteúdo do discurso, este é, por um lado, constituído por uma componente exterior à técnica (visto que o orador não é responsável pelos factos relatados); por outro, por uma componente técnica. Esta consiste em demonstrar quer que a acção se realizou, caso não seja credível, quer que ela foi de determinada qualidade ou ordem de grandeza, ou tudo isto ao mesmo tempo (Retórica, III, 16, 1416b).

No gênero judicial, quem acusa não deve narrar de forma demasiadamente rápida, pois "o melhor não é a rapidez ou a concisão, mas sim a justa medida" (Idem, III, 16, 1416b). Já "para o defensor, a narração pode ser mais breve" (Idem, III, 16, 1417a), de modo que não se perca tempo com o que todos já sabem.

Vale a pena destacar também um outro preceito da retórica aristotélica: a narração deve exprimir "caracteres", isto é, tem que ser "ética" (diegesis ethike). Nesse sentido, é pertinente reproduzir o trecho em que é discutida essa questão:

É conveniente que a narração seja 'ética'. Isto assim resulta se soubermos o que produz a expressão de carácter moral. Um recurso é mostrar a intenção moral: o carácter corresponde ao tipo de intenção, e

\footnotetext{
${ }^{29}$ Edição utilizada: Aristóteles. Retórica. Trad. Manuel Alexandre Júnior, Paulo Farmhouse Alberto e Abel do Nascimento Pena. Lisboa: Imprensa Nacional - Casa da Moeda, 1998.

30 "Narra tudo quanto chama a atenção para o teu próprio valor" (Retórica, III, 16, 1417a).
} 
a intenção moral, por sua vez, ao tipo de finalidade. É por isto que os textos matemáticos não expressam caracteres, porque não têm uma finalidade moral (pois não se constituem com tal finalidade); mas os textos socráticos já a têm, pois é sobre tais temas que eles discorrem.

Outros elementos que exprimem os traços morais são os que correspondem a cada um dos caracteres. Por exemplo, 'ao mesmo tempo que falava, pôs-se a andar': isto mostra claramente a arrogância e rudeza de carácter. E não devemos falar com base no raciocínio, como hoje fazem, mas numa intenção: 'eu desejava isto, pois eu tinha esta intenção' e 'mas mesmo que não me tivesse sido proveitoso era o melhor'. A primeira frase é a de um indivíduo sensato, a outra de um homem bom; pois é próprio de um homem sensato perseguir o que é proveitoso, de um homem bom, o que é belo (Idem, III, 16, 1417a).

Portanto, fica evidente a importância do ethos para a narração, o que será de extrema utilidade na análise do narrador da Constante Florinda, pois as palavras deste têm uma nítida finalidade ética e buscam exprimir os traços morais que correspondem ao caráter de cada personagem. Para efetuar esse objetivo "ético", uma maneira eficaz é recorrer ao pathos, narrando pateticamente os fatos (diegesis pathetike), para suscitar os afetos $^{31}$ nos leitores ou ouvintes, persuadindo-os em favor da causa, como recomenda Aristóteles:

\footnotetext{
Além disso, fala de forma a suscitar emoções, narrando tanto as conseqüências que os ouvintes conhecem como os aspectos singulares que correspondem quer a si próprio quer ao opositor: 'olhando-me desdenhosamente, partiu'; ou, por exemplo, como Ésquines diz sobre Crátilo, que este estava a assobiar e a bater palmas. É que estes elementos são persuasivos, pois as coisas que os ouvintes conhecem são sinais que permitem o conhecimento das que não se conhecem (Idem, III, 16, 1417a-1417b).

${ }^{31}$ Preferimos usar o termo "afeto" para designar o pathos retórico, já que não julgamos adequado utilizar a palavra "paixão", como muitos tradutores e comentadores fazem (deixaremos esse último termo para denominar o pathos da ética estóica, por razões que serão explicadas no devido momento). Isso porque, como se lê no Vocabulário Português e Latino do Bluteau, uma das acepções de "affectar" é "agradar aos ouvintes. Delectationem dicendo aucupatur. Cic."; e, no verbete "affecto", aparece, entre os vários sentidos da palavra, o seguinte: "Mover os affectos; he officio do Orador, quando com a voz, \& as acçoens abala os animos dos ouvintes, \& os move a compaixão, a ira, a trifteza, a alegria, \&c. Affectus concitare, movere, commovere, advocare. Quint." (Vocabulario Portuguez, e Latino, op.cit., verbetes "affectar" e "affecto").
} 
Já na Poética ${ }^{32}$, há outros preceitos aristotélicos que nos parecem fundamentais para se pensar a narração e, em especial, a figura do narrador numa obra ficcional seiscentista. Em primeiro lugar, vale citar o modo pelo qual se efetua a imitação na poesia:

Efetivamente, com os mesmos meios pode um poeta imitar os mesmos objetos, quer na forma narrativa (assumindo a personalidade de outros, como o faz Homero, ou na própria pessoa, sem mudar nunca), quer mediante todas as pessoas imitadas, operando e agindo elas mesmas (Poética, III, 1448a, 20-25).

Porém, parecem mais relevantes para nossa análise as idéias contidas no capítulo IX, em que Aristóteles discorre acerca das diferenças entre a poesia e a história. O poeta deve narrar as coisas não como aconteceram, e sim como poderiam ocorrer, sempre respeitando a verossimilhança e a necessidade e visando ao universal.

Pelas precedentes considerações se manifesta que não é ofício de poeta narrar o que aconteceu; é, sim, o de representar o que poderia acontecer, quer dizer: o que é possível segundo a verossimilhança e a necessidade. Com efeito, não diferem o historiador e o poeta, por escreverem verso ou prosa (pois que bem poderiam ser postas em verso as obras de Heródoto, e nem por isso deixariam de ser história, se fossem em verso o que eram em prosa),- diferem, sim, em que diz um as coisas que sucederam, e outro as que poderiam suceder. Por isso a poesia é algo mais filosófico e mais sério do que a história, pois refere aquela principalmente o universal, e esta o particular (Idem, IX, 1451a, $36-40,1451 b, 1-6)$.

Narrando as coisas como poderiam suceder (e não como sucederam), o poeta, assim como o orador, tem que suscitar os afetos dos ouvintes; no caso específico da tragédia, o terror e a piedade (Idem, IX, 1452a, 1-2). Para provocar tais afetos, é necessário saber o que convém e evitar as contradições, ordenando-se as "fábulas" e

\footnotetext{
${ }^{32}$ Edição utilizada: Aristóteles. Poética. Tradução de Eudoro de Souza. Porto Alegre: Globo, 1966.
} 
compondo-se as elocuções das personagens como se tudo ocorresse diante dos olhos de todos (Idem, XVII, 1455a, 22-26).

Além disso, seguindo os passos de Homero, todo poeta "deveria falar menos possível por conta própria, pois, assim procedendo, não é imitador" (Idem, XXIV, 1460a, 7-9). Veremos, no estudo específico da persona que narra a Constante Florinda, que é uma de suas características mais marcantes a intervenção constante na história, com o intuito de guiar o leitor, contrariando, dessa maneira, a recomendação aristotélica. No entanto, outro procedimento condiz mais com aquele narrador que, ao descrever Florinda e Arnaldo, imita Zeuxis, pintando pessoas tão melhores que parecem não existir, mas que são perfeitos exempla, pois, como afirma Aristóteles, "é de preferir o impossível que persuade, ao possível que não persuade" (Idem, XXV, 1461b, 11-12).

Um outro tratado antigo que discute importantes questões para nosso estudo é a Rhetorica ad Herennium. ${ }^{33}$ Nesta, os comentários sobre a narratio estão localizados no Livro I, logo após as considerações a respeito do exórdio no gênero judicial. O termo é definido da seguinte maneira: "Narratio est rerum gestarum aut proinde ut gestarum expositio" (Rhetorica ad Herennium, I, 4), ou seja, a narração é uma exposição das coisas como aconteceram ou como poderiam ter acontecido. E são três seus gêneros: no primeiro, narra-se o fato de modo favorável à causa; o segundo entrecorta o discurso com o objetivo de levantar questões de credibilidade, incriminação, transição de assuntos e preparação; o terceiro, único não-civil, divide-se em dois gêneros: ações e personagens. As espécies de ações são três: a fábula (fatos que não são nem verdadeiros, nem verossímeis, como os relatados nas tragédias), a história (fatos que realmente aconteceram, mas em uma época distante) e o argumento (ações fictícias, mas que poderiam ter ocorrido, como as das comédias). Quanto ao gênero de narração que se apóia em personagens, vale a pena transcrever o trecho, visto que as recomendações do autor anônimo da Rhetorica ad Herennium serão de muita utilidade quando empreendermos a análise da narração da Constante Florinda, principalmente no que se refere às variações repentinas da fortuna (rerum uarietates fortunae commutationem):

Illud genus narrationis, quod in personis positium est, debet habere sermonis festiuitatem animorum dissimilitudinem, grauitatem lenitatem, spem metum, suspicionem desiderium, dissimulationem

\footnotetext{
33 Edição consultada: Retórica a Herênio. Tradução e introdução Ana Paula Celestino Faria e Adriana Seabra. São Paulo: Hedra, 2005.
} 
misericordiam, rerum uarietates fortunae commutationem, insperatum incommodum subitam laetitiam iucundum exitum rerum (Idem, I, 13). ${ }^{34}$

Outra relevante regra prescrita na Rhetorica ad Herennium acerca da narratio determina que esta deve ser breve, clara e verossímil: "Tres res conuenit habere narrationem, ut breuis, ut dilucida, ut ueri similis sit; quae quoniam fieri oportere scimus, quemadmodum faciamus, cognoscendum est" (Idem, I, 14).

Os preceitos para se conseguir cada uma dessas qualidades na narração são fundamentais para entender como age (ou deveria agir) um narrador. Sobre a brevidade, podem ser destacadas algumas recomendações: evitar retomar um assunto desde uma origem remota em demasia; narrar resumida e não detalhadamente; prosseguir apenas até onde for preciso, mas não até a última consequiência; não fazer transições e nem se afastar daquilo que se começou a expor; deixar de lado tudo aquilo que atrapalha ou que em nada ajuda; e não repetir o que já foi falado. Quanto à clareza, sugere-se: manter a ordem cronológica dos acontecimentos tal como ocorreram ou como poderiam ter ocorrido; não discursar de modo confuso, obscuro, inusitado. Por fim, a respeito da verossimilhança, preceitua-se: falar como o costume, a opinião e a natureza ditam; aterse à duração do tempo, à dignidade dos personagens, aos motivos das decisões e às oportunidades do lugar, para que não se possa refutar afirmando-se que o tempo era curto, que não havia motivo, que o lugar não era propício, ou que as pessoas não podiam fazer ou sofrer tais ações. ${ }^{35}$

\footnotetext{
34 “O gênero de narração que se apóia nas personagens deve ter festividade nas falas, diferenças de ânimo: gravidade e leveza, esperança e medo, desconfiança e desejo, dissimulação e compaixão; variedade de situações: mudanças da sorte, incômodos inesperados, alegrias repentinas, final feliz" (Retórica a Herênio. Tradução de Ana Paula Celestino Faria e Adriana Seabra, op.cit., pp.65-67).

${ }^{35}$ Devido à extrema importância, para nossa pesquisa, das preceptivas sobre as qualidades da narração, citamos, a seguir, o longo trecho no original: "Rem breuiter narrare poterimus, si inde incipiemus narrare, unde necesse erit; et si non ab ultimo initio repetere uolemus; et si summatim, non particulatim narrabimus; et si non ad extremum, sed usque eo, quo opus erit, persequemur; et si transitionibus nullis utemur, et si non deerrabimus ab eo, quod coeperimus exponere; et si exitus rerum ita ponemus, ut ante quoque quae facta sint, scire possint, tametsi nos reticuerimus: quod genus, si dicam me ex prouincia redisse, profectum quoque in prouinciam intellegatur. Et omnino non modo id, quod obest, sed etiam id, quod neque obest neque adiuuat, satius est praeterire. Et ne bis aut saepius idem dicamus, cauendum est; etiam ne quid, nouissime quod diximus, deinceps dicamus, hoc modo:

Athenis Megaram uesperi aduenit Simo:

Ubi aduenit Megaram, insidias fecit uirgini:

Insidias postquam fec it, uim in loco adtulit.

Rem dilucide narrabimus, si ut quicquid primum gestum erit, ita primum exponemus et rerum ac temporum ordinem conseruabimus, ut gestae res erunt aut utpotuisse geri uidebuntur: hic erit considerandum, ne quid perturbate, ne quid contorte, ne quid noue dicamus; ne quam in aliam rem transeamus; ne ab ultimo repetamus; ne longe persequamur; ne quid, quod ad rem pertineat, praetereamus; et si sequemur ea, quae de breuitate praecepta sunt; nam quo breuior, dilucidior et cognitu facilior narratio fiet.
} 
Isso é o que pudemos extrair da Rhetorica ad Herennium; vejamos, agora, o que outro tratado antigo preceitua a respeito da narratio: o De Oratore, de Cícero. ${ }^{36}$ Quanto à dispositio, a obra, acompanhando a opinião predominante entre os retores sobre a ordem das partes do discurso, recomenda que a narração venha logo depois do exórdio e inicia fazendo uma ressalva acerca da brevidade da narratio: esta não deve ser tão breve a ponto de se tornar obscura, já que se for curta em excesso serão tolhidas suas principais "virtudes" - sua graça e sua capacidade persuasiva (sed saepe obest uel maxime in narrando, non solum quod obscuritatem adfert, sed etiam quod eam uirtutem quae narrationis est maxima, ut iucunda et ad persuadendum accommodata sit, tollit). ${ }^{37}$ Em seguida, há interessantes considerações em que se sugere que a narração será mais agradável quando for animada por diversos personagens e "cortada" por diálogos. Além disso, os fatos serão mais "prováveis" quando expostos da exata maneira como ocorreram e serão mais facilmente compreendidos se não houver uma pressa exagerada na exposição:

Sed et festiuitatem habet narratio distincta personis et interpuncta sermonibus, et est et probabilius quod gestum esse dicas, quom quem ad modum actum sit exponas, et multo apertius ad intellegendum [est], si constituitur aliquando ac non ista breuitate percurritur (De Oratore, II, LXXX, 328).

Além da brevidade, a clareza é outra qualidade destacada por Cícero para se evitar a obscuridade. Nesse sentido, o autor é bastante didático: para que a narratio seja clara, deve-se empregar somente palavras usuais, conservar a ordem cronológica dos fatos e não interromper o desenrolar da exposição: "Erit autem perspicua narratio, si uerbis usitatis, si ordine temporum conseruato, si non interrupte narrabitur" (Idem, II, LXXX, 329). Esse cuidado com a narração explica-se na medida em que ela é a base de todas as outras partes do discurso: "quod omnis orationis reliquae fons est narratio" (Idem, II, LXXX, 330).

\footnotetext{
Veri similis narratio erit, si, ut mos, ut opinio, et natura postulat, dicemus; si spatia temporum, personarum dignitates, consiliorum rationes, locorum opportunitates constabunt, ne refelli possit aut temporis parum fuisse, aut causam nullam, aut locum idoneum non fuisse, aut homines ipsos facere aut pati non potuisse (Rhetorica ad Herennium, I, 14-16).

${ }^{36}$ Edição consultada: Cícero. De l'orateur. Trad. Edmond Courbaud. Paris: Les Belles Lettres, 1950.

${ }^{37}$ De Oratore, II, LXXX, 326.
} 
Já em seu Orator, ${ }^{38}$ Cícero não fala quase nada sobre a narratio, apenas mencionando que a exposição dos fatos deve ser breve, verossímil (ou provável) e clara, para que os ouvintes possam compreender do que se trata: "rem breuiter exponere et probaliter et aperte, ut quid agatur intellegi possit" (Orator, XXXIV, 122). Porém, visando a uma "eloquiência admirável", ainda que não sejam considerações específicas sobre a narração, o autor (seguindo os preceitos aristotélicos) tece alguns comentários a respeito do papel do ethos e do pathos no discurso. Assim, afirma que o ethos "acomoda" os temperamentos ou naturezas, os costumes e todas as condutas da vida (ad naturas et ad mores et ad omnem uitae consuetudinem accommodatum ${ }^{39}$ ); enquanto que o pathos, através do qual a eloqüência "triunfa", serve para "perturbar" e "incitar" os ânimos (quo pertubantur animi et concitatur, in quo uno regnat oratio ${ }^{40}$ ). Aquele é afável e agradável, próprio para obter a benevolência; este é veemente, inflamado, impetuoso, e não há meios de resistir a ele (illud superius come, iucundum, ad beneuolentiam conciliandam paratum; hoc uehemens, incensum, incitatum, quo causae eripiuntur; quod cum rapide fertur, sustineri nullo pacto potest ${ }^{41}$ ).

Para que o emprego ético-patético do discurso seja eficaz, Cícero enumera os afetos que devem ser suscitados nos ouvintes: além de provocar a miseratio, o orador deve discursar de modo que o juiz se irrite e se acalme, inveje e favoreça, despreze e admire, odeie e ame, deseje e se entedie, espere e tema, se alegre e se aflija: "Nec uero miseratione solum mens iudicum permouenda est (...) sed est faciendum etiam ut irascatur iudex mitigetur, inuideat faueat, contemnat admiretur, oderit diligat, cupiat taedeat, speret metuat, laetetur doleat” (Idem, XXXVII, 131). Tal enumeração será importante para momentos posteriores da nossa análise.

Por enquanto, passemos ao exame da Epistola ad Pisones de Horácio. ${ }^{42}$ Nessa obra, há alguns preceitos que podem nos ajudar a pensar melhor sobre a narração e a persona que narra ou, nesse caso, o poeta que narra, já que o tratado visa ensinar aqueles que desejam ser poetas.

Desse modo, Horácio inicia sua Arte Poética com aquela conhecida imagem do pintor que, almejando juntar uma cabeça humana a um pescoço de cavalo e

\footnotetext{
${ }^{38}$ Edição utilizada: Cícero. L'orateur: du meilleur genre d'orateurs. Texte établit et traduit par Albert Yon. Paris: Belles Letres, 1964.

${ }^{39}$ Orator, XXXVI, 128.

${ }^{40}$ Idem ibidem.

${ }^{41}$ Idem ibidem.

${ }^{42}$ Edição consultada: Horácio. Arte Poética. Intr., trad. e comentário de R. M. Rosado Fernandes. Lisboa: LCE, s/d (colecção bilíngüe).
} 
colocando variadas plumas em membros de diferentes animais, obtém, como obra final, um torpe e negro peixe, em vez de uma bela mulher. Com base nesse exemplo, Horácio recomenda aos poetas e aos pintores que façam tudo o que quiserem, contanto que o façam com simplicidade e unidade: "Denique sit quod uis, simplex dumtaxat et unum" (Arte Poética, v.23). Posteriormente, veremos os esforços do narrador da Constante Florinda para manter a unidade e a simplicidade do enredo principal, entrecortado por uma infinidade de histórias singulares.

Prosseguindo na análise da Epistola ad Pisones, o autor afirma que não basta que os poemas sejam belos, mas que sejam “doces” e transportem o ânimo do auditório para onde quiserem: "Non satis est pulchra esse poemata; dulcia sunto / et, quocumque uolent, animum auditoris agunto" (Idem, vv.99-100). Para fazer um poema belo, doce e capaz de persuadir o auditório, o scriptor tem que seguir a "fama" (fama) ou "fingir" (fingire) caracteres convenientes (Idem, vv.120-121); o poeta deve, por exemplo, ressaltar sempre os costumes (mores) e características de cada idade, isto é, o velho não pode ser representado como um jovem, nem o homem como um garoto: "Ne forte seniles / mandentur iuueni partes pueroque uiriles; / sempre in adiunctis morabitur aptis" (Idem, vv.176-178).

Na Arte Poética de Horácio, um assunto (do qual trataremos outras vezes neste trabalho) muito relevante para se refletir sobre o ato de narrar diz respeito à recomendação de que os poetas, em suas composições, devem buscar unir o deleite à utilidade, "dizendo" coisas belas e proveitosas para a vida : "Aut prodesse uolunt aut delectare poetae / aut simul et iucunda et idonea dicere uitae" (Idem, vv.333-334). Para deleitar e ensinar, o scriptor, quando preceituar algo, há de ser breve, deixando de lado tudo o que for supérfluo, com o intuito de que os ânimos dos ouvintes apreendam as "lições" com maior facilidade e rapidez; além disso, as ficções, para causarem prazer, devem ser verossímeis (Idem, vv.335-338). Enfim, os poetas que assim agirem, mesclando o útil ao agradável, merecerão todos os louvores: "Omne tulit punctum qui miscuit utile dulci, / lectorem delectando pariterque monendo" (Idem, vv.344-343).

Para encerrar, merece destaque o conhecido trecho do ut pictura poesis horaciano, já que é um tema essencial tanto para os autores antigos como para os seiscentistas (o que ficará nítido quando nos voltarmos para o tratado Poesia e pintura, ou, Pintura e poesia, de Manuel Pires de Almeida):

Vt pictura poesis; erit quae, si proprius stes, 
te capiat magis, et quaedam, si longius abstes;

haec amat obscurum, uolet haec sub luce uideri,

iudicis argutum quae non formidat acumen;

haec placuit semel, haec deciens repetita placebit. ${ }^{43}$

Porém, é preciso ressaltar, como o faz João Adolfo Hansen, que, nesses famosos versos, Horácio não afirma que a pintura é poesia ou que qualquer uma delas possa ser convertida na outra; o que há é uma comparação, atestada pela partícula $u t$ : "uma relação de homologia dos procedimentos retóricos ordenadores dos efeitos de estilo, não uma relação de identidade ou equivalência das substâncias da expressão plástica e discursiva”. Como explica o mesmo Hansen:

Quando fazem a comparação, os versos propõem que há um modo específico de formulação para cada gênero e, logo, da sua apreciação, o que imediatamente implica que o ut pictura poesis é uma doutrina genérica da verossimilhança necessária em cada obra, segundo sua invenção, disposição e elocução, para que possa cumprir as três grandes funções retóricas de docere, delectare e movere, representadas nos versos citados. ${ }^{44}$

Portanto, o narrador, para não ter por que recear o olhar arguto de seus juízes (os leitores), há de ser como um pintor perspicaz, que saiba usar convenientemente a distância (perto/longe), a claridade (clareza/obscuridade) e a freqüência (uma vez/várias vezes), para compor uma obra que seja, ao mesmo tempo, útil e bela.

Entre os tratados antigos consultados, o que dedica o mais longo e completo estudo sobre a narratio é a Institutio Oratoria, de Quintiliano. ${ }^{45} \mathrm{O}$ extenso capítulo II, do Livro IV, é todo destinado ao tema. Vejamos, então, algumas considerações do

\footnotetext{
${ }^{43}$ Idem, vv.361-365. Na tradução de R. M. Rosado Fernandes, o mesmo trecho aparece da seguinte maneira: "Como a pintura é a poesia: coisas há que de perto mais te agradam e outras, se a distância estiveres. Esta quer ser vista na obscuridade e aquela à viva luz, por não recear o olhar penetrante dos seus críticos; esta, só uma vez agradou, aquela, dez vezes vista, sempre agradará" (Arte Poética, op.cit., pp.109-111).

44 "Ut Pictura Poesis e Verossimilhança na Doutrina do Conceito no século XVII". In: Para Segismundo Spina: Língua, Filologia, Literatura. São Paulo: Edusp; Iluminuras, 1995, pp.204-205.

${ }^{45}$ Edição utilizada: Quintiliano. Institution Oratoire. Trad. Henri Bornecque. Paris: Garnier Frères, 1954.
} 
autor. ${ }^{46}$ Quanto à definição do termo, primeiro afirma que a narração visa a indicar o assunto (res) a respeito do qual o juiz deverá pronunciar-se: "Maxime naturale est, et fieri frequentissime debet, ut, praeparato per haec, quae supra dicta sunt, iudice, res, de qua pronuntiaturus est, indicetur: ea est narratio" (Inst. Orat., IV, II, 1). Posteriormente, elaborando um pouco mais a idéia, esclarece que a narratio não serve apenas para "informar" o juiz sobre o caso, mas também para fazer com que ele "concorde" com o orador: "Neque enim narratio in hoc reperta est, ut tantum cognoscat iudex, sed aliquanto magis, ut consentiat" (Idem, IV, II, 21). Por fim, aproveitando-se do que já havia dito, Quintiliano dá uma definição mais completa, em que ressalta a utilidade da narração, isto é, seu caráter persuasivo: "Narratio est rei factae aut ut factae utilis ad persuadendum expositio, vel - ut Apollodorus finit - oratio docens auditorem quid in controversia sit" (Idem, IV, II, 31).

O autor também apresenta algumas classificações e divisões referentes ao termo. A narratio não é uma mera discussão dos fatos, mas da pessoa, do lugar, do tempo e das causas. Algumas narrações são perfeitas, outras imperfeitas; podem versar sobre tempos passados, presentes ou futuros (Idem, IV, II, 2-3). Quintiliano imputa tais classificações a outros retores e parece não as considerar importantes, podendo-se depreender de seu texto que "solo hay un género de narratio, la forense, que puede dividirse en dos especies. La primera es aquella que expone el hecho, la segunda la que expone las circunstancias que rodean al hecho". 47

No entanto, mais relevante para nosso trabalho são os comentários sobre as qualidades da narração, sendo que esse ponto é o mais amplamente abordado pelo autor. Na Institutio Oratoria, as qualidades da narratio são relacionadas com os graus de defesa da causa: a narração ou é favorável à causa de quem discursa ou aos adversários, ou, ainda, é mista, em parte favorável a quem discursa, em parte ao adversário (Idem, IV, II, 33). ${ }^{48}$ Desse modo, esses três tipos de narratio correspondem a três dos genera causarum da retórica antiga: ${ }^{49}$ o genus honestum, o genus admirabile e o genus anceps. O primeiro, de acordo com a explicação de Lausberg, é "el grado de defendibilidad de una causa que responde total y plenamente al sentimiento jurídico (o generalizando por encima del campo jurídico: a la conciencia general de los valores y de la verdad) del

\footnotetext{
${ }^{46}$ No caso específico das considerações de Quintiliano sobre a narratio, nos apoiaremos, em grande parte, na excelente análise de Elena Artaza: El ars narrandi en el siglo XVI español. Teoria y practica, op.cit., pp.60-91.

${ }^{4}$ Idem, p.67.

48 Idem, p.71.

${ }^{49}$ Cf. Lausberg, H., Manual de Retórica Lietraria, op.cit., p.112.
} 
público". ${ }^{50}$ Já o genus admirabile é "el grado de defendibilidad de una causa que choca contra el sentimiento jurídico (o generalizando por encima dela campo jurídico: contra la conciencia de los valores y de la verdad) del público". ${ }^{51}$ Por fim, o genus anceps é "el grado de defendibilidad de una causa que provoca en el sentimiento jurídico (o genreralizando por encima del campo jurídico: en la conciencia general de los valores y de la verdad) del público un serio problema respecto a la defendibilidad jurídica (o general)". 52

Pois bem. De acordo com Quintiliano, as narrações que estão incluídas no genus honestum devem possuir, além das três qualidades modelares (brevidade, clareza e verossimilhança), a magnificentia, a iucunditas e a euidentia. $\mathrm{O}$ autor trata, em primeiro lugar, da clareza. Esta é fundamental tanto para a matéria do discurso (res) como para as palavras (uerba). Uma exposição clara é aquela em que há um emprego de palavras próprias, plenas de significado, não vulgares, nem rebuscadas ou distantes do uso corrente; uma nítida diferenciação das coisas, das pessoas, dos tempos, dos lugares e das causas; e uma capacidade de fazer com que o juiz entenda o que se diz da maneira mais fácil possível.

Erit autem narratio aperta ac dilucida, si fuerit primum exposita uerbis propiis et significantibus et non sordidis quidem, nom tamen exquisitis et $\mathrm{ab}$ usu remotis, tum distincta rebus, personis, temporibus, locis, causis, ipsa etiam pronuntiatione in hoc accommodata, ut iudex quae dicentur facilime accipiat (Idem, IV, II, 36).

Quanto à brevidade, Quintiliano faz três recomendações para se obter uma narratio breuis: narrar somente os fatos pertinentes à causa, ou seja, aqueles que interessam ao juiz; não narrar nada alheio à causa; e silenciar tudo aquilo que seja inútil à causa ou que não ajude no conhecimento dos fatos.

Breuis erit narratio, ante omnia, si inde coeperimus rem exponere, unde ad iudicem pertinet; deinde, si nihil extra causam dixerimus; tum etiam, si reciderimus omnia, quibus sublatis neque cognitioni quicquam neque utilitati detrahatur (Idem, IV, II, 40).

\footnotetext{
${ }^{50}$ Idem, ibidem.

${ }^{51}$ Idem, p. 113.

${ }^{52}$ Idem, ibidem.
} 
Essencial para reflexões posteriores deste trabalho é o que preceitua o autor, ainda tratando da breuitas, a respeito das narrações longas por natureza. Nestas deve-se ter um cuidado especial para se evitar o tédio (taedium). Eis algumas sugestões para que a narratio seja menos extensa e não deixe os ouvintes "entediados": relegar alguns aspectos para serem expostos apenas na confirmatio; prescindir de alguns elementos não tão relevantes para a causa; fazer uma divisio (assim parecerá que são várias narrações curtas em vez uma longa); interromper o relato com breves apelações (dessa forma, o juiz se sentirá reconfortado com o término da primeira parte e se preparará para o início de uma nova); e, sendo muitos os fatos narrados, será bastante útil fazer um resumo, na parte final, para relembrar tudo aquilo que foi dito (Idem, IV, II, 47-51).

Sobre a verossimilhança ou "credibilidade" da narratio, Quintiliano aponta os seguintes recursos para atingi-la: omitir tudo que seja contrário à natureza das coisas; expor as causas e motivos dos fatos, assim como onde e quando ocorreram; semear os pontos que serão referidos na argumentação, ou seja, fazer uma preparação (praeparatio), de preferência imperceptível para os ouvintes, do que será discutido mais à frente no discurso (Idem, IV, II, 52-56); produzir uma verdadeira imagem dos fatos para que o ouvinte possa "ver" diante de si o fato presente (Multum confert adiecta ueris credibilis rerum imago, quae uelut in rem praesentem perducere audientis uidentur ${ }^{53}$ ); por fim, a credibilidade da exposição também decorre da "autoridade" do narrador, obtida tanto através de seu "comportamento exemplar" como de seu "estilo" de discurso, já que quanto mais grave e digno for, mais peso terão suas afirmações ( $N e$ illud quidem praeteribo, quantam adferat fidem expositioni narrantis auctoritas, quam mereri debemus ante omnia quidem uita, sed et ipso genere orationis; quod quo fuerit grauius ac sanctius, hoc plus habeat necesse est in adfirmando ponderis ${ }^{54}$ ).

Depois de abordar essas três qualidades, Quintiliano menciona outras que tenham alguma relevância para o genus honestum. A primeira mencionada, a magnificentia, tem um valor reduzido, posto que, segundo o autor, não é tão próprio da narração discorrer com magnificência quanto falar em tom de comiseração, de odiosidade, de gravidade, de doçura e de urbanidade: "Quare non magis proprium narrationis est magnifice dicere quam miserabiliter, inuidiose, grauiter, dulciter, urbane" (Idem, IV, II, 62). No que se refere à segunda, a iucunditas, afirma que não é

\footnotetext{
${ }^{53}$ Inst. Orat., IV, II, 123.

${ }^{54}$ Idem, IV, II, 125.
} 
exclusividade da narratio ter um caráter agradável e prazenteiro, mas sim de todo o discurso. Finalmente, a euidentia é uma característica que se subordina à claridade e determina que não basta dizer algo verdadeiro, senão também ostentá-lo de algum modo: "euidentia in narratione, quantum ego intellego, est quidem magna uitus, cum quid ueri non dicendum, sed quodmmodo etiam ostendendum est” (Idem, IV, II, 64).

Com relação às causas dos gêneros admirabile e anceps, são citadas outras qualidades da narração. Visando conservar a clareza e brevidade da narratio, Quintiliano recrimina o emprego de digressões: "Vt sit expositio perspicua et breuis, nihil quidem tam raropoterit habere rationemquam excursio" (Idem, IV, II, 104). Além disso, recomenda que, durante a exposição, o orador dirija-se a outra pessoa que não seja o juiz e que também faça uso de prosopopéias, pois assim o discurso fica dotado de maior força de convencimento e torna-se mais breve (Idem, IV, II, 106). Um outro preceito do autor indica que não é conveniente argumentar na narração, ainda que, ocasionalmente, se possa introduzir uma breve defesa e uma rápida justificativa dos fatos (Idem, IV, II, 108-109). Por último, vale a pena destacar que, assim como Aristóteles, Quintiliano defende a moção dos afetos na narratio. Embora o autor da Institutio Oratoria considere, por razões de brevidade, que os afetos não cabem durante muito tempo nem com tanta força na narração, não deixa de ver nesta um momento fundamental em que o orador não deve apenas docere, mas também mouere, para que, no epílogo, o ânimo do juiz já esteja tomado pela ira ou pela piedade:

\begin{abstract}
Quo magis miror eos, qui non putant utendum in narratione adfectibus. Qui si hoc dicunt "non diu neque ut in epilogo", mecum sentiunt; effugiendae sunt enim morae. Ceterum cur ego iudicem nolim, dum doceo, etiam mouere? Cur, quod in summa sum actionis petiturus, non in primo statim rerum ingressu, si fieri potest, consequar cum praesertim etiam in probationibus faciliorem sim animum eius habiturus, occupatum uel ira uel miseratione (Idem, IV, II, 111-112). ${ }^{55}$
\end{abstract}

\footnotetext{
55 "Por lo que tanto más me admiro de aquellos maestros de Retórica, que piensan que en la narración no hay que emplear la provocación de los afectos. Si con esto quieren decir: "no por mucho tiempo ni como se hace en el Epílogo', están de acuerdo conmigo, pues hay que evitar deternerse ahí demasiado. Pero ¿por qué no voy a querer yo, mientras estoy informado, conmover incluso al juez? ¿Por qué lo que trataré de conseguir en el punto culminante de mi discurso, no lo voy a buscar inmediatamente con ahínco en el primer paso a los acontecimientos, si es esto posible? ¿Sobre todo cuando en medio de las demonstraciones me sea dado tener su ánimo más inclinado, antes previnido por la ira o la misericordia?" (Institutionis oratoriae: libri XII. Sobre la formación del orador: doce libros. Obra completa. Tomo II. Traducción y comentarios de Alfonso Ortega Carmona. Salamanca: Universidad Pontificia de Salamanca, 1999, pp.85-87).
} 
Quintiliano trata ainda de uma outra relevante questão relacionada à narratio: o ornato. Para ele, toda parte do discurso "debe adornarse con gracia y belleza, aunque siempre teniendo presente la adecuación entre res y verba, es decir, entre cosas y palabras o temas del discurso y elocución". 56 Nos assuntos menores (genus humile), recomenda que o ornato, através das palavras, da composição e do uso de figuras, seja moderado e muito adstrito ao assunto ou matéria; porém, tal adorno há de ser sempre buscado, uma vez que o que se ouve com prazer resulta mais crível (Idem, IV, II, 117119). Já nos assuntos maiores ou mais importantes, é preciso ter cuidado com o tom ao se dizer algo, narrando-se, por exemplo, as coisas tristes num tom compassivo; ainda para tais matérias, é permitido e aconselhável o emprego de ditos sentenciosos, com o intuito de aliviar a fatiga do juiz (Idem, IV, II, 120-121).

Para encerrar a exposição de alguns pontos da preceptiva de Quintiliano, observemos o que o autor preceitua a respeito do início e do fim que deve ter uma narração. Para o começo, sugere que pode partir-se, às vezes, da pessoa (apresentando-a favoravelmente se for da parte do orador ou desfavoravelmente se for da parte contrária) e outras vezes do fato. Quando se inicia pela pessoa e for conveniente, é possível partir de fatos acidentais que a cercam, como, por exemplo, referir-se à sua ascendência (Idem, IV, II, 129-131). Sobre o final da narratio, Quintiliano somente assinala que não há unanimidade entre os retores e destaca que alguns preferem que a exposição se prolongue até a primeira das questões, afirmando que tal prolongamento sempre pode ser feito pelo demandante e não sempre pelo defensor (Idem, IV, II, 132).

Dentre os autores antigos, foram essas as principais contribuições que pudemos destacar para que pensemos na narração e, conseqüentemente, na figura do narrador. Entretanto, é necessário verificar também como se discute a questão nas obras publicadas em momentos mais próximos àqueles em que escreveram os autores seiscentistas. Por isso, passaremos a expor como alguns textos dos séculos XVI, XVII e XVIII abordaram o tema.

Começaremos referindo dois tratados que, no século XVI, visaram à constituição do perfeito cortesão. Foram esses os textos escolhidos, pois serviram como modelos de uma obra portuguesa do início do século XVII: a Corte na aldeia e noites de inverno, de Francisco Rodrigues Lobo. Dessa forma, o mais importante tratado do

\footnotetext{
${ }^{56}$ Artaza, E. El ars narrandi en el siglo XVI español, op.cit., p.83.
} 
gênero foi $O$ cortesão (1528), de Baldassare Castiglione. ${ }^{57}$ No livro I, há um trecho em que se resume a "arte retórica" a ser utilizada pelo homem de corte:

- Receio - disse então o senhor Morello - que se esse cortesão falar com tanta elegância e gravidade, dentre nós haverá quem o não entenda. - Ao contrário, todos irão compreendê-lo, - respondeu o conde - porque a facilidade não impede a elegância. Não quero que ele fale sempre gravemente, mas também de coisas agradáveis, de jogos, de motejos e de ironias conforme o momento; e de tudo falará sensatamente, com desenvoltura, abundância e clareza; e tampouco há de mostrar em nenhum aspecto vaidade ou tolice pueril. E quando falar de coisas obscuras ou difíceis, pretendo que, através de palavras e sentenças bem distintas, explique com sutileza suas intenções, tornando cada ambigüidade clara e lhana, de um modo diligente e sem perturbação. Igualmente, onde for preciso, deverá falar com dignidade e veemência, concitando aqueles afetos que trazemos no âmago, acendendo-os ou movimentando-os conforme a necessidade; às vezes, com a simplicidade daquele candor que faz parecer que a própria natureza fale, enternecê-los e quase inebriá-los de doçura, e com tal facilidade que aquele que ouvir considere que ele próprio, com pouquíssimo trabalho, poderia atingir aquele nível, mas, dele se ache bem distante quando o experimenta. Gostaria que o nosso cortesão falasse e escrevesse de tal maneira; e não somente juntasse palavras esplêndidas e elegantes de todas as regiões da Itália, mas eu também apreciaria que usasse por vezes um daqueles termos franceses e espanhóis, que já são aceitos pelo nosso uso. Porém, não me desagradaria que, caso fosse preciso, dissesse primor, accertare, avventurare, ripassare una persona con ragionamento, querendo com isso dizer conhecê-la e freqüentá-la para melhor entendê-la; dissesse um cavalier senza rimproccio, attilato, creato d'un principe e outros termos semelhantes, desde que esperasse ser compreendido. Em certas ocasiões, gostaria que tomasse algumas palavras em sentido figurado; e, transportando-as com critério, como se as enxertasse tal um galho de árvore em tronco mais apropriado para torná-las mais graciosas e elegantes, e como para tornar mais palpáveis as coisas aos olhos de

${ }^{57}$ Edição consultada: $O$ cortesão. Tradução Carlos Nilson Moulin Louzada. São Paulo: Martins Fontes, 1997. 
quem ouve ou lê. E também gostaria que não temesse criar novas palavras e novas maneiras de dizer, deduzindo-as com beleza dos latinos, como já os latinos as deduziam dos gregos. ${ }^{58}$

Essa longa citação se justifica na medida em que nela estão os preceitos primordiais d' Il libro del cortegiano ${ }^{59}$ sobre os modos mais adequados e eficientes de se falar e de se escrever, apresentando uma síntese, adaptada aos intentos do Libro, da preceptiva das retóricas antigas. Vale a pena determo-nos no trecho para entendermos como, segundo a obra de Castiglione, um homem de corte do século XVI deveria falar ou escrever; prescrições essas que serão úteis para configurarmos nosso narrador seiscentista.

A discussão inicia-se questionando se a eleganzia e gravità na fala impediriam a facilità na compreensão do que é dito. Para que a "facilidade" não fique comprometida, recomenda-se mesclar a gravidade a coisas mais agradáveis e divertidas, tornando o discurso mais variado, talvez para evitar o taedium tão recriminado por Quintiliano. E sobre todos os assuntos deve-se falar sensatamente e con prontezza e copia non confusa, ou seja, daquelas três principais qualidades da narração que verificamos nos tratados retóricos antigos, podemos identificar a verossimilhança ou credibilidade na "sensatez", a clareza na "cópia não confusa", mas não se percebe qualquer menção à brevidade; ao contrário, nota-se uma certa incitação à "abundância". A clareza parece ser a qualidade que merece maior atenção, na medida em que se insiste no fato de que, quando for preciso discorrer a respeito de coisas obscuras ou difíceis (cosa oscura o difficile), há de ser feito de modo que as intenções fiquem explícitas e que toda possível ambiguità torne-se chiara e piana.

Como observamos na exposição dos preceitos dos autores antigos, a narração, desde Aristóteles, tem a incumbência de mover os afetos do auditório. N' O cortesão, também fica evidente que o pathos é essencial para o discurso, cabendo ao gentilhomem falar con dignità e veemenzia, com o objetivo de concitar quegli affetti che hanno in sé gli animi nostri, movendo-os conforme a necessidade (moverli secondo il bisogno). Assim, é nítido que Castiglione considera os afetos instrumentos fundamentais de persuasão, que devem ser utilizados em favor da causa. Ressalta, porém, que esse emprego há de ser feito com a simplicità daquele candore, que se

\footnotetext{
${ }^{58}$ Idem, I, XXXIV, pp.53-54.

${ }^{59}$ Para conferir alguns termos no texto original, consultamos a seguinte edição: Il libro del cortegiano. A cura di Giulio Preti. Torino: G. Einaudi, 1960.
} 
assemelhe à própria fala da natureza, enternecendo e inebriando com dolcezza, e com tal facilità que os ouvintes se julguem aptos a discorrer da mesma forma, embora não o consigam. Não há como deixar de relacionar esse trecho ao conhecido conceito de sprezzatura, isto é, a faculdade ou facilidade espontânea que o cortesão deve mostrar ao fazer algo, dando a impressão de uma superioridade sem esforço.

$\mathrm{Na}$ parte final da citação, trata-se da elocutio do discurso. Desse modo, permite-se que o cortesão use não somente palavras italianas splendide ed eleganti, mas também termos franceses e espanhóis correntes na Itália, além de neologismos. No entanto, o que é de suma importância para o nosso estudo é a recomendação de que se empregue algumas palavras em sentido figurado (in altra significazione che la lor propria), para que, deixando-as piú vaghe e belle, torne as coisas mais visíveis e palpáveis, com o intuito de deleitar quem ouve ou lê (con diletto di chi ode o legge). Enfim, o discurso é como uma pintura ou escultura (não nos esqueçamos do ut pictura poesis horaciano), que, para delectare, tem nas palavras figuradas sua principal matériaprima.

Prosseguindo no mesmo gênero e no mesmo século, vejamos o que um outro tratado quinhentista preceitua acerca da maneira de se narrar uma história. No Galateo (1558), de Giovanni Della Casa ${ }^{60}$, recomenda-se o seguinte para a "fala longa e continuada":

requer ser ordenada e bem expressa, apresentando os modos, os costumes, os atos e os usos daqueles de quem se fala, de modo que o ouvinte tenha a impressão não de ouvir contar, mas de ver com os próprios olhos as ações que narras (...), e, para fazer isso, é necessário ter o acidente, a novela ou a história que tenhas para contar, bem elaborada na mente, e as palavras prontas e preparadas. ${ }^{61}$

Portanto, nesse primeiro trecho mencionado nota-se que o texto de Della Casa se aproxima d' $O$ cortesão e do preceito das retóricas e poéticas antigas de que, quando se narre algo, é preciso fazê-lo de forma que as coisas possam ser vistas e não apenas ouvidas. Para tanto, a narração deve ser verossímil, representando, cuidadosamente, os

\footnotetext{
${ }^{60}$ Galateo, ou, Dos costumes. Tradução Edileine Vieira Machado. São Paulo: Martins Fontes, 1999.

${ }^{61}$ Idem, XXI, p.54.
} 
modi, usanze, atti e costumi ${ }^{62}$ da persona de quem se fala, e que o accidente, novella ou istoria esteja prefigurado nella mente e le parole pronte et apparecchiate, evitando, assim, uma fala titubeante e entrecortada.

Quanto às palavras, há várias recomendações no Galateo. Em primeiro lugar, hão de ser claras e belas: "As palavras, tanto nas falas longas como nas outras formas de argumentação, requerem ser claras para que todos da companhia possam entendê-las facilmente, e ainda belas quanto ao som e quanto ao significado",63, devendo-se fugir, sempre, dos arcaísmos. Além disso, as palavras (le parole) têm que ser "o mais possível apropriadas àquilo que se quer demonstrar, e o menos possível comum a outras coisas, de tal modo que as próprias coisas pareçam estar diante de nós, sendo mostradas não com as palavras, mas com o dedo". ${ }^{64}$ Desse modo, mais uma vez a "imagem" do que é dito deve ser buscada ao se narrar algo; nesse caso, através da conformidade entre le parole e le cose. Por fim, pode-se destacar que Della Casa sugere que na ordenação das palavras haja clareza, evitando-se a confusão que alguns fazem ao falar, por simples afetação (per leggiadria): "As palavras requerem ser ordenadas segundo o que pede o uso da fala comum, e não confusas e embaraçadas aqui e ali como muitos têm o costume de fazer por afetação". 65

Em fins do século XVI, foram publicados os Discorsi del poema eroico (1594), de Torquato Tasso. ${ }^{66}$ Destaquemos algumas discussões presentes nesse tratado, que, como veremos, foi um importante modelo para os autores seiscentistas como, por exemplo, Manuel Pires de Almeida. Segundo Tasso, a poesia é uma "imitazione de l'azioni umane, fatta per ammaestramento de la vita", 67 que tem um fim duplo: delectare e docere. Nas palavras do autor, a poesia "a fine di giovare dilettando". ${ }^{68}$ Mas o que lhe interessa, nesse tratado em particular, é o poema heróico, que é assim definido: "è una imitazione d'azione illustre, grande e perfetta, fatta narrando con altíssimo verso, a fine di giovar dilettando, cioè a fine che il diletto sia cagione ch'altri leggendo piú volentieri non escluda il giovamento". ${ }^{69}$ Ensinar deleitando, no entanto, é

\footnotetext{
${ }^{62}$ Para conferir alguns termos no texto original, consultamos a seguinte edição: Galateo. Introduzione e note di Saverio Orlando. Milano: Garzanti libri, 1995.

${ }^{63}$ Galateo, ou, Dos costumes, op.cit., XXII, p.57.

${ }^{64}$ Idem, XXII, p.59.

${ }^{65}$ Idem, XXIII, p.69.

${ }^{66}$ Discorsi del Poema Eroico. In: Prose. Milano: Rizzoli, 1935, pp.315-539. Como sabemos, esses Discursos são uma versão ampliada dos Discorsi dell'arte poetica e in particolare sopra il poema eroico (Veneza, 1587).

${ }^{67}$ Discorsi del Poema Eroico, I, op.cit., p.326.

${ }^{68}$ Idem, I, p.328.

${ }^{69}$ Idem, I, p.331.
} 
a finalidade de toda poesia. $\mathrm{O}$ que é peculiar à epopéia é ter como objetivo primordial o "mover maravilha". Por isso, Tasso aperfeiçoa aquela definição:

Ma il poeta epico non ha altro fine; ed a l'incontro muove compassione per muover maraviglia; però la muove molto maggiore e piú spesso. Diremo dunque che il poema eroico sia imitazione d'azione illustre, grande e perfetta, fatta, narrando con altissimo verso, a fine di muover gli animi con la maraviglia, e di giovare in questa guisa. ${ }^{70}$

No Livro II, é tratada a elezione da matéria do poema heróico. O poeta, ao eleger a matéria, deve sempre visar à fede e autoritá das coisas, porque, sendo um imtador, há de imitar o que é verdadeiro e não aquilo que é falso. Para Tasso, o poeta é "amigo da verdade", o que não impede que seu poema seja "novo", pois a "novidade" está muito mais na forma do que na matéria. ${ }^{71}$ Porém, como conciliar a finalidade do poema épico, a maravilha, com essa necessidade de verossimilhança? Quanto a esse problema, afirma o autor: "Può esser dunque una medesima azione e maravigliosa e verisimile: maravigliosa, riguardandola in se stessa e circonscritta dentro ai termini naturali; verisimile, considerandola divisa da questi termini ne la sua cagione, la quale è una virtú sopranaturale, possente, ed usata a far simili maraviglie". ${ }^{72}$

Sobre a narração, em especial, Tasso segue a Poética de Aristóteles: as coisas imitadas são as ações; o modo é o narrar ou o representar. "Narrare si dice quello, nel quale appare la persona del poeta; rappresentare, ove è occulta quella del poeta, e si

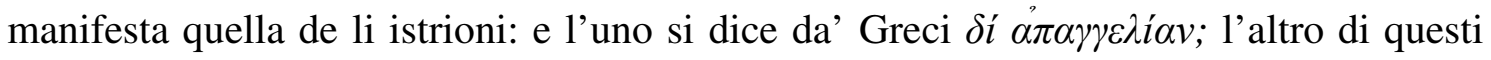
modi è detto drammatico". ${ }^{73}$ Assim, o Épico narra e o Trágico representa.

Enfim, como resume Tasso, as condições que o judicioso poeta deve considerar ao buscar a matéria do seu poema são: a autoridade da história, a verdade da religião, a licença do fingir, a qualidade de "tempi accomodati" e a grandeza dos acontecimentos.

O livro III refere-se à disposição e à forma do poema heróico. De fundamental relevância para a epopéia em prosa seiscentista, é a discussão acerca da unidade, grandeza e variedade da fábula. Para Tasso, a fábula tem que ser inteira ou de

\footnotetext{
${ }^{70}$ Idem, I, p.334.

${ }^{71}$ Idem, II, p.356.

${ }^{72}$ Idem, II, p.362.

${ }^{73}$ Idem, II, p.366.
} 
conveniente grandeza e una; ela será perfeita se tiver princípio (il principio), meio (il mezzo) e fim (l'ultimo). A grandeza é necessária na poesia épica,

ma si come l'occhio è dritto giudice de la grandezza del corpo, cosí il giudicare la quantitá de' poemi s'appartiene a la memoria. Grande dunque sará convenevolmente quella poesia in cui la memoria non si perda né si smarrisca, ma, tutta unitamente comprendendola, possa considerare come l'una cosa con l'altra sia congiunta e da l'altra dependente. $^{74}$

O poema perfeito deve ter sempre uma única ação; se houver mais de uma, tratam-se, na verdade, de vários poemas imperfeitos. Mesmo para os romanzi, Tasso defende a unidade da ação. Embora a variedade proporcione deleite, é preciso aprender com o "magistério de Deus" e imitar na poesia a variedade-unidade do próprio mundo (vale a pena citar o longo trecho que será, explicitamente, reutilizado por Manuel Pires de Almeida):

sì come in questo mirabile magisterio di Dio, che mondo si chiama, e '1 cielo si vede sparso o distinto di tanta varietá di stelle, e, discendendo poi giú di regione in regione, l'aria e 'l mare pieni di uccelli e di pesci, e la terra albergatrice di tanti animali cosí feroci, come mansueti, ne la quale e ruscelli e fonti e laghi e prati e campagne e selve e monti sogliamo rimirare, e qui frutti e fiori, lá ghiacci e nevi, qui abitazioni e culture, lá solitudine ed orrori; con tutto ciò uno è il mondo che tante e sí diverse cose nel suo grembo rinchiude, una la forma e l'essenza sua, uno il nodo dal quale sono le sue parti con discorde concordia insieme congiunte e collegate; e, non mancando nulla in lui, nulla però vi è che non serva a la necessità o a l'ornamento: cosí parimente giudico che da eccelente poeta (il quale non per altro è detto divino, se non perché, al supremo artefice ne le sue operazioni assomigliandosi, de la sua divinità viene a partecipare) un poema formar si possa, nel quale, quasi in un picciolo mondo qui si leggano ordinanze di eserciti, qui battaglie terrestri e navali, qui espugnazioni di città, scaramucce e duelli, qui giostre, qui descrizioni di fame e di sete, qui tempeste, qui incendi, qui

\footnotetext{
${ }^{74}$ Idem, III, p.395.
} 
prodigi; lá si trovino concili celesti ed infernali, lá si veggiano sedizioni, lá discordie, lá errori, lá venture, lá incanti, lá opere di crudeltá, di audacia, di cortesia, di generositá, lá avvenimenti d'amore, or felici, or infelici, or lieti, or compassionevoli; ma che nondimeno uno sia il poema che tanta varietá di materie contegna, una la forma e l'anima sua, e che tutte queste cose sieno di maniera composte che l'una l'altra riguardi, l'una a l'altra corrisponda, l'una da l'altra o necessariamente o verisimilmente dependa, sí che una sola parte o tolta via, o mutata di sito, il tutto si distrugga. ${ }^{75}$

A variedade ou a diversidade da fábula pode ser enriquecida pelos episódios. Mas estes devem ser introduzidos segundo o verossímil ou o necessário, isto é, para que a favola episodica ajude a diversificar a principal e, desse modo, aumente o deleite do poema, ela tem que se relacionar, verossímil ou necessariamente, com a ação central, surgindo como uma conseqüência natural dos acontecimentos narrados. Além do episódio, outra noção importante para a narração é a de decoro. De acordo com Tasso, há um decoro geral e outro particular, assim definidos:

Questo decoro è doppio; perché l'uno è generale, il quale risplende in ogni azione onesta; l'altro è a questo soggetto, il qual si conosce ne le parti de l'onestá: e ciò conosciamo esser vero, considerando quel decoro c'hanno osservatoi poeti, i quali allora sono piú lodati, ch'osservano quel ch'è conveniente. ${ }^{76}$

É conveniente, por exemplo, que toda a ação tenha algum agente, mais ainda, que esse agente tenha qualquer qualidade, boa ou má, e digna de louvor ou de repreensão, "perché la persona accresce autoritá a l'azione". ${ }^{77}$ Estendendo essa idéia, podemos dizer que o ethos do narrador da Constante Florinda é que dará autoridade à sua "ação", que nada mais é do que seu próprio discurso.

Nos três últimos livros dos Discorsi del poema eroico, são abordados temas da elocução poética. São duas as principais qualidades da elocução: a clareza (chiarezza) e a convenevole altezza, ou seja, o parlare não deve ser nem humilde nem muito inflado.

\footnotetext{
${ }^{75}$ Idem, III, p.412.

${ }^{76}$ Idem, III, p.429.

${ }^{77}$ Idem, III, p.442.
} 
Conforme Tasso, "lo stile eroico adunque non è lontano da la gravitá del tragico, né da la vaghezza del lirico; ma avanza l'un e l'altro ne lo splendore d'una meravigliosa maestá". ${ }^{78}$ Além disso, o autor também defende a brevidade (brevitá) no parlare, pois este, dilatando-se, perde sua graça (grazia).

Para encerrar, vale a pena ressaltar que Tasso já fala dos "conceitos", que serão um assunto constante nas discussões seiscentistas. $O$ autor, recorrendo a Aristóteles (em particular, ao livro III do De Anima), afirma que as palavras (le parole) são imagens dos conceitos (concetti), os quais estão no nosso ânimo (animo), e os conceitos são imagens das coisas que estão fora do intelecto: por isso, as palavras são imagens das imagens. Enfim, "possiamo dunque concludere che le parole seguono i concetti, e 'l verso parimente". 79

Devido à importância dos "conceitos" nos séculos XVI e XVII, vale a pena recordar o que diz a principal fonte antiga do assunto: Aristóteles. Assim, lemos no De Anima que: "Para a alma capaz de pensar, as imagens subsistem como sensações percebidas. E, quando se afirma algo bom ou nega-se algo ruim, evita-o ou persegue-o. Por isso, a alma jamais pensa sem imagem" (III, 7, 431a8). Nesse sentido, conclui Aristóteles: "Em suma, o intelecto em ato é os seus objetos" (III, 7, 431b12). ${ }^{80}$ Portanto, no De Anima, qualquer discurso é considerado metafórico por natureza, "pois os noeta, os conceitos, são imagens mentais que substituem os aistheta, os objetos da percepção. Os signos verbais, orais e escritos, são entendidos como imagens das imagens mentais"; 81 e quando Tasso e outros autores quinhentistas e seiscentistas discutem os “conceitos", retomam justamente os noeta aristotélicos.

Pois bem. Foram essas as questões dos Discorsi del poema eroico que nos pareceram ser de maior relevância para nosso trabalho. Passemos, agora, à análise de uma obra hispânica que se situa entre os séculos XVI e XVII: a Philosophía antigua poética (Madrid, 1596), de Alonso López Pinciano. ${ }^{82}$ Ela é constituída por treze epístolas dialogadas, cujas discussões dos três personagens (Fadrique, Hugo e Pinciano) seguem, primordialmente, Aristóteles, mas também, por vezes, Horácio. Ao final de cada epístola, há uma "Respuesta de Don Gabriel". Para a nossa exposição,

\footnotetext{
${ }^{78}$ Idem, IV, p.474.

${ }^{79}$ Idem, V, p.504.

${ }^{80}$ De Anima. Apresentação, tradução e notas de Maria Cecília Gomes dos Reis. São Paulo: Editora 34, 2006.

${ }^{81}$ Hansen, João Adolfo. "Retórica da agudeza”. In: Letras Clássicas, n.4, 2000, p.319.

82 Philosophía Antigua Poética. Obras completas, I. Edición de José Rico Verdú. Madrid: Biblioteca Castro, 1998.
} 
aproveitaremos a leitura e sistematização que Sanford Shepard fez do tratado, ${ }^{83}$ tomando, no entanto, os devidos cuidados com os termos inapropriados ou anacrônicos que o autor utilizou, com freqüência, para explicar os preceitos de Pinciano.

$\mathrm{Na}$ "Epístola segunda, o prólogo de la Philosophía Antigua", falando-se sobre a utilidade das artes (em particular, da música e da poética), Fadrique afirma que:

Tres provechos traen estas artes (como, por ejemplo, de la música Aristóteles, en sus Políticos, enseña): el uno, el alterar y quietar las passiones del alma a sus tiempos convenientes; el segundo, mejorar las costumbres; el tercero es el que agora dijimos, divertimiento y entretenimiento. ${ }^{84}$

Não podemos deixar de relacionar esses "proveitos" com os três ofícios do orador, respectivamente, o mouere, o docere e o delectare. A partir disso, o diálogo expõe e rebate as criticas de Platão à poesia. Esta, ao contrário do que defendeu aquele na sua República, é uma "arte buena, y útil, y necessaria". ${ }^{85}$ Assim, Hugo conclui, ironicamente, a respeito de Platão: "Este philósopho espaldudo fue muy facundo y dijo mal de la Rhetórica en la Gorgia; y fue poeta y dijo mal de la poética en su República. ¿Si lo hizo por celar sus artes?”. ${ }^{86}$

$\mathrm{Na}$ terceira epístola, os temas debatidos são a essência e as causas da "poética". A poesia, enquanto mimesis, "no es otra cosa que arte que enseña a imitar con la lengua", e o poema "es imitación hecha con la dicha lengua o lenguaje". ${ }^{87}$ Diferentemente do que dizia Platão, a invención del poeta é uma primeira imitação e não uma mimesis de segunda mão, como a pintura, "porque el autor que remenda a la naturaleza es como retratador y el que remenda al que remendó a la naturaleza, es simple pintor. Así que el poema que inmediatamente remeda a la naturaleza y arte, es como retrato, y el que remedó al retrato, es como simple pintor". ${ }^{88}$ Se o fim da poesia, como queria Horácio, é unir a doutrina com o deleite, o bom poeta deve tratar de

\footnotetext{
${ }^{83}$ El Pinciano y las Teorías Literarias del Siglo de Oro. Segunda edición aumentada. Madrid: Gredos, 1970.

${ }^{84}$ Philosophía Antigua Poética, epístola segunda, op.cit., p.90.

${ }^{85}$ Idem, ibidem, p.99.

${ }^{86}$ Idem, ibidem, p. 105.

${ }^{87} \mathrm{Idem}$, epístola tercera, p.110.

${ }^{88}$ Idem, ibidem, p.111.
} 
filosofia moral ou natural em sua obra. ${ }^{89} \mathrm{Na}$ verdade, o "sujeto de la poética es cuanto cabe debajo de lengua y pluma”, ou seja, tudo é matéria para o poeta. ${ }^{90}$

E a imitação poética tem que ser verossímil. Na quarta epístola, é referida a conhecida diferenciação da poesia (universal) e da história (particular) feita por Aristóteles em sua Poética. Por visar tal universalidade, o poema não precisa mimetizar a verdade das coisas, mas fingir que estas são verossímeis e próximas da razão. Portanto, o essencial para a poesia é a imitação, a verossimilhança, a universalidade, e não o metro; talvez por isso Pinciano, na terceira epístola, tenha dito sobre a obra de Heliodoro: "Y he caído en la cuenta que la Historia de Ethiopia es un poema muy loado, mas en prosa". 91

A quinta epístola discute a noção de "fábula", definida por Hugo desta maneira:

la fábula es imitación de la obra. Imitación há de ser, porque las ficciones que no tienen imitación y verisimilitud, no son fábulas, sino disparates, como algunas de las que antiguamente llamaron milesias, agora libros de cabellerías, los cuales tienen acaecimientos fuera de toda buena imitación y semejanza a verdad. Ha de ser, digo, imitación de obra y no ha de ser la obra misma; por esta causa Lucrecia, y Lucano, y otros así, que no contienen fábulas, no son poetas; digo, porque no imitan en sus escritos a la cosa, sino escriben a la cosa como ellafue, o es, o será..$^{92}$

A respeito dessa definição, Sanford Shepard faz o seguinte comentário:

\footnotetext{
89 "Y, en suma, la poética es arte inventada, como todas las demás, para bien y útil deleite del mundo; de la cual fue origen y principio el fin, que ya es dicho y otra vez digo: la dotrina con el deleite. (...) Así que el buen poeta o ha de tocar la philosophía moral, o natural, en su obra" (Idem, ibidem, pp.120-121).

${ }^{90}$ Embora utilize impropriamente o termo "literatura" para designar a "poesia" de que fala Pinciano, Sanford Shepard assim sintetiza a questão: "Para resumir el concepto básico que Pinciano tiene de la literatura, es preciso decir que, para él la literatura se interesa por todo el conocimiento y todas las actividades. Como el universo aunténtico, el cosmos creado por la literatura contiene artes, ciencias, ciudades, naciones, hombres de todas clases, etc., concebidos de acuerdo con princípios de la naturaleza. (...) De esta forma, la literatura viene a ser una especie de vademécum para la vida que, además, está libre de las vicisitudes decepcionantes del mundo físico. Produce tipos ideales, es decir, es universal. En la literatura, el proceso natural puede dar sus frutos, mientras en la vida real tiene que fracasar parcialmente, y en este sentido, la literatura puede convertirse en el medio más valioso con que corregir y guiar a la sociedad" (El Pinciano y las Teorías Literarias del Siglo de Oro, op.cit., p.55).

${ }_{91}^{91}$ Philosophía Antigua Poética, epístola tercera, op.cit., p.116.

${ }^{92}$ Idem, epistola quinta, pp.172-173.
} 
Pinciano separa la trama poética (el aristotélico $\mu v \theta o \varsigma$ ) de la narración

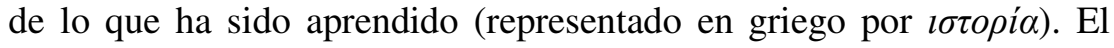
universo ficticio creado por el poeta está gobernado por los mismos principios que lo está el mundo real sin más restricción en los detalles que la impuesta por la imaginación del autor mismo. A pesar de ello, el poeta no debe introducir modificaciones, porque así como el arquitecto debe someterse a las leyes immutables de las matemáticas, el poeta debe hacerlo a los principios invariables de la naturaleza. ${ }^{93}$

Desse modo, o poeta é o "Inventor" desse cosmos fictício assim como Deus o é do mundo: "Así que la poética hace la cosa y la cria de nuevo en el mundo y por tanto le dieron el nombre griego que, en castellano, quiere decir « hacedora »; como poeta, « hacedor », nombre que a Dios solamente dieron los antiguos". ${ }^{94} \mathrm{E}$ a fábula inventada, para proporcionar deleite e doutrina, há de ter três condições: ser una e vária, perturbadora e aquietadora, admirável e verossímil.

Quanto à linguagem poética, assunto da sexta epístola, vale a pena destacar, em primeiro lugar, as considerações sobre a obscuridade da poesia, que já indicam, claramente, as discussões seiscentistas. São quatro as causas da obscuridade: a primeira é quando um poeta, "de indústria", não quer ser compreendido por todos os leitores; a segunda é provocada pela grande erudição e "lição" do poeta, não sendo sua a culpa pela obscuridade, e sim do leitor que não consegue entender o poema por não ter a mesma erudição; a terceira é uma obscuridade má e viciosa, que os bons poetas jamais usaram, pois nasce da falta de engenho na invenção ou na elocução, apresentando conceitos intricados e difíceis ou dispondo confusamente os vocábulamos de modo que não se possa compreender a oração; por fim, há a obscuridade dos livros sagrados, chamada de alegórica ou de sentido alegórico. ${ }^{95}$

Ainda em relação à linguagem, são mencionados os três estilos ou "géneros de decir": baixo, mediano ou moderado e alto. Nos poemas sem metro, não é necessária uma linguagem alta e peregrina, como o poema de Heliodoro demonstra. Para a poesia em prosa, o que convém é um "vocábulo" mais moderado, sem muitas alterações, diferentemente do que se recomenda ao poema com metro, cuja característica que o

\footnotetext{
${ }^{93}$ El Pinciano y las Teorías Literarias del Siglo de Oro, op.cit., p.57.

${ }^{94}$ Philosophía Antigua Poética, epístola quinta, op.cit., p.174.

${ }^{95}$ Idem, epístola sexta, p.253.
} 
engradece é uma linguagem alta e peregrina. Sobre o decoro do "género de decir" com o ethos do personagem , Fadrique explica:

Y aunque cierta manera contradiga a la perfecta imitación, digo, conforme a doctrina del Philósopho, que no desconviene en todo género de personas el peregrino lenguaje, y que el siervo no parece mal hable en lenguaje alto y a la pastorcilla le parece bien; mas no por esto condenó Aristóteles, ni yo condeno, a los que, siguiendo el rigor de la poética forma, guardaren la perfeta imitación, como lo hizo el sumo poeta latino, el cual fue tan primo que, guardando la puridad de la imitación, fue tan deleitosíssimo en su oración y supo usar de tal manera de las figuras bajas en lo bajo, como de las altas en lo alto. Y, si no, mirad esas Bucólicas cuán agradables son en su lenguaje humilde. ${ }^{96}$

A respeito desse trecho, é curioso notar como aquilo que o autor da Constante Florinda diz, no "Prólogo ao Leitor" da segunda parte, rebatendo as críticas que tinham sido feitas à primeira parte da obra, é muito semelhante a essa fala de Fadrique. Ambos defendem, tendo em vista a auctoritas do modelo virgiliano, a linguagem elevada nos personagens rústicos:

há entendimentos que notam dizerem pastores ou mulheres, em o discurso de suas histórias, fábulas, ou sentenças ou motes avisados, dizendo que eles são rústicos e elas pouco lidas para serem tão práticas, outros notam cousas similhantes a estas. Os quais dão nota de si em porem estas notas em as obras alheias, porque mostram não ter lido Virgílio, nem outros autores antigos, nem ainda muitos modernos que aprenderam deles, nem consideram que esse é o cabedal dos Autores. ${ }^{97}$

\footnotetext{
${ }^{96}$ Idem, ibidem, p. 266.

${ }^{97}$ Segunda Parte da Constante Florinda, p.131. Para as citações da Constante Florinda parte II, sempre utilizaremos a excelente edição de Artur Henrique Ribeiro Gonçalves em sua tese de doutorado (Infortúnios Trágicos da Constante Florinda de Gaspar Pires de Rebelo: Uma Novela de Amor e Aventuras Peregrinas, op.cit., pp.129-312). Isso porque, essa edição está baseada naquela cujos exemplares são os mais antigos que se conhecem: Segunda Parte da Constante Florinda: Em que se trata dos infortunios que teve Arnaldo buscandoa pelo mundo. Lisboa: António Álvares, 1635. Mas também cotejamos o texto apresentado por Artur Gonçalves com aquele da edição de 1761 (Constante Florinda, em a qual se dá conta dos infortúnios, que teve Arnaldo, buscando-a pelo mundo. Author o Licenciado Gaspar Pires de Rebelo, Prior de Castro Verde, e natural de Aljustrel do Campo de Ourique. E agora nesta impressão correcta, e emendada. Parte II. Lisboa: Na Officina de Francisco Borges de Sousa, 1761) e com aquele da edição recente (2005), já mencionada, de Nuno Júdice. Para o texto da segunda
} 
Para finalizar, a última questão referente à linguagem que queremos destacar na sexta epístola da Philosophía antigua poética diz respeito aos "conceitos". Eis sua definição, que é bastante semelhante àquela de Tasso e, conseqüentemente, também depende do noetos aristotélico: "concepto se dice una imagen que de la cosa el entendimiento forma dentro de sî". ${ }^{98}$ São três as espécies de conceitos: uns são graves e convêm à nobreza, outros agudos e são adequados à "gente menor" e os últimos não são nem graves nem agudos, mas medianos.

Na décima primeira epístola, são feitas considerações acerca da "Heróica". Vejamos algumas delas. O herói dessa poesia deve ser um exemplo cristão, mas os temas hão de ser, preferencialmente, seculares. Defende-se a unidade de ação, que, causando uma estreita relação entre os diversos episódios do poema, restringe sua extensão. Porém, cada episódio tem que se constituir como uma unidade em si, igual ao que se observa na Eneida e na Ilíada, para que a inclusão ou exclusão dos episódios não altere o todo da epopéia. Com relação às técnicas para se iniciar a narração, é preferível que se comece in media res, como Heliodoro o fez com perfeição; no entanto, também é adequado o início ab ovo.

Ao poeta da épica, recomenda-se "hablar lo menos que él pueda", deixando ao herói narrar seus próprios infortúnios passados. ${ }^{99}$ Mas qualquer narração há de ser feita levando-se em consideração os usos e os costumes dos lugares em que se passa a história e o sexo, idade e estado de vida dos personagens; tudo para que não se prejudique a verossimilhança da fábula.

Enfim, a Heróica é definida como "imitación común de acción grave”:

Por «común» se distingue de la trágica, cómica y dithirámbica, porque ésta es enarrativa y aquellas dos, activas; y por «grave» se distingue de algunas especies de poética menores, como la parodia y de las fábulas apologéticas, y aun estoy por decir de las milesias o libros de cabellerías, los cuales, aunque son graves en cuanto a las personas, no lo son en las demás cosas requisitas. No hablo de un Amadís de Gaula ni aun del de Grecia y otros pocos, los cuales tienen mucho de bueno;

parte da Constante Florinda, Júdice seguiu a impressão de 1721: Lisboa Ocidental, na Oficina Ferreiriana.

${ }^{98}$ Philosophía Antigua Poética, epístula sexta, op.cit., p.275.

${ }^{99}$ Idem, epístola undécima, p.483-484. 
sino de los demás que ni tienen verisimilitud, ni doctrina, ni aun estilo grave... ${ }^{100}$

Como se nota, nessa definição salvou-se, entre os livros de cavalaria, o Amadís de Gaula, modelo importante em muitos episódios da Constante Florinda. Além do Amadis, já tinham sido poupados das críticas às "fábulas milesias" outros dois modelos da epopéia em prosa seiscentista: as obras de Heliodoro e Aquiles Tácio, consideradas tão "épicas" como a Ilíada ou a Eneida: "de manera que los Amores de Theágenes y Cariclea de Heliodoro y los de Leucipe y Clitofonte de Achile Estacio son tan épica como la Ilíada y la Eneida". ${ }^{101}$

Se a ação trágica se aperfeiçoa com um fim também trágico, uma vez que o deleite do auditório decorre da compaixão incitada, o poema épico "tiene deleite sin el fin trágico". ${ }^{102}$ Como veremos, nada trágico será o final da primeira parte da Constante Florinda, bem diferente do que se observará na segunda parte, mas ambas com um caráter moralizante. Como afirma Sanford Shepard, nos séculos XVI e XVII, a poesia tinha um precípuo "propósito didático" que não se restringia ao "ensinar": era, além disso, um elemento fundamental para que o poema fosse considerado verdadeiramente belo. $^{103}$

Por fim, vale a pena citar outras palavras do mesmo Shepard: "La generación de Pinciano ignora el término 'novela' en su sentido moderno y, por lo tanto, cualquier narración larga, ficticia y en prosa pertenece, en su opinión, al género épico". ${ }^{104}$ Isso se comprova na Philosophia antigua poética pelas numerosas menções, sempre elogiosas, a Heliodoro, colocado entre os grandes autores épicos, pouco importando que se trate de uma obra em prosa.

Como já mencionamos, Il libro del cortegiano de Castiglione e o Galateo de Della Casa foram os principais modelos de um tratado publicado em Portugal no século XVII: Corte na aldeia e noites de inverno (1619), de Francisco Rodrigues Lobo. ${ }^{105}$ Desta obra, interessam-nos os diálogos IX, X e XI, nos quais são abordadas questões relevantes para se pensar num narrador seiscentista. No diálogo IX (Da prática e

\footnotetext{
${ }^{100}$ Idem, ibidem, p.467.

${ }^{101}$ Idem, ibidem, p.461.

102 Idem, ibidem, p. 455.

${ }^{103}$ El Pinciano y las Teorías Literarias del Siglo de Oro, op.cit., p.126.

${ }^{104}$ Idem, p. 127.

${ }^{105}$ Corte na Aldeia e Noites de Inverno. Prefácio e notas Afonso Lopes Vieira. $3^{\mathrm{a} e d .}$ Lisboa: Sá da Costa, 1972.
} 
disposição das palavras), são apresentadas cinco advertências para quem deseja falar bem: falar vulgarmente com propriedade; fugir da prolixidade; não confundir as razões com brevidade; não enfeitar com brevidade as palavras; e não descuidar com a confiança. ${ }^{106}$ As duas primeiras regras dizem respeito tanto à clareza como à brevidade recomendadas nas retóricas antigas. Deve-se falar vulgarmente com propriedade e fugindo da prolixidade, em suma, para que o discurso seja claro e breve e todos possam compreender o que é dito. Veremos, na análise específica da Constante Florinda, que o narrador avisa a todo momento que evitará a prolixidade sobre determinado acontecimento ou assunto, para impedir que seus leitores não compreendam o que é narrado ou fiquem entediados. Na Corte na Aldeia, Leonardo, o personagem responsável por conduzir essa discussão, afirma que falar vulgarmente "é qual os melhores falem e todos entendam: sem vocábulos estrangeiros, nem esquisitos, nem inovados, nem antigos e desusados, senão comuns e correntes, sem respeitar origens, derivações, nem etimologias; que a linguagem mais pende do uso que da razão e por isso se chama língua materna". ${ }^{107}$ Com relação à prolixidade o mesmo personagem comenta: "Há muitos homens (prosseguiu Leonardo) tão palavrosos que vos não deixam tomar carta na conversação, e são tão amigos de levarem um comprimento té o fundo que nem com o silêncio vos defendeis dos seus; e é vício de que se há-de fugir como de peste da discrição". ${ }^{108}$

A terceira e a quarta advertências são, explicitamente, voltadas para a brevidade do discurso, sendo que a "prática" não deve ser nem muito comprida, pois prejudica a memória, nem muito breve, para não se tornar obscura e cegar o entendimento. O seguinte trecho sintetiza bem os preceitos acerca da matéria:

Não sou eu o primeiro (respondeu ele) que o disse, que já o poeta se queixou que, quando queria ser breve, ficava escuro. E, verdadeiramente, a prática comprida não a compreende a memória, e a mais breve do necessário cega o entendimento; e há muitos que, por abreviarem o que dizem, não declaram o que querem, que posto que a brevidade seja louvada, e por ela se aventajassem os Lacónicos na

\footnotetext{
${ }^{106}$ Idem, IX, p. 175.

${ }^{107}$ Idem, ibidem.

${ }^{108}$ Idem, IX, p. 181.
} 
linguagem dos outros Gregos, o cortesão nem há-de dizer as cousas em três palavras, nem em trezentas. ${ }^{109}$

Quanto à última advertência, são citados três "descuidos": "O primeiro descuido da confiança, e o que fica mais em descrédito do cortesão, é quando entre mulheres principais usa de algumas palavras que, ou no som ou na matéria, ofendam a honestidade de seu estado"; ${ }^{110}$ o segundo "é quando o discreto fala ou alega latins entre pessoas que o não sabem, ou que não têm a obrigação de o entender (...); ou conta diante delas histórias da Índia, ou de outras regiões remotas onde esteve, dizendo as cousas com muitas palavras dos nomes próprios daquelas partes"; ${ }^{11}$ finalmente, o último descuido, considerado o mais perigoso, ocorre quando, ao discorrer sobre assunto que possa ofender a terceiro, a pessoa, inadvertidamente, não se aperceba, "antes de falar, se está na presença a quem toque por sangue ou amizade a ofensa que se faz ao ausente, ainda que seja em matéria leve; ou se está ali outro do mesmo estado de que se murmura, do mesmo cargo, vício ou costume". ${ }^{112}$

Passando ao diálogo X (Da maneira de contar histórias na conversação), são feitas considerações interessantes a respeito da "arte de narrar". No referido diálogo, trata-se do tema deste modo: algum personagem fica incumbido de relatar um caso; terminado o relato, os outros fazem seus comentários. Assim, depois que o Licenciado conta uma longa história, o Doutor resume as prescrições para se fazer uma boa narração:

\footnotetext{
Maravilhosa é a história para exemplo (disse o Doutor) e também poderá servir desse no como se devem contar outras semelhantes: com boa descrição das pessoas, relação dos acontecimentos, razão dos tempos e lugares e uma prática por parte de alguma das figuras que mova mais a compaixão e piedade; que isto faz dobrar depois a alegria do bom sucesso. ${ }^{113}$
}

Nesse trecho, há, pelo menos, dois preceitos que já destacamos ao analisar os tratados poéticos e retóricos antigos. Nessas obras, recomenda-se freqüentemente, para

\footnotetext{
${ }^{109}$ Idem, IX, pp.181-182.

${ }^{110}$ Idem, IX, p.183.

${ }^{111}$ Idem, IX, p. 184.

112 Idem, IX, pp.184-185.

${ }^{113}$ Idem, X, p. 199.
} 
que a narração seja clara e verossímil, que as pessoas sejam bem descritas, os fatos bem detalhados e os acontecimentos estejam devidamente situados no tempo e no espaço. Além disso, esse mesmo trecho nos faz lembrar daquilo que determinou Aristóteles na Poética: a tragédia tem que suscitar o terror e a piedade nos espectadores; já na Corte na Aldeia, numa nítida referência à lição aristotélica, propõe-se que, através de algumas "figuras", se mova mais a compaixão e a piedade do que o terror.

Logo em seguida, Leonardo afirma sobre a mesma história do Licenciado: "Somente (...) me pareceu comprida, sendo a matéria dela muito breve". Tal asserção incita um outro personagem (Feliciano) a diferenciar os contos das histórias, com colocações instigantes para se refletir sobre o decoro que há de ter o narrador ao discorrer em diferentes gêneros, cuidando para não infringir as regras específicas de cada um deles:

\footnotetext{
Essa diferença (lhe tornou Feliciano) me parece que se deve fazer dos contos às histórias; que elas pedem mais palavras que eles, e dão maior lugar ao ornamento e concerto das razões, levando-as de maneira que vão afeiçoando o desejo dos ouvintes; e os contos não querem tanto de retórica porque o principal em que consistem é a graça do que fala, e na que tem de seu a cousa que se conta. ${ }^{114}$
}

Por fim, no diálogo XI (Dos contos e ditos graciosos e agudos na conversação), há uma diferenciação dos gêneros de contos. Com relação aos graciosos, são citadas diversas espécies e dados muitos exemplos, que não convêm serem mencionados neste trabalho. O que vale a pena destacar é a definição dos ditos agudos, por ser a agudeza uma característica tão cara ao século XVII e que, portanto, tem que ser levada em consideração na análise de um narrador que se constitui num escrito seiscentista:

Os ditos agudos consistem em mudar o sentido a uma palavra para dizer outra cousa, ou em mudar alguma letra ou acento à palavra para lhe dar outro sentido, ou em um som e graça com que nas mesmas cousas muda a tenção do que as diz. ${ }^{115}$

\footnotetext{
${ }^{114}$ Idem, X, p.199.

${ }^{115}$ Idem, XI, p.222.
} 
Ainda no século XVII, um outro autor português, Manuel Pires de Almeida, escreve sobre questões relevantes para nossa discussão. Em seu Discurso sobre o Poema Heróico ${ }^{116}$, afirma, com os mesmos termos de Pinciano, que a "fábula" tem como condições "ser uma, e vária; perturbadora, e quietadora dos ânimos; admirável e verossímil". ${ }^{117}$ A ação será una desde que se focalize numa única pessoa, o Herói, como Enéias na Eneida; porém, há de ser, ao mesmo tempo, vária, "porque a fábula tanto tem de deleitosa, quanto de variedade". ${ }^{118}$ Quanto ao segundo par de condições ("perturbadora" e "quietadora"), o autor seiscentista, baseando-se em Aristóteles, referese apenas à perturbação, que "é uma ação cheia de alegria, ou tristeza" e que pode ser obtida por duas maneiras: "por espanto, ou por comiseração". ${ }^{119}$ Por fim, é necessário mesclar a admiração à verossimilhança; faltando a primeira, não haverá delectare nem mouere; ausente a segunda, não existirá imitação e, conseqüentemente, nem mesmo poesia. Por isso, "o poeta de tal maneira há de ser admirável que não exceda os termos da semelhança, da verdade". ${ }^{120}$

$\mathrm{Na}$ análise da narração da Constante Florinda, em especial, não só esses preceitos serão úteis, mas também o que recomenda Pires de Almeida sobre o "fim do Poema”, principalmente no que se refere à imitação das virtudes dos heróis perfeitos:

O fim da épica há de ser sempre deleitoso, e alegre por razão do sujeito principal dela, para o qual ordinariamente se busca um Príncipe de muito valor, e amador da justiça, e de sumas perfeições, a quem convém fim felice, e bem-aventurado, para que a fábula seja bemacostumada, e não persuada a desperação, antes convide à imitação das virtudes, que propõe perfeitíssimas no Herói, de que se canta. ${ }^{121}$

Se já vimos que na techne retórica a narração é definida como aquela parte da dispositio em que se expõem os fatos, devendo ser feita, preferencialmente, depois do exórdio e antes de serem apresentados os argumentos do discurso, observemos, então, como é ela situada na dispositio poética, em particular, na "disposição" que se propõe

\footnotetext{
${ }^{116}$ Manuscrito redigido por volta de 1633 e atualmente depositado no Arquivo Nacional da Torre do Tombo, em Lisboa. Foi publicado, recentemente, por Adma Muhana: REEL - Revista Eletrônica de Estudos Literários, Vitória, n.2, 2006. Disponível em: http://www.ufes.br/ mlb/reel2/AdmaMuhana.pdf

117 Idem, fl.631 v.

118 Idem ibidem.

119 Idem ibidem.

${ }^{120}$ Idem ibidem.

121 Idem, fl.633.
} 
no Discurso sobre o Poema Heróico. Conforme o autor, a "Épica" se divide em cinco partes: prólogo, proposição, invocação, "dedicação" e narração, sendo que esta última "é todo o resto do Poema, e assim há se de guardar nela o que está referido da fábula, e mais parte". ${ }^{122}$ Essa é a definição poética do termo, que se constitui como a parte mais extensa da epopéia e na qual é contada toda a "fábula" do poema.

Para que tal narração seja adequada, é preciso levar em consideração a linguagem a ser utilizada. Pensando-se nos três gêneros de estilo (o grandíloco, o medíocre e o ínfimo), "a Heróica, como imitação dos melhores, e dos Heróis, usa do grandíloco". ${ }^{123}$ E a "grandeza" do estilo ou se faz por meio dos tropos e figuras, ou das palavras, ou dos conceitos. Para o conhecimento e emprego adequado dos tropos e figuras, Pires de Almeida deixa explícito que o poeta deve recorrer à retórica: "e advirto, que tenho por impossível ser poeta sem o conhecimento da Retórica". ${ }^{124}$ Quanto às palavras, recomenda o ornato, porém praticado de modo comedido e grave, sem a "pintura lírica": "As palavras próprias para a Heróica em suma são todas aquelas, que estão em uso, e se podem falar diante de pessoas graves, aos quais o ornato de figuras é conveniente, mas não muito pintado, e florido, porém com gravidade Heróica, e não com pintura lírica, donde estas cores se desejam". ${ }^{125}$ Finalmente, o autor apresenta três espécies de conceitos: os graves, os agudos e os circunflexos (que mesclam coisas graves e agudas). É importante ressaltar o que é dito sobre as duas primeiras espécies, tão discutidas nas "letras seiscentistas":

Conceito grave se diz a notícia que o homem concebe da coisa, que é magnífica, e alta, ou aquele, que o entendimento forma da coisa maior que ela é; com este gênero de conceito foi feita a Ilíada, e Eneida, e esta se deve freqüentar na Épica. O conceito agudo, é o que forma o entendimento muitas vezes menos da coisa que é, porém mais sutil e delicado, e este não serve para a epopéia: assim porque como o Poema Heróico deve de ser feito em linguagem peregrino, e com conceitos agudos se faria enigmas, e nada inteligível. ${ }^{126}$

\footnotetext{
${ }^{122}$ Idem, fl.633v.

${ }^{123}$ Idem ibidem.

${ }^{124}$ Idem, fl.634.

${ }^{125}$ Idem, fls.634-634v.

${ }^{126}$ Idem, fl.634v.
} 
Portanto, a linguagem adequada à poesia épica deve ser aquela em que o "estilo" se faz "grande" por meio de conceitos graves, próprios aos assuntos "heróicos", e não através de conceitos agudos, que muitas vezes podem se tornar enigmas ininteligíveis. No que diz respeito a esse tema, é preciso destacar que Pires de Almeida está discutindo questões muito específicas da poesia do século XVII: "o poetar do nosso tempo". ${ }^{127}$ Por isso, em seguida, critica os poetas, "cultos" por ironia, "que afetam tanto a obscuridade, que querem qualificá-la por verdadeira poesia (...), que não achei até agora autor sábio em esta arte, que aprovasse doutrina tão falsa, e mal-fundada". ${ }^{128}$ No entanto, termina defendendo o emprego de três tipos de obscuridade (uma boa, outra louvada e a terceira alegórica e prezada) e recriminando apenas um tipo: a obscuridade viciosa, "que se produz da falta de invenção, de confusão de engenho, de ruim colocação de conceitos intricados, e dificultosos, da disposição das palavras, dos tropos, das figuras, da eleição das coisas, et sic de coeteris". ${ }^{129}$

Um outro texto do mesmo Manuel Pires de Almeida, Poesia e Pintura, ou, Pintura e Poesia, ${ }^{130}$ apresenta considerações pertinentes ao nosso trabalho. O tratado, como o próprio título indica, discute o repisado tópico da relação entre a poesia e a pintura: "quando se escreve se pinta, e quando se pinta, se escreve". 131

O aspecto "ético" e a capacidade persuasiva da narração, já afirmados em autores antigos como Aristóteles e Quintiliano, são reafirmados na obra de Pires de Almeida, num trecho em que menciona Platão, visando a ressaltar o perigo que representa a poesia lasciva e desonesta para a República:

É particularidade da imitação poética, como tem Platão, infundir dissimuladamente no ânimo o mal ou o bem que narra, e assim sendo sua narração desonesta, subrepticiamente introduzirá a mesma; e assim é aviso fugir por não manchar a pureza do ânimo com os mimos e regalos lascivos da poesia pouco casta; e fazendo-o pelo contrário pecaremos de malícia, e viveremos como Ulisses com Calipso, ou

\footnotetext{
${ }^{127}$ Idem, fl.635.

${ }^{128}$ Idem ibidem.

${ }^{129}$ Idem, fl.635v.

${ }^{130}$ Poesia e pintura, ou, Pintura e poesia: tratado seiscentista de Manuel Pires de Almeida. Adma Muhana; tradução do latim de João Ângelo Oliva Neto. São Paulo: Fapesp; Edusp, 2002.

${ }^{131}$ Idem, p.69. Outros trechos do texto também expõem tal relação: "Pintura, poesia muda; poesia, pintura que fala" (p.70); “À poesia chamaram também muitos, que vem quase a ser o dito, pintura das orelhas, e à pintura poesia dos olhos" (p.71); etc.
} 
como Reinaldo com Armido; e a poesia será totalmente nociva à República e não dará satisfação ao fim que se propõe. ${ }^{132}$

Para o autor, além do ethos, o pathos também tem um papel fundamental na poesia, e, seguindo Horácio, afirma que o poeta e o pintor devem, primeiro, mover em si os afetos, para depois arrebatarem os ouvintes e ventes:

Para fazer eleição da idéia mais excelente e da forma mais notável, convém ao poeta e ao pintor mover primeiro em si os afetos, porque assim moverão os ânimos, e desta moção procede o furor que enleva e arrebata, não só ao pintor e poeta, mas aos ouvintes e ventes. ${ }^{133}$

A poesia e a pintura, para afetarem e moverem, hão de ser verossímeis, cabendo ao poeta ou pintor "imitar, inventar e representar as coisas que são, que podem ser, ou que os antigos tiveram por verdadeiras, fugindo-se sempre de invenções fantásticas e malênconicas, que carecem de correspondência e semelham aos sonhos dos frenéticos". 134

Quanto às digressões (inúmeras na Constante Florinda), Pires de Almeida explica que são "desvios" em relação ao primeiro intento, mas que nascem e dependem dele. Na "fábula" do poeta e na "história" do pintor, ${ }^{135}$ a digressão se chama, respectivamente, episódio e parergo. No entanto, a unidade jamais deve ser prejudicada: "Unidade na pintura e unidade no poema em ação e em pessoa: história e fábula têm por fim unum unius". 136

$\mathrm{Na}$ "locução" da poesia, ${ }^{137}$ o que nos parece fundamental naquilo que o autor expõe é a necessidade de um "decoro" entre as palavras e as coisas; estas têm que ser revestidas apropriadamente por aquelas, como se cada assunto tratado fosse uma pessoa de determinada condição e numa situação específica, a ser devidamente trajada. "Há-se de procurar em suma sempre locução conveniente à matéria, de tal sorte que se pareça ver com os olhos a mesma coisa". 138

\footnotetext{
132 Idem, p.88.

${ }^{133}$ Idem, p.89.

${ }^{134}$ Idem, p.98.

135 "A obra do pintor é a história (...). A obra do poeta é a fábula" (Idem, p.95).

${ }^{136}$ Idem, p. 101.

137 "O mesmo é cor na pintura que locução na poesia, e assim como na pintura não basta rascunho sem cor, assim na poesia não basta fábula sem locução” (Idem, p.103).

${ }^{138}$ Idem, p. 110.
} 
Para encerrar as observações a respeito do tratado Poesia e Pintura, ou, Pintura e Poesia, há um longo trecho (cujo modelo, como mencionamos, é Tasso) em que a epopéia é comparada a um "retrato do universo", por ter a poesia épica tanta variedade como a que há no próprio mundo, sendo que o poeta, na sua "criação", imita o "supremo criador e artífice do universo". Enfim, do mesmo modo que o mundo é "um" e vário, a epopéia, "com ficar uma, põe diante dos olhos cidades, exércitos, batalhas, armadas, navegações, tempestades, cercos, encontros, tomadas, e para que o diga em uma só palavra, várias e quase infinitas formas e venturas". ${ }^{39}$

Ainda entre os escritos de autores seiscentistas, é possível refletir, a partir da obra de Baltasar Gracián, Agudeza y Arte de Ingenio, ${ }^{140}$ sobre outros aspectos que permitem uma compreensão mais adequada da "narração" e do "narrador" de um texto fictício do século XVII, direcionando sempre o nosso foco para o narrador da Constante Florinda. Este tem como uma de suas principais características o fato de ser extremamente sentencioso, e Gracián, no discurso XXIX (De la agudeza sentenciosa), acentua a importância das sentenças para a narração, sem as quais a história se torna insossa aos gostos mais judiciosos:

Las sentencias y las crisis sazonan la historia, que sin estos dos resabios es insulsa la narración, especialmente a gustos juiciosos, a profundas capacidades. Y aunque cualquiera sentencia es concepto, porque esencialmente es acto del discurso una verdad sublime, recóndita y prudente... $^{141}$

Os "conceitos sentenciosos" não servem somente para concluir de forma arrebatadora um texto, mas também podem ser espargidos durante toda a narração: "No sólo sirven para concluir perfectamente un epigrama o un soneto estos conceptos sentenciosos, sino que en medio de una naración o discurso se dejan caer como perlas de la aurora, sobre las fragantes flores". ${ }^{142}$

Além das sentenças, o autor, no discurso XXX, refere-se aos "ditos heróicos", que são mais próprios para exprimir as virtudes de um "grande peito": "Así como hay sentencias que exprimem la profundid de la mente, lo substancial de la inteligencia, así

\footnotetext{
${ }^{139}$ Cf. Idem, pp.141-143.

${ }^{140}$ Agudeza y Arte de Ingenio. Edición, introdución y notas de Evaristo Correa Calderón. Madrid: Castalia, 1987. 2t.

${ }^{141}$ Idem, t.2, p.22.

${ }^{142}$ Idem, t.2, p.29.
} 
hay dichos magnánimos que declaran con excelencia la grandeza del valor, la valentia del corazón y la generosa majestad de un grande pecho". ${ }^{143}$

Como última questão significativa para nossa discussão, Gracián, no discurso LXII (Ideas de hablar bien), faz uma detalhada diferenciação de dois gêneros de estilo: o natural e o artificial. Essa distinção se refere a um tema que tem grande repercussão no século XVII, implicando numa prescrição severa de um uso da linguagem sempre adequado e conveniente, como verificamos quando Manuel Pires de Almeida, no Discurso sobre o Poema Heróico, afirma não ser apropriado empregar conceitos agudos na epopéia. Para o autor espanhol, os estilos natural e artificioso têm diferenças bastante evidentes, sendo as características de cada um deles enaltecidas por seus defensores:

Otros dos géneros de estilo hay célebres, muy altercados de los valientes gustos, y son el natural, y el artificial; aquél, liso, corriente, sin afectación, pero proprio, casto y terso; éste, pulido, limado, con estudio y atención; aquél claro, éste dificultoso. Aquél, dicen sus valedores, es el propio, grave, decente; en él hablamos de veras, con él hablamos a los príncipes y personajes autorizados; él es eficaz para persuadir, y así muy propio de oradores, y más cristianos: es gustoso, porque no es violento; es substancial, verdadero, y así el más apto para el fin del habla, que es darnos a entender. El artificioso, dicen sus secuaces, es más perfecto, que sin el arte siempre fue la naturaleza inculta y basta; es sublime, y así más digno de los grandes ingenios; más agradable, porque junta lo dulce con lo útil, como lo han practicado todos los varones ingeniosos y elocuentes. ${ }^{144}$

Para concluir nossa exposição dos tratados, vejamos o que pode ser salientado na Nova Arte de Conceitos, de Francisco Leitão Ferreira. ${ }^{145}$ Apesar de ser uma obra publicada no século XVIII, ela busca sistematizar os princípios do "conceito" seiscentista, ${ }^{146}$ baseada em textos de autores como Gracián e Tesauro. ${ }^{147}$ No tratado de

\footnotetext{
${ }^{143}$ Idem, t.2, p.31.

${ }^{144}$ Idem, t.2, p.243.

${ }^{145}$ Nova Arte de Conceitos. Lisboa occidental: Antonio Pedrozo Galram, 1718 e 1721. 2v.

146 V. Aníbal Pinto de Castro, Retórica e teorização literária em Portugal: do humanismo ao neoclassicismo. Coimbra: Atlântida, 1973, pp.143-227.

147 Aliás, é preciso resssaltar que o fato de não termos examinado o Cannocchiale Aristotelico de Emanuele Tesauro não significa que ignoramos a importância desse tratado para a preceptiva retóricopoética do século XVII. Não fizemos tal análise apenas porque as questões discutidas na obra de Tesauro, se expostas no nosso texto, desviariam o foco e ultrapassariam os limites do estudo. No entanto, é
} 
Leitão Ferreira, a "Lição XVI", na qual o autor discorre sobre o "estilo e locução patética", parece ser a mais útil para se refletir acerca do narrador de uma obra de ficção, que almeja justamente mover os afetos de seus leitores. A relevância do pathos para o discurso, produzindo um estilo engenhoso, fica evidente na Nova Arte de Conceitos:

Os afetos pois veementes, crescidos, e obstinados, são os que engrandecem, e diminuem os objetos; eles os desfiguram, e animam; eles os contrafazem, e corrompem; eles os dividem, e confundem, mutilam, atam, unem; e finalmente eles arrebatando a alma por vários movimentos, são como as bravas ondas, que agitadas dos ventos, quebram sobre as praias, aonde apenas rolam nas areias, que logo retrocedendo, se retiram, e tornando-se para os mares no mesmo súbito instante, sobem em montes ao Céu, e descem em vales ao abismo.

Nesta revolução tempestuosa, os mesmos afetos compõem a sua locução das idéias, que a fantasia lhes ministra; e como a vexação se comunica com o engenho, engenhoso é também o seu estilo. ${ }^{148}$

O estilo ou locução patética é uma "forma, ou modo de falar apartado, e diverso do natural, e ordinário", ${ }^{49}$ pois os homens falam e exprimem conceitos de maneiras diversas: quando seus ânimos estão em sossego e quietação falam de um jeito diferente dos momentos em que são perturbados e movidos por algum afeto. Os discursos devem sempre se adequar a esses dois estados: no primeiro, as palavras têm que ser naturais, singelas e sem afetação; no segundo, elas são sempre figuradas e distantes da fala comum; no primeiro, o sossego é o que discorre; no segundo, a turbação é a que fala; no primeiro, o entendimento pinta as coisas com as tintas que a natureza e as sensações lhe dão; no segundo, o ânimo retrata os objetos com as cores que a paixão e o apetite têm. Destarte, sendo o "caráter" das figuras e dos tropos tomado dos afetos, o "estilo afetuoso" ou a "locução apaixonada" move e persuade mais do que qualquer outro, porque usa a linguagem mais apropriada para atingir os ânimos:

evidente que ao pensarmos em agudeza, conceito, engenho, metáfora etc., o Cannocchiale é uma fonte seiscentista imprescindível e uma referência obrigatória, mesmo que não explícita, para o nosso trabalho. ${ }^{148}$ Idem, Lição XVI, p.72.

${ }^{149}$ Idem, Lição XVI, p.75. 
E se me não engano, cuido que à luz desta observação, os primeiros Retóricos, que deram à eloqüência tropos, e figuras, com tantos nomes, e ofícios, tomaram todo o seu caráter, dos afetos, e comoções do ânimo; e por isso o estilo afetuoso, ou locução apaixonada, é a que move, e persuade mais, que qualquer outro; porque então é que se fala aos ânimos no idioma, que entendem. ${ }^{150}$

Segundo o autor, o estilo ou locução patética tem dois principais efeitos: o primeiro é concitar e imprimir nos ânimos os mesmos afetos e turbações que se exprimem no discurso figurado; o segundo é tornar verdadeiro ou verossímil o conceito falso, sem que se oponha à propriedade das paixões. Para que esses efeitos se introduzam nos ânimos dos ouvintes ou leitores, o orador ou o poeta deve

excogitar palavras, e figuras, que trópica, e vivamente imitem aquela espécie de paixão, que intenta mover, ou representar; e para este fim usará das mais próprias, e que animem melhor a sua imitação, fugindo sempre de termos afetados, que neste caso, são aqueles que costuma o engenho descobrir, quando o ânimo goza do sossego; porque semelhante afetação, desfigurando o caráter das paixões, torna inverossímeis os conceitos. ${ }^{151}$

Portanto, para Leitão Ferreira, uma locução que queira ser patética e verossímil há de reconhecer os diferentes graus das paixões do ânimo - umas são "intensas", algumas "remissas", outras "moderadas" - e observar o "decoro" das imagens e dos afetos descritos e imitados, ${ }^{152}$ sempre com o intuito de mover os leitores ou ouvintes.

Enfim, o que sobressai na análise dessas diversas obras é algo que já insinuamos logo no título do capítulo: até meados do século XVIII, a narração são preceitos retóricos e poéticos de como se deve narrar. Ao expor alguns desses preceitos, buscamos mostrar como a narração é uma ars narrandi, ou seja, é uma técnica de narrar. Como arte, ela pressupõe um actor, ou melhor, uma persona que narra. Porém,

\footnotetext{
${ }^{150}$ Idem, Lição XVI, pp.76-77.

${ }^{151}$ Idem, Lição XVI, p.79.

${ }^{152}$ Idem, Lição XVI, p.86.
} 
esse personagem jamais pode ser ignarus, pois tem que conhecer a ars narrandi e as coisas narradas, para colocá-las diante dos olhos como se fossem res factae. Por isso, é narrator gnarus, já que relata com as palavras as coisas que conhece. Para relatar adequadamente, o narrador deve ser claro, breve e verossímil; deve ser "ético", exprimindo caracteres, e "patético", suscitando afetos; e deve narrar, em suma, para atingir um objetivo triplo: mover, deleitar e ensinar.

Entretanto, aquele que narra só se constitui a partir do gênero da história narrada. Assim, no nosso caso, não podemos esquecer que a Constante Florinda inserese num gênero, a chamada "epopéia em prosa", que não tem sequer uma única preceptiva seiscentista a seu respeito, a não ser num manuscrito incompleto intitulado Argumento de Heliodoro (1633), do já citado Manuel Pires de Almeida. Tal gênero remonta a textos gregos e bizantinos, tais como As etiópicas, de Heliodoro, e Leucipe e Clitofonte, de Aquiles Tácio (só para citar dois importantes modelos para os autores seiscentistas), e afirma-se no século XVII ibérico (agregando a esses modelos antigos elementos das novelas de cavalaria), com obras como El peregrino en su patria, de Lope de Vega, Los trabajos de Persiles y Sigismunda, de Cervantes, e o próprio texto de Gaspar Pires de Rebelo, que é o foco das reflexões deste trabalho. Enfim, a epopéia em prosa seiscentista é uma "imitação comum de ação grave, una e extensa, narrada sem metro e com pensamento ornado, tendo por ofício mover os ouvintes pelo deleite e pelo ensinamento". ${ }^{153}$ Desse modo, é preciso pensar na narração dentro desse gênero específico:

\footnotetext{
Narratio iucunda, suauis, ornata a da epopéia em prosa, acomoda proporcionalmente os ofícios poéticos, efetuando-os ou por meio de hipérboles, reticências e prosopopéias; ou por meio de demonstrações, descrições e etopéias; ou por quaisquer outros procedimentos amplificantes com que se pense. ${ }^{154}$
}

\footnotetext{
${ }^{153}$ Muhana, Adma. A epopéia em prosa seiscentista, op.cit., p.26. Preferimos considerar a Constante Florinda como uma "epopéia em prosa seiscentista" a denominá-la uma "novela de amor e aventuras peregrinas grego-bizantinas modernas", como faz Artur Henrique Ribeiro Gonçalves em sua tese de doutorado (Infortúnios Trágicos da Constante Florinda de Gaspar Pires de Rebelo: Uma novela de Amor e Aventuras Peregrinas, op.cit., pp.cdlv-cdlxviii), porque esta última denominação reflete uma certa incompreensão na abordagem do gênero, bem como acerca da sistemática dos gêneros no século XVII.

${ }^{154}$ A epopéia em prosa seiscentista, op.cit., p.250.
} 
A persona responsável por conduzir essa narratio iucunda, suauis e ornata é justamente o narrador, que, por meio de uma elocução ético-patética, tem a difícil incumbência de relatar coisas variadas, sem ferir a unidade da história:

\begin{abstract}
Las peregrinaciones largas siempre traen consigo diversos acontecimientos y, como la diversidad se compone de cosas diferentes, es forzoso que los casos lo sean. Bien nos lo muestra esta historia, cuyos acontecimientos nos cortan su hilo, poniéndonos en duda donde será bien anudarle; porque no todas las cosas que suceden son buenas para contadas y podrían pasar sin serlo y sin quedar menoscabada la historia. Acciones hay que, por grandes, deben de callarse y otras que, por bajas, no deben decirse, puesto que es excelencia de la historia que cualquiera cosa que en ella se escriba puede pasar, al sabor de la verdad que trae consigo; lo que no tiene la fábula, a quien conviene guisar sus acciones con tanta puntualidad y gusto, y con tanta verisimilitud, que, a despecho y pesar de la mentira, que hace disonancia en el entendimiento, forme una verdadera armonía. ${ }^{155}$
\end{abstract}

Na epopéia em prosa seiscentista, o narrador se define no seu próprio discurso. E seu discurso é techne rhetorike e techne poietike. Portanto, se a epopéia é "retrato do universo", como afirmaram Tasso e Manuel Pires de Almeida, esse narrador se define imitando, tecnicamente, a mesma variedade-unidade que há, naturalmente, no mundo. Como se fosse um pintor, tem que usar convenientemente as cores seiscentistas para compor uma obra que seja, ao mesmo tempo, útil e bela; como se fosse um orador, deve dirigir-se apropriadamente aos seus ouvintes, para que estes, movidos através do deleite e do ensinamento, ajam conforme à verdade sugerida pelo discurso, como se ouvissem um conselho irrecusável dado por um velho e cuidadoso amigo. No entanto, ele não é pintor, orador, historiador ou poeta; é, isto sim, uma persona que narra o próprio texto que a constitui: uma história épica e escrita (e não pintada ou falada).

Passemos, então, aos escritos que narram as epopéias da constante Florinda e de seu amado Arnaldo.

\footnotetext{
${ }^{155}$ Cervantes, Miguel de. Los trabajos de Persiles y Sigismunda. Edición de Carlos Romero Muñoz. Madrid: Cátedra, 2004, pp. 526-527.
} 


\title{
Capítulo 2
}

\section{O narrador da Constante Florinda: uma persona que narra}

Desde os poemas homéricos, nota-se a presença evidente de um narrador (que evitaremos considerar como o "poeta") definindo, explicitamente, seu lugar na obra e deixando, a todo momento, suas marcas no texto. ${ }^{156} \mathrm{Na}$ invocação da Musa, logo no primeiro verso da Ilíada, a persona que narra a epopéia já se mostra e pede à deusa que relate a história: "Canta-me a cólera - ó deusa! - funesta de Aquiles Pelida...". ${ }^{157}$ É o que também ocorre no começo da Odisséia: "Musa, reconta-me os feitos do herói astucioso...". ${ }^{158}$ Pode-se observar tal presença, ainda mais manifesta, no trecho (outra invocação) que precede o catálogo das naus na Ilíada:

\author{
Musas, que o Olimpo habitais, vinde agora, sem falhas, contar-me \\ pois sois divinas e tudo sabeis; sois a tudo presentes; \\ nós, nada vimos; somente da fama tivemos notícia - \\ os nomes, sim, revelai-me, dos chefes supremos dos Dânaos. \\ Da multidão não direi coisa alguma, nem mesmo os seus nomes, \\ nem que tivesse dez bocas e dez, também, línguas tivesse, \\ voz incansável e forte, e de bronze infrangível o peito, \\ se vós, ó Musas, nascidas de Zeus portador da grande égide, \\ não me quisésseis nomear os que os campos de Tróia pisaram. \\ Dos chefes, pois, dos navios, direi, do conjunto das naves. ${ }^{159}$
}

\footnotetext{
${ }^{156}$ Cf. Brandão, J. L. A invenção do romance: narrativa e mimese no romance grego. Brasília: UnB, 2005, pp.93-96. Lembremos também que Auerbach fez uma análise, bastante conhecida, do "estilo" homérico em contraposição ao "estilo" bíblico, definindo como principais características diferenciadoras desses dois "estilos", respectivamente: "por um lado, descrição modeladora, iluminação uniforme, ligação sem interstícios, locução livre, predominância do primeiro plano, univocidade, limitação quanto ao desenvolvimento histórico e quanto ao humanamente problemático; por outro lado, realce de certas partes e escurecimento de outras, falta de conexão, efeito sugestivo do tácito, multiplicidade de planos, multivocidade e necessidade de interpretação, pretensão à universalidade histórica, desenvolvimento da apresentação do devir histórico e apronfundamento do problemático" ("A cicatriz de Ulisses". In: Mimesis: a representação da realidade na literatura ocidental, p.20). Nessa perspectiva, o "narrador" homérico adquire um papel fundamental na narração, chegando mesmo a desviar a atenção do enredo e a sufocar a caracterização dos personagens para dar vazão às detalhadas descrições digressivas, que interrompem, freqüentemente, o relato.

${ }^{157}$ A tradução da Ilíada utilizada é a de Carlos Alberto Nunes (Rio de Janeiro: Ediouro, 2001).

${ }^{158}$ A tradução da Odisséia utilizada também é a de Carlos Alberto Nunes (Rio de Janeiro: Ediouro, 2001).

159 Ilíada, II, vv.484-493.
} 
Como assevera Jacyntho Lins Brandão, "seria portanto inexato afirmar que o narrador homérico esconde-se detrás de uma impessoalidade que deixa todo espaço à Musa, eliminando-se como um dos elementos de enquadramento da narrativa". ${ }^{160} \mathrm{Da}$ mesma forma, nada "impessoal" é a poesia de Hesíodo; quando diz, por exemplo, que as Musas "um dia a Hesíodo ensinaram belo canto", ${ }^{161}$ personaliza, assim, a narração. Entretanto, para não cairmos no anacronismo da "subjetividade", é preciso ressaltar, como o faz Adma Muhana, que "quando um poeta da Antigüidade, ou do Seiscentos diz 'eu', diz 'eu poeta', semelhante e diferente do verdadeiro, verossímil e nada mais. Nunca, em nenhuma das artes da linguagem antigas, a verdade esteve vinculada à primeira pessoa". ${ }^{162}$

Não só nas obras poéticas gregas a figura do narrador se faz presente; nos textos dos historiadores, como Heródoto e Tucídides, "ainda que a terceira pessoa, como marca de uma buscada objetividade, seja preferencialmente adotada (...), tanto o enquadramento inicial quanto as interferências em primeira pessoa não deixam o leitor perder de vista o papel fundamental desempenhando pelo narrador". 163

Prosseguindo entre os autores antigos e direcionando o foco para o nosso trabalho, vejamos como se configuram os narradores de duas epopéias em prosa gregas: ${ }^{164}$ Leucipe e Clitofonte, de Aquiles Tácio, ${ }^{165}$ e As etiópicas, de

\footnotetext{
${ }^{160}$ A invenção do romance, op.cit., pp.97-98.

161 Teogonia, v.22. A tradução utilizada é a de Jaa Torrano (São Paulo: Iluminuras, 2006).

162 Muhana, A.F. “O gênero epistolar: diálogo per absentiam”. In: Discurso. São Paulo, USP, n.31, 2000, p.339.

163 Brandão, J. L. A invenção do romance, op.cit., p.105.

164 Acreditamos que, para definir tal gênero, o termo "epopéia em prosa”, sustentado por Adma Muhana, A epopéia em prosa seiscentista, op.cit., pp.15-33, é mais apropriado do que "romance grego", defendido por Jacyntho Lins Brandão, op.cit., pp.21-34, e vários outros autores. Como não é intenção do nosso estudo discutir questões de gênero, não exporemos, com detalhes, os motivos que nos levaram a adotar uma designação em detrimento das outras (vale lembrar que alguns autores falam também em "novela grega"). Apenas destacaremos que o termo romance (roman, romanzo), até meados do Seiscentos, aplicava-se exclusivamente aos "romances de cavalaria" e aos poemas que eram assim chamados por serem ambos escritos em língua vulgar. E utilizar tal expressão para designar textos como As etiópicas e Leucipe e Clitofonte, ou, especificamente, a Constante Florinda é, como explica Adma Muhana, "identificar a posteriori nas exigências do romance contemporâneo a dos seus supostos antecessores, e desconhecer a filologia, que atribui ao termo 'romance', no século XVII, outros modelos de discurso - e, mais do que 'desamparada', sem a filologia qualquer teorização poética se torna absurda” (p.18). Além disso, é importante salientar que "novela" também é uma denominação inadequada, pois a "epopéia em prosa" não é somente mais extensa, mas apresenta princípios e finalidades muito diferentes das chamadas "novelas", como as do Decameron de Boccaccio. Para uma discussão mais detalhada sobre a impropriedade desses dois termos em particular, veja-se Adma Muhana, op.cit., pp.18-21.

${ }^{165}$ Tácio, Aquiles. Le Roman de Leucippé et Clitophon. Trad. Jean-Philippe Garnaud. Deuxième tirage. Paris: Les Belles Lettres, 1995.
} 
Heliodoro ${ }^{166}$,- os dois principais modelos do gênero em que se insere a Constante Florinda. ${ }^{167}$

Em Leucipe e Clitofonte, a participação do narrador é bastante reduzida. Ele introduz a história falando da cidade de Sídon e afirma, em primeira pessoa, que chegou a esse lugar, depois de uma tempestade, e se deparou com uma pintura:

Sídon é uma cidade à beira-mar. O mar é o dos assírios. A cidade é Metrópole da Fenícia. O povo é pai do de Tebas. Um duplo e largo porto há no golfo, tranqüilamente bloqueando o mar (...). Chegando a esse lugar, após forte tempestade, ofereci sacrifícios à deusa dos fenícios; chamam-na Astarté os habitantes de Sídon. Passeando então pelo resto da cidade e olhando as oferendas, vejo uma pintura (graphé) votiva da terra e, ao mesmo tempo, do mar. A pintura de Europa, o mar dos fenícios, a terra de Sídon (Leucipe e Clitofonte, I, I, 1-2). ${ }^{168}$

Tal pintura é descrita longa e detalhadamente e representa o rapto de Europa por Zeus. Essa descrição dá lugar a que o narrador faça considerações sobre o poder do amor: "Eu todas as outras coisas admirava na pintura, mas, sendo amoroso, com mais atenção olhava Eros que conduzia o touro. E dizia: Como uma criança domina o céu, a terra e o mar!" (Idem, I, II, 1). A partir desse tema amoroso surge o personagem principal, Clitofonte, que assumirá a narração até o fim da obra:

\footnotetext{
É hora para ti - dizia eu - de começar o relato. Este lugar é em tudo agradável e digno de mitos de amor. E ele começa a falar assim: Eu sou de raça fenícia, minha pátria é Tiro, meu nome Clitofonte, meu pai Hípias, o irmão de meu pai é Sóstrato - não de todo irmão de meu pai, mas enquanto ambos têm o mesmo pai... (Idem, I, II, 3 - III, 1).
}

\footnotetext{
${ }^{166}$ Heliodoro. Les Éthiopiques. Trad. J. Maillor. Troisième tirage. Paris: Les Belles Lettres, 1994. 3t.

${ }^{167}$ Marcelino Menéndez y Pelayo, ao tratar do gênero que ele denomina como "novela sentimental", também se refere à importância das obras de Heliodoro e Aquiles Tácio como modelos para os autores quinhentistas e seiscentistas da península ibérica (Orígenes de la Novela. Tomo I. Madrid: Bailly, 1925, pp.CCCXIX e ss.).

${ }^{168}$ Para as citações, em português, dos textos de Aquiles Tácio e Heliodoro, valemo-nos da tradução de alguns trechos feita por Jacyntho Lins Brandão, em A invenção do romance. Porém, nossa fonte principal para a leitura dessas duas epopéias em prosa gregas foram as edições francesas, bilíngües, já mencionadas.
} 
Portanto, o narrador de Leucipe e Clitofonte, que se apresenta em primeira pessoa, tem o papel de apenas introduzir a história que, na verdade, será toda narrada, também em primeira pessoa, pelo personagem principal, não voltando jamais a se pronunciar aquele primeiro narrador. Percebe-se na configuração dessa narrativa uma situação peculiar. Nas epopéias em prosa, em geral, há um narrador onisciente que conduz toda a história, sendo que esta é recheada de relatos de vários personagens. Já no texto de Aquiles Tácio, um personagem (o protagonista) é que assume a responsabilidade de conduzir o enredo, gerando no leitor uma maior expectativa em relação aos acontecimentos, pois comunga com esse "narrador que ao mesmo tempo vive as vicissitudes da týkhe (...) as limitações da falta de onisciência". ${ }^{169}$

De outro lado, nas Etiópicas, há um típico narrador onisciente (muito mais semelhante àquele da Constante Florinda), que coordena toda a história e que sabe “jogar" com a expectativa e a curiosidade dos leitores, iniciando a narração in medias res, com uma cena grandiosa e misteriosa:

Quando o dia começava a sorrir e o sol iluminava os cumes, homens armados como piratas, em emboscada nos montes que se estendem pela embocadura do Nilo chamada de Boca de Héracles, parando um pouco, percorriam com os olhos o mar estendido abaixo e, lançando primeiramente a vista para as ondas, como nenhuma presa de pirataria elas anunciassem, sobre a planície próxima baixaram o olhar. Eis o que nela havia: um barco estava ancorado pela popa, vazio de tripulação, cheio de carga (...). A planície, toda repleta de corpos recentemente massacrados, alguns de todo mortos, outros semimortos, com os membros dos corpos ainda palpitantes, testemunhando que a guerra terminara há pouco. Não eram de uma guerra comum os indícios que se viam, mas misturavam-se também com um banquete que não fora afortunado, mas terminara assim, em deploráveis restos: algumas mesas ainda estavam repletas de alimentos, outras no chão, nas mãos dos que jaziam, tendo servido, para alguns, como escudo na batalha, pois a guerra fora súbita (As etiópicas, I, I, 1-4).

Na obra de Heliodoro (como em toda epopéia em prosa), existem inúmeros relatos que entrecruzam a narração principal, e, para que não se perca a unidade da

${ }^{169}$ Brandão, J. L., A invenção do romance, op.cit., p.145. 
história, o narrador das Etiópicas guia seu leitor num labirinto de enredos, apresentando sempre uma saída: o retorno à trama central. Além disso,

orienta também a compreensão do leitor, embutindo na narrativa apreciações a seu respeito, tanto no que concerne à forma como se estrutura, quanto aos assuntos de que trata, seja diretamente (nas referências do narrador principal a técnicas da epopéia ou, sobretudo, do teatro), seja por meio de suas personagens narradoras. ${ }^{170}$

Se a Constante Florinda é uma epopéia em prosa publicada em Portugal, não poderíamos deixar de mencionar algumas características do narrador (que, voltamos a afirmar, não queremos confundir com o "poeta") d'Os Lusíadas, ${ }^{171}$ principal epopéia portuguesa, imitada e comentada, freqüentemente, no século XVII. Na narração desse poema épico, fica evidente aquela antiga tópica da poesia como imortalização dos heróis e de seus feitos. ${ }^{172} \mathrm{Na}$ verdade, n’ Os Lusíadas tem-se a impressão de que o personagem principal não é o herói Vasco da Gama, mas a persona que narra seus feitos. São muitos, e exaustivamente citados e comentados, os versos em que o narrador explicita o artifício (verossímil) do texto e mostra, como personagem gnarus, que conhece os preceitos e sabe usar as técnicas da ars narrandi. Lembremos, por exemplo, do conhecido trecho da proposição que, diferentemente dos poemas homéricos e seguindo a Eneida, é feita antes da invocação: "Cantando espalharei por toda parte, / Se a tanto me ajudar o engenho e arte" (I, 2). Versos que, como sabemos, ressoam o arma uirumque cano virgiliano. É curioso notar que tanto na epopéia de Virgílio como na de Camões, diversamente do que observamos na Ilíada e na Odisséia, a narração não se inicia com o pedido de auxílio às Musas, e sim colocando em evidência a persona que irá cantar a história.

Para não nos estendermos muito nessa questão, destaquemos apenas que, além do fato de que muitas das "falas" do narrador d'Os Lusíadas estejam em primeira

\footnotetext{
${ }^{170}$ Idem, p. 140.

171 Camões, Luís de. Obra Completa. Rio de Janeiro: Nova Aguilar, 2005. Citaremos o canto em algarismo romano, seguido do número da estância, em algarismo arábico, e do número da página correspondente a essa edição d'Os Lusíadas.

${ }^{172}$ Conforme as palavras de Curtius, "já os antigos heróis de Homero sabiam que a poesia dá glória eterna aos que celebra (Ilíada, VI, 359). A poesia imortaliza. Os poetas gostam de insistir sobre o fato; assim Teógnis (237 e ss.) lembra-o a seu Cirno, Teócrito (XVI) a seu Hierão, Propércio a sua Cíntia (III, 2, 17) e, sem destinatário certo, Horácio (Carm., IV, 8, 28). Ovídio também utiliza o argumento (Am., I, 10, 62)" (Literatura Européia e Idade Média Latina. Trad. Teodoro Cabral e Paulo Rónai. São Paulo: Hucitec; Edusp, 1996, p.579).
} 
pessoa, evidenciando sua presença (como acabamos de ver), ele também, assim como fará o narrador da Constante Florinda, quer legar aos seus leitores ou ouvintes ensinamentos sobre a difícil peregrinação que é a vida humana. Vida que, de infortúnios e enganos feita, é a morada do "bicho da terra tão pequeno":

Oh! Grandes e gravíssimos perigos,

Oh! Caminho de vida nunca certo,

Que aonde a gente põe sua esperança

Tenha a vida tão pouca segurança!

No mar tanta tormenta e tanto dano,

Tantas vezes a morte apercebida;

Na terra tanta guerra, tanto engano,

Tanta necessidade avorrecida!

Onde pode acolher-se um fraco humano,

Onde terá segura a curta vida,

Que não se arme e se indigne o Céu sereno

Contra um bicho da terra tão pequeno? ${ }^{173}$

Pois bem. Se nessas obras a que nos referimos, em especial nas epopéias em prosa antigas, ${ }^{174} \mathrm{o}$ narrador já se mostrava uma persona fundamental na estruturação dos textos, veremos que na Constante Florinda ele é ainda mais marcante e essencial para a compreensão da obra como um todo.

Antes de nos voltarmos ao nosso objeto de estudo propriamente dito, vale ressaltar que importantes reflexões sobre as questões narrativas na ficção em prosa antiga já foram feitas. Para exemplificar, podemos mencionar os trabalhos de Massino Fusillo ${ }^{175}$ e do já citado Jacyntho Lins Brandão. ${ }^{176}$ Entretanto, essas análises tendem a desconsiderar os preceitos das technai retórica e poética, baseando-se apenas em teorias

\footnotetext{
${ }^{173}$ I, $105-106$, p.33.

${ }^{174}$ Sobre esses textos em prosa antigos, é extensa a bibliografia. Mencionaremos apenas algunas estudos, além do já citado de Jacyntho Lins Brandão: Perry, B. E. The Ancient Romances: A Literary-Historical Account of Their Origins. Berkeley; Los Angeles: University of California Press, 1967; Gual, C. G. Los Orígenes de la Novela. Madrid: Istmo, 1972; Hägg, T. The Novel in Antiquity. Oxford; New York: Basil Blackwell, 1983.

${ }^{175}$ No estudo de Fusillo, há diversas discussões sobre a narração no "romanzo grego" (Naissance du roman. Traduit de l'italien par Marielle Abrioux. Paris: Seuil, 1991, pp.121-193).

${ }^{176}$ Praticamente todo o livro de Lins Brandão é dedicado às técnicas narrativas do "romance grego"; porém, há um longo capítulo que discute, em especial, a questão do "narrador" (A invenção do romance, op.cit., 91-156).
} 
contemporâneas do "narrador" e da "narração". Nosso trabalho, ao contrário, busca pautar o estudo por uma perspectiva retórico-poética, pois julgamos ser esta a mais adequada para se discutir tanto as epopéias em prosa antigas como as seiscentistas. ${ }^{177}$

Assim, nossa análise se foca nas duas partes que compõem a Constante Florinda, de Gaspar Pires de Rebelo. A primeira parte trata da peregrinação de Florinda que, acreditando estar morto seu amado, perambula sozinha pelo mundo, travestida de homem (autodenominando-se Leandro), para não se casar com nenhum outro e, assim, manter a palavra dada a seu querido Arnaldo. Já a andança deste em busca de sua amada Florinda é relatada apenas na segunda parte, escrita devido ao sucesso da primeira ${ }^{178} \mathrm{e}$ publicada oito anos depois. Em comum, os dois protagonistas viajam por diferentes partes do mundo e encontram os mais diversos personagens, que sempre têm uma história de vida, viciosa e desafortunada, para contar. Em contraposição aos viciosos, Florinda e Arnaldo são exemplos da mais perfeita virtude. Por isso, como recompensa, reencontram-se e casam-se no final dos Infortúnios trágicos da constante Florinda. Porém, a Segunda Parte da Constante Florinda vai um pouco mais além e dá conta, com detalhes, do que aconteceu com os dois amantes depois do reencontro: viveram juntos até que a morte, derradeiro infortúnio, encerrou suas vidas peregrinas.

Para começarmos a examinar a narração da Constante Florinda e, especificamente, a persona que narra a história de Florinda e Arnaldo, vale a pena retomar algo que já tínhamos mencionado. Aristóteles, no capítulo III da Poética, classifica três espécies de poesia, segundo seu modo de imitação. Quando o poeta fala sempre na própria pessoa, o poema é chamado "narrativo", como é o caso dos ditirambos e de quase toda poesia lírica; aqui também se encaixa o historiador, com a diferença de não apresentar as coisas por mimese. Agora, se o poeta nunca fala por si, fazendo falar diretamente somente os personagens, que é o que ocorre nas tragédias e nas comédias, o poema é dito "dramático". Por fim, falando tanto os personagens diretamente como o poeta na própria pessoa, o que temos é uma imitação mista ou

\footnotetext{
${ }^{177}$ Adma Muhana foi uma das poucas estudiosas a refletir sobre a narração da epopéia em prosa sob um ponto de vista retórico-poético (A epopéia em prosa seiscentista, op.cit., pp.233-264).

${ }^{178}$ É o autor que nos informa sobre tal sucesso, em seu "Prólogo ao leitor" da Segunda Parte da Constante Florinda: "Quanto ao que tive em fazer a primeira parte, foi somente por curiosidade e por dar alívio ao entendimento, que o molesta muito a lição contínua de uma ciência. Não pôde ser com tanta cautela, que não viesse à notícia de alguns amigos, e os mais deles letrados. Viram a obra honesta, e que assim de toda ela, como das histórias particulares que continha, se tiravam moralidades proveitosas, e de seus enredos pasto para os entendimentos curiosos, quasi por força a fizeram pública. E foi tão bem recebida, que em dous anos se gastou a impressão toda, e ao terceiro se tornara a imprimir, se não fora a falta que havia de papel". Assim, afirma que "esta segunda me foi pedida com muita instância" (op.cit., p.130).
} 
comum, como a que se dá na poesia épica. Com base nessa classificação aristotélica, repensada na preceptiva poética dos séculos XVI e XVII, podemos afirmar que a obra de Gaspar Pires de Rebelo "apresenta o exemplo mais comum de narrador das epopéias em prosa seiscentistas: aquele cujo ofício é tanto fazer falar seus personagens, como intervir diretamente sobre a narração, seja em primeira pessoa, seja em uma pessoa indefinida". ${ }^{179}$

Ao analisar esse narrador, não podemos esquecer que "la relación de la poética con la retórica es, por tanto, muy íntima: el terreno común para el poeta que compone y para el orador que ejerce es la mutua compenetración de ambas artes en los artistas creadores"; ou, ainda, que "la ilimitación objetiva de la retórica permite transferir todas sus técnicas a la poesía". ${ }^{180}$ No século XVII, um preceptista português, o já referido Manuel Pires de Almeida, diz algo nesse mesmo sentido: "e advirto, que tenho por impossível ser poeta sem o conhecimento da Retórica". ${ }^{181}$ Desse modo, no narrador da Constante Florinda que, como persona gnara, conhece a ars narrandi, encontraremos técnicas poéticas e procedimentos retóricos inventivos, dispositivos e elocutivos empregados na narração, mas que não permitem confudi-lo com um poeta ou com um orador.

Na abertura da primeira parte da Constante Florinda, há uma narração ab ovo, em que são expostas as origens da personagem principal: sua pátria e sua ascendência. Essa técnica narrativa não é a mais comum nas epopéias (tanto em verso como em prosa) e não é a mais recomendada pelas artes poéticas. ${ }^{182}$ No entanto, é possível relacioná-la com aquilo que sugerem algumas retóricas antigas para que a narratio seja clara, isto é, como já vimos quando tratamos dos preceitos de Quintiliano, a expositio deve apresentar uma nítida diferenciação das coisas, das pessoas, dos tempos, dos lugares e das causas, fazendo, assim, com que o juiz entenda o que se diz da maneira mais fácil possível (Inst. Orat., IV, II, 36). E é assim que o narrador age ao contar, detalhadamente, a história de Florinda desde o princípio (na verdade, antes mesmo do nascimento da personagem), diferenciando lugares, pessoas e causas, para facilitar a compreensão de seus leitores:

\footnotetext{
${ }^{179}$ Muhana, A.. A epopéia em prosa seiscentista, op.cit., p.89.

${ }^{180}$ Lausberg, H., Manual de Retórica Literária, op.cit., p.89.

${ }^{181}$ Discurso sobre o Poema Heróico, op.cit., fl. 634.

${ }^{182}$ É o que fica claro, por exemplo, no seguinte trecho de Horácio, no qual o autor recrimina a história contada ab ovo e preceitua que seja iniciada in medias res: "Nec reditum Diomedis ab interitu Melagri, / nec gemino bellum Troianum prditur ab ouo; / semper ad euentum festinat et in medias res / non secus ac notas auditorem rapit, et quae / desperat tractata nitescere posse relinquit" (Arte poética, vv.146-150).
} 
Em a muito nobre e populosa cidade de Saragoça, principal do Reino de Aragão, não só polos ilustres varões de que está povoada, altos edifícios e outras grandezas que a fazem digna de muita estima; senão também porque é fertilizada com as claras águas do rio Ebro, que com acelerado curso se vão desobrigar ao mar Oceano; houve um Cavaleiro chamado dom Flóris, igual aos mais nobres em sangue e aventejado de todos em vários bens e riquezas da vida, possuindo muitos, não só em algumas terras, que como senhor possuía, mas também gozando de ricas jóias e curiosas peças de outras estranhas de que o não era; e sobretudo de bons costumes e melhoradas virtudes, que estas partes são as que fazem ao homem ter muitas para ser de todos estimado e querido, como na verdade era este cavaleiro. Porque como fosse conhecido por homem limpo em sangue, atentado no regimento, acautelado em sua vida, experimentado já na idade, livre nas palavras, virtuoso nas obras, em a paz pacífico, em a guerra esforçado e liberal de seus bens pera com os pobres, e ajudava com eles a sustentar a fazenda dos mais ricos; não havia quem a sua pessoa sujeito não fosse, nem alguma que de sua amizade se isentasse. A este pois deram os Céus por esposa a uma mulher igual a ele em honra, virtudes e nobreza, a qual se chamava Aurélia. Os quais estiveram casados por alguns anos sem poderem haver filhos, pelo que viviam com assaz descontentamento e desconsolação; do qual davam claras mostras as contínuas lágrimas que corriam de seus olhos: porque como elas nasçam do íntimo do coração, donde toda a paixão e tristeza se recolhe, para que com a força dela não rebente, dão-lhe lugar e saem-se a dá-las do que padece. E como quer que lágrimas justas sempre são de Deus ouvidas e premiadas, apiedando-se destas lhes concedeu uma filha, em todo extremo bela e fermosa, e em todo ele deles estimada, à qual puseram nome Florinda: em cujo nascimento se fizeram muitas e grandes festas, em que se acharam todos os amigos e parentes que seu pai dom Flóris tinha, não só em a dita cidade, mas nas vilas circunvizinhas a ela. ${ }^{183}$

183 Infortúnios trágicos da constante Florinda, capítulo primeiro, pp.39-40. Para citar os trechos da primeira parte da obra de Gaspar Pires de Rebelo, utilizaremos a edição, já mencionada, de Adma Muhana. Mas consultamos também o texto da impressão de 1633 (Lisboa: António Álvares) e aquele da edição de 1761 (Lisboa: Na Officina de Francisco Borges de Sousa), além das edições contêmporâneas, já 
Já na Constante Florinda parte II, o narrador inicia a história in medias res, utilizando uma técnica bastante prestigiosa entre os autores antigos, tais como Homero, Virgílio e Heliodoro. Mas não apenas entre os antigos, pois em duas outras epopéias em prosa seiscentistas a narração também começa in medias res: em El peregrino en su patria, de Lope de Vega, ${ }^{184}$ e em Los trabajos de Persiles y Sigismunda, de Cervantes. ${ }^{185}$ A segunda parte da Constante Florinda tem seu princípio com uma cena de caça, em que surge um personagem misterioso, cuja relevância para a história dos infortúnios de Arnaldo irá se constituindo aos poucos, numa narrativa cheia de peripécias e de inesperados "reconhecimentos". ${ }^{186}$ Vale ressaltar, neste momento, que na narração da segunda parte da obra, as "falas" da persona que narra são menos freqüentes e menos diretivas do que na primeira parte; porém, a narração dos infortúnios de Arnaldo, em comparação àquela dos sucessos trágicos de Florinda, apresenta mais referências mitológicas e citações de "autoridades", o que a torna mais densa e "culta", como fica evidente no trecho que abre o texto:

Tempo era em que os mortais se levantavam com vida da escura e sossegada sombra da triste Átropos, deixando as duas companheiras tão sentidas, que foram buscar seu descanso em as entranhas do Averno Lago. Cuja presença fez ausentar de suas árvores tristes os passarinhos alegres, para que fossem lembrar à fermosa Circes que era já tempo de seu pai Febo passear por nosso Hemisfério, pois havia doze horas que estava em as Antípodas escondido. Quando pela costa de um monte que, na altura com o Monte Cásio competia,

referidas, de Artur Gonçalves (Lisboa: Universidade Nova de Lisboa, 2000) e Nuno Júdice (Lisboa: Teorema, 2005).

${ }^{184}$ Inicia-se desta forma El peregrino en su patria: "Salía sobre las brancas arenas de la famosa playa de Barcelona, entre unas cajas, tablas y rotas jarcias de un navío, un bulto de sayal pardo, cubierto de algas y ovas que visto de unos pescadores y puesto en una barca, con la codicia de que fuese alguna rica presa, fue llevado por la ribera abajo dos largas millas, hasta que entre unos verdes árboles desenvuelto, como las demás cosas, fue conocido por un hombre que entre la vida y la muerte estaba en calma" (Edición de Juan Bautista Avalle-Arce. Madrid: Castalia, 2006, p.69).

${ }^{185}$ A narração de Los trabajos de Persiles y Sigismunda também principia já no meio da ação: "Voces daba el bárbaro Corsicurvo a la estrecha boca de una profunda mazmorra, antes sepultura que prisión de muchos cuerpos vivos que en ella estaban sepultados, y, aunque su terrible y espantoso estruendo cerca y lejos se escuchaba, de nadie eran entendidas articuladamente las razones que pronunciaba sino de la miserable Cloelia, a quien sus desventuras en aquella profundidad tenían encerrada" (Edición de Carlos Romero Muñoz. Madrid: Cátedra, 2004, pp.127-128).

${ }^{186}$ Essa cena inicial e os demais acontecimentos do primeiro capítulo só serão devidamente esclarecidos no capítulo XIX, no qual o caçador (cujo nome é Flamiano) consegue terminar de contar a história de sua vida e explica por que estava caçando naquele lugar e naquele dia. 
vinha descendo um robusto mancebo com tanta ligeireza que à sua vista a fama dos celebrados passos de Atalanta ficava escurecida.

Moviam a tanta pressa a muita com que um ligeiro cervo pelo cimo das mais altas rochas se vinha despenhando, a quem uns sobejos cães vinham seguindo. $O$ qual se ao longe mostrava ser algum Salvagem de Cítia, que tendo os pés virados alcançam os animais ferozes, contudo ao perto parecia outro Policenes vistido em a pele do leão nemeu, que matara Hércules Tebano, ou Tideu coberto com a pele do javali, que tinha morto seu irmão Meleagro. Porque o vestido era de ũas hirtas peles ondeadas de várias cores, cujos quartos apertavam em meio uns visos negros, que nem por se verem maltratados pagavam com desconcertos, antes os faziam mais engraçados. Trazia arco em as mãos e aljava lançada ao ombro, e ele tão louro e bem corado, qual o roxo Apolo em o Monte Cíntio. ${ }^{187}$

Ao conduzir a história, é ofício do narrador, em termos retóricos, mouere, delectare e docere seus leitores. Sendo assim, no final do capítulo IV da primeira parte da obra, no momento em que Florinda fica sabendo da suposta morte de seu querido Arnaldo, há um trecho que exemplifica muito bem como é dirigida a narração:

E esforçando-se o criado ergueu do chão a Arnaldo, e vendo (ao que ele lhe parecia) que estava morto, chegando-se à grade não com poucas lágrimas o fez saber a Florinda, e tomando-o às costas o levou a sua casa. Ao qual deixemos (não se esquecendo o curioso leitor de notar e ter na memória estas palavras até seu tempo) e tornemos a Florinda, porque o principal intento do autor é contar os infortúnios trágicos de sua vida e sucessos dela (tudo por guardar fé e palavra a seu querido Arnaldo), que melhor lhe fora antes uma descansada morte, pois pelo discurso de tão trabalhosa vida mais se pode dizer que morreu do que viveu, porque uma vida que vivendo morre, é-lhe melhor e mais segura uma morte descansada. ${ }^{188}$

Nessas palavras, percebe-se um narrador meticuloso, que tem extremo cuidado com os detalhes do enredo e que deixa explícita sua preocupação em "atingir" seus

\footnotetext{
${ }^{187}$ Segunda parte da Constante Florinda, capítulo I, p.135.

${ }^{188}$ Infortúnios trágicos da constante Florinda, capítulo IV, pp.64-65.
} 
leitores. Observando-se o final da citação ("porque uma vida que vivendo morre, é-lhe melhor e mais segura uma morte descansada"), nota-se a presença de uma sentença ou adágio que encerra uma sabedoria de validez universal ${ }^{189}$ e que, além disso, corrobora a causa do narrador. Este quer persuadir seus leitores a se comoverem com a situação miserável de Florinda, que, peregrinando pelo mundo, passará por dificuldades incontáveis. Para tanto, termina o capítulo adiantando a comoção que causará a futura vida desafortunada da donzela, que logo em seguida começará sua infeliz perambulação. Portanto, de imparcialidade indubitável, tal sentença afeta o "curioso leitor".

Sobre esse arrebatamento afetivo, podemos lembrar que na retórica aristotélica os afetos são definidos como "as causas que fazem alterar os seres humanos e introduzem mudanças nos seus juízos, na medida em que (...) comportam dor e prazer" (Retórica, II, 1, 1378a); e, ainda de acordo com Aristóteles, o orador deve falar de forma a suscitar o pathos nos ouvintes (Idem, III, 16, 1417a). Tal necessidade de mover o auditório, provocando-lhe os afetos fica ainda mais patente no seguinte trecho de Cícero:

sic equidem quom adgredior in ancipiti causa et graui ad animos iudicum pertractandos, omni mente in ea cogitatione curaque uersor, ut odorer quam sagacissime possim quid sentiant, quid existiment, quid expectent, quid uelint, quo deduci oratione facillume posse uideantur.

(De Oratore, II, XLIV, 186).

Portanto, o mouere é essa capacidade de atingir o animus daqueles que julgam, escutam ou lêem. Desse modo, sendo um gênero poético-retórico, é ofício da epopéia em prosa dar aos leitores o que esperam, o que desejam, para que o discurso implícito no texto, deleitando e ensinando, possa penetrar nos "ânimos" e envolvê-los o mais fácil e agradavelmente possível. E assim age o narrador da Constante Florinda, no início do

\footnotetext{
${ }^{189}$ Com relação às sentenças, vale a pena lembrar o que afirma Baltasar Gracián, em sua Agudeza y Arte de Ingenio, discurso XXIX: "Las sentencias y las crisis sazonan la historia, que sin estos dos resabios es insula la narración, especialmente a gustos juiciosos, a profundas capacidades. Y aunque cualquiera sentencia es concepto, porque esencialmente es acto del discurso una verdad sublime, recóndita y prudente..." (op.cit., t.2, p.22). E continua: "No sólo sirven para concluir perfectamente un epigrama o un soneto estos conceptos sentenciosos, sino que en medio de una narración o discurso se dejan caer como perlas de la aurora, sobre las fragantes flores" (op.cit., t.2, p.29). Por fim, diz sobre a universalidade das sentenças: "Son verdades célebres las sentencias, cuando son universales" (op.cit., t.2, p.30).
} 
capítulo V, ao suscitar a piedade em seus leitores, ${ }^{190}$ através do "encarecimento" da dor da personagem principal, logo após a donzela ter por certa a fingida morte de Arnaldo:

Se pudera com meu fraco estilo encarecer a grande dor e sentimento que a fermosa Florinda recebeu com o sucesso já contado, aumentandose-lhe de novo quando no fim dele o criado de Arnaldo com mil lágrimas em seus olhos lhe deu a triste nova de sua morte (que ela sempre teve para si), manifestara a maior que nunca ocupou coração humano e não com pouca rezão; porque como o amor quanto é maior tanto maiores são seus efeitos, e o que tinha ligado os corações destes amantes fosse tam grande que não há pena que o declare, nem língua que o manifeste, de crer é que seus efeitos haviam de ser excessivos e grandes como no processo desta história se verá. ${ }^{191}$

O mouere, na epopéia em prosa seiscentista (conforme vimos na definição do termo), ocorre por meio de um misto entre delectare e docere; preceito esse que ecoa os famosos versos, já citados, de Horácio: "Omne tulit punctum qui miscuit utile dulci, / lectorem delectando pariterque monendo" (Arte Poética, vv.343-344). Na Segunda parte da Constante Florinda, como dissemos, a narração e, conseqüentemente, as "falas" da persona que narra são muito mais "cultas" e "ornadas", e para conseguir tal ornamentação percebe-se um predomínio do delectare em muitos trechos do texto; um deleite em que o ut pictura poesis é uma das principais técnicas utilizadas (não exatamente o ut pictura poesis horaciano, mas aquele já inserido nas discussões quinhentistas e seiscentistas), tornando-se o narrador êmulo dos pintores, pois, como já

\footnotetext{
${ }^{190}$ Sobre a incitação da compaixão e da piedade nos ouvintes, não há como deixar de mencionar, mais uma vez, aquilo que já vimos ao tratar, no capítulo 1, dos preceitos retóricos e poéticos da narração. Em Corte na Aldeia, de Francisco Rodrigues Lobo, um dos personagens (o "Doutor") faz o seguinte comentário a respeito da história contada por um outro personagem (o "Licenciado"): "Maravilhosa é a história para exemplo (disse o Doutor) e também poderá servir no como se devem contar outras semelhantes: com boa descrição das pessoas, relação dos acontecimentos, razão dos tempos e lugares e uma prática por parte de alguma das figuras que mova mais a compaixão e piedade; que isto faz dobrar depois a alegria do bom sucesso" (Corte na Aldeia e Noites de Inverno, op,cit., p.199). Merece ser recordada também uma outra coisa que afirmamos sobre o assunto: que as palavras do "Doutor" remontam, claramente, ao preceito aristotélico de que a tragédia deve provocar nos espectadores o terror e a piedade: "Como porém a tragédia não só é imitação de uma ação completa, como também a de casos que suscitam o terror e a piedade" (Poética, IX, 1452a, 1-2).

${ }_{191}$ Infortúnios trágicos da constante Florinda, capítulo V, p.66.
} 
mencionamos, afirma Manuel Pires de Almeida em seu tratado Poesia, e Pintura, ou Pintura, e Poesia, "quando se escreve se pinta, e quando se pinta, se escreve". ${ }^{192}$

$\mathrm{Na}$ segunda parte da Constante Florinda, Arnaldo, em suas andanças pelo mundo à procura de Florinda, foi para a França "e antes que chegasse à cidade de Avinhão, (...) viu um monte alto, cheio de muito arvoredo, ao qual subiu para que passasse aquele dia em as negras sombras contemplando suas tristezas". ${ }^{193}$ Nesse monte, viu uma fonte e, seguindo "um cano de pedra natural", foi descendo uns degraus de pedraria até entrar "em umas casas debaixo do chão fundadas, a quem servia de tecto a terra sustentada em grossas colunas, e a compasso certas aberturas que lhes comunicavam a claridade necessária". ${ }^{194}$ Ao perscrutar os cômodos dessas casas, Arnaldo ouviu as lamentações de um "triste queixoso" (cujo nome é Laureano, como ficaremos sabendo no capítulo seguinte). Curioso para saber quem se lamentava daquela maneira, Arnaldo entrou na pequena sala de onde partia o som e se deparou com um triste "quadro". O que nos interessa destacar nessa cena é como o narrador descreve minuciosamente as coisas, deleitando seus leitores por meio de uma elocução "colorida", ${ }^{195}$ para que eles apreciem a cena como se apreciacem uma pintura:

E porque é costume de um enfermo quando vê a outro do mesmo mal combatido querer certificar-se da causa donde procede, para se aproveitar de algum remédio que a experiência mostrasse ser de preceito, levado Arnaldo deste desejo (como bem necessitado), chegou a ũa porta, e não havendo resistência, entrou em uma pequena sala, porém aventajada às outras em a perfeição das pinturas. E buscando com os olhos o que desejava, viu a um homem reclinado em seus braços sobre ũa mesa de bem lavrada pedra. E porque as armas que tinha para se defender de seus inimigos mais eram para ser tratadas do engenhoso Timantes que do esforçado Ulisses, certo de que não fariam em eles o efeito de Alexandre Magno, tomou confiança para chegar mais perto, e tirando-lhe por um braço não deu acordo, cousa que o fez ser importuno, e aplicando a acção terceira, com maior força, teve o

\footnotetext{
${ }^{192}$ Há uma frase bastante parecida em Los trabajos de Persiles y Sigismunda: "La historia, la poesía y la pintura simbolizan entre sí y se parecen tanto que, cuando escribes historia, pintas y, cuando pintas, compones" (op.cit., p.570).

193 Segunda parte da Constante Florinda, capítulo XXVII, p.390.

${ }^{194}$ Idem,ibidem, p.391.

195 Vale lembrar o que diz Manuel Pires de Almeida: "O mesmo é cor na pintura que locução na poesia, e assim como na pintura não basta rascunho sem cor, assim na poesia não basta fábula sem locução" (Poesia e pintura, ou, Pintura e poesia, op.cit., p.103).
} 
efeito que intentava, porque logo desatou o rosto dos grilhões de seus braços aonde as cordas de suas tristezas o tinham preso, o qual bem mostrava quanto os ferros dos cuidados o tinham maltratado, porque dando-se suas feições por obrigadas à natureza por serem ornadas de prefeição e graça, e ao Céu agradecido de lhes dar ofício de pregoeiras de um engenho agudo, de um entendimento claro, de uma condição boa, de um natural bem inclinado, e sobretudo ser amante firme, verdadeiro e de pensamento altivo; o bem tirado campo aonde estavam plantadas denunciava queixas da fortuna, porque the tinha furtado o sol, de quem recebia a cor antiga que lhe dava maior graça, deixando-lhe a invernada das lágrimas que cada hora experimentava, que por não guardarem o tempo devido o tinham já tão desfigurado, que parecia de mais anos do que lhe tinham dado os tempos. ${ }^{196}$

Porém, na epopéia em prosa seiscentista, o deleite quase sempre está acompanhado do ensinamento, sendo, portanto, função do narrador agradar e instruir ao mesmo tempo, ${ }^{197}$ como é possível perceber no seguinte episódio da primeira parte da obra de Gaspar Pires de Rebelo. Em sua perambulação pelo mundo, Florinda (na verdade, Leandro, pois é quase sempre como homem que peregrina pelos mais diversos lugares), durante sua estadia em Bolonha, acabou se envolvendo numa disputa de letrados na Universidade da referida cidade, devido à fama de sábio que adquiriu através do estudo: "o nosso Leandro se deu a ler muitos e vários livros humanos, e tanto aproveitou em eles que antes do ano acabado era já de todos por sábio conhecido". 198 Tornou-se um exímio conhecedor de sentenças, "pera com elas mais ornar suas palavras", ${ }^{199}$ chegando até mesmo a ser chamado, por antonomásia, de "o estrangeiro sentencioso". Porém, o que queremos destacar é o que o narrador diz ao final do capítulo com relação à disputa que ocorrerá na Universidade:

E como tal (já quase no fim do ano) foi escolhido pera umas festas que certos Doutores da Universidade faziam. As quais por serem proveitosas ao entendimento me pareceu bem pôr aqui o teor delas.

\footnotetext{
${ }^{196}$ Segunda parte da Constante Florinda, capítulo XXVII, p.209-210

${ }^{197}$ Recordemos dos versos de Horácio: "Omne tulit punctum qui miscuit utile dulci, / lectorem delectando pariterque monendo" (Arte Poética, vv.344-343).

${ }_{198}$ Infortúnios trágicos da constante Florinda, capítulo X., pp.104-105.

${ }^{199}$ Idem, ibidem, p. 105.
} 
Porque as cousas que causam proveito é bem que se digam: pera que, enquanto se manifestam, aquelas que são alheias dele se encubram. ${ }^{200}$

Nessa citação, fica nítida a preocupação do narrador (externada na primeira pessoa, "me pareceu bem") de contar as coisas que sejam proveitosas ao entendimento, isto é, aquelas que possam vir a ensinar algo aos leitores. No capítulo seguinte, ele dá conta das tais festas. Percebemos, então, que a instrução vem acompanhada do deleite; isso fica patente logo na escolha dos cinco letrados:

um Teólogo em ditos dos padres muito visto, e um Filósofo humanista que era o segundo lido em sentenças de Filósofos. O terceiro, um latino prático em ditos sentenciosos. O quarto foi o nosso Leandro, escolhido por sentencioso. O quinto era um Espanhol mui dado a ditos graciosos como adágios e outros com que em sua conversação movia a riso. ${ }^{201}$

A variedade dos participantes e dos ditos garante que a disputa seja agradável aos leitores e, conseqüentemente, não deixa que estes se sintam entediados, sendo bastante divertida nos momentos em que o Espanhol profere seus adágios graciosos. ${ }^{202}$ Os ditos deveriam versar sobre algumas palavras escolhidas no decorrer do certame, tais como amor, amigo, adulação, amante etc. E são proveitosas as sentenças, enfim, porque aparecem como repositório eloqüente do saber, em frases elaboradas que não somente carregam um sentido moral, mas ainda atingem o ânimo dos leitores por sua condensação e agradam pela brevidade.

Tal proveito das sentenças também se evidencia num episódio de Los trabajos de Persiles y Sigismunda. No primeiro capítulo do livro IV, os dois amantes, acompanhados de alguns outros personagens que conheceram durante suas viagens, "llegaron una jornada antes de Roma y, en un mesón, adonde siempre les solía acontecer maravillas, les aconteció ésta, si es que así puede llamarse". ${ }^{203}$ Nessa hospedaria, um peregrino se aproximou deles com um cartapácio nas mãos e lhes explicou por que peregrinava com aquele caderno de notas:

\footnotetext{
${ }^{200}$ Idem, ibidem, p. 105.

${ }^{201}$ Idem, capítulo XI, p.106.

${ }^{202}$ Sobre as frases jocosas que o orador pode introduzir em seus discursos, Cícero afirma que essa capacidade de fazer gracejos é muito útil, mas que não pode ser ensinada, pois se trata de um dom natural: "Suavis autem est et uehementer saepe utilis iocus et facetiae; quae, etiam si alia omnia tradi arte possunt, naturae sunt propria certe neque ullam artem desiderant" (De Oratore, II, LIV).

${ }^{203}$ Los trabajos de Persiles y Sigismunda, op.cit., p.630.
} 
Este traje de peregrino que visto (el cual trae consigo la obligación de que pida limosna el que lo trae), me obliga a que os la pida, y tan aventajada y tan nueva que, sin darme joya alguna ni prendas que lo valgan, me habéis de hacer rico. (...) Y como la necesidad, según se dice, es maestra de avivar los ingenios, este mío, que tiene un no sé qué de fantástico e inventivo, ha dado en una imaginación algo peregrina y nueva y es que, a costa ajena, quiero sacar un libro a luz, cuyo trabajo sea, como he dicho, ajeno y, el provecho, mío. El libro se ha de llamar Flor de aforismos peregrinos; conviene a saber, sentencias sacadas de la misma verdad, en esta forma: cuando, en el camino o en otra parte, topo alguna persona cuya presencia muestre ser de ingenio y de prendas, le pido me escriba en este cartapacio algún dicho agudo, si es que le sabe, o alguna sentencia que lo parezca, y, de esta manera, tengo apuntados más de trecientos aforismos, todos dignos de saberse y de imprimirse, y no en nombre mío, sino de su mismo autor, que lo firmó de su nombre después de haberlo dicho. Ésta es la limosna que pido y la que estimaré sobre todo el oro del mundo. ${ }^{204}$

Nessa fala do peregrino, fica nítido o "valor" das sentenças, merecendo serem impressas aquelas que sejam mais "preciosas". O título do livro, Flor de aforismos peregrinos, mostra que não são apenas úteis os aforismos, mas também deleitosos, na medida em que suscitam a graça e a beleza das flores. Os dois amantes, Periandro e Auristela (cujos nomes verdadeiros são Persiles e Sigismunda), e seus companheiros de viagem atendem ao pedido do peregrino e lhe dão a referida "esmola". É importante destacar que há um decoro entre as sentenças e o "caráter",205 dos personagens que as proferem. Auristela (na verdade, Sigismunda), por exemplo, explicita seu ethos na sentença que escreve no cartapácio do peregrino: "La mejor dote que puede llevar la mujer principal es la honestidad, porque la hermosura y la riqueza el tiempo la gasta o

\footnotetext{
${ }^{204}$ Idem, pp.631-632.

205 Quando falamos em "caráter" pensamos no ethos de cada personagem, ou seja, seu habitus, sua maneira de se comportar. É o que encontramos, por exemplo, nos Caracteres de Teofrasto: cada caráter é definido pelo seu modo de agir (Os caracteres. Introdução, tradução e comentários de Daisi Malhadas e Haiganuch Sarian. São Paulo: E.P.U., 1978). Ou ainda, como bem explica Cipión, um dos cães do Coloquio de los perros, uma das Novelas Ejemplares de Cervantes: "Las honestas palabras dan indicio de la honestidad del que las pronuncia o las escribe" (Novelas ejemplares II. Edición de Hary Sieber. Madri: Cátedra, 2005, p.319).
} 
la fortuna la deshace ${ }^{206}$ Esse caráter da personagem se aproxima muito daquele de Florinda, sendo ambas exemplos da mais perfeita honestidade ao enfrentar diversos perigos e infortúnios para se manterem honradas e fiéis aos seus amados. Esse decoro entre a sentença e o caráter torna-se ainda mais evidente no aforismo que o peregrino cita de memória para deleite e proveito de seus ouvintes: "No desees y serás el más rico hombre del mundo. Y la firma decía: 'Diego de Ratos, corcovado, zapatero de viejo en Tordesillas, lugar en Castilla la Vieja, junto a Valladolid"”. Por isso, no início do capítulo seguinte, o narrador afirma que tal livro de ditos alheios poderia muito bem se intitular "Historia peregrina sacada de diversos autores, y dijera verdad, según habían sido y iban siendo los que la componían". ${ }^{207}$ Ou seja, com as sentenças se compõem os personagens e a própria história.

Para continuar analisando o narrador da Constante Florinda, vale recordar que a maior parte dos tratados de retórica preceitua que são três as principais qualidades da narração: clareza, brevidade e verossimilhança; como vimos, especialmente, na Rhetorica ad Herennium e na Institutio Oratoria.

$\mathrm{Na}$ primeira parte da obra de Gaspar Pires de Rebelo, temos inúmeros exemplos de como o narrador se preocupa, explicitamente, com a clareza de sua expositio (que, insistimos em ressaltar, é diferente da expositio de um orador, embora sejam utilizadas técnicas semelhantes). No entanto, é preciso lembrar antes que a clareza da narratio se refere tanto à matéria (res) quanto às palavras (uerba), como já tínhamos destacado, por exemplo, nos preceitos de Quintiliano: uma narração clara é aquela em que há não apenas o uso de palavras próprias ou adequadas, mas também uma nítida diferenciação das coisas, das pessoas, dos tempos, dos lugares e das causas; tudo para que o "juiz" entenda o que é narrado da maneira mais fácil possível (Inst. Orat., IV, II, 36). Antes de Quintiliano, porém, na Rhetorica ad Herennium está ainda mais evidente que a clareza da narração não depende somente das palavras empregadas:

Narraremos de modo claro se expusermos em primeiro lugar aquilo que tiver acontecido primeiro e conservarmos a ordem cronológica dos acontecimentos tal como tiverem ocorrido ou como parecerão ter ocorrido. Aqui, devemos cuidar de não discursar de modo confuso, obscuro, inusitado; não passar a outro assunto; não começar de muito

\footnotetext{
${ }^{206}$ Idem, p.633.

${ }^{207}$ Idem, p.636.
} 
longe, não seguir muito adiante e não deixar de lado o que diz respeito à matéria (Rhetorica ad Herennium, I, 15). ${ }^{208}$

Portanto, com base nesses preceitos sobre a clareza da narração é que examinaremos os procedimentos da persona que narra a Constante Florinda: estamos interessados em mostrar, principalmente, o modo como ela organiza e dispõe as coisas narradas. Dessa forma, também se evidenciará a tensão, que o narrador explicita freqüentemente para o leitor, entre o arbitrário da direção narrativa e a motivação verossímil da fábula; tensão essa provocada pela dificuldade de contar os infortúnios trágicos de Florinda e Arnaldo de maneira variada, inserindo episódios e peripécias que não devem impedir o prosseguimento da narração daqueles infortúnios.

Para começar, mencionaremos um caso, talvez o mais significativo, em que é salientado o cuidado extremo com a condução da narração, para que, sendo esta clara, os leitores não se percam nos incontáveis "desvios" da história. No capítulo V, Florinda, depois de julgar morto seu querido Arnaldo, decidiu partir pelo mundo em trajes de homem, para manter a palavra dada a seu amado e não se casar com nenhum outro. Para cumprir tal intento, precisava de roupas adequadas, isto é, masculinas; assim,

logo mandou chamar secretamente certa mulher que vendia pela cidade toda a sorte de vestidos, e achando entre eles um mais lhe contentou, fingindo ser para um primo seu que havia de vir de fora, não reparando em o preço, com as mais alfaias que lhe pareceu eram necessárias (de que adiante faremos menção) se passou o dia sem dar conta à pessoa alguma do que intentava. ${ }^{209}$

Nesse trecho, o narrador promete dar conta dos trajes que Florinda escolheu para si ("de que adiante faremos menção") e cumpre a promessa no final do capítulo, após contar como a donzela, já vestida de homem, matou dom Luís, para vingar a suposta morte de Arnaldo. Só depois de todo esse "excurso" é que empreende a esperada descrição dos trajes de Florinda, não sem antes deixar bastante claro que vai

\footnotetext{
${ }^{208}$ A tradução citada é a de Ana Paula Celestino Faria e Adriana Seabra (Retórica a Herênio, op.cit., p.67-69).

${ }^{209}$ Infortúnios trágicos da constante Florinda, capítulo V, p.67.
} 
cumprir o que prometeu (transcreveremos todo o longo trecho, pois também exemplifica como o narrador "põe diante dos olhos" ${ }^{\text {210 }}$ de seus leitores aquilo que descreve):

E porque prometemos de dar conta do vestido que levava e mais peças, me pareceu fazê-lo agora, em quanto ela, ou para melhor dizer, ele (que já se tinha posto a si mesmo nome, para passar por tal até a fortuna dispor outras cousa, o qual era Leandro, que por este o trataremos daqui em diante), cansado já de derramar lágrimas se havia recostado sobre o coxim da sela a dar algum descanso a seu corpo. Era pois o vestido de um pano muito fino azul e amarelo todo golpeado, tomado o remate dos miúdos golpes com uma mosca de fino ouro, e um botão de prata que às vezes preso em um alamar do mesmo o cerrava e, quando aberto, descobria o forro que era de cetim aleonado, que mais graça dava aos golpes de que todo o vestido estava cheio. Debaixo do qual vestia um jubão de corte verde com passamanes de prata entressachada de ouro e tão miúdos que mal davam lugar que o verde por entre ele se divisasse. Um chapéu pardo com plumas brancas, verdes e negras, com um trancelim de fino ouro e por remate um fermoso diamante (peça que o pai tinha em dous mil cruzados). Levava mais uma cadeia de ouro com os fuzis esmaltados de branco, sobraçada em os ombros com sua espada e adaga, com terços de prata dourada e brincada de esmaltes vários; e em dinheiro levava, afora o que tinha já gastado, setecentos cruzados em ouro e prata, e outras peças miúdas que ocupavam pouco e eram de valia. $^{211}$

É nesse momento também que o narrador cita pela primeira vez o nome Leandro, avisando aos leitores que assim chamará Florinda durante quase toda a história; mais exatamente, até o capítulo XXXI, no qual a donzela, que se viu obrigada a revelar sua condição de mulher, volta a ser chamada pelo seu verdadeiro nome. ${ }^{212}$

$\mathrm{Na}$ segunda parte da Constante Florinda, a persona que narra continua a se empenhar para que a narração seja clara. É o que se verifica, por exemplo, quando o

\footnotetext{
${ }^{210}$ A esse respeito, Aristóteles afirma na Poética: "Deve pois o poeta ordenar as fábulas e compor as elocuções das personagens, tendo-as à vista o mais que for possível, porque desta sorte, vendo as coisas claramente, como se estivesse presente aos mesmos sucessos, descobrirá o que convém e não lhe escapará qualquer eventual contradição" (XVII, 1455a, 22-26).

${ }^{211}$ Infortúnios trágicos da constante Florinda, capítulo V, pp.72-73.

212 "Despois que a nossa constante Florinda se viu já de todo descoberta e conhecida..." (Idem, capítulo XXXI, p.250).
} 
foco principal da narração é alterado. Até o capítulo XIII, os leitores acompanham, exclusivamente, as aventuras do caçador (que surgiu, repentinamente, na já mencionada cena inicial do texto); apenas no capítulo XIV é que Arnaldo se dá a conhecer e, aí sim, o foco narrativo se volta para o enredo principal: os infortúnios de Arnaldo em busca de Florinda. No começo da história, o caçador se depara com misteriosas frases entalhadas em pedras e em troncos de árvores. Seguindo-as, ele chega a uma torre, na qual ouve os lamentos de um homem desventurado, que se queixa por ter tão distante de si seu maior bem: sua amada. Nesse momento, o caçador é surpreendido por uma donzela com a qual estabelece um engenhoso diálogo; ela acaba conduzindo-o até a torre e leva-o diante daquele mancebo que ele tinha escutado se queixar. Para satisfazer a curiosidade de seus ouvintes, o caçador principia o relato dos sucessos de sua vida, que é interrompido, bruscamente, pela voz de um homem que batia à porta da torre, dizendo que tinha uma carta de muita urgência para o rapaz queixoso. Este leu a carta e, logo em seguida, partiu rapidamente. Depois disso, cinco homens com "escopetas" invadiram a torre à procura de um mancebo e de uma donzela, que julgaram ser aquela que tinha conduzido o caçador até ali. Para defender a moça, o caçador, que já estava apaixonado por ela, matou um dos homens com uma flechada; porém, quando armou novamente seu arco, "lhe deu um deles com dous pilouros pelo ombro esquerdo, e com a grande dor caiu em terra e, ainda que não morto, de todo desacordado". 213 Quando voltou a si, não havia mais ninguém na torre e decidiu, então, partir, mas acabou sendo preso quando ia "seguindo seu caminho, por uma piquena costa que ao pé do monte estava". ${ }^{214} \mathrm{Da}$ prisão, foi mandado para um degredo de três anos em Mallorca. Porém, o navio que o levava para o degredo foi atacado por embarcações de mouros, e o caçador foi mandado, como cativo, para Tagda. Nessa cidade, ao conversar com um outro cativo, reconhece ser este aquele mancebo que se lamentava na torre. Os leitores ficam sabendo, então, que o rapaz era Arnaldo, que se queixava pela ausência de Florinda, e somente a partir daí é que o foco da narração se volta para os infortúnios do protagonista.

Para destacar que tal momento é decisivo no enredo e deixar evidente que dali em diante Arnaldo será o fio condutor da trama, alerta o narrador: "Note o curioso Leitor que aqui entra a força de toda a história". ${ }^{215}$ Portanto, numa frase como essa, fica

\footnotetext{
${ }^{213}$ Segunda parte da Constante Florinda, capítulo IV, p.145.

${ }^{214}$ Idem, capítulo V, p. 146.

${ }^{215}$ Idem, capítulo XIV, p. 172.
} 
patente a preocupação com a clareza da narração, ordenando-se adequadamente os acontecimentos e salientando-se aquilo que diz respeito à matéria narrada, como se recomenda na Rhetorica ad Herennium, para que a "força da história" atinja e afete os leitores.

O cuidado da persona que narra com a clareza de sua exposição é ainda mais explícito no trecho que marca o ponto em que se cruzam os enredos das duas partes da obra. A primeira termina com o reencontro de Florinda e Arnaldo, que se casam e se tornam duquesa e duque de Florença. Quando a segunda parte chega a esse mesmo momento da história, diz o narrador:

E porque em ela ${ }^{216}$ não demos conta das circunstâncias do fim que tiveram estes amantes tão firmes, que os impediram solícitos desejos de alguns curiosos, agora que instâncias suas oferecidas de novo fizeram tirar a público os trágicos de Arnaldo, diremos brevemente do mais que passaram e do fim que ambos tiveram. ${ }^{217}$

A própria narração esclarece e reaviva na memória dos leitores as relações entre as duas partes da obra, cujos complexos enredos se tornam ainda mais complicados quando um faz referência ao outro, como na Constante Florinda parte II. Assim, como um bom contador de histórias, que sabe empregar as técnicas retóricas e poéticas, o narrador não quer que seus leitores esqueçam o que já foi dito, para que não se torne incompreensível o que se dirá.

No entanto, esse trecho citado também pode ser relacionado com uma outra qualidade essencial da narração: a brevidade. ${ }^{218} \mathrm{Se}$ o narrador tivesse que dizer novamente, na segunda parte, tudo o que já foi contado na primeira, a narração se tornaria extensa em demasia, repetitiva e, possivelmente, entediaria os leitores. Afinal, conforme observamos num dos preceitos da Rhetorica ad Herennium, para se conseguir narrar brevemente, "deve-se tomar cuidado para não dizer a mesma coisa duas ou mais vezes; também não devemos repetir o que acabamos de falar". ${ }^{219}$

\footnotetext{
${ }^{216}$ Ou seja, na primeira parte da obra.

${ }^{217}$ Segunda parte da Constante Florinda, capítulo XLV, p.264.

${ }^{218}$ Com relação à brevidade, além de tudo o que já dissemos, há também os comentários de Curtius em “A brevidade como ideal estilístico" (Literatura Européia e Idade Média Latina, op.cit., pp.595-604).

${ }^{219}$ Utilizamos a tradução de Ana Paula Celestino Faria e Adriana Seabra, op.cit., do seguinte trecho (que já mencionamos): "Et ne bis aut saepius idem dicamus, cauendum est; etiam ne quid, nouissime bquod diximus, deinceps dicamus" (Rhetorica ad Herennium, I, 14).
} 
Para refletirmos sobre a brevidade que deve ter a narração, é de extrema utilidade o longo relato que faz Periandro de alguns sucessos de sua vida, em Los trabajos de Persiles y Sigismunda. Tal relato do protagonista é exemplar, na medida em que os demais personagens, que estão a ouvi-lo, funcionam como "críticos" e fazem comentários muito interessantes sobre a "arte de narrar". Periando começa sua história in medias res, contando como ele e sua "irmã" foram parar numa ilha, onde assistiram às bodas de uns pescadores. Durante a celebração, surgem uns salteadores que roubam as noivas e Auristela, a suposta irmã de Periandro (como já dissemos, Periandro e Auristela são, na verdade, Persiles e Sigismunda; os dois, utilizando aqueles nomes falsos, se passam por irmãos durante praticamente toda a história; só no final, quando chegam a Roma, revelam suas verdadeiras identidades). Com relação à brevidade que deve ter a narração, em especial, o relato desses acontecimentos iniciais, contados largamente por Periandro, recebe uma crítica bastante significativa de um de seus ouvintes (Mauricio), que fala, sorrateiramente, para uma outra personagem (Transila):

Paréceme, Transila, que con menos palabras y más sucintos discursos pudiera Periandro contar los de su vida, porque no había para qué detenerse en decirnos tan por estenso las fiestas de las barcas, ni aun los casamientos de los pescadores, porque los episodios, que para ornato de las historias se ponen, no han de ser tan grandes como la misma historia. Pero yo, sin duda, creo que Periandro nos quiere mostrar la grandeza de ingenio y la elegancia de sus palabras. ${ }^{220}$

Essa crítica de Mauricio suscita uma questão fundamental para a constituição da epopéia em prosa seiscentista: a relação entre unidade e extensão. Sobre tal relação, afirma Aristóteles no capítulo VIII da Poética:

Por conseguinte, tal como é necessário que nas demais artes miméticas una seja a imitação, quando o seja de um objeto uno, assim também o mito, porque é imitação de ações, deve imitar as que sejam unas e completas, e todos os acontecimentos se devem suceder em conexão tal que, uma vez suprimido ou deslocado um deles, também se confunda ou mude a ordem do todo. Pois não faz parte de um todo, o que, quer seja quer não seja, não altera esse todo (1451a, 49).

\footnotetext{
${ }^{220}$ Los trabajos de Persiles y Sigismunda, op.cit., p.372.
} 
No mesmo sentido, aconselha Horácio: "Denique sit quod uis, simplex dumtaxat et unum" (Arte Poética, v.23). Na preceptiva poética dos autores quinhentistas e seiscentistas também encontramos recomendações semelhantes a essas dos antigos, mas, valorizando-se mais a epopéia (ao contrário de Aristóteles, que exaltava mais a tragédia), nos séculos XVI e XVII, a multiplicidade de episódios contida na ação principal é o que determina a superioridade da fábula épica. Nas duas partes da Constante Florinda, por exemplo, o que não falta é a multiplicidade de histórias secundárias ou "extravagantes". No "Prólogo ao leitor" da primeira parte, o próprio autor explica qual é a ação principal do texto e a função de seus variados episódios:

O que contém o presente volume são uns Infortúnios Trágicos que uma donzela passou pelo mundo por cumprir a palavra e fé que a seu amante tinha dado, e do que alcançou pela guarda dela. Vão mais algumas histórias extravagantes metidas em o enredo da que contém o livro, do qual não dou mais larga conta, porque, como são historias com que recebe deleitação o entendimento, nunca lhe causam tanta quando se dá miúda conta delas ao principio, que as cousas então são mais gostosas quando menos esperadas. ${ }^{221}$

Portanto, os episódios estão no livro para deleitar o entendimento, ou seja, agradar ensinando. Mas não só. Construtivamente, eles são antes de tudo funcionais. Como já destacamos, segundo Manuel Pires de Almeida, os "desvios" da ação principal (episódios ou parergos digressivos) nascem e dependem dela. ${ }^{222}$ Nesse sentido, vale a pena citar mais uma vez o trecho que dá início à narração da segunda parte da Constante Florinda:

Tempo era em que os mortais se levantavam com vida da escura e sossegada sombra da triste Átropos, deixando as duas companheiras tão sentidas, que foram buscar seu descanso em as entranhas do Averno Lago. Cuja presença fez ausentar de suas árvores tristes os passarinhos alegres, para que fossem lembrar à fermosa Circes que era já tempo de seu pai Febo passear por nosso Hemisfério,

${ }^{221}$ Infortúnios trágicos da constante Florinda, pp.34-35.

${ }^{222}$ Poesia e pintura, ou, Pintura e poesia, op.cit., p.100. 
pois havia doze horas que estava em as Antípodas escondido. Quando pela costa de um monte que, na altura com o Monte Cásio competia, vinha descendo um robusto mancebo com tanta ligeireza que à sua vista a fama dos celebrados passos de Atalanta ficava escurecida.

Moviam a tanta pressa a muita com que um ligeiro cervo pelo cimo das mais altas rochas se vinha despenhando, a quem uns sobejos cães vinham seguindo. $O$ qual se ao longe mostrava ser algum Salvagem de Cítia, que tendo os pés virados alcançam os animais ferozes, contudo ao perto parecia outro Policenes vistido em a pele do leão nemeu, que matara Hércules Tebano, ou Tideu coberto com a pele do javali, que tinha morto seu irmão Meleagro. Porque o vestido era de ũas hirtas peles ondeadas de várias cores, cujos quartos apertavam em meio uns visos negros, que nem por se verem maltratados pagavam com desconcertos, antes os faziam mais engraçados. Trazia arco em as mãos e aljava lançada ao ombro, e ele tão louro e bem corado, qual o roxo Apolo em o Monte Cíntio. ${ }^{223}$

Nesse quadro, que compõe uma unidade episódica fechada de espaço-tempo, é evidente o recurso a tópicas antigas e, em particular, aos livros de emblemas. Na descrição do robusto mancebo que desce o monte, retoma-se a imagem do miserável habitante da região cítia (a antiga Scythia), como vemos, por exemplo, no Emblema XXXVII de Alciato: Omnia mea mecum porto. ${ }^{224}$ Nele, o pobre Hunnus, Scythicique miserrimus accola Ponti, é tão desprovido de tudo que nada lhe pode fazer mal. Ele não teme ladrões, nem ventos, nem chuvas: está salvo (tutus) entre os homens e entre os deuses. Assim, essa cena que abre a segunda parte da Constante Florinda exemplifica um procedimento recorrente na narração dos infortúnios de Florinda e Arnaldo: os quadros, unidades episódicas que entrecruzam a ação principal, são ecfrases de emblemas em que há um embutimento de histórias dentro da história; a narração dessas ecfrases torna o texto acidentado e suspende o relato principal, obrigando o narrador a retomar aquilo que é o centro do enredo: as desventuras de Florinda e Arnaldo. E tal procedimento é explicitado muitas vezes aos leitores, como vimos quando tratamos da clareza da narração da Constante Florinda e veremos quanto à sua brevidade.

\footnotetext{
${ }^{223}$ Segunda parte da Constante Florinda, capítulo I, p.135.

${ }^{224}$ Citamos o emblema com base na seguinte edição bilíngüe: Emblemas. Edición y comentario de Santiago Sebastián; prólogo de Aurora Egido; traducción actualizada de los Emblemas de Pilar Pedraza. $2^{\mathrm{a}}$ ed. Madrid: Akal, 1993, p.72.
} 
Mas, enfim, com relação ao limite dessa multiplicidade de episódios, ou quanto à extensão ou grandeza do poema épico, a única determinação é que não seja tão pequeno como a tragédia ou a comédia, sendo a definição de seu tamanho incumbência da prudência do poeta e do decoro da imitação. Afinal, "tanto quanto as palavras e os caracteres devem ser apropriados à matéria do poema, os episódios devem ser próprios e convenientemente unidos à ação principal, de modo que a proporção mútua favoreça a irrupção dos afetos e favoreça o seu entendimento". 225

Desse modo, retomando a mencionada fala de Mauricio em Los trabajos de Persiles y Sigismunda, nota-se que o equilíbrio entre a extensão e a unidade da história depende da cautela do que narra; para Mauricio, Periandro exagerou ao contar os sucessos de sua vida e poderia ter feito o relato com menos palavras e discursos mais sucintos, ou seja, deveria ter sido mais breve. E essa preocupação com a brevidade da narração também se evidencia no texto da Constante Florinda.

Tanto na primeira como na segunda parte da obra de Rebelo, são inúmeros os momentos em que o narrador diz, expressamente, que vai evitar "palavras" ou a “prolixidade". Não há como esquecermos, a esse respeito, que no diálogo IX da Corte na Aldeia, uma das cinco advertências para quem deseja falar bem é justamente "fugir da prolixidade", como demonstramos anteriormente. Desse modo, vejamos alguns trechos em que o narrador anuncia que prezará a brevidade.

Num episódio da primeira parte, Leandro (que, como sabemos, é o "disfarce" de Florinda), depois de fugir de Bolonha, acaba sendo preso por um desconhecido, mas é salvo por duas mulheres, que o levam a um castelo. Neste, conhece quatro irmãs (Gracinda, Leonora, Cassandra e Gerarda) que, devido ao seu comportamento vicioso, foram ali encarceradas pelo pai. Uma das donzelas, Gracinda, desde o primeiro instante se apaixonou por Leandro. Após cada uma contar sua história desafortunada para o suposto rapaz, decidem mostrar-lhe todo o castelo. Nesse momento, o narrador interrompe a narração e diz o seguinte:

E por evitarmos palavras e abreviarmos histórias, é de saber que esteve Leandro mais três dias em o castelo, em todo extremo de toda a gente dele regalado, e como Gracinda fazia muitos por lhe descobrir seu

${ }^{225}$ Muhana, A. A epopéia em prosa seiscentista, op.cit., p.229. 
peito, determinou-se de o fazer uma menhã antes que ele saísse de seu aposento. ${ }^{226}$

Logo em seguida, Gracinda se declara a Leandro, mas este partiu do castelo no dia seguinte, para não provocar maiores confusões e sofrimentos. No trecho citado, fica evidente que o narrador visa a uma narração breve, não contando aquilo que é alheio ou inútil à sua "causa", para não perder o leitor pelo "tédio" (nos termos de Quintiliano). A brevidade é também sua principal preocupação num outro episódio, no qual Leandro encontra alguns pastores e decide morar com eles. Para não perder tempo descrevendo tudo pelo que o "mancebo" passou entre os pastores, o narrador avisa ao leitor que irá direto ao que interessa ao enredo: relatar os infortúnios de Florinda, e não a tranqüilidade e a felicidade de sua vida pastoril.

E por evitarmos prolixidade, é de saber que aqui esteve Leandro levando a vida comũa de todos com muito contentamento, sem lhe dar pena de amor algum desgosto, com o que andava assaz consolado, por lhe parecer que já a fortuna se arrependia de o ter perseguido; porém enganava-se, que quando mais descuidado estava, então de novo o sobressaltou, de modo que mostrava dar a suas perseguições princípio. $^{227}$

Poderíamos mencionar outros exemplos da primeira parte da Constante Florinda, porém é mais proveitoso mostrar que na segunda parte também há um cuidado, explicitado para os leitores, com a brevidade da narração. Em suas incansáveis peregrinações pelo mundo, Arnaldo encontra dois franceses e, levado por eles, vai para a "Grã-Bretanha" e se torna soldado. Por não ser de grande interesse para o enredo esse período em que Arnaldo foi soldado na "Bretanha", o narrador abrevia os acontecimentos da seguinte forma:

E despois que desembarcaram em a terra habitada dos últimos homens, em poucos dias soube Arnaldo da língua, o que bastava para tratar com eles. E porque sucessos de pouca importância não façam a história prolongada, é de saber que os Franceses foram em Bretanha como

\footnotetext{
${ }^{226}$ Infortúnios trágicos da constante Florinda, capítulo XVI, p.149.

${ }^{227}$ Idem, capítulo XXI, p.176.
} 
Dárdano em Samotrácia, por via dos quais foi Arnaldo admitido à milícia, em a qual aproveitou em pouco tempo, de maneira que foi posto em os ofícios que se costumam dar aos soldados mais valorosos. E porque nele chegou a ter tanto crédito, que de todos era tido por um Aníbal nas guerras, por um Hércules nas forças e por um Júlio César em ter nas batalhas ventura, e que na destreza de cavalo imitava aos naturais de Tessália, foi promovido pelo Rei de Grã-Bretanha a capitão de um dos seus exércitos, o qual ofício exercitou por dous anos, se não com muito gosto seu, a contento de todos os soldados. E deixadas algũas batalhas que deu e vitórias que alcançou, pelas quais merecia que Bretanha lhe desse os prémios com que Itália honrou os Marcos, e suas proezas eram dignas de serem pintadas, como as de Augusto César, não em as andas que o levavam à sepultura, senão em távua de lembrança, para que sempre estivessem vivas em a memória, contaremos um caso que lhe aconteceu em lugar da Bretanha, o qual passou nesta maneira. ${ }^{228}$

Todo o longo período que Arnaldo passou no exército da "Bretanha" é resumido apenas nesse pequeno trecho. $\mathrm{O}$ caso que o narrador anuncia que irá contar é que tem relevância para o enredo, pois o protagonista acaba encontrando uma personagem já mencionada e que esclarece uma história que começou a ser contada por um preso ao caçador, no capítulo VI, e que só será devidamente explicada e encerrada com o relato de Onistalda para Arnaldo, nos capítulos XXXV e XXXVI. Por isso, o narrador é breve na descrição da carreira militar do protagonista, que dá rapidamente lugar aos sucessos de Onistalda, de quem o caçador (Flamiano) já tinha falado para Arnaldo, quando ambos eram cativos dos mouros. ${ }^{229}$ Assim, nota-se que a dinâmica e a riqueza do enredo, com seus reconhecimentos e peripécias, dependem, entre outras coisas, da habilidade do narrador em contar longamente aquilo que interessa à história e abreviar o que não acrescenta muito aos acontecimentos que já foram ou que ainda serão narrados.

Por fim, a terceira principal qualidade da narração, segundo os autores antigos, é a verossimilhança. Em termos poéticos, diz Aristóteles que "verossimilmente muitos

${ }^{228}$ Segunda parte da Constante Florinda, capítulo XXXIV, p.233.

229 "Aqui se alterou o coração de Arnaldo, combatido assim da novidade do caso como da lembrança do que Flamiano lhe contara em a prisão, que lhe tinha causado a Moura, pois aquela era Onistalda de Sevilha, a quem amava o preso, que com os parentes fora a Saragoça a vingar a morte de D. Luís e por respeito de Flamiano fora livre" (Idem, capítulo XXXV, p.235). 
casos se dão e ainda que contrários à verossimilhança" (Poética, XVIII, 1456a, 23-24) e "de preferir às coisas possíveis mas incríveis, são as impossíveis mas críveis" (Idem, XXIV, 1460a, 26-27). Nesse sentido, podemos mencionar o seguinte trecho de Los trabajos de Persiles y Sigismunda, que, além da verossimilhança, faz referência ainda à auctoritas que deve ter o narrador: ${ }^{230}$

Cosas y casos suceden en el mundo que, si la imaginación, antes de suceder, pudiera hacer que así sucedieran, no acertara a trazarlos y, así, muchos, por la raridad con que acontecen, pasan plaza de apócrifos y no son tenidos tan verdaderos como lo son. Y, así, es menester que les ayuden juramentos o, a lo menos, el buen crédito de quien los cuenta. ${ }^{231}$

Na primeira parte da obra de Rebelo, a incansável peregrinação de Florinda tem fim em Florença, onde sua "fortuna" começa a mudar e a ventura passa a favorecerlhe. O Duque de Florença "a tomou por filha e a constituiu herdeira de todo seu estado, consentindo a Duquesa com muita vontade, porque lhe queria já muito". ${ }^{232}$ Porém, o Duque determinou que a donzela deveria se casar e, para tanto, ordenou que fossem feitas umas "justas" nas quais seria disputada a mão de Florinda. Vários cavaleiros participaram das disputas; no entanto, o mais misterioso deles, o "Cavaleiro Só", é que acabou vencendo todos os outros com certa facilidade. No momento em que o desconhecido cavaleiro se revela para receber seu prêmio (a mão da donzela), dá-se o acontecimento mais esperado e mais "raro" da história: o reencontro de Florinda e Arnaldo. Tal é a impossibilidade desse reencontro (depois de tantos anos, ${ }^{233}$ viagens e infortúnios) que, para torná-lo crível, o "reconhecimento" só ocorre após a donzela, que sempre trazia consigo um retrato de seu amado, cotejar essa imagem com a "figura" daquele cavaleiro que se lhe apresentava diante dos olhos:

Foi pois o caso que tendo já descoberto seu rostro o Cavaleiro Só, deixado o espanto que a todos pôs sua gentileza, se lançou aos braços do Duque, dos quais foi recebido com muito amor. E despedido deles

\footnotetext{
${ }^{230}$ Lembremo-nos do que afirma Quintiliano em relação à auctoritas: "Ne illud quidem praeteribo, quantam adferat fidem expositioni narrantis auctoritas, quam mereri debemus ante omnia quidem uita, sed et ipso genere orationis; quod quo fuerit grauius ac sanctius, hoc plus habeat necesse est in adfirmando ponderis" (Inst. Orat., IV, II, 125).

${ }^{231}$ Los trabajos de Persiles y Sigismunda, op.cit., p.583.

${ }^{232}$ Infortúnios trágicos da constante Florinda, capítulo XXXVI, pp.281-282.

${ }^{233}$ Arnaldo diz que buscou Florinda por 8 anos (Idem, capítulo último, p.304).
} 
pera tomar a mão à fermosa Florinda, teve lugar antes que chegasse de pôr os olhos nele; e sobressaltando-se-lhe o coração com sua vista, lançando a mão ao seio, tirou o retrato que sempre consigo trazia, e cotejando a imagem dele com o original do cavaleiro, conheceu que era seu amado e querido Arnaldo, a quem ela sempre tivera por morto. ${ }^{234}$

Assim, esse reconhecimento se faz verossímil por meio de um recurso narrativo bastante comum nas epopéias, desde a famosa cena em que a cicatriz de Odisseu serve como marca para que sua velha ama, Euricléia, o reconheça. ${ }^{235} \mathrm{Na}$ primeira parte da Constante Florinda, o reencontro dos amantes é crível, embora pareça impossível, porque a narração recorre a seus modelos poéticos para mostrar aos leitores que o caso que se relata sucede não conforme à verdade da natureza, mas de acordo com a verossimilhança da poesia.

Além disso, vimos que tanto os tratados retóricos como os poéticos afirmam que a verossimilhança também decorre da capacidade do orador ou do poeta de "pôr diante dos olhos" as coisas relatadas. Preceito esse que repercute nos procedimentos da persona que narra a Constante Florinda. No primeiro dia das "justas" em Florença, que culminarão com o reencontro dos amantes, como acima dissemos, quando Florinda surge ante o público, o narrador faz uma descrição extremamente meticulosa de sua bela "figura", dando aos leitores um deleite aos olhos através de um verdadeiro "retrato",236 da donzela:

Florinda saiu neste primeiro dia com um vestido tão rico e de tanto feitio, que mostrava um claro desengano aos olhos de todos, que não havia mais que ver. Era pois este de fio de ouro e prata, sem parecer seda alguma, e com tanto artifício tecidos entre si, que não davam lugar a que se mostrasse a que debaixo tinham. $O$ feitio tinha mais de custo que de artifício, porque a certos compassos tinha seus miúdos golpes, tomados os remates com grãos de aljôfar e no meio servia de botão a cada um sua pedra de muita estima, cada uma de sua cor, presa em um

\footnotetext{
${ }^{234}$ Idem, ibidem, pp.302-303.

${ }^{235}$ Odisséia, XIX, vv.386-468.

236 Sobre o "retrato", imitação primeira do poeta, e não segunda, como a do pintor, recordemos as palavras de Hugo, um dos personagens da Philosophía antigua poética de Pinciano: "porque el autor que remenda a la naturaleza es como retratador y el que remenda al que remendó a la naturaleza, es simple pintor. Así que el poema que inmediatamente remeda a la naturaleza y arte, es como retrato, y el que remedó al retrato, es como simple pintor. Y de aquí veréis de cuánto más primor es la invención del poeta y primera imitación que no la segunda" (Philosophía Antigua Poética, epístola tercera, op.cit., p.111).
} 
sutil alamarzinho de ouro. Em sua cabeça não levava cousa que a cobrisse, mais que seus fermosos cabelos, que pareciam madeixas de fino ouro, sameados de pérolas e apertados com uma fita de prata, engastados nela muitos rubis, e no meio um diamante, que lançava de si muita claridade; em seu pescoço, que parecia de fino cristal, trazia um mantéu aberto com largas pontas de ouro e prata, brincadas de esmeraldas e grãos de aljôfar. Em o meio do peito uma pedra de muita estima, engastada no remate de um grosso colar de ouro, que de seu pescoço pendia. $^{237}$

Nesse trecho, o narrador retrata a beleza de Florinda para deleitar seus leitores. Na segunda parte da obra, no episódio já mencionado do "triste queixoso" (Laureano), a relação entre a pintura e as "histórias antigas" é mencionada de forma mais direta. O narrador não só descreve cuidadosamente a cena, para torná-la um “quadro" verossímil, mas explica também a função que as pinturas têm de mover e ensinar. Isso ocorre no momento em que Laureano leva Arnaldo para ver as "pinturas exemplares" que enfeitam uma pequena sala das "casas" habitadas pelo "triste queixoso".

Assim como as histórias antigas criam inveja em um peito animoso que o está incitando a grandes obras, assim as pinturas exemplares criam em o coração um desejo que o está movendo a buscar as virtudes. E este parece que foi o intento de quem tinha feito aquelas casas tão curiosas ornadas de várias pinturas, entre as quais estava ũa piquena sala mais aventejada, que era esta que Laureano dezia, cujas pinturas eram desta maneira:

Primeiramente em o tecto estava uma figura de mulher entre ũas tarjas e folhagens mui bem lavradas, a qual tinha por título VIRTUDE. O rosto era arrugado, como de mulher já velha, e na fronte tinha esta letra: A virtude há-de ser antiga. Tinha asas, e em elas umas letras que diziam: Corre a parelhas com a Fama, a Virtude perfeita. Estava encostada a uma columna, à vista do espantoso Hércules, que a ameaçava com a maça em a mão, e da boca lhe saía esta letra: Não teme nem recea a Virtude bem fundada. Em seus ombros tinha um monstro

${ }^{237}$ Infortúnios trágicos da constante Florinda, capítulo XXXVI, p.285. 
negro e feio, e outro debaixo dos pés, e neles estas palavras: Assim como a Virtude é carga mui pesada para o vício, assim ao vitorioso é mui pesado o gosto desordenado. O rosto estava descoberto, e em roda esta letra: A ninguém se esconde a Virtude, a todos chama e a todos admite. Estava toda cercada de umas letras grossas que, deziam desta maneira: Não é Virtude não poder cometer pecado, senão saber-se abster do vício. ${ }^{238}$

As demais pinturas, seguindo o modelo dessa primeira, versam sobre a "verdade", a "justiça", a "misericórdia", a "paz", a "prudência", o "amor" e a "negligência". Portanto, assim como Arnaldo, ao ver tais figuras, deveria se sentir incitado a buscar virtudes, da mesma forma deveriam agir os leitores ao "ver" o "retrato" que o narrador faz da cena. Enfim, a narração somente consegue mover e ensinar se as coisas forem relatadas verossimilmente, como se as palavras preenchessem as folhas com pinturas exemplares, cuja perfeição, ainda que inatingível, há de ser sempre buscada.

O ofício de "ensinar" (docere) algo aos leitores fica bastante evidente nos finais das epopéias em prosa seiscentistas, em que os narradores, de um modo geral, explicitam que os protagonistas apenas alcançaram a felicidade, superando inumeráveis infortúnios e trabalhos, porque não se deixaram levar pelos vícios e se mantiveram virtuosos e honrados durante suas árduas peregrinações amorosas. E assim é que se encerra a história dos amantes Nise e Pánfilo em El peregrino en su patria: por terem mostrado, em suas andanças, um ethos pleno de virtudes terminam juntos e felizes:

Pidió Lisardo a Tiberia, que con aplauso de todos le fue concedida, y porque Leandro se consolase del amor de Nise, le dieron a Elisa, bellísima doncella, que apenas cumplía entonces catorce años. Celio casó con Finea, y Nise, tras tantas fortunas, vino a los brazos de Pánfilo, tan merecidos por los innumerables trabajos que pasaron, a cuyas fiestas se hicieron las que se siguen. ¡Dichosos peregrinos de amor, que ya en su patria descansam, cumplido el voto! Y así, pues ellos cuelgan en el templo de la Fortuna sus bordones, yo la pluma en el de la Fama con que he escrito sus desdichas. ${ }^{239}$

\footnotetext{
${ }^{238}$ Segunda parte da Constante Florinda, capítulo XXXII, p.224.

${ }^{239}$ El peregrino en su patria, op.cit., pp.480-481.
} 
Da mesma forma acaba a peregrinação dos amantes de Los trabajos de Persiles y Sigismunda. Durante toda a história, eles se mantiveram firmes e constantes, não sendo tomados pela "paixão", e cumpriram o voto de Sigismunda, que havia prometido "venir a Roma a enterarse en ella de la fe católica"; ${ }^{240}$ por isso, seus trabalhos têm um final ditoso, afirmando o narrador que Persiles e Sigismunda tiveram, após tantos sofrimentos, uma vida longa e repleta de felicidade:

Persiles depositó a su hermano em San Pablo, recogió a todos sus criados, volvió a visitar los templos de Roma, acarició a Constanza, a quien Sigismunda dio la cruz de diamantes y la acompañó hasta dejarla casada con el conde su cuñado y, habiendo besado los pies al Pontífice, sosegó su espíritu y cumplió su voto, y vivió en compañía de su esposo Persiles hasta que bisnietos le alargaron los días, pues los vio en su larga y feliz posteridad. ${ }^{241}$

No fim da primeira parte da Constante Florinda, torna-se ainda mais manifesto o exemplum da história. Depois do reencontro dos amantes em Florença, eles se casaram (com festas que duraram oito dias) "e assim viveram três anos com muita alegria e contentamento, no cabo dos quais (ordenando-o o Céu) morreu o Duque, e daí a um ano a Duquesa, e eles ficaram possuindo todo o seu estado, como senhores verdadeiros, em o qual viveram muitos anos, e despois ficou a seus filhos, como legítimos sucessores deles". ${ }^{242}$ Com base nesse desenlace, o narrador ensina aos leitores que a constância de Florinda em manter a palavra dada a Arnaldo, mesmo diante dos maiores infortúnios, teve como prêmio o reencontro com o amado e um casamento feliz. Dessa maneira, numa perspectiva estóico-cristã, quem for firme e constante, como a heroína, frente aos trabalhos que a vida apresenta, alcançará, após o Juízo Final, a bemaventurança:

E esta é a história da firme e constante Florinda, e de seus trágicos infortúnios, os quais não foram bastantes para que lhe fizessem quebrar a palavra e fé que a seu querido Arnaldo dera, antes permanecendo

\footnotetext{
${ }^{240}$ Los trabajos de Persiles y Sigismunda, op.cit., p.703.

${ }^{241}$ Idem, pp.713-714.

${ }^{242}$ Infortúnios trágicos da constante Florinda, capítulo último, p.307.
} 
firme e constante veio no fim alcançar o doce fruito deles, acompanhado de tantos bens e alevantada com tanta honra como havemos dito. Donde se pode tirar exemplo que, assim como nossa Florinda, por ser constante e firme em sua palavra e fé, e pela guardar passou tantos trabalhos e infortúnios, no fim dos quais alcançou tão grandes bens desta vida; assim também o que permanecer firme e certo em guardar o que prometeu a Deus e passar trabalhos por satisfazer com a obrigação de sua promessa; esteja certo alcançará os bens da outra, que são a bem-aventurança, na qual permita ele nos vejamos todos pera sempre. Amém. ${ }^{243}$

Já a segunda parte da obra tem um final bem mais desolador, com a morte dos dois amantes justamente em decorrência da constância e firmeza de Florinda que, em sua peregrinação, para manter sua palavra dada a Arnaldo, não aceitou os amores de um príncipe, chamado Aquilante. Este, tornando-se Rei de Nápoles, ataca por vingança Florença, onde viviam muito felizes como Duque e Duquesa aqueles amantes, condenaos à morte e desterra o herdeiro. Arnaldo é degolado publicamente e Florinda, vendo-o morto, não suporta a dor e morre logo em seguida. Porém, por mais desoladoras que sejam, tais mortes também parecem querer ensinar algo, como se pode notar nas últimas palavras do narrador:

E este é o fim que tiveram estes dous amantes tão firmes. Estes foram seus trágicos infortúnios. Nisto vieram a parar tantos dons da natureza. Este foi o prémio que teve o desordenado amor da mocidade. E se eles foram firmes às glórias da vida, não tiveram firmeza. Esta verdade nos está ensinando, que tragamos sempre em a memória escritas estas palavras:

Para que são glórias, nem honras da vida, se mais perde quem mais alcança. ${ }^{244}$

Desse modo, o fim trágico dos amantes, mortos por viverem sob os auspícios de um amor desordenado, comprova que almejar os bens desta vida é distanciar-se do único e verdadeiro Bem: aquele que só poderá ser desfrutado depois da morte.

\footnotetext{
${ }^{243}$ Idem, ibidem, p.307.

${ }^{244}$ Segunda parte da Constante Florinda, capítulo último, p.269.
} 
As análises que fizemos da persona que narra a Constante Florinda permitemnos concluir que seu ofício é diferente daquele do orador ou do poeta, embora a ars narrandi seja constituída por preceitos retóricos e poéticos. O narrador configura-se num texto que finge que as coisas são verossímeis, e seu ofício é narrá-las como se assim fossem. Nas technai retórica e poética, ensina-se o que é a narração e como o orador e o poeta devem narrar; no texto da Constante Florinda, o narrador é uma persona que demonstra conhecer aquelas technai, explicitando para o leitor que a direção narrativa é arbitrária, mas que a fábula deve resultar verossímil, para que possa mover deleitando e ensinando. Movidos pelo deleite e pelo ensinamento, os leitores devem agir como os exempla da história narrada. Porém, o próprio narrador tem que mostrar um ethos exemplar; e faz isso através de um discurso ético-patético, com uma prosa sentenciosa e ornamentada que evidencia a auctoritas de uma persona que sabe conciliar muito bem o proveito e o deleite, arranjados harmoniosamente para mover os afetos.

Além disso, a narração de uma epopéia em prosa seiscentista é também determinada pela imitação de seus modelos. Portanto, é preciso levar em consideração que a emulação, segundo Aristóteles,

consiste num certo mal-estar ocasionado pela presença manifesta de bens honoríficos e que se podem obter em disputa com quem é nosso igual por natureza, não porque tais bens pertençam a outrem, mas porque também não nos pertencem (...) é forçoso admitir, então, que émulos são aqueles que se julgam dignos de bens que não têm mas que lhes seria possível vir a conseguir, uma vez que ninguém ambiciona aquilo que lhe é manifestamente impossível" (Retórica, II, 11, 1388a $1388 b)$.

Como consequiência dessa "disputa" provocada pela emulação, podemos recordar o que diz Quintiliano sobre a imitatio:

Ante omnia igitur imitatio per se ipsa non sufficit, vel quia pigri est ingenii contentum esse iis quae sint ab aliis inventa. Quid enim futurum erat temporibus illis, quae sine exemplo fuerunt, si homines nihil, nisi 
quod jam cognovissent, faciendum sibi aut cogitandum putassent? Nempe nihil fuisse inventum (Inst. Orat., X, II, 4).

Se a narração pauta-se pela imitação, ao se narrar, uma cópia servil não é o suficiente. Conforme o trecho citado de Quintiliano, a imitatio depende de um "passo a mais", de uma superação de modelos, pois, do contrário, nada de novo seria inventado e nós jamais sairíamos do mesmo lugar, estando eternamente presos ao nosso passado. $\mathrm{Na}$ narração da Constante Florinda, são imitados os melhores modelos, como as epopéias em prosa antigas de Heliodoro e Aquiles Tácio. Assim, a persona que narra os infortúnios de Florinda e Arnaldo (e os episódios que os envolvem) é imitação de narradores antigos e modernos, que não se confundem com os autores, oradores ou poetas.

A peculiaridade do narrador da Constante Florinda é o próprio texto que ele narra e que, ao mesmo tempo, o constitui. Nessa epopéia em prosa narrada com o emprego de técnicas retóricas e poéticas, o narrador é aquele que conduz a narração: persona única e exemplar, ele é imitação que finge que as res fictae são verdadeiras porque narradas verossimilmente. Ele narra a história, enfim, para que os exempla da fábula movam virtudes. 


\section{Capítulo 3}

\section{Filosofia estóica nos séculos XVI e XVII: uma doutrina estóico-cristã}

No fim do século XVI, é grande a discussão acerca dos ofícios do discurso, em particular, sobre as relações entre o delectare e o docere. É o que mostra, por exemplo, Guido Morpurgo Tagliabue em seu texto Aristotelismo e Barocco. Para o autor, desde o século XV, a Retórica foi sendo reduzida à elocutio, ao ornato, ao deleite, excluindo-se da techne rhetorike a inventio e, conseqüentemente, o ensinamento. Essa tendência de restringir a "arte" ao ornato teria levado, no século XVI, a uma crisi del Rinascimento, que caberia ao século XVII (para o autor, o "Barroco") tentar resolver, conciliando o delectare e o docere:

Il Barocco non è una riduzione dell'oratoria e della poesia e dell' arte al semplice e al superficiale. Anche gli aspetti più frivoli e lucenti del barocco non sono mai semplici. Ciò che appare futile e parziale, del Barocco, tende a recuperare la propria integralità mercè una dialettica interna, che lo fa complesso e sofistico. Quella intrinseca dialletica era imposta dalla problematica della cultura di fine secolo, che abbiamo conosciuta. Della antinomie, alle quali il tardo Rinascimento era pervenuto in ogni campo. E qualcuna ne abbiamo veduta: l'antinomia tra il trionfo e la condanna della retorica, e cioè tra una concezione autonoma e una eteronoma della oratoria; e l'antinomia tra una estrema elaborazione stilistica dell'arte figurativa e l'istanza che essa suscitava, presso i manieristi, di un rinnovato appello all'universale, all'idea; infine l'antinomia tra una concezione hedonística e una concezione pedagogica della letteratura. Tutti aspetti che possiamo esprimere con l'antitesi tra il delectare e il prodesse, portata a maturazione dal clima della controriforma; e la cui origine è da cercare in quel declino dell'inventio, in quella crisi degli endoxa, di cui abbiamo parlado. Gli «endoxa» sfuggono all'inventio, e non sono più per il letterato un patrimonio convenuto, ma un compito, una scelta, un problema, talvolta una questione di conformismo o di eterodossia o di libertinismo. Questa 
la natura della crisi che porta un dislocarsi dell'espressione oratoria e poetica. ${ }^{245}$

Nesse mesmo sentido, mas com outros termos, João Adolfo Hansen destaca o lugar central do "prazer do ornamento" na poesia seiscentista:

Este funcionamento retórico da poesia antiga (...) muda quanto à clareza e à congruência em fins do século XVI e no século XVII, na poesia que hoje se conhece por "barroca": o prazer do ornamento tornase então central, o episódico passa a ser proposto como fundamental, a incongruência e a obscuridade se fazem programáticas. Em outros termos, a elocução e seus ornamentos passam a preencher os lugares tradicionais da invenção poética: a poesia passa a ser produzida como desenvolvimento ornamental de ornamentos de base. Tornado "elocução engenhosa" ou "ornato dialético", na base do procedimento encontra-se o conceito, termo de grande polissemia e várias aplicações, muitas vezes equivalentes a agudeza, argúcia, entimema, silogismo retórico, também nomes do efeito de maravilha. ${ }^{246}$

Porém, quando se trata da prosa seiscentista, e, em particular, da epopéia em prosa, há que se ter cautela ao se referir a uma sobrevalorização do deleite. ${ }^{247}$ Não se pode negar que há um predomínio do delectare; no entanto, seria imprudência desvalorizar o docere e o mouere. Tal prosa, ou melhor, épica em prosa, deleita ensinando, ensina deleitando, e move pelo deleite e pelo ensinamento. Os três ofícios se articulam e se misturam de maneira que só há prazer no ornamento se houver também escarmento e moção. Isolar qualquer um deles é desarticular o gênero e diminuir a sua posição retórico-poética elevada. É o que podemos depreender das palavras de Adma Muhana:

\footnotetext{
${ }^{245}$ Tagliabue, G.M. "Aristotelismo e Barocco". In: Retorica e Barocco. Atti del III Congresso Internazionale di Studi Umanistici. A cura di Enrico Castelli. Roma: Fratelli Bocca, 1955, p.136.

${ }^{246}$ Hansen, J.A. A sátira e o engenho: Gregório de Matos e a Bahia do século XVII. $2^{\mathrm{a}}$ ed. rev. São Paulo: Ateliê Editorial; Campinas: Editora da Unicamp, 2004, p.304.

${ }^{247}$ Como se diz na primeira parte do Don Quijote, tais "escritos" têm a finalidade de "enseñar, y deleitar juntamẽte (...). Porque la escritura desatada de estos libros, da lugar a que el autor pueda mostrarse Epico, Lírico, Tragico, Comico, con todas aquellas partes q̃ encierrã en sí las dulcissimas y agradables ciencias de la Poesía, y de la Oratoria: que la Epica tambien puede escriuirse en prosa, como en verso" ( $E l$ ingenioso hidalgo Don Quixote de la Mancha. Madrid: Juan de la Cuesta, 1605, cap. XLVII, pp.290291).
} 
Embora seja certo que na epopéia e em prosa predomina o delectare (...) ela nunca exclui mouere e docere das suas atribuições porque trata altamente das coisas (...). Somente deleitar não convém a gêneros elevados, mas sim a gêneros medíocres, "pintados e floridos" como o lírico e o pastoril, onde o poeta fabula e razoa como sobre o uso comum (...). Desde que apagada uma sinonímia estreita de iucunditas a deleite, iucunda é a narratio da fábula épica, onde docere e delectare se alternam, como costuma numa narração de estilo médio (...), mas onde a gravidade também exige mouere para se fazer elevada, seja nos episódios patéticos, seja na peripécia com agnósis da ação principal. ${ }^{248}$

Por isso, para se compreender a narração de uma epopéia em prosa é preciso tanto investigar as técnicas empregadas, como fizemos, quanto buscar as fontes dos argumentos usados para mover instruindo. Mas, vale ressaltar, nada disso se dá isoladamente no texto; apenas neste estudo é que tais questões podem ser separadas. Na narração, a técnica já implica o argumento. Enfim, se naquilo que o narrador diz, em particular, ensina-se algo, e assim determina o gênero do texto narrado, tem que haver algo para ser ensinado, algo que, tecnicamente, mova os leitores deleitando-os; e para movê-los, são necessários argumentos adequados. Diante de uma tal necessidade, do decoro da persona que narra ante seus leitores, é que um uso de argumentos estóicos é retórica e poeticamente apropriado. Portanto, para tentar entender melhor o que é dito pelo narrador, a "fonte estóica" nos parece de suma importância, não só para essa narração específica, mas para muito do que nos restou da res literaria ${ }^{249}$ seiscentista.

Sobre a história da filosofia estóica, já se escreveu muita coisa, e foge aos intuitos deste trabalho querer recontá-la minuciosamente ou acrescentar alguma "novidade" ao que já foi feito. Entretanto, não seria pertinente nos furtarmos de fazer um esboço da Stoa, para que as questões que motivaram este estudo fiquem bem localizadas entre as discussões que as precederam.

\footnotetext{
${ }^{248}$ Muhana, A. A epopéia em prosa seiscentista, op.cit., p.250.

${ }^{249}$ Ao utilizarmos esse termo, remetemo-nos às discussões de Marc Fumaroli sobre as noções de "Retórica", "Res Literaria" e "Literatura", em seu livro L'âge de l'éloquence: rhétorique et "res literaria" de la Renaissance au seuil de l'époque classique. Podemos citar, em especial, os seguintes trechos: "Il s'agit en somme de voir la culture rhétorique du XVII ${ }^{\mathrm{e}}$ siècle non plus à travers un concept de 'littérature' élaboré tardivement, mais à l'aide de ses propes critères, et des débats dont ils étaient l'objet en leur temps" (Paris: Albin Michel, 1996, p.20) ; e "Âge de l'Éloquence, âge de la rhétorique, le XVII siècle voit naître les Belles-Lettres : il n'est pas encore l'âge de la littérature” (Idem, p.31).
} 
Dessa forma, vejamos o que tradicionalmente se entende por "filosofia estóica". ${ }^{250}$ Desde Diógenes Laércio, repetiu-se muitas vezes a suposta origem do termo estóicos:

Zênon costumava dar as suas lições passeando de um lado para outro na Colunata Pintada (Poikile Stoá), também chamada de Colunata de Peisiânax, mas que recebeu o sue nome por causa das pinturas de Polígnotos (o objetivo de Zênon era evitar a presença de profanos). Naquele local foram mortos mil e quatrocentos cidadãos atenienses na época dos Trinta. Lá, então, os cidadãos vinham ouvir Zênon, e por isso passaram a ser chamados estóicos; assim também foram chamados seus seguidores, que a princípio tinham o nome de zenonianos, como afirma Epícuros nas Epístolas. De acordo com Eratostenes no oitavo livro de sua obra Sobre a Comédia Antiga, a designação de estóicos tinha sido aplicada anteriormente aos poetas que passavam o tempo naquele local, tornando ainda mais famoso o nome. ${ }^{251}$

A partir da doutrina desses primeiros estóicos e, particularmente, da exposição que fez dela Diógenes Laércio, é que se passou a se falar de uma filosofia estóica. Assim, com base no livro VII das Vidas de Diógenes Laércio, tentaremos resumir alguns dos pensamentos desses primeiros filósofos, que deram origem à escola estóica e que determinaram a sua doutrina.

Os estóicos dividiram a filosofia em 3 partes: lógica, ética e física. Nenhuma dessas partes pode ser separada da outra, pois estão unidas estreitamente entre si. Na repisada comparação da filosofia com um ovo, a casca seria a lógica, a clara a ética, e a

\footnotetext{
${ }^{250}$ Nesse brevíssimo esboço, baseamo-nos, especialmente, nos seguintes textos: no livro VII das Vidas e Doutrinas dos Filósofos Ilustres, de Diógenes Laércio (Tradução do grego, introdução e notas Mário da Gama Kury. $2^{\mathrm{a}}$ ed. Brasília: UnB, 1977); nos estudos clássicos de Max Pohlenz, Die Stoa: Geschichte einer geistigen Bewegung (Göttingen : Vandenhoeck \& Ruprecht, 1948-49), e de Émile Bréhier, Chrysippe et l'ancien stö̈cisme (Paris; New York : Gordon \& Breach, 1971); nos textos introdutórios de F.H. Sandbach, The Stoics (Bristol: Bristol Press, 1989), de Paul Veyne, Séneca y el estoicismo (Trad. de Monica Utrilla. México, D.F. : Fondo de Cultura Económica, 1995), de Frédérique Ildefonse, Les Stö̈ciens (Paris: Les Belles lettres, 2000), de Jean Brun, Le Stoïcisme (Paris: PUF, 2003), e de Robert Muller, Les stoïciens: la liberté et l'ordre du monde (Paris : J. Vrin, 2006); além do The Cambridge companion to the Stoics (edited by Brad Inwood. Cambridge, U.K.; New York : Cambridge University Press, 2003), que foi traduzido para o português com o título de Os Estóicos (Trad. Paulo Fernando Tadeu Ferreira e Raul Fiker. São Paulo: Odysseus, 2006).

${ }^{251}$ Vidas e Doutrinas dos Filósofos Ilustres, VII, 5.
} 
gema a física; cada uma com sua função, mas formando um composto único e articulado. $^{252}$

$\mathrm{Na}$ lógica estóica, ${ }^{253}$ merecem destaque as noções de phantasia e de conhecimento. ${ }^{254}$ A phantasia é uma impressão na psyché, "e tirou-se o seu nome adequadamente da marca feita por um sinete na cera". ${ }^{255}$ Já o conhecimento é "uma percepção segura, ou uma faculdade de receber a apresentação (phantasia), que não pode ser abalada pela razão". ${ }^{256}$ E o critério da verdade seria justamente a phantasia, "que apreende imediatamente a realidade, ou seja, que procede do existente". ${ }^{257} \mathrm{Com}$ base nessas noções, esses primeiros estóicos também refletiram sobre a linguagem e, em especial, sobre os lekta. ${ }^{258}$ Em suma, a phantasia constituiria o esquema sensível inicial, que o lekton deveria desenvolver discursivamente. ${ }^{259}$

Não é por causa de suas contribuições à lógica que os estóicos ficaram conhecidos posteriormente. Embora as três partes da filosofia devessem compor um conjunto, a doutrina estóica foi sendo reduzida à ética (como veremos, principalmente nos séculos XVI e XVII). A figura do sábio estóico, imperturbável ante as paixões, impassível frente às desgraças, é a primeira imagem que surge em grande parte dos textos que mencionam a doutrina da Stoa. Devido a uma tal relevância dos frutos do "campo fértil" 260 da filosofia, seria absurdo querer esgotar as muitas questões que a ética estóica suscitou. Neste momento, mencionaremos apenas aquilo que consideramos básico ou mínimo para um esboço inicial, tendo ainda como nossa principal fonte Diógenes Laércio. ${ }^{261}$ Ao longo do nosso estudo, muitas outras idéias éticas ou morais dos estóicos serão trabalhadas.

\footnotetext{
${ }^{252}$ Idem, VII, 40.

${ }^{253}$ Escapa aos intuitos deste trabalho abordar detalhadamente os diversos aspectos da lógica dos estóicos. Para uma visão mais completa do tema, recomendamos os textos de Les Stoïciens et Leur Logique. Sous la direction de Jacques Brunschwig. Paris: J. Vrin, 2006.

${ }^{254}$ Ver, por exemplo, as considerações de Frédérique Ildefonse, em Les Stoïciens, op. cit., pp.71-142.

${ }^{255}$ Vidas e Doutrinas dos Filósofos Ilustres, VII, 45.

${ }^{256}$ Idem, VII, 47.

${ }^{257}$ Idem, VII, 54.

${ }^{258}$ Idem, VII, 55-82. Para uma análise cuidadosa sobre o conceito do lekton estóico, vejam-se os textos "The Stoic notion of lekton", de Michael Frede (In: Companions to ancient thought 3. Language. Edited by Stephen Everson. Cambridge; New York : Cambridge University Press, 1994, pp.109-128), e "Contribuição estóica à gramática tradicional", de David Blank e Catherine Atherton (In: Os Estóicos, op.cit., pp.343-362).

${ }^{259}$ Cf. Ildefonse, F., Les Stoïciens, op.cit., p.139.

${ }^{260}$ Lembre-se que Diógenes Laércio também relata que os estóicos comparavam a filosofia a um campo fértil, no qual a cerca externa seria a lógica, os frutos a ética, e o solo ou as árvores, a física (Vidas e Doutrinas dos Filósofos Ilustres, VII, 40).

${ }^{261}$ Vale ressaltar que uma outra excelente fonte antiga sobre a moral estóica é o livro III do De finibus de Cícero.
} 
Quanto à ética, ${ }^{262}$ os filósofos da Stoa dividiram-na em doutrinas do impulso, do bem e do mal, das paixões, da excelência, do fim supremo, do valor mais alto, dos deveres e da exortação e dissuasão em face da ação. ${ }^{263} \mathrm{O}$ primeiro impulso (hormé) do homem seria o da sobrevivência, e não em direção ao prazer, como afirmavam os epicuristas. Nos animais, à diferença das plantas, há um impulso que os fazem seguir seus próprios fins. Portanto, “já que os seres racionais receberam a razão com vistas a uma conduta mais perfeita, sua vida segundo a razão coincide exatamente com a existência segundo a natureza, enquanto a razão se agrega a eles como aperfeiçoadora do impulso". ${ }^{264}$ Eis, em linhas gerais, um dos conceitos estóicos que mais suscitará discussões: o secundum naturam uiuere. ${ }^{265}$

Outro fundamental conceito para a doutrina estóica, a virtude ou excelência (areté), teria sido definida por Crisipo como uma disposição da psyché "harmoniosamente equilibrada, digna de ser escolhida em si e por si, e não por qualquer temor, ou esperança, ou impulso exterior". E a felicidade consiste justamente na virtude, pois esta é "como uma alma que tende a tornar toda a vida harmoniosa". ${ }^{266}$ As quatro virtudes primárias ou principais são: prudência (phronesis), coragem (andreia), justiça (dikaiosyne) e temperança (sophrosyne). Logo, os vícios primários são: imprudência, covardia, injustiça e intemperança; e o vício (kakia) é definido como "a ignorância das coisas cujo conhecimento constitui a excelência". ${ }^{267}$

Das virtudes, Diógenes Laércio passa a tratar do bem. Segundo ele, para os estóicos, o bem é o útil ou, ainda, a "perfeição natural de um ser racional enquanto racional". ${ }^{268} \mathrm{E}$ o bem perfeito é o belo, "porque está repleto de todos os fatores requeridos pela natureza, ou porque tem proporções perfeitas". ${ }^{269}$ Todos os bens são iguais e nenhum pode ser aumentado ou diminuído. Das coisas que existem, algumas são boas e outras são más, e outras não são nem boas nem más. Estas últimas são "indiferentes" (adiaphora), pois não contribuem nem para a felicidade nem para a

\footnotetext{
${ }^{262}$ Para uma introdução sucinta à ética da filosofia da Stoa, veja-se o texto de Malcon Schofield: "Ética estóica" (In: Os Estóicos, op.cit., pp.259-284).

${ }^{263}$ Vidas e Doutrinas dos Filósofos Ilustres, VII, 84.

${ }^{264}$ Idem, VII, 86.

${ }^{265}$ Sêneca, por exemplo, afirma que viver feliz é viver segundo a natureza: "Idem est ergo beate uiuere et secundum naturam" (De Vita Beata, VIII, 2).

${ }^{266}$ Doutrinas dos Filósofos Ilustres, VII, 89.

${ }^{267}$ Idem, VII, 93.

${ }^{268}$ Idem, VII, 94.

${ }^{269}$ Idem, VII, 100.
} 
infelicidade, assim como não provocam nem atração nem aversão. ${ }^{270}$ Mas mesmo entre as indiferentes, algumas coisas merecem ser escolhidas e outras rejeitadas, dependendo de seu "valor". 271

Sobre o dever (kathekon), destacaremos, neste momento, apenas a sua definição: "o ato passível de ser justificado racionalmente, desde que seja conforme à natureza na vida, que se estende até as plantas e os animais". ${ }^{272}$ Vale lembrar, no entanto, a importância que as idéias estóicas sobre os deveres adquirirão ao serem difundidas (ainda que muitas vezes questionadas) pelo De Officiis de Cícero, que teve como principal modelo um perdido tratado de Panécio: Peri Kathekontos. ${ }^{273}$

Por fim, no que diz respeito à ética, não poderíamos deixar de mencionar a doutrina estóica das "paixões" (pathé), ${ }^{274}$ uma questão que, em última instância, passou a ser confundida com a própria filosofia estóica. O pathos, segundo Zenon, é um movimento da psyché, "irracional e contrário à natureza, ou um impulso excessivo". 275 As principais paixões, das quais derivam as outras, são a dor, o medo, a concupiscência e o prazer. E tais pathé são enfermidades ou doenças da psyché, como aquelas que atingem o corpo. ${ }^{276}$ Entretanto, algumas “disposições passionais” são boas - a alegria, a cautela e a vontade - e opõem-se àquelas paixões doentias.

O sábio estóico é aquele que está "imune às paixões porque não pode cair diante delas", ou seja, nele quem domina é a apatheia. É curioso notar que tal palavra, que causará tanta discussão (e será tão criticada), como veremos, entre os autores que tentaram coadunar a doutrina estóica com a cristã, já carrega consigo, desde Diógenes Laércio, também um sentido negativo: “o termo 'apatia', que designa propriamente a ausência de paixões, pode aplicar-se também ao homem mau, no sentido de que ele é

\footnotetext{
${ }^{270}$ Com relação à teoria dos "indiferentes" (adiaphora) no estoicismo antigo, v. Stoicorum Veterum Fragmenta (SVF), I, 191 e ss.; II, 177 e ss.

271 'Eles entendem por 'valor' uma certa contribuição à vida equilibrada pela razão, requisito de todo bem; mas, entendem também uma certa potência ou utilidade mediata que contribui para a vida segundo a natureza, como a contribuição que a saúde e a riqueza trazem à vida segundo a natureza" (Doutrinas dos Filósofos Ilustres, VII, 105).

${ }^{272}$ Idem, VII, 107.

${ }^{273}$ Ver a respeito o "Prefácio" de Pierre-Maxime Schuhl: Les Stoïciens. Textes traduits par Émile Bréhier. Paris : Gallimard, 1997, p.xxxix.

${ }^{274}$ Além de Diógenes Laércio, talvez a principal fonte antiga para se compreender o pathos estóico sejam as Tusculanae Disputationes de Cícero, em especial, os livros III e IV.

${ }^{275}$ Vidas e Doutrinas dos Filósofos Ilustres, VII, 110.

276 "A enfermidade da alma é uma afecção ligada à debilidade, e consiste em imaginar que uma coisa é fortemente desejável, quando na realidade não é" (Idem, VII, 115). Ver também as Tusculanae Disputationes, III, IV-V, 8-10; particularmente, o seguinte trecho: "Ita fit ut sapientia sanitas sit animi, insipientia autem quasi insanitas quaedam, quae est insania eademque dementia" (III, V, 10).
} 
insensível e não se deixa comover". ${ }^{277}$ Outra questão bastante delicada para os estóicocristãos será aquela dos sábios considerados como deuses (para os cristãos, rivais de Deus): "Os sábios são criaturas divinas, pois têm em si, por assim dizer, a divindade". ${ }^{278}$ Para a Stoa antiga, somente o sábio é livre e capacitado para governar, julgar e discursar, enquanto o néscio ou estulto é sempre servo. Por isso, a amizade só existe entre sábios, pois apenas eles são homens bons. Assim como todos os bens são iguais e não podem ser divididos, todas as virtudes também o são, e quem possuir uma, possuirá todas. Não há meio termo, como queriam os peripatéticos: ou se é virtuoso ou se é vicioso. $^{279}$

Para encerrar essas considerações sumárias sobre a ética, vale a pena citar o trecho em que se afirma que o suicídio é aceitável em casos extremos, outro grande problema que dificultará a conjugação da filosofia estóica com a cristã: "Os estóicos afirmam que o sábio desprezará a vida se tiver motivos razoáveis, como por exemplo a salvação da pátria ou dos amigos, ou se for atormentado por dores insuportáveis, mutilação ou doenças incuráveis". 280

Resta tratar da terceira parte da filosofia: a física. Faremos uma análise muito mais sucinta do que a feita em relação à ética, pois são as questões morais que predominam nos textos quinhentistas e seiscentistas. Como vimos, os estóicos antigos concebiam a filosofia como um todo, como um corpo, e isolar a ética, ou qualquer outro membro, seria aleijar a doutrina. Porém, tal aleijamento sempre existiu, desde os autores antigos, e ainda mais nos quinhentistas e seiscentistas. Portanto, se não acompanharmos essa tendência mutiladora, nosso estudo é que ficará "aleijado".

Pois bem. Quanto à física, ${ }^{281}$ destacaremos quatro temas: Deus, natureza (physis), destino (heimarmene) e psyché (que, posteriormente, será entendida e discutida pelos autores cristãos como "alma”). Para a Stoa antiga, Deus é uma substância única, mas que pode ser chamada por diferentes nomes, como mente, destino ou Zeus. Enfim, ele criou tudo, está em toda parte e governa todas as coisas:

\footnotetext{
277 Vidas e Doutrinas dos Filósofos Ilustres, VII, 117.

${ }^{278}$ Idem, VII, 119.

${ }^{279}$ Idem, VII, 127.

${ }^{280}$ Idem, VII, 130.

${ }^{281}$ Para uma abordagem inicial, ver o texto de Michael J. White: "Filosofia natural estóica (Física e Cosmologia)" (In: Os Estóicos, op.cit., pp.139-170). Um estudo detalhado dos conceitos de determinismo e de liberdade na doutrina estóica, especialmente em Crisipo, foi feito por Susanne Bobzein, em Determinism and freedom in stoic philosophy (Oxford: Clarendon Press, 2005).
} 
Deus é um ser imortal, racional, perfeito e inteligente, feliz, insusceptível de qualquer mal, solícito em sua providência, em relação ao cosmos e a tudo que está no mesmo, mas não tem forma humana. É o demiurgo do universo e, como se fosse o pai de todas as coisas, é aquilo que penetra em toda parte, total ou parcialmente, e recebe muitos nomes de acordo com as várias modalidades de sua potência. ${ }^{282}$

Já a natureza é uma capacidade que se move por si mesma e que, de acordo com os princípios seminais, "produz e conserva tudo que germina por si em períodos definidos, fazendo as coisas como elas são e obtendo resultados condizentes com suas fontes" e visando sempre à utilidade e ao prazer. ${ }^{283}$ Se Deus criou e a natureza produz e conserva, o destino ${ }^{284}$ faz com que as coisas aconteçam como deveriam acontecer, pois "é um encadeamento de causas daquilo que existe, ou a razão que dirige e governa o cosmos". 285

Finalmente, outro tema que repercutirá bastante nos séculos XVI e XVII é a definição estóica de psyché, numa posterior interpretação cristã, a "alma". Para os estóicos antigos, a natureza é um fogo artífice, um sopro (pneuma) ígneo criador. "A alma é capacidade de sentir,(...) um sopro congênito conosco; por isso é corpo e permanece depois da morte, sendo entretanto corruptível. A alma universal, ao contrário, é incorruptível, e dela são partes as almas dos animais". ${ }^{286}$ A corporeidade ou incorporeidade, corruptibilidade ou incorruptibilidade da "alma", ocuparão, num diálogo crítico com a doutrina estóica, grandes espaços nos escritos dos cristãos, desde os Padres da Igreja, como, por exemplo, no De anima de Tertuliano.

Como dissemos, nossa intenção era fazer um esboço, o mais simples possível, de como foi transmitida, principalmente por Diógenes Laércio, a história da origem da doutrina estóica e de suas primeiras discussões. Atualmente, nos textos que abordam a filosofia estóica, costuma-se dividi-la em três períodos, com seus respectivos principais representantes. Vale a pena pelo menos mencionar essa divisão, para que tenhamos uma

\footnotetext{
${ }^{282}$ Vidas e Doutrinas dos Filósofos Ilustres, VII , 147.

${ }^{283}$ Idem, VII, 148-149.

${ }^{284}$ As discussões sobre o destino entre os autores antigos, como Cícero no De Fato, já dialogavam com idéias e conceitos provenientes da doutrina estóica. Nos séculos XVI e XVII, em particular, os debates acerca das relações entre Fatum, Fortuna e Providentia serão uma constante, devido em grande medida à necessidade de uma assimilação cristã de conceitos pagãos. O De Prouidentia, de Sêneca, exercerá um papel importante no sentido de fomentar as polêmicas e de sustentar os argumentos.

${ }^{285}$ Vidas e Doutrinas dos Filósofos Ilustres, VII, 149.

${ }^{286}$ Idem, VII, 156.
} 
idéia sobre o que está a se falar quando é citado o "estoicismo". ${ }^{287}$ Na primeira fase, por volta do século IV a.C., iniciou-se a doutrina, como vimos, com os ensinamentos de Zenon na Stoa Poikile; Zenon foi sucedido por Cleantes na direção da escola que, posteriormente, deu lugar a Crisipo, estendendo-se esse primeiro período até fins do século III. Num segundo momento, fala-se de um "Estoicismo Médio" que, nos séculos II e I a.C., foi fruto dos pensamentos de filósofos como Panécio e Posidônio. Por fim, o terceiro período refere-se ao chamado "Estoicismo Romano ou Imperial" que, nos primeiros séculos da nossa era, foi encabeçado por Sêneca, Epicteto e Marco Aurélio.

Muito mais relevante do que essa esquematização pouco profícua é saber que os primeiros preceitos da doutrina estóica só são conhecidos através de fragmentos, citados em textos de autores posteriores que, muitas vezes, os mencionam apenas para criticar os estóicos. De Zenon, por exemplo, restaram 330 fragmentos e nada mais. ${ }^{288}$ Como textos "completos", somente podemos ler aqueles dos filósofos do dito "Estoicismo Romano", aqueles de Sêneca, de Epicteto (que, na verdade, são compilações de seus ensinamentos publicadas por seu discípulo Arriano) e de Marco Aurélio.

Atualmente, a principal compilação dos fragmentos dos primeiros estóicos é a de Arnim: os famosos Stoicorum Veterum Fragmenta. ${ }^{289}$ O compilador facilita, e muito, o trabalho daqueles que desejam ver as "fontes" da filosofia estóica, pois a recolha é toda dividida por filósofos e assuntos, com as devidas referências da proveniência dos fragmentos. Porém, os autores quinhentistas e seiscentistas não tinham acesso a uma tão cuidadosa compilação. Eles tinham que recorrer aos próprios textos que mencionam os fragmentos ou a florilégios e compêndios de sentenças, provérbios ou emblemas pouco confiáveis. Por isso, um trabalho como o de Émile Bhéhier, em Les Stö̈ciens, ${ }^{290}$ que não isola os fragmentos, mas seleciona longos trechos das "fontes", embora dificulte um pouco um conhecimento mais sistemático da doutrina estóica, evidencia melhor como

\footnotetext{
287 Robert Muller problematiza, com acerto, a noção de “estoicismo”. A “filosofia estóica” apenas artificialmente pode ser considerada como um "sistema", pois sua "história" é muito mais aquela de seus filósofos, isoladamente, do que a sistematização de um pensamento em comum ("Introduction: les Stoïciens ou le Stoïcisme?". In: Les stö̈ciens, op.cit., pp.11-16). Por isso mesmo, evitaremos usar o termo "estoicismo" no nosso trabalho e, mais adiante, voltaremos a essa questão e explicaremos melhor os motivos de nossas opções terminológicas.

${ }^{288}$ Cf. Émile Bréhier, Les Stö̈ciens, op.cit., p.3.

289 Arnim, Hans Friedrich August von. Stoicorum veterum fragmenta. 4v. Lipsiae: in aedibus B.G. Teubneri, 1903-24.

${ }^{290}$ Já citado.
} 
ocorreu a difusão dessa filosofia, mostrando bem que, às vezes, ela é divulgada por quem justamente queria calá-la.

Assim sendo, parece pertinente mencionar alguns dos autores antigos mais relevantes para tal divulgação. ${ }^{291}$ Como pudemos notar, Diógenes Laércio, no livro VII das Vidas e Doutrinas dos Filósofos Ilustres, talvez tenha sido a principal auctoritas que organizou e difundiu a doutrina estóica. Cícero (que em muitos de seus escritos filosóficos ${ }^{292}$ refere-se aos ensinamentos estóicos) e Fílon de Alexandria também contribuíram bastante para o posterior conhecimento da filosofia da Stoa. Declarados adversários dos estóicos são também fontes essenciais, como Plutarco, principalmente com as Contradições dos estóicos e Sobre as noções comuns, contra os estóicos, Sexto Empírico e Galeno. Além disso, não podemos esquecer de ressaltar a importância dos Padres da Igreja ${ }^{293}$ nesse trabalho de difusão, que em muitos de seus textos já buscavam conciliar a doutrina estóica com a cristã ou, mais freqüentemente, questionar a primeira em defesa da segunda.

Já dos estóicos do período romano, vários de seus escritos foram preservados e muito lidos em épocas posteriores. De Sêneca, restou o maior número de textos, sendo essa, talvez, uma das causas da sua posição de destaque na filosofia estóica, em especial, para os autores dos séculos XVI e XVII. Uma detalhada história da recepção das obras de Sêneca, desde o século XIII até o XVII, na Espanha e na Europa de um modo geral, foi feita por Karl Alfred Blüher em seu excelente estudo Séneca en España, ${ }^{294}$ ao qual recorreremos diversas vezes ao longo deste trabalho. De Epicteto, conhecemos aquilo que seu discípulo Arriano nos legou: o Encheiridon e as Diatribes. Por fim, de Marco Aurélio, conhecemos as suas Meditações.

Com essa breve exposição, tentamos recapitular aquilo que tradicionalmente é visto como o "estoicismo". Fizemos isso com o objetivo de situar as discussões quinhentistas e seiscentistas sobre a doutrina estóica, as quais, dialogando abertamente

\footnotetext{
${ }^{291}$ Nesse elenco seguiremos os passos de Émile Bréhier.

${ }^{292}$ Para exemplificar, citemos alguns: o livro II dos Academica, o livro III do De Finibus, os livros III e IV das Tusculanae Disputationes, o livro II do De Natura Deorum, todo o tratado De Fato, os 3 primeiros livros do De Officiis e, é claro, os Paradoxa Stoicorum.

293 Sobre o estoicismo nos Padres da Igreja, há um estudo de Michel Spanneut que é todo dedicado ao tema: Le stö̈cisme des pères de l'Église de Clément de Rome à Clément d'Alexandrie. Paris: Seuil, 1957.

${ }^{294}$ Blüher, K. A. Séneca en España: investigaciones sobre la recepción de Séneca en España desde el siglo XIII hasta el siglo XVII. Versión española de Juan Conde. Edición corregida y aumentada. Madrid: Gredos, 1983.
} 
com os preceitos dos autores antigos, tendem quase sempre a delineá-los com um contorno cristão.

A importância da filosofia estóica para o século XVI começou a ser pensada e discutida a partir, principalmente, do trabalho pioneiro de Léontine Zanta: La Renaissance du Stö̈cisme au XVI ${ }^{e}$ siècle. ${ }^{295}$ Posteriores a esse estudo, muitos outros textos sobre o tema foram sendo publicados, ${ }^{296}$ mas pouquíssimos referentes ao "mundo português" (ao fazer tal afirmação, queremos dizer que são muito raros os trabalhos dedicados ao assunto escritos em língua portuguesa ou, ao menos, que tratem de autores portugueses). ${ }^{297}$

Para começar a discutir a questão, é preciso fazer uma ressalva. Em quase todos os estudos sobre o tema, utiliza-se o termo "neo-estoicismo" para nomear essa retomada da Stoa que, para Léontine Zanta, teve início com Petrarca. Pelo que pudemos verificar, eis um dos primeiros usos: "Pétrarque est l'initiateur de ce mouvement qui aboutira à une sorte de stoïcisme christianisé, et que nous pourrons appeler le néostö̈cisme". ${ }^{298}$ Nos textos que lemos, essa expressão é difundida sem qualquer tipo de questionamento, como se fossem óbvios seu significado e sua validade. ${ }^{299}$ Porém, neste

\footnotetext{
${ }^{295}$ Zanta, L. La Renaissance du Stö̈cisme au XVI siècle. Thèse pour le Doctorat ès Lettres, présentée à la Faculté des Lettres de l'Unversité de Paris. Paris: Honoré Champion, 1914.

${ }^{296}$ Citemos, apenas para ilustrar, algumas obras (ao longo do nosso estudo, outros títulos serão mencionados): Saunders, J.L. Justus Lipsius: The Philosophy of Renaissance Stoicism. New York: The Liberal Arts Press, 1955; Spanneut, M. Permanence du stoïcisme de Zenon à Malraux. Bruxelles-Paris: Duculot, 1973; Oestreiche, G. Neostoicism and the Early Modern State. Cambridge: Cambridge University Press, 1982; Morford, M. Stoics and Neostoics. Rubens and the Circle of Lipsius. Princeton: Princeton University Press, 1991; Lagrée, J. Juste Lipse et la Restauration du Stoïcisme. Paris: J. Vrin, 1994; Le stö̈cisme au XVI et au XVII siècle: Le retour des philosophies antiques à l'âge classique. Tome I. Sous la direction de Pierre-François Moreau. Paris: Albin Michel, 1999; Carabin, D. Les idées stö̈ciennes dans la littérature morale des XVI et XVII siècles (1575-1642). Paris: Champion, 2004; e Stoïcisme et Christianisme à la Renaissance, Cahiers V.L. Saulnier 23. Reponsable Catherine Magnien. Paris: Rue d'Ulm/Presses de l'École normale supérieure, 2006.

${ }^{297}$ Podemos citar, por exemplo, quatro textos que tocam, bastante superficialmente, no "estoicismo" de D. Francisco Manuel de Melo: Manupella, G. "Acerca do Cosmopolitismo Intelectual de D. Francisco Manuel de Melo" (In: Brasília, volume XI, Coimbra, 1961, pp.59-76); Carvalho, J. A. de. "A poesia sacra de D. Francisco Manuel de Melo" (In: Arquivos do Centro Cultural Português, volume VIII. Paris: Fundação Calouste Gulbenkian, 1974, pp. 295-404); Spina, S. "Introdução" d' A tuba de Calíope (São Paulo: Brasiliense; Edusp, 1988, pp. 15-21); e Pires, M. L. G. "O tema da «guerra interior» nas Obras Métricas de D. Francisco Manuel de Melo" (In: Xadrez de Palavras: Estudos de Literatura Barroca. Lisboa: Cosmos, 1996, pp.53-74). Além disso, há o "Posfácio" de Adma Muhana, em sua edição dos Infortúnios trágicos da constante Florinda (op.cit., pp.327-375), no qual é feita uma abordagem muito mais completa da doutrina estóico-cristã, não só de D. Francisco Manuel de Melo, mas dos séculos XVI e XVII em geral.

${ }^{298}$ Zanta, L. La Renaissance du Stö̈cisme au XVI ${ }^{e}$ siècle, op.cit., p.12.

${ }^{299}$ Para não sermos injustos, devemos ressaltar que Denise Carabin apresenta uma opinião um pouco mais crítica, embora continue a usar o termo ao longo de seu texto: "On appelle 'néo-stoïcisme' cette résurgence d'idées stoïciennes au $\mathrm{XVI}^{\mathrm{e}}$ siècle. Depuis L. Zanta, le terme désigne la doctrine stoïcienne antique assouplie et nuancée par le christianisme. Le terme n'appartient pas au XVI ${ }^{\mathrm{e}}$ siècle, qui utilise le terme «stoïque » en tant qu'adjectif ou substantif, bien que nous ayons rencontré aussi, chez Duplessis-
} 
nosso trabalho, evitaremos a utilização do termo, pois acreditamos que ele não esclarece nem acrescenta coisa alguma; ou melhor, ele torna as coisas ainda mais indeterminadas do que já são. Como pudemos notar, não seria conveniente nem mesmo falar de "estoicismo", devido às dificuldades em caracterizar os fragmentos de Zenon como uma escola filosófica; isso ficou a cargo dos autores posteriores. Mas mesmo estes, em particular os dos séculos XVI e XVII, não falam de "estoicismo"; o mais comum é se referirem aos "estóicos" ou à "filosofia", "doutrina" ou "seita estóica", 300 como veremos. Se não há ocorrências, entre os autores quinhentistas e seiscentistas que lemos, de "estoicismo", o que dizer, então, de "neo-estoicismo"?

A palavra "estoicismo", conforme registra o Dicionário Houaiss da língua portuguesa, deriva de "estóico + -ismo; cp.fr stoücisme (1688)". ${ }^{301}$ E no verbete "stoïcien, ienne" do Grand Robert de la langue française, lê-se o seguinte: "V. 1300; du lat. stö̈cus, grec stoikos, de stoa «portique»(du Pécile), lieu où enseignait Zénon de Citium"; e, no mesmo dicionário, para "stoïcisme", registra-se: “n. m. - 1688, La Bruyère; de stö̈que". ${ }^{302}$ Portanto, o termo teria sido usado pela primeira vez, em francês e derivado de stö̈que, em 1688 por La Bruyère, ou seja, apenas em fins do século XVII. Mesmo assim, no Vocabulário Português e Latino de Bluteau, publicado já no século XVIII, não há a palavra "estoicismo", e sim: "ESTOICOS, Estôicos, ou Stoicos. Philosophos, assi chamados do Portico. Estoa na Cidade de Athenas, onde faziaõ suas academias, ou conferencias. (...) A seita dos Estoicos. Secta Stoica (...). Estoico. Homem severo, austero". ${ }^{303}$ Os textos que estudamos são anteriores a La Bruyère, datando da segunda metade do século XVI até meados do século XVII. Neles, como dissemos, não encontramos nenhuma ocorrência de "estoicismo" e, por isso, evitaremos usar esse substantivo quando tratarmos desses escritos quinhentistas e seiscentistas. Quanto ao termo "neo-estoicismo", se já não bastasse depender de estoicismo, parecenos ainda mais anacrônico e inadequado, pois ele não explica nem significa nada do que pudemos verificar nas obras dos séculos XVI ou XVII. Os autores desse período não

\footnotetext{
Mornay, chez J. Bodin et chez Montaige le mot «stoïcien »" (Les idées stö̈ciennes dans la littérature morale des XVI et XVII siècles (1575-1642), op.cit., p.20).

${ }^{300}$ Francisco de Quevedo é um dos autores que mais divulga a palavra "seita" em seus escritos, p.ex.: "La secta de los estoicos, que entre todas las demás miró con mejor vista a la virtud, y por esto mereció ser llamada seria, varonil y robusta" ("Nombre, Origen, Intento, Recomendación y Descendencia de la Dotrina Estoica". In: Obras completas. Tomo I. 6ª ed. Madrid: Aguilar, 1992, p.1085).

${ }^{301}$ Dicionário Houaiss da Língua Portuguesa. Rio de Janeiro: Objetiva, 2001, p.1257.

${ }^{302}$ Le Grand Robert: Dictionnaire alphabétique et analogique de la langue française. $2^{e}$ éd. entièrement rev. et enrichie par Alain Rey. 9 v. Paris: Le Robert, 1991.

${ }^{303}$ Vocabulario Portuguez, e Latino, op.cit., verb. "estoicos".
} 
demonstram jamais se considerarem "novos estóicos", mas cristãos que têm algum interesse na doutrina estóica, e ainda menos parecem querer criar uma escola "neoestóica”. Aliás, não se encontra nos textos da época nenhum rastro de neoqualquer.

Feita tal "errata", vejamos algumas condições que propiciaram aos autores quinhentistas e seiscentistas um contato com a doutrina estóica. Não pretendemos detalhar as edições dos séculos XVI e XVII das obras dos estóicos ou daquelas que divulgaram sua filosofia. Nossa intenção é apenas destacar que esta filosofia só ganhou espaço porque houve um grande aumento no número de edições e traduções daquelas obras. ${ }^{304}$ Para exemplificar, tomaremos por base o sintético catálogo de Pierre-François Moreau, ${ }^{305}$ acrescentando a ele as informações que julgarmos pertinentes.

Até o século XIV, as lições estóicas circularam muito pouco, principalmente devido à dificuldade de acesso às fontes, que se restringiram, principalmente, a Cícero e Sêneca, e, ainda assim, a um número reduzido de textos desses autores. Para ilustrar, vale destacar o que afirma Blüher, pois, embora se refira a Sêneca e especialmente ao mundo hispânico, nos parece um bom resumo da situação da filosofia estóica em geral até o século XIV:

Por eso, el redescubrimiento de Séneca en los siglos XIII y XIV en España no llevó todavía a un contacto profundo con sus ideas y obras; Séneca como filósofo estoico no fue descubierto por la Edad Media española, y su verdadera esencia permaneció oculta. A la luz entrecortada de los escritos apócrifos y fuentes indirectas, apareció la imagen de Séneca borrosa y deformada: mitad maestro de sabiduría práctica del mundo, mitad instructor de moral política. ${ }^{306}$

Já que se mencionou Sêneca, é justamente ele o estóico mais editado, traduzido e lido nos séculos XVI e XVII. A primeira edição crítica de sua Opera Omnia, como sabemos, ficou a cargo de Erasmo (Basiléia, 1515). Como diz Blüher, essa edição "se debe estimar tanto más cuanto que hasta el final del siglo XVI fue la

\footnotetext{
${ }^{304}$ Para informações mais detalhadas sobre as edições dos autores antigos no século XVI, veja-se Denise Carabin, Les idées stö̈ciennes dans la littérature morale des XVI et XVII siècles (1575-1642), op.cit., pp.39-61; sobre as traduções: Léontine Zanta, La Renaissance du Stoïcisme au XVI siècle, op.cit., pp.129-147. Entretanto, essas informações estão mais voltadas para aos autores franceses. Com relação ao mundo ibérico, um estudo completo sobre as edições e traduções de obras dos estóicos (em especial Sêneca, mas não só) e de seus divulgadores, é o já citado Séneca en España de Blüher (ver, particularmente, pp.223-249 e pp.418-426).

${ }_{305}$ "Les trois étapes du stoïcisme moderne". In: Le stö̈cisme au XVI et au XVII siècle, op.cit., pp.11-15.

${ }^{306}$ Séneca en España, op.cit., p.109.
} 
única edición crítica que, completada y corregida, quedó disponible en el mercado del libro, también en España", ${ }^{307}$ Seguindo uma ordem cronológica, vale lembrar também o comentário de Calvino ao De clementia, publicado em $1532 .{ }^{308}$ Das edições de Sêneca posteriores a Erasmo, pode-se citar a de Marc Antoine Muret (Roma, 1585) e aquela que é a mais importante e a mais utilizada no século XVII: a de Justo Lípsio (Antuérpia, 1605). ${ }^{309}$ Sobre a relevância desses dois autores, não só para a revitalização de Sêneca, mas da doutrina estóica de um modo geral, afirma Blüher:

Resumiendo, se puede afirmar que no fue el Humanismo español, sino el francés y el belgo-holandés, el que, en particular con las obras de Muret y Lipsio, revalorizó la importancia filosófica de Séneca y convirtió los escritos de este moderado estoico en fundamento de un estoicismo cristiano. (...) los humanistas trataron de rehabilitar la antigua Stoa como sistema filosófico, armonizándola posteriormente con el dogma cristiano (...). ${ }^{310}$

Outro estóico fundamental para os autores quinhentistas e seiscentistas é Epicteto. Isso se comprova pelo grande número de edições e traduções do Encheiridon, em especial. A primeira versão latina do Encheiridon é a de Policiano, publicada em Veneza (1498); será ela a principal referência de todas as edições seguintes, pois, como afirma Léontine Zanta, "pendant près d'un demi-siècle elle servira de base à tous les traducteurs ou commentateurs d'Épictète". ${ }^{311}$ Em 1535, também em Veneza, Victor Trincavelli adicionará ao Manual de Epicteto a primeira edição das Diatribes. Numerosas são as traduções posteriores, podendo ser mencionadas a de Hieronymus Wolf (1563), a de Guillaume du Vair (por volta de 1585), cujo "prefácio" é a primeira versão da Philosophie morale des stö̈ques (texto que analisaremos entre as fontes da

\footnotetext{
${ }^{307}$ Idem, p. 235 .

${ }^{308}$ Léontine Zanta, em seu capítulo "Le Stoïcisme et la Réforme", trata das relações entre os reformadores e a doutrina estóica (La Renaissance du Stö̈cisme au XVI siècle, op.cit., pp.47-73). Além disso, especificamente a respeito das idéias estóicas em Calvino, há o texto de Pierre-François Moreau, "Calvin: fascination et critique du stoïcisme", que demonstra que não se pode falar nem de uma adesão nem de uma rejeição de Calvino frente ao estoicismo (Le stö̈cisme au XVI et au XVII siècle, op.cit., pp.51-64). 309 "Pero el punto culminante de esta actividad editora, que se desarrolló con extrema rapidez en el espacio de dos décadas desde 1585, lo constituyó la edición monumental, con comentarios filosóficos, de Lipsio (Amberes, 1605 y ed. posteriores), que llegó a ser la edición más importante del siglo XVII." (Blüher, K. A. Séneca en España, op.cit., p.418). A respeito das edições de Sêneca a partir de 1585 e as suas traduções castelhanas, vejam-se as informações de Blüher (Idem, pp.418-426).

${ }^{310}$ Idem, p.405.

${ }^{311}$ La Renaissance du Stö̈cisme au XVI siècle, op.cit., p.139.
} 
doutrina estóico-cristã), e a de Francisco Sánchez de las Brozas, Dotrina del estoico filósofo Epicteto (Salamanca, 1600), considerada por Blüher "el primer documento de importancia del Neoestoicismo en España". ${ }^{312}$ Outras duas traduções espanholas do Encheiridon merecem ser citadas: a de Gonzalo Correas (Salamanca, 1630) e a conhecida tradução em verso de Francisco de Quevedo, Epicteto y Phocilides (1635), bastante dependente da versão de Sánchez de las Brozas.

De Marco Aurélio, em sintonia com a modesta recepção das Meditações entre os autores quinhentistas e seiscentistas, são poucas as edições e traduções e, por isso, fazemos menção apenas à de Xylander, em 1559.

Dos divulgadores da doutrina estóica, como vimos, Diógenes Laércio talvez seja o principal, e a sua edição mais conhecida é a tradução latina de Ambrogio Traversari, feita entre 1424 e 1453, e que apareceu, posteriormente, numa edição corrigida por Benedetto Brognoli (Veneza, 1475). Nas palavras de Pierre-François Moreau, "c'est cette traduction qui sera longtemps classique, plus que l'original grec même (et elle sera imprimée avant lui)". 313

Comparável a Diógenes Laércio, outro grande difusor da filosofia estóica foi Cícero. A sua relevância para a res literaria quinhentista e seiscentista já foi tantas vezes reafirmada que não nos parece preciso repisá-la mais uma vez. Além disso, são muitas as edições e traduções de Cícero, e extrapolaria os limites deste trabalho prenderse ao detalhamento de todas elas. Seguindo Léontine Zanta, somente referiremos, para exemplificar, algumas de suas obras traduzidas e que contribuíram para a divulgação das lições estóicas: o De Officiis (por David Miffaut, 1502); o De Legibus (por Jehan Collin, 1541); as Tusculanae Disputationes (por Estienne Dolet, Lyon, 1543); o Somnium Scipionis (por Pierre Saliat, Lyon, 1543); e o De Natura Deorum (por Le Fèvre, 1581). ${ }^{314}$ Além dessas mencionadas por Zanta, não podemos nos esquecer de algumas versões que circularam na península ibérica nos séculos XV e XVI. ${ }^{315}$ Em 1422, o bispo D.Alfonso de Cartagena vulgarizou o De Senectude e o De Officiis, impressos em Sevilha em 1501. Ainda na primeira metade do século XV, Gonzalo de la Caballería publicou duas traduções castelhanas de obras de Cícero: De los ofícios e De

\footnotetext{
${ }^{312}$ Séneca en España, op.cit., p.370. Sobre Francisco Sánchez de las Brozas, julgado por Blüher como o introdutor do "Neo-estoicismo" na Espanha, ver pp.368-390.

313 "Les trois étapes du stoïcisme moderne", op.cit., pp.12-13.

${ }^{314}$ La Renaissance du Stoïcisme au XVI siècle, op.cit., pp.129-130.

${ }^{315}$ Quanto às traduções dos textos de Cícero na península ibérica nos séculos XV e XVI, devemos tais informações a Flávio Antônio Fernandes Reis, que nos permitiu que consultássemos sua dissertação ainda inédita: $O$ "Sonho de Scipião em lingoagẽ portuguesa": Acerca da recepção de tratados morais de Cícero no Portugal quinhentista.
} 
la amistad. Também em língua castelhana, foram vulgarizados pelo monge cisterciense Angel Cornejo, por volta de 1548, os textos do De Senectude, do De Officiis e dos Paradoxa. Em Amberes, Francisco de Támara publicou, em 1546, a seguinte compilação: Libros de Marco Tulio Ciceron en que tracta De los officios, De la Amicitia, y De Senectud. Com la Economica de Xenephon, todo nuevamente traduzido de Latin en Romance Castellano. Essa compilação foi reimpressa em 1549, em Alcalá, acrescentando-se àqueles textos as traduções de Juan Jarava: Los Paradoxos e o Sueño de Scipion. Esse conjunto de traduções de Támara e Jarava foi publicado novamente em Amberes em 1550 e, finalmente, em Salamanca em 1582. Quanto a Portugal, desde o século XV, também foram vulgarizados alguns desses tratados de Cícero mencionados: o Livro dos ofícios por D. Pedro de Coimbra, o Tratado da velhice por Vasco Fernandes de Lucena, e o Tratado da amizade traduzido pelo Frei João da Verba. No século XVI, podemos citar as traduções de Duarte de Resende, que vulgarizou em língua portuguesa o De Amicitia, os Paradoxa e o Somnium Scipionis (Coimbra, 1531); e aquela de Damião de Góis do Cato Maior ou De Senectude (Veneza, 1538).

Pois bem. Como declaramos, esse foi apenas um breve resumo das condições "materiais" que permitiram aos autores dos séculos XVI e XVII conhecerem algumas das fontes da filosofia estóica. Passaremos, agora, ao que julgamos mais importante: a análise de alguns dos textos quinhentistas e seiscentistas que foram fundamentais na divulgação dos preceitos estóicos e que tiveram como um de seus principais objetivos conciliar esses preceitos com a doutrina cristã.

Para começar, é necessário ressaltar que a referida tentativa de conciliação entre a doutrina estóica e a cristã já existia nos escritos dos Padres da Igreja, como bem demonstram Léontine Zanta ${ }^{316}$ e Michel Spanneut. ${ }^{317}$ Nas palavras de Émile Bréhier, "il serait aisé de montrer par exemple que les écrivains chrétiens du $\mathrm{III}^{\mathrm{e}}$ au $\mathrm{V}^{\mathrm{e}}$ siècle empruntèrent au Stoïcisme tous les préceptes moraux qu'ils ne trouvaient pas dans les livres canoniques". 318

Mencionemos, pois, dois exemplos. Uma questão essencial no debate entre estóicos e cristãos é a noção de livre-arbítrio. Para os filósofos da Stoa, o Fatum determinaria todas as coisas que acontecem e, até mesmo, as "coisas divinas". Diante disso, Santo Agostinho, refletindo sobre algumas idéias provenientes dos estóicos,

\footnotetext{
${ }^{316}$ Ver o capitulo "Premier essai d'adaptation du stoïcisme au christianisme avec les Pères de l'Église" (Idem, pp.99-122).

${ }^{317}$ Le stö̈cisme des pères de l'Église de Clément de Rome à Clément d'Alexandrie, op.cit.

318 "Introduction", Les Stoïciens, op.cit., p.LX.
} 
coaduna a vontade e a liberdade humana com a presciência divina (que não está prédeterminada por nada além da própria vontade de Deus): ${ }^{319}$

\begin{abstract}
Non est autem consequens, ut, si Deo certus est omnium ordo causarum, ideo nihil sit in nostrae uoluntatis arbitrio. Et ipsae quippe nostrae uoluntates in causarum ordine sunt, qui certus est Deo eiusque praescientia continetur, quoniam et humanae uoluntates humanorum operum causae sunt; atque ita, qui omnes rerum causas praesciuit, profecto in eis causis etiam nostras uoluntates ignorare non potuit, quas nostrorum operum causas esse praesciuit (De Ciuitate Dei, V, IX). ${ }^{320}$
\end{abstract}

Como veremos, esse problema será retomado pelos autores dos séculos XVI e XVII e será um dos pontos centrais (e mais difíceis de serem "costurados") na busca por uma harmonização entre a filosofia estóica e a cristã.

Outro ponto chave para tal conciliação será a apatheia estóica frente à esperança dos mártires cristãos. Desde Santo Agostinho (De Ciuitate Dei, V, XVIII) e Tertuliano (Ad Martyres, II), por exemplo, já se discutia essa questão que afasta as doutrinas e terá que ser amarrada pelos estóico-cristãos. Zanta resume bem o problema e também a solução daqueles Pais da Igreja:

Ce mépris des biens extérieurs, cette constance du sage, que nous retrouvons chez le chrétien, n'est plus l'ataraxie stoïcienne, ni l'orgueilleux défi jeté à la nature humaine, ni le triomphe sans merci de la raison sur la sensibilité. Non, ce qui anime le courage des martyrs, c'est l'espérance ; ce qui permet au saint mieux qu'au sage de mépriser tous les biens de la terre, c'est l'amour de Dieu et l'assurance qu'il retrouvera d'autres biens supérieurs. ${ }^{321}$

\footnotetext{
${ }^{319}$ Cf. Léontine Zanta, La Renaissance du Stö̈cisme au XVI siècle, op.cit., p.108.

320 "Mas pelo facto de a ordem das causas estar determinada para Deus, não se conclui que nada depende do arbítrio da nossa vontade. É que as nossas próprias vontades pertencem à ordem causal, certa para Deus e contida na sua presciência. As vontades humanas são efectivamente as causas das acções humanas, e por conseguinte aquele que previu todas as causas das coisas não pôde ignorar, entre as causas, as nossas próprias vontades, pois que previu as causas das nossas acções" (A Cidade de Deus. Tradução, prefácio, nota biográfica e transcrições de J. Dias Pereira. $2^{\mathrm{a} e d . ~ L i s b o a: ~ F u n d a c ̧ a ̃ o ~ C a l o u s t e ~}$ Gulbenkian, 1996, p.489).

${ }^{321}$ Idem, p. 116.
} 
Isso posto, é preciso fazer a leitura propriamente dita das fontes estóico-cristãs dos séculos XVI e XVII. É claro que não poderíamos analisar, neste estudo, todas as obras. Por isso, selecionamos alguns textos dos autores mais representativos: Justo Lípsio, Guillaume du Vair, Pierre Charron, Francisco de Quevedo e D. Francisco Manuel de Melo. Tal exposição não pretende sistematizar algo que, em si, era pouco sistemático, mas colocar diante dos olhos uma certa afinidade de elementos estóicocristãos, que são fundamentais para uma compreensão mais ampla da poesia e da prosa de fins do século XVI até, pelo menos, meados do século XVII.

Um texto de grande repercussão nos séculos XVI e XVII ${ }^{322}$ e repleto de debates de cunho estóico foi o De constantia libri duo de Justo Lípsio, ${ }^{323}$ publicado em 1584 em Antuérpia. Devido ao seu papel fundamental, vale a pena determo-nos um pouco em algumas das discussões do tratado.

O De Constantia ${ }^{324}$ é um diálogo de caráter consolatório, cujos personagens são Lipsius e seu amigo Langius. Diante de um contexto turbulento (guerra dos espanhóis em Flandres, guerras religiosas, fome, epidemias etc.), Lipsius (o personagem) almeja fugir e se exilar em Viena. Porém, quando está partindo de Flandres, decide visitar seu amigo Langius, e este tenta persuadir Lipsius a não fugir, mas enfrentar, com constância, os males públicos. O principal intento do tratado é, como se verifica logo nos capítulos II e III do livro I, mostrar que fazer longas viagens não traz nenhum proveito para aquele que sofre com males interiores (que, como dizem os estóicos, são os únicos que realmente importam); ao contrário, viajar somente expõe

\footnotetext{
${ }^{322}$ São muitas, e em diversas línguas, as traduções quinhentistas e seiscentistas do De Constantia. Tendo em vista os objetivos do nosso trabalho, podemos lembrar, por exemplo, a tradução castelhana do século XVII: Libro de la Constancia de Iusto Lipsio. Traducido de latín en castellano por Juan Baptista de Mesa. Sevilla: M. Clauijo, 1616.

${ }^{323}$ São várias as obras que tratam de Justo Lípsio e não seria possível citar todas aqui. Para uma abordagem inicial da doutrina estóica nos escritos de Lípsio, relembremos dois estudos que já mencionamos: Saunders, J.L. Justus Lipsius: The Philosophy of Renaissance Stoicism, op.cit.; e Lagrée, J. Juste Lipse et la Restauration du Stö̈cisme, op.cit.

${ }^{324}$ Foram duas as edições do tratado que mais consultamos e que utilizaremos como referências no nosso trabalho. A primeira, em ordem cronológica de publicação, é uma tradução francesa anônima de 1592: Les Deux Livres de la Constance: Esquels en forme de devis familier est discouru des afflictions, et principalement des publiques, et comme il se faut résoudre à les supporter. Traduction anonyme du latin. Edition de Tours (1592). Paris : Noxia, 2000. A segunda serviu como nossa principal fonte do texto latino: Iusti Lipsi De Constantia Libri Duo, Qui alloquium pracipuè continent in Publicis malis. Antuerpiæ: Ex Officina Plantiniana, Apud Ioannem Moretum, 1599. Serão essas, portanto, as versões integrais do texto utilizadas, cotejando-se, sempre que possível, com a edição bilíngüe (latim-francês) e parcial de Jacqueline Lagrée, que traduziu grandes trechos do De Constantia (Juste Lipse et la Restauration du Stö̈cisme, op.cit., pp.123-160), além das diversas citações desse tratado de Lípsio em muitos outros estudos.
} 
tais males e não os cura, pois não adianta fugir dos lugares, mas sim das "paixões". 325 As viagens não são remédios: elas, na verdade, intensificam as "doenças da alma"; o único remédio para estas é aquele que provém da sapiência e da constância: deve-se mudar de "ânimo", não de lugar. ${ }^{326}$

A constantia, ${ }^{327}$ conceito central no tratado de Lípsio, é assim definida: "chamo de constância a uma resistência reta e imóvel da alma que não é aumentada nem diminuída pelas coisas exteriores ou fortuitas". ${ }^{328}$ Para se alcançar a firmeza interior que a constância proporciona, é preciso se guiar pela "reta razão" (orthos logos, recta ratio) e não pela "opinião" (doxa, opinio). A ratio tem uma origem divina, como Sêneca afirmou: "Ratio autem nihil aliud est quam in corpus humanum pars diuini spiritus mersa" (Epistulae ad Lucilium, LXVI, 12); enquanto que a opinio é apenas uma sombra e vã imagem da razão: "Comme le navire vide et délaissé est demené sur la mer par tout vent, ainsi l'entendement vague se jette en nous, pour ce qu'il n'est point affermi par la charge et contrepoids de la raison", 329

No capítulo VII do livro I, Langius explica a Lipsius aquilo que pode perturbar a constância, retomando alguns ensinamentos dos estóicos (aos quais já nos referimos). Uma opinião a ser cortada pela raiz é aquela que causa a confusão entre os bens e os indiferentes preferíveis e os males e os indifirentes a serem evitados. Como afirma Jacqueline Lagrée, "les faux biens et faux maux (falsa bona et falsa mala) sont toutes les choses externes et fortuites qui affectent bien notre être mais ne concernent pas

\footnotetext{
${ }^{325}$ Utilizamos o termo "paixão" na acepção predominante da época, como uma "perturbação", tanto do corpo como da alma. No Vocabulário Português e Latino do Bluteau, a palavra é assim definida: "Movimento do appetite fenfitivo, occafionado da imaginação de hum bem, ou de hum mal apparente, ou verdadeyro, que perturba o eftado interior, \& exterior do homem, \& lhe tira a fua tranquilidade natural. (...) $\mathrm{Na}$ opinião dos Eftoicos a felicidade do homem eftá em não ter payxão algũa (...). Paixão defordenada, violenta, cega, contraria à razão. Animi perturbatio (...). Moderar, reprimir, domar as paixões. Ser fenhor das fuas paixões" (Vocabulario Portuguez, \& Latino, op.cit., verb. "paixão"). Vale a pena destacar também a etimologia da palavra: "ETIM lat.tar. passǐo, ōnis 'paixão, passividade; sofrimento', pelo vulg.; ver pass-; f.hist. sXIII paixon, sXIII paxon, sXIV payxõ, sXIV payxõoes, sXV paixão, sXV passiom, sXV paxam 'martírio', sXV paixões, sXV passõoes 'sentimento"” (Dicionário Houaiss da Lingua Portuguesa, op.cit., p.2106).

${ }^{326}$ De Constantia, I, 2-3.

${ }^{327}$ Para uma análise inicial sobre a constância, virtude tipicamente estóica, veja-se o texto de Jacqueline Lagrée: "La vertu stoïcienne de constance" (In: Le stoïcisme au XVI et au XVII" siècle, op.cit., pp.94116).

328 "Constantiam hic appello rectum et immotum animi robur non elati externis aut fortuitis non depressi" (De Constantia, I, 4).

${ }^{329}$ Idem, I, 5, p.32. A página citada é da edição, já mencionada, da tradução francesa anônima de 1592. Colocamos o número da página, nesse caso, porque citamos o texto francês; nos outros casos, que são todas as nossas outras menções ao De Constantia, somente referiremos o livro e o capítulo do tratado. No texto latino da edição de 1599 , esse mesmo trecho aparece da seguinte forma: "Vt nauis vacua \& inanis circumagitur in mari omni vento: sic in nobis vaga illa mens, quam pondus $\&$ tamquam saburra Rationis non stabiliuit".
} 
proprement notre âme et son bien, c'est à dire la vertu ou l'honnête". ${ }^{330}$ Dentre os males, os públicos, tais como a guerra, a peste, a fome, a tirania e os massacres, são, com certeza, mais graves que os males privados, como a dor, a indigência, a desonra e a morte, pois enquanto estes são "domésticos" aqueles atingem um número muito maior de pessoas e, por isso, causam reações passionais contagiosas e nefastas, que, à primeira vista, podem ser confundidas com as virtudes.

Outro tópico caro aos estóicos que aparece no De Constantia é aquele que trata da pátria do sábio. Para este, seu verdadeiro país é onde quer que ele esteja, pois, como dizia Sócrates, o sábio é cidadão do mundo. ${ }^{331}$ Mas, em termos mais precisos, ou seja, cristãos, o verdadeiro e natural país do sábio estóico-cristão é o céu, ao qual se deve aspirar sempre. $^{332}$

Langius, em mais um diálogo crítico com a doutrina estóica (em especial, com o De Clementia de Sêneca), ensina a Lipsius a diferença entre a miseratio e a misericordia. A primeira é um vício de um "ânimo" fraco e pusilâmine que se deixa abater diante do mal alheio; enquanto que a segunda é uma inclinação do "ânimo" que o faz suportar a miséria ou a tristeza alheia. ${ }^{333} \mathrm{O}$ que em Lípsio define-se como miseratio ("uitium pusilli minutique animi, ad speciem alieni mali collabentis"), Sêneca tinha definido como misericordia ("uitium pusilli animi ad speciem alienorum malorum succidentis" ${ }^{334}$ ), demonstrando uma inversão de definições que visa a preservar a filosofia cristã.

Logo a seguir, no capítulo XIII, tem início a discussão fundamental acerca da Providência, que implica o Fatum e o livre-arbítrio. Como vimos, Santo Agostinho já tinha refletido sobre o problema. Agora é a vez de Lípsio. Há quatro formas de combater os males públicos: pensar que eles são enviados por Deus, que são necessários por causa do destino, que são úteis ou que não são perniciosos nem novos ou surpreendentes. Para que esses motivos nos consolem, precisamos, antes, admitir a existência de Deus e sua providência. Esta é o cuidado divino, vigilante e perpétuo, pelo qual ele vê tudo, está em tudo e conhece tudo, conduzindo e governando todas as coisas

\footnotetext{
330 "La vertu stoïcienne de constance", op.cit., p.101.

${ }^{331}$ De Constantia, I, 9. Essa suposta afirmação de Sócrates foi muito divulgada entre os autores antigos, como, por exemplo, lemos em Cícero: "Socrates quidem cum rogaretur, cuiatem se esse diceret, 'mundanum' inquit; totius enim mundi se incolam et ciuem arbitrabatur" (Tusculanea Disputationes, V, XXXVII, 108).

${ }^{332}$ De Constantia, I, 11.

333 Idem, I, 12.

${ }^{334}$ De Clementia, II, V, 1.
} 
através de uma ordem imutável, que nós não conhecemos. ${ }^{335}$ Com exceção do pecado, nada acontece que não tenha origem em Deus. Por isso, Lípsio afirma, citando Sêneca, que a verdadeira liberdade consiste na obediência a Deus: "In regno nati sumus, deo parere libertas est" (De Vita Beata, XV, 7). ${ }^{336}$ Contudo, vale ressaltar que embora no texto de Lípsio essa frase de Sêneca seja usada como se tivesse sido escrita por um autor cristão, é evidente que o deus de que fala o filósofo cordovês não é o Deus cristão, pois os deuses gregos e romanos estão subordinados à Moira e ao Fatum, ao passo que o Deus dos cristãos é absoluta liberdade refletida na luz da Graça que ilumina o livrearbítrio humano.

As considerações a respeito da segunda forma de se combater os males públicos levam a um debate explícito com a filosofia estóica, motivado pela noção de Fatum. A discórdia principal se assenta no fato de que, para os estóicos, Deus também estaria sujeito ao Destino, como Crisipo e Sêneca o teriam afirmado. Eis o que diz o segundo: "quidquid est quod nos sic uiuere, sic mori iussit, eadem necessitate et deos alligat. Inreuocabilis humana pariter ac diuina cursus uehit. Ille ipse omnium conditor et rector scripsit quidem fata, sed sequitur; semper paret, semel iussit" (De Prouidentia, V, 8). ${ }^{337}$ Para Lípsio, ou melhor, segundo Langius, o Fatum é o que Deus disse e comandou e, portanto, está submetido à vontade divina. É fundamental distinguir a Providência e o Destino: aquela é uma força (universal e indivisível), que está em Deus, de ver, saber e governar tudo; enquanto o Fatum "desce" sobre todas as coisas e é considerado em cada uma delas, sendo uma divisão da Providência, distintamente repartida. Enfim, a Providência está em Deus e é atributo apenas dele; o Destino está nas coisas e é apropriado somente a elas. ${ }^{338}$

No capítulo XX do livro I do De Constantia, o Fatum estóico é amplamente discutido e contraposto às verdades cristãs. O Destino verdadeiro (ou seja, cristão) é distinguido do estóico, pois: $1^{\circ}$ ) Os estóicos submetem Deus ao Destino, mas, em termos cristãos, o Destino é que está submetido à divindade; $2^{\circ}$ ) Os estóicos atribuem eternidade a um fluxo e suite de causas naturais, já os cristãos acreditam que as causas

\footnotetext{
${ }^{335}$ De Constantia, I, 13.

${ }^{336}$ Idem, I, 14.

${ }^{337}$ Idem,I, 18. O trecho citado do De Prouidentia é assim traduzido por Ricardo da Cunha Lima: "Seja o que for que nos ordenou a viver assim, a morrer assim, sob a mesma imperiosa necessidade, ata também os deuses. Um fluxo irrevogável tranasporta de modo igual as coisas humanas e divinas: o próprio criador e condutor de todas as coisas escreveu, sem dúvida, os fados, mas os segue. Para sempre obedece, uma vez ordenou" (Sobre a Divina Providência. Tradução, introdução e notas de Ricardo da Cunha Lima. São Paulo: Nova Alexandria, 2000, p.57).

${ }^{338}$ De Constantia, I, 19.
} 
secundas não são nem eternas nem nascidas com o mundo; $3^{\circ}$ ) A doutrina estóica, diferentemente da cristã, subtrai de todas as coisas o contingente e o fortuito; e $4^{\circ}$ ) Os filósofos da Stoa "forçam" a vontade humana, enquanto na filosofia cristã destino e liberdade da vontade humana estão perfeitamente conciliados. Assim, são essas as divergências centrais entre as duas doutrinas. A partir dessa diferenciação é que se pode afirmar que o Destino é a primeira causa, que, no entanto, não elimina as causa segundas, entre as quais está a vontade humana. Por isso, pecamos livremente e também necessariamente, porque, com o livre-arbítrio, podemos aceitar ou não a disposição divina, mas sem poder jamais lhe resistir ou impedi-la. ${ }^{339}$

São essas as principais questões que queríamos destacar no De Constantia de Lípsio. Porém, para não deixar a exposição incompleta, mencionaremos algumas justificativas das outras duas maneiras de se combater os males públicos. A terceira, da utilidade desses males, desemboca numa reflexão sobre a finalidade das misérias: estas sempre visam a conduzir a algum bem, já que, providencialmente, exercitam, castigam e punem as pessoas ou, ainda, porque servem para conservar e ornamentar o universo. ${ }^{340}$ A quarta e última forma de combater os males públicos é entender que eles não são perniciosos nem novos ou surpreendentes. Não são nocivos, pois somente Deus pode ser juiz dos nossos pecados e, assim, não há como julgar as nossas faltas tomando por base o sentido humano: Deus tem outra balança e justiça. ${ }^{341}$ E tais males nunca serão “novos" se não nos deixarmos levar pela opinião, que sempre eleva e exagera as coisas, ${ }^{342}$ uma vez que as misérias e desgraças sempre foram e serão comuns a todos os homens e nações. ${ }^{343}$

Além do De Constantia, outros dois textos de Lípsio que tem uma relação direta com a doutrina estóica são a Manuductio ad Stoicam Philosophiam e a Physiologia Stoicorum, ambos publicados em 1604, em Antuérpia. Esses dois últimos tratados, mais a edição de Sêneca (1605), contribuíram para que a filosofia estóica fosse divulgada e debatida entre os autores seiscentistas: o Manual como um resumo da ética e a Physiologia como uma síntese da física. Entretanto, são bem menos numerosas as edições desses textos de Lípsio do que do De Constantia, o que parece indicar uma

\footnotetext{
${ }^{339}$ Idem, I, 20.

${ }^{340}$ Idem, II, 7-11.

${ }^{341}$ Idem, II, 16.

${ }^{342}$ Idem, II, 19.

${ }^{343}$ Idem, II, 26.
} 
circulação mais restrita (em especial, da Physiologia) no século XVII. ${ }^{344}$ Por tal motivo, a nossa análise da Manuductio e da Physiologia será mais breve e destacaremos apenas algumas questões pontuais que tenham relevância para nosso estudo, seguindo, em muitos aspectos, as considerações já feitas por Léontine Zanta, Blüher, Jacqueline Lagrée e Denise Carabin. ${ }^{345}$

A primeira parte do Manual de Lípsio começa com um esboço da história da filosofia antiga, que almeja demonstrar a superioridade da Stoa em relação às outras doutrinas (em particular, a dos peripatéticos), principalmente devido à semelhança entre a doutrina dos estóicos e a dos cristãos: "voyant plus loin que la morale, son auteur veut promouvoir le stoïcisme et le rapprocher, au niveau de l'histoire et du contenu, de la culture chrétienne, comme l'avait fait la tradition des Peres". ${ }^{346}$ A partir disso, Lípsio passa a expor a história da filosofia estóica. Suas principais fontes de erudição, segundo Zanta, são os Padres da Igreja e Diógenes Laércio. ${ }^{347}$ Para Lípsio, a filosofia antiga tinha uma origem divina, ainda mais a doutrina estóica; ${ }^{348}$ porém, a sabedoria divina ficou oculta nos filósofos antigos por causa do pecado original. ${ }^{349}$

Depois de considerações históricas como essas, a segunda parte do Manual é toda voltada para explicar algumas idéias da ética estóica. E examinaremos, aqui, as

\footnotetext{
${ }^{344}$ O Manual de Lípsio teve um certo sucesso editorial, como notamos pelas suas edições seiscentistas: em separado, o texto dos Manuductionis ad stoicam philosophiam libri tres foi publicado em Antuérpia (1604 e 1610), em Paris (1604) e em Leyde (1644). Além disso, foi publicado, é claro, na Opera Omnia de Lípsio (Antuérpia, 1637; Wesel, 1675).

345 Consultamos os textos latinos integrais da Manuductio ad Stoicam Philosophiam e da Physiologia Stoicorum na seguinte edição da "Obra Completa" de Lípsio: Opera Omnia. Tomus Quartus. Antuerpiæ: Ex Officina Plantiniana, Balthasaris Moreti, 1637. Porém, nossas citações se basearão, quase sempre, na edição parcial e bilíngüe de Jacqueline Lagrée, que editou e traduziu trechos da Manuductio e da Physiologia (Juste Lipse et la Restauration du Stö̈cisme, op.cit., pp.161-253), e nas menções que Zanta e Blüher fazem desses dois textos de Lípsio.

${ }^{346}$ Carabin, D. Les idées stö̈ciennes dans la littérature morale des XVI et XVII siècles (1575-1642), op.cit., p.778.

${ }^{347}$ La Renaissance du Stö̈cisme au XVI siècle, op.cit., p.189.

348 "tres scito universe eas esse, Barbaricam, Italicam, Graecanicam: nondum per homines aut capita, sed nationes et populatim distinctas. Barbaricam dicimus, quae extra Graeciam aut Italiam, et antiqüíssima quidem, fuit. Quidni antiquissima? cui a primo illo humani generis parente origo, imo a Deo ipso fuit. Quis enim alius Sapientiae hos radios, nisi ipsa Sapientia primum emiserit? Ille ut benigne imaginem sui homini infudit, sic et animi haec ornamenta sive adjumenta; et quidem pleniore tunc manu. Nam quis ambiget, quin ille, quem praesentia et alloquio suo dignatus est, qui nondum offenderat, et fruebatur amore divino; qui recens in natalibus magni mundi hujus erat; qui inspector cognitorque tot novorum operum caelo, terra, mari: quin is, inquam, sognitione varia, et interiore magis, fuerit perfusus ? (Manuductio ad Stoicam Philosophiam, I, 5). Citamos o trecho conforme Léontine Zanta, La Renaissance du Stö̈cisme au XVI siècle, op.cit., p.189, nota 1.

349 "Praesumendum est: atque etiam illud, eumdem labe peccati tenebrosum, lapsu a culmine felicitatis debilitatum, multa clari ejus luminis amisisse, quod in priore statu intus lucebat, foris allucebat. Antea ei unum opus, contemplatio, et vivere vix aliud erat, quam cogitare; at postquam felicitate, e tejus sede, excidit, labor accessit et cura corporis animique: et vix aliud mansit, quam velut e magno igne scintillae, atque eae occultae in fomite ingenii, et sub cinere sopitae" (Idem, I, 5). Cf. Zanta, L. op.cit., p.190, nota 1.
} 
explicações que julgamos mais relevantes. Na dissertação XIII do livro II, tem início a discussão sobre o fim último ou sumo bem, uma questão essencial na doutrina estóica. Para os gregos, o "fim" era o telos, num sentido filosófico diferente do sentido ordinário que significava a efetuação e o acabamento da coisa iniciada. Lípsio cita diversos autores antigos sobre a noção de fim (ou finalidade), como Aristóteles, por exemplo, que dizia que o conhecimento do fim é útil e de grande importância para a vida: assim como os arqueiros têm um alvo, nós buscaremos melhor o que convém se tivermos um objetivo ou finalidade (V. Ética a Nicômaco, I, 1, 1094b, 22). Se para o mesmo Aristóteles o fim último seria a felicidade (Idem, I, 5), para os estóicos, o objetivo (scopus) proposto é outro: o verdadeiro fim é perseguir a felicidade ("finem vero esse felicitatem assequi"). ${ }^{350}$ O finem verum dos estóicos é secundum Naturam vivere, conforme o título da dissertação XIV, onde são referidas as diversas interpretações que foram desenvolvendo o tópico. Reportando às Éclogas de Estobeu e às Vidas de Diógenes Laércio, Lípsio identifica a origem da expressão no convenienter vivere (homologoumenos zen) de Zenon. Nesse sentido e abreviando ainda mais a expressão, é que, para Cícero, o sumo bem dos estóicos seria, simplesmente, a homologia ou a convenientiam (De Finibus, III, 21). ${ }^{351}$ A essa definição inicial de Zenon, Cleantes teria adicionado a natureza: convenienter naturae vivere, e, mais ainda, viver de acordo com a natureza comum. O que seria essa natura communis? É a Lei e a Razão universais presentes na totalidade do mundo e em suas partes, ou seja, é o próprio Deus. ${ }^{352}$ A tese seguinte é a de Crisipo: a natureza própria ao homem é a Razão, e deve-se viver em conformidade com a ratio perfecta. Para comprovar o que diz, Lípsio cita Sêneca: "Quum sola ratio perficiat hominem (id est perfecte bonum faciat) sola Ratio perfecta beatum facit" (Ep. ad Luc., LXXVI, 9). ${ }^{353}$ A quarta e última tese é aquela que define o fim último como "viver segundo a virtude", e está de acordo com as demais ("virtus rationem sequitur, haec naturam, ista Deum") e todas são verdadeiras, pois seguem e conduzem a Deus; e o verdadeiro sábio é aquele que imita Deus. Enfim, o soberano bem está na virtude, ou melhor, ela apenas é o Bem ("solam illam Bonum esse"). Por isso, a beatitude ou felicidade não depende de nada exterior ou da Fortuna, mas tão-somente da Virtus, conforme a célebre definição de Epicteto das coisas que estão em nós e

\footnotetext{
${ }^{350}$ Manuductio, II, 13. Citação do texto latino com base na edição de Jacqueline Lagrée, op.cit., p.172.

${ }^{351}$ Idem, II, 15.

${ }^{352}$ Idem, II, 16

${ }^{353}$ Idem, II, 17.
} 
depende de nós e as que não estão em nós e não dependem de nós (Encheiridon, I, 12). ${ }^{354}$

O resto da Manuductio de Lípsio trata dos paradoxos estóicos. Merece destaque a questão da apatheia, que Lípsio, seguindo Sêneca, recomenda que seja moderada:

\begin{abstract}
Mihi videtur, in commodo illo et vero intellectu, nempe Sapientem, non esse rigidum, durum, exsensum, exsortemque a dolore, metu, cupidine, laetitia: sed primis dumtaxat, incipientibusque, Sentiscere ea, et moveri quoque iis: sed reiicere, nec permoueri (Manuductio, III, 7). ${ }^{355}$
\end{abstract}

Esforçando-se para harmonizar as filosofias estóica e cristã, além da apatia “extrema”, Lípsio não aceita a idéia de que o sábio seja igual a Deus, ${ }^{356}$ nem a reprovação da compaixão (misericordia) ${ }^{357}$ e tampouco a justificação do suicídio; ${ }^{358}$ tópicos esses que determinaram, em grande parte, a ética estóica, embora já fossem questionados entre os próprios filósofos da Stoa.

Da Physiologia Stoicorum, tratado que teve bem menos repercussão que o De Constantia e a Manuductio, poucas são as discussões que poderiam enriquecer nosso trabalho. Seguindo o esboço de Denise Carabin, vejamos, em linhas gerais, o que comporta a Physiologia. São três livros: o primeiro tem 21 dissertações que tratam de Deus, do Destino e da Providência; o segundo tem 24 dissertações que concernem o mundo, sua formação, sua evolução e seu fim; o terceiro apresenta 19 dissertações sobre o homem e a alma. ${ }^{359}$ Desses livros, somente o primeiro teria um maior interesse para nossos objetivos; no entanto, os argumentos que usa Lípsio para tratar do Fatum e, conseqüentemente, da Providentia são, em última análise, os mesmos empregados no De Constantia. ${ }^{360}$ Não queremos, portanto, nos tornar repetitivos. ${ }^{361}$ Para ilustrar como há uma tentativa de conciliar as noções, não só da ética estóica, mas também da física, com a filosofia cristã, vale a pena mencionar a interpretação que Lípsio dá aos

\footnotetext{
${ }^{354}$ Idem, II, 18-20.

${ }^{355}$ Conforme citação de Blüher, Séneca en España, op.cit., p.400.

${ }^{356}$ Manuductio, III, 14.

${ }^{357}$ Idem, III, 19.

${ }^{358}$ Idem, III, 22-23.

${ }^{359}$ Les idées stö̈ciennes dans la littérature morale des XVI et XVII siècles (1575-1642), op.cit., p.778.

${ }^{360}$ Blüher, Karl Alfred. Séneca en España, op.cit., p.400.

${ }^{361}$ Para uma discussão acerca do Destino e a Providência na Physiologia Stoicorum, remetemos ao texto de Jacqueline Lagrée: "Juste Lipse: destins et Providence" (In: Le stö̈cisme au XVI et au XVII siècle, op.cit., pp. 77-93).
} 
princípios estóicos efficiens (Deus) e patiens (matéria): "propone una interpretación dualista al monismo estóico (...). Para él, la razón universal de los estóicos, que como principio activo, penetra todo el mundo y le da forma, no es inmanente sino transcendente a éste" (Cf. Physiologia, I, 4). ${ }^{362}$ Essa busca de conciliação fica ainda mais explícita quando é abordada a definição da física estóica de Deus como ignem artificiosum. Para Lípsio, tal idéia já existia no Antigo Testamento: "Enim vero ipse Moises imaginem istam Deo donat: et apparuisse sibi scribit in rubo ardente; Israelitis praevisse, in columna ignis; sed et Ignis consumens alibi appellatur". 363

Textos de um outro autor também expuseram e divulgaram ensinamentos da doutrina da Stoa, tentando coaduná-los com os dogmas cristãos: trata-se de Guillaume du Vair. ${ }^{364}$ Nossa análise abordará algumas questões presentes na Philosophie morale des stö̈ques (a datação da primeira edição do tratado é incerta: possivelmente, por volta de 1585) e no De la constance et consolation és calamitez publiques (Paris, 1594). Outros textos de Du Vair apresentam, implícita ou explicitamente, idéias provenientes da filosofia estóica, como, por exemplo, De la sainte philosophie (1587), mas nos restringiremos àqueles dois por se constituírem como os que dialogam, mais diretamente, com os preceitos estóicos.

A Philosophie morale des stö̈ques ${ }^{365}$ foi concebida por Du Vair como uma paráfrase à sua tradução do Manual de Epicteto e, mais do que isso, como um sumário da "disciplina moral" dos estóicos, conforme o próprio autor explica no prefácio "Au Lecteur Français":

Je vous avertis donc, et ceux qui le rencontreront, que ce n'est autre chose que le même Manuel d'Épictète, que j'ai mis en pièces, lesquelles j'ai transposées selon l'ordre que j'ai jugé le meilleur, rassemblées avec quelques préceptes, sentences et exemples d'autres de cette secte, et liées de petits discours que j'ai estimés propres pour y

\footnotetext{
362 Blüher, Karl Alfred. Séneca en España, op.cit., p.400.

${ }^{363}$ Physiologia, I, 6. Conforme a edição parcial de Jacqueline Lagrée, Juste Lipse et la Restauration du Stö̈cisme, op.cit., p.222.

364 A respeito do estoicismo em Du Vair, ver: Zanta, L. La Renaissance du Stö̈cisme au XVI siècle, op.cit., pp.241-331; Carabin, D. Les idées stö̈ciennes dans la littérature morale des XVI et XVII siècles (1575-1642), op.cit., pp.333-415; Tarrête, A. "Le stoïcisme chrétien de Guillaume Du Vair (1556-1621)". In: Stö̈cisme et Christianisme à la Renaissance, op.cit., pp. 93-116.

${ }^{365}$ Segundo Denise Carabin, o tratado de Du Vair teria sido o primeiro, em língua francesa, a comportar o termo "stoïques" no título (Les idées stoïciennes dans la littérature morale des XVI et XVII siècles (1575-1642), op.cit., p.337).
} 
éclaircir ce qui y était d'obscur: tellement qu'il peut servir à cette heure comme d'un sommaire de toute discipline morale des Stoïques. ${ }^{366}$

De acordo com Denise Carabin, pode-se resumir e esquematizar o conteúdo da obra da seguinte forma: na parte inicial (11 parágrafos), discute-se o fim ou objetivo do homem e define-se o bem; num segundo momento, que constitue a maior parte do tratado (55 parágrafos), indica-se a prudência como principal remédio contra as paixões e, além disso, explica-se o que são e como se originam as paixões, recomendando-se, em seguida, os remédios para várias delas; na terceira parte (24 parágrafos), são referidos os deveres em relação a Deus, aos outros e a si mesmo; e, para encerrar, um parágrafo é consagrado à "fillosofia” da acomodação e da conservação e outro (o último) fecha o texto com uma conclusão cristã, como se fosse uma prece ou oração. ${ }^{367}$

Destaquemos, pois, algumas questões presentes na Philosophie morale des stö̈ques. Du Vair começa afirmando que o fim do homem e de todos os seus pensamentos e movimentos é o bem e, por isso, devemos buscá-lo. O bem é o sequi naturam estóico, é "l'être et l'agir selon la nature", ou seja, consiste "en l'usage de la droite raison, - qui est à dire en la vertu, laquelle n'est autre chose que la ferme disposition de notre volonté à suivre ce qui est honnête et convenable". ${ }^{368}$ Esse bem próprio ao homem não é a saúde nem a riqueza, que, como "indiferentes", "sont rendues bonnes ou mauvaises selon l'esprit de l'homme en sait bien user, et sans lesquelles il ne laisse pas de pouvoir parvenir à sa fin". ${ }^{369} \mathrm{O}$ princípio e movimento das ações humanas são o entendimento e a vontade, cuja perfeição é justamente o bem que procuramos. A nosssa vontade só deve querer aquilo que está em nosso poder e depende de nós, o que está na alma e no espírito, pois o que não depende de nós tem como maîtresse a Fortuna. ${ }^{370}$ Em suma:

Nous conclurons donc par là ce propos que, puisque l'heur de l'homme dépend de son bien, que son bien est de vivre selon sa nature, que vivre

\footnotetext{
${ }^{366}$ Philosophie Morale des Stö̈ques. Édition annotée par G. Michaut. Paris : J. Vrin, 1945, p.61.

367 Cf. Carabin, D. Les idées stö̈ciennes dans la littérature morale des XVI et XVII siècles (15751642), op.cit., p.357.

${ }^{368}$ Philosophie Morale des Stö̈ques, op.cit., pp.63-64.

${ }^{369}$ Idem, p.65.

${ }^{370}$ Como afirma F.H. Sandbach, uma das idéias mais importantes e recorrentes nas Diatribes e no Encheiridon de Epicteto é a distinção entre aquilo que está sob nosso controle e aquilo que não está. O que o homem controla é apenas sua prohairesis: seu "propósito moral" ou sua capacidade de antecipação e escolha prévia, para que se faça o uso correto das "impressões externas", das phantasias (The Stoics, op.cit., p.165). Conforme, por exmeplo, Diatribes, I, 1; e Encheiridon, 1.
} 
selon sa nature, c'est de n'être point troublé de passions et se comporter envers toutes choses qui se présentent selon la droite raison, il nous faut, pour être heureux, purger notre esprit des passions et apprendre comme nous nous devons affectionner envers ce qui présente. ${ }^{371}$

O começo e o fim de todas as virtudes é a Prudência. Ela, como o escudo de Aquiles, nos permite avançar em direção ao bem e afastar o mal para longe de nós. ${ }^{372}$

E devemos iniciar essa busca pelo bem extirpando as paixões. Eis como estas são definidas, em termos estritamente estóicos, por Du Vair: "Nous appelons passions un mouvement violent de l'âme en sa partie sensitive, qu'elle fait ou pour suivre ce qui lui semble bon ou fuir ce qui lui semble mauvais". ${ }^{373}$ Todas as paixões nascem da fausse opinion. Para não nos perturbarmos com nada, devemos saber o que está em nosso poder e o que não está. Mas o que podemos controlar e o que não podemos? Explica, então, o autor: “nous avons en notre puissance l'approver, l'entreprendre, le désirer et le fuir, et en un mot toutes nos actions" e, ao contrário, "hors de notre puissance sont notre corps, nos richesses, la réputation et, en un mot, tout ce qui ne dépend point de notre volonté". Du Vair, porém, como um bom cristão, ameniza a tese da apatheia estóica: não devemos fugir ou desejar aquilo que está fora de nossa puissance, mas essa abstenção há de ser feita "avec une affection tempérée", isto é, sempre com moderação. ${ }^{374}$

A partir disso, defendendo a utilidade dos "preceitos", ${ }^{375} \mathrm{Du}$ Vair passa a enumerar uma série de regras para extirpar, ou melhor, moderar as paixões e resistir aos males. Para exemplificar, vejamos alguns preceitos. Contra a haine, ecoando o De Ira de Sêneca, recomenda-se como remédio pensar que tudo tem dois lados: um bom e outro ruim; nós é que devemos escolher por qual lado iremos tomar as coisas. Enfim, precisamos tornar dignos de serem amados aqueles que odiamos. ${ }^{376}$ Contra a fâcherie, há que se ter sempre em mente que "les biens de la terre sont comme les meubles d'une

\footnotetext{
${ }^{371}$ Philosophie Morale des Stö̈ques, op.cit., p.68.

${ }^{372}$ Idem, pp.68-69.

${ }^{373}$ Idem, p.69.

${ }^{374}$ Idem, p.73.

${ }^{375}$ Vale lembrar que a utilidade da filosofia ou moral "prática" (parenética) já tinha sido defendida por Sêneca contra os ataques dos filósofos que acreditavam apenas numa moral "teórica" (dogmática). Sêneca, diferentemente, afirmava serem de grande utilidade, para aqueles que ainda não são "sábios" (sophoi, sapientes), os preceitos, conselhos e máximas (Cf. Ep. ad Luc., XV, 94).

${ }^{376}$ Philosophie Morale des Stö̈ques, op.cit., pp.84-85.
} 
hôtellerie, dont nous ne nous devons soucier que tant que nous y sommes". ${ }^{377}$ Portanto, é preciso nos acostumar a "amar" (aimer) as coisas somente pelo que elas são e nada mais, pois é a opinião que nos atormenta mais do que as próprias coisas. Entre as choses fâcheuses mencionadas pelo autor, vale destacar o banimento; o remédio contra esse mal é a famosa idéia, tão cara aos estóicos, da pátria universal do sábio: "Toute terre est pays à l'homme sage, ou plutôt, nulle terre ne lui est pays. Son pays est le ciel où il aspire, passant ici-bas seulement comme par un pélerinage, et s'arrêtant aux villes et aux provinces comme en des hôtelleries". 378 Porém, mais do que civis mundi, o sábio estóico-cristão é peregrino na terra e cidadão do céu.

Como dissemos, na terceira parte da Philosophie morale des stö́ques, Du Vair trata dos offices ou deveres. Estes são "les effets de cette affection témprée de l'homme envers les autres choses du monde (...) comme qui dirait le devoir et la façon dont il s'y doit comporter". ${ }^{379}$ Entre os vários deveres em relação a Deus, aos outros e a si mesmo elencados pelo autor, citaremos apenas um (muito mais um "conselho"), que nos parece uma síntese de todos os outros:

Le plus profitable enseignement que vous puisse donner la philosophie pour toutes vos actions, c'est d'examiner soigneusement quel doit être le progrès et la fin de ce que vous entreprenez, et mesurer vos forces et voir comme elles sont proportionnées à vos desseins. ${ }^{380}$

Cristianizando a doutrina estóica, Du Vair conclui que, ante o poder da Fortuna sobre os acontecimentos, só nos resta "entreprendre avec prudence, poursuivre avec espérance et supporter ce qui arrive avec patience", e pedir a Deus "tout bon, tout sage et tout puissant", como faz o autor na sua oração final, ${ }^{381}$ que nos conduza sempre em direção ao bem, ou seja, àquilo que é verdadeiramente e que será eternamente bom. $^{382}$

Como percebemos, a Philosophie morale des stö̈ques é realmente uma tentativa de síntese da ética estóica, já adaptada ao cristianismo. O outro tratado de Du

\footnotetext{
${ }^{377}$ Idem, p.89.

${ }^{378}$ Idem, p.93.

${ }^{379}$ Idem, p. 100.

${ }^{380}$ Idem, pp.110-111.

${ }^{381}$ Tal oração lembra, em muitos aspectos, o Hino a Zeus de Cleantes (SVF, I, 537).

${ }^{382}$ Philosophie Morale des Stö̈ques, op.cit., pp.112 e 113.
} 
Vair que analisaremos, o De la constance, ${ }^{383}$ tem como modelo o De Constantia de Lípsio; além disso, vale lembrar que ambos os textos, como notamos logo nos títulos, recorrem ao modelo senequiano do De Constantia Sapientis. Segundo Jacqueline Lagrée, o contexto político no qual se insere o tratado de Du Vair é tão trágico e conturbado quanto aquele em que se publicou a obra de Lípsio. O De la constance veio a público em meio a

guerres de Religion, guerres de la Ligue, siège de Paris donnant lieu à une pauvreté et une famine telle qu'elle provoque des actes d'antropophagie; ce sont bien les «misères de Paris » qui suscitent l'écriture d'un livre qui copie le plan, la mise en scène (des amis qui se retrouvent dans un jardin), la thématique et jusqu'à de nombreuses phrases du modèle lipsien. ${ }^{384}$

Como bem resume Denise Carabin, o De la constance é composto por três livros, cada um dando a palavra a um personagem diferente, respectivamente: Musée, Orphée e Linus. A primeira parte é uma crítica ao chagrin e um elogio à constância; a segunda parte trata da Providência e do Destino, retomando, em grande medida, Lípsio; e na terceira, discorre-se sobre as razões para se ficar em Paris durante o siège e também acerca da imortalidade da alma. ${ }^{385}$

Destacaremos apenas alguns aspectos do tratado: aqueles que nos parecem mais interessantes para nosso trabalho. O caráter consolatório do diálogo fica explícito desde o início, em que Musée diz que a filosofia tem a capacidade de consolar as pessoas diante das desgraças. Porém, Du Vair (personagem) nega a consolação que a filosofia poderia proporcionar, em especial aquela filosofia que proíbe as lágrimas perante a dor (obviamente, a dos estóicos). ${ }^{386}$ Eis sua crítica explícita à doutrina estóica: “J'ay tenu toute ma vie pour la nature contre vostre philosophie: pource qu'il me sẽbloit que vous la faisiez trop puissãnte, \& luy vouliez attribuer vn commandemẽt trop violent

\footnotetext{
${ }^{383}$ De la constance et consolation és calamitez publiques. Paris: par Mamert Parisson, Impremeur du Roy. Chez Rob. Estienne, 1594.

${ }^{384}$ Lagrée, J. "La vertu stoïcienne de constance". In: Le stö̈cisme au XVI et au XVII siècle, op.cit., p.106.

${ }^{385}$ Les idées stoïciennes dans la littérature morale des XVI et XVII siècles (1575-1642), op.cit., pp.382383.

386 “J” estois desja offensé de vostre importune \& austere philosophie, qui defend les larmes à la douleur" (De la constance et consolation és calamitez publiques, op.cit., pp.4-5).
} 
\& tyrannique". ${ }^{387}$ Enquanto transcorre essa conversa, chegam Orfée e Linus e, enfim, Musée fica encarregado de consolar os ouvintes da tristeza que todos recebem "de ceste misere \& afflictiõ publique". ${ }^{388}$ Assim, Musée explica, com argumentos estóicos, qual a origem do mal: a perturbação e inquietude provêm de um julgamento (jugement) corrompido ou enganado. Os sentidos são como uma cera mole, sobre a qual se imprime, não a verdadeira e interior natureza, mas somente a face e forma exterior das coisas. "De tout cela se forme en notre ame ceste incosideree opinion que nous prenons des choses, qu'elles sont bõnes ou mauuaises, vtiles ou dommageables à suiure ou à fuïr : qui est certainement vne dangeurese guide, \& temeraire maistresse". ${ }^{389}$ Justamente a parir dessa "opinião", que toma conta de nossa imaginação em detrimento da droite raison, é que são engendradas as paixões, sendo que a tristesse é uma das mais perigosas inimigas do nosso repos. A tristeza “n'est autre chose qu'vne langueur d'esprit, \& decouragemẽt engendré par l'opinion que nous auons, que nous sommes affligez de grands maux". ${ }^{390}$ Outra paixão mencionada é a crainte, o maior e o mais pernicioso dos males. Esse medo ou temor "est de ce qui est, de ce qui n'est pas, de ce que par auenture ne sera pas, voire quelques fois de ce qui ne peut estre". ${ }^{391}$ Contra ele, são remédios a paciência e a prudência, assim como a esperança: "Il faut dire des fortunes des villes \& des Royaumes, ce qu'on dit ordinairement des maladies des hommes: Tãt qu'il y a vie, il y a esperãce : L'esperance demeure au corps aussi lõg temps que l'esprit".392

Os males que mais nos afligem e nos atemorizam são o banimento, a pobreza, a perda de honras, a perda dos filhos, a perda dos amigos e a perda de nossa prórpia vida. Contra o temor do banimento, devemos nos lembrar (mais uma vez) que o céu é a verdadeira e comum pátria dos homens, de onde eles vieram e para onde deverão retornar. Quanto à pobreza, jamais a natureza permitirá a carência absoluta, pois somos, de tal forma, naturalmente constituídos que são necessárias poucas coisas para nossa subsistência. Mais ainda: a pobreza é mais útil do que as riquezas para alcançarmos o soberano bem: o repos de l'ame e a tranquillité de l'esprit. Se é possível resistir à pobreza, muito mais fácil é suportar a perda das dignidades e honras. Em relação à perda de amigos, pais, filhos e de nossa própria vida é preciso lembrar sempre que as

\footnotetext{
${ }^{387}$ Idem, p.6.

${ }^{388}$ Idem, 10.

${ }^{389}$ Idem, p. 14.

${ }^{390}$ Idem, p. 15 .

${ }^{391}$ Idem, p. 19.

${ }^{392}$ Idem, p. 22.
} 
pessoas são mortais e deverão morrer um dia, pois ninguém escapa da morte, ${ }^{393}$ ou melhor, "le vray vsage de la mort, c'est de mettre fin à nos miseres". 394

Qualquer mal pode ser suplantado pela razão e pelo discurso. Mais ainda: através do discurso e da razão, a dor pode se tornar doce e agradável. Inclusive a morte é perfeitamente razoável:

Nous nous trompons, la mort n'a rien de soy d'effroyable, non plus que la naissance: la nature n'a rien d'estrange, ny de redoutable. La mort est tous les jours parmi nous, \& ne nous fait point de peur : nous mourons tous les jours, \& chaque heure de nostre vie qui est passee est morte pour nous. $^{395}$

Percebe-se ecoar nesse trecho o conhecido cotidie morimur de Sêneca, ${ }^{396}$ isto é, a idéia de que "el hombre no encuentra por primera vez a la Muerte cuando muere, sino que, desde que nace, se ve conjurado por la Muerte: el mismo vivir es un incessante morir, una muerte inexorable". 397

Não devemos temer a morte também porque no mundo tudo está em eterna mudança, não há nada de constante ou permanente ici-bas; muito pelo contrário, é necessário que tudo pereça. Por isso, temos que "supporter patiemmẽt, comme nous faisons les vicissitudes des saisons, alterations des elemens, \& autres changements que

\footnotetext{
${ }^{393} \mathrm{Na}$ doutrina estóica, um dos temas preferidos e mais recorrentes é a morte. Porém, concordamos com Blüher quando afirma que "los pensamientos de Séneca pertenecen a los más profundos e impresionantes que sobre el eterno tema de la muerte nos ha dejado la Edad Antigua" (Séneca en España, op.cit., p.179). Voltaremos a abordar a questão diversas vezes, mas, por enquanto, recordemos que Sêneca já havia feito um elogio à morte, dentre vários outros em diferentes obras, na Consolatio ad Marciam (XX, 1 e ss.).

${ }^{394}$ De la constance, op.cit., p.32.

${ }^{395}$ Idem, p.40.

${ }^{396}$ Para ilustrar, citemos dois trechos de Sêneca, sugeridos por Blüher, que tratam do tema: "Quem mihi dabis qui aliquod pretium tempori ponat, qui diem aestimet, qui intellegat se cotidie mori? In hoc enim fallimur, quod mortem prospicimus: magna pars eius iam praeterit. Quidquid aetatis retro est mors tenet. Fac ergo, mi Lucili, quod facere te scribis, omnes horas complectere; sic fiet ut minus ex crastino pendeas, si hodierno manum inieceris. Dum differtur vita transcurrit. Omnia, Lucili, aliena sunt, tempus tantum nostrum est" (Ep. ad Luc., I, 2-3); e "Cotidie morimur; cotidie enim demitur aliqua pars uitae, et tunc quoque cum crescimus uita decrescit. Infantiam amisimus, deinde pueritiam, deinde adulescentiam. Vsque ad hesternum quidquid transit temporis periit; hunc ipsum quem agimus diem cum morte diuidimus. Quemadmodum clepsydram non extremum stilicidium exhaurit sed quidquid ante defluxit, sic ultima hora qua esse desinimus non sola mortem facit sed sola consummat; tunc ad illam peruenimus, sed diu uenimus" (Idem, XXIV, 20).

${ }^{397}$ Blüher, K. A. Séneca en España, op.cit., p.180.
} 
nous voyõs tous les jours en toutes les parties du monde", 398 pois mesmo os grandes "acidentes" nos acometem devido à "providência eterna". 399

E é justamente pela Providência que Orphée dá início à discussão do livro II. Embora as noções de Providência e Destino tenham uma certa importância (não comparável, no entanto, aos assuntos da ética estóica) para nossa posterior análise do narrador da Constante Florinda, não nos deteremos nas questões apresentadas neste tratado de Du Vair, uma vez que as considerações que faríamos sobre o De la constance seriam praticamente as mesmas já feitas com relação aos textos de Lípsio. Destaquemos apenas que, no diálogo de Du Vair, é mais uma vez afirmado que tudo que acontece está ordenado pela puissance eternelle. Esse poder, ao governar o mundo, é a Providência: "le soin perpetuel, que Dieu a au gouuernement de tout ce qu'il a creé". ${ }^{400}$ Enquanto que o Destino é uma autre puissance que junta as coisas particulares e amarra várias causas diferentes, “\& ce par la force d'vne autre loy qu'elle semble auoir prescrit à tout les euenemens du monde, ayant disposé du temps \& de la façon, dont ils doiuent aduenir". 401

No terceiro e último livro, no qual Linus toma a palavra, as questões discutidas têm pouca relevância para nosso trabalho, a não ser a conclusão cristã da obra. A vida, numa perspectiva estóica totalmente cristianizada, é entendida como um aprendizado de nossas almas; ${ }^{402}$ somente depois da morte é que nos depararemos com a verdadeira felicidade: é a "mort, non mort, puis que c'est le commencemẽt de la vraye vie". ${ }^{403}$ Em suma, o que dá mais coragem aos cristãos para enfrentar, pacientemente, as misérias e aflições da vida é saber que, depois da morte, a alma sobreviverá e gozará, eternamente, da recompensa divina. ${ }^{404}$

Como explica Jacqueline Lagrée, “on a souvent tendance, dans les présentations du renouveau du stoïcisme au tournant du XVII ${ }^{\mathrm{e}}$ siècle, à centrer l'exposé sur trois noms: ceux de Juste Lipse, de Guillaume du Vair (...) et Pierre Charron" 405 Denise Carabin também ressalta que, tradicionalmente, consideram-se esses três nomes

\footnotetext{
${ }^{398}$ De la constance, op.cit., p.58.

${ }^{399}$ Idem, p.63.

${ }^{400}$ Idem, 67.

${ }^{401}$ Idem, p.73.

402 Não há como deixar de lembrar do famoso trecho de Sêneca: "uiuere tota uita discendum est et, quod magis fortasse miraberis, tota uita discendum est mori” (De Breuitate Vitae, VII, 3-4).

403 Idem, p. 167.

${ }^{404}$ Idem, p. 170.

${ }^{405}$ Juste Lipse et la Restauration du Stö̈cisme, op.cit., p.20.
} 
como "fundadores" do "neo-estoicismo". 406 Porém, as duas autoras já apresentam críticas a esse trivium, destacando o papel central de Lípsio e diminuindo a relevância de Charron na divulgação da doutrina estóica. E elas têm razão: o De la sagesse (Bordeaux, 1601) é um tratado bastante eclético, no qual não se percebe nenhuma predileção pela filosofia da Stoa, embora se notem algumas afinidades e críticas; muito semelhante ao que ocorre nos Essais de Montaigne. Por outro lado, esse emaranhado de doutrinas na obra de Charron é algo bastante comum no século XVII, muito mais comum do que qualquer sistematização filosófica que se queira imputar, anacronicamente, ao período. E, por isso mesmo, vale a pena tecer alguns comentários sobre esse importante tratado seiscentista, visando a demonstrar que, quando se fala de filosofia moral em fins do século XVI e começo do XVII, quase sempre se ouvem os ecos estóicos, ainda que dispersos entre vozes distintas.

O De la sagesse en $^{407}$ composto por três livros: o primeiro refere-se ao conhecimento de si e da condição humana; o segundo contém as instruções e regras gerais da Sagesse; e, no terceiro, são discutidas as quatro virtudes morais e são dados conselhos particulares de Sagesse.

Nas considerações de Charron sobre as passions et affections, é nítido o diálogo com a doutrina estóica, talvez por ter como principal modelo os "petits livrets moraux" de Du Vair, como o próprio Charron confessa. ${ }^{408}$ Isso fica claro, por exemplo, na definição da paixão como "un mouvement violent de l'ame en sa partie sensitive, lequel se fait ou pour, suyvre ce que l'ame pense luy estre bon, ou pour fuir ce qu'elle pense luy estre mauvais". 409 E prosseguem as semelhanças: o entendimento é o soberano que deve reinar absoluto na alma; os sentidos e o julgamento falso e indiferente do "vulgo" podem perturbar e corromper essa puissance do entendimento, formando na alma uma “inconsiderée opinion, que nous prenons des choses, qu'elles sont bonnes ou mauvaises, utiles ou dommageables, à suyvre ou fuyr: qui est certainement une tresdangereuse guide, et temeraire maistresse". ${ }^{410}$ A partir dessa conceituação com nítidos contatos com a ética estóica, principalmente pela intermediação de Du Vair, Charron começa a discorrer, detalhadamente, sobre as

\footnotetext{
${ }^{406}$ Les idées stoïciennes dans la littérature morale des XVI et XVII siècles (1575-1642), op.cit., p. 14.

${ }^{407}$ Charron, P. De la sagesse. Texte revu par Bárbara de Negroni. Paris: Fayard, 1986.

408 "Et n'ay point veu qui les despeigne plus naïvement et richement que le sieur du Vair en ces petits livrets moraux, dequels je me suis fort servy en ceste matiere passionée" (Idem, p.153).

${ }^{409}$ Idem, p. 155 .

${ }^{410}$ Idem, p. 157.
} 
paixões em particular. São muito interessantes as suas definições e descrições, mas não nos cabe aqui expô-las.

No último capítulo do livro II do De la sagesse, é notório o modelo senequiano do De tranquilitate animi, seja direto ou indireto, logo no título do capítulo, "Se maintenir em vraye tranquillité d'esprit le fruit et la couronne de sagesse et conclusion de ce livre", ou, ainda, quando se afirma que o soberano bem do homem é a tranqüilidade do espírito (esprit), que não consiste em se retirar dos affaires, pois é uma tranqüilidade que nada pode perturbar. ${ }^{411}$

Para encerrar, merecem pelo menos serem mencionadas as definições de Charron, no livro III, das quatro virtudes morais. A prudence é a rainha de todas as outras virtudes e é "la connoissance et le chois des choses, qu'il faut desirer ou fuyr; c'est la juste estimation et le triage des choses ; c'est l'oeil qui tout voit, qui tout conduit et ordonne". Ela consiste em se fazer bem três coisas: consultar e deliberar, julgar e resolver, conduzir e executar. ${ }^{412} \mathrm{~A}$ " justice est rendre à chascun ce qui luy appartient, à soy premierement et puis à autruy". ${ }^{413}$ Enfim, interessante para os objetivos do nosso estudo é o que se diz sobre a force e a temperance, que, segundo o autor, se resumem à constância, "qui est une droitte et equable fermeté d'ame, pour toutes sortes d'accidens et choses externes", a qual não permite que o homem se exalte na prosperidade (temperança) nem se curve na adversidade (força) ${ }^{414}$ algo que o nosso narrador exigirá, constantemente, de Florinda e Arnaldo.

Muito mais explícita é a presença da doutrina estóica nos escritos de Francisco de Quevedo. ${ }^{415}$ Em vários de seus textos (tanto em sua prosa como em sua poesia) os ecos estóicos são evidentes, mas, para este trabalho, nos restringiremos à análise de três obras: De los remedios de cualquier fortuna (terminada em 1633, não foi publicada antes de 1638), Nombre, origen, intento, recomendación y descendencia de la doctrina estoica (1634) e La cuna y la sepultura: para el conocimiento proprio y desengaño de las cosas ajenas (pela dedicatória, sabe-se que esse escrito data de 1633; porém, sua primeira edição é de 1634).

\footnotetext{
${ }^{411}$ Idem, p.539.

412 Idem, p.545.

${ }^{413}$ Idem, p.625.

414 Idem, p.725.

415 Sobre o "estoicismo" em Quevedo, há o livro de H. Ettinghausen, Francisco de Quevedo and the Neostoic Movement (Oxford: Oxford University Press, 1972). Veja-se, também, K. A. Blüher, Séneca en España, op.cit., pp.427-486; e H. Méchoulan, “Quevedo stoïcien?”, in: Le stö̈cisme au XVI et au XVII siècle, op.cit., pp.189-203.
} 
O De los remedios de cualquier fortuna ${ }^{416}$ é uma tradução, à qual são adicionados comentários de Quevedo, do texto apócrifo de Sêneca: De remediis fortuitorum. Na sua edição da Opera Omnia de Sêneca, Erasmo incluiu esse escrito entre os "autênticos" do filósofo cordovês; já Lípsio, negou a dita autoria devido a questões estilísticas. Quevedo se opôs a Lípsio e entendeu ser o De remediis fortuitorum uma obra autêntica de Sêneca, tanto que na sua tradução tomou como texto base aquele da edição de Erasmo. ${ }^{417}$

No De los remedios de cualquier fortuna, a cada "desdicha" citada (ao todo, são 17), seguem-se os supostos comentários consolatórios de Sêneca e depois os de Quevedo. As "desdichas” são as seguintes (vale a pena mencioná-las, para se ter uma noção do teor estóico da obra): "morirás"; "serás degollado"; "morirás lejos"; "morirás mozo"; "carecerás de sepultura"; "estoy enfermo"; "mal juzgan de ti los hombres"; "serás desterrado"; "padezco dolor"; "aflígeme la pobreza”; "no soy poderoso"; "perdi el dinero"; "perdi los ojos"; "perdi los hijos"; "caí en manos de ladrones"; "perdi el amigo"; e "perdi buena mujer". 418

Destaquemos, pois, alguns comentários (tanto os traduzidos como os do próprio Quevedo). Como percebemos, as cinco primeiras “desdichas” tratam da morte. Eis por que não deveríamos temê-la: a vida é uma peregrinação, quando já se caminhou muito, é necessário voltar; o homem é um "animal racional mortal" que precisa descansar; portanto, como diz Quevedo, deve-se morrer "con el proprio contento que quien navega llega al puerto, y quien peregrina, a su patria". ${ }^{419}$ Se há de se morrer longe de casa, pouco importa, pois todo o mundo é a verdadeira "casa", ou melhor, "sólo muere lejos el que en su propria casa se persuade que está lejos su muerte", ${ }^{420}$

Quanto às doenças, também não precisamos nos preocupar: a enfermidade não durará para sempre, pois ou ela nos vencerá ou nós a venceremos. Além disso, estamos todos doentes desde o pecado original, como afirma Quevedo: "Después que el pecado enfermó la naturaleza, mi propria naturaleza es enferma, y yo soy una enfermedad viva". ${ }^{421}$ Com a mesma paciência cristã, devemos enfrentar a perda dos filhos: quem nos deu eles, está, simplemente, levando-os de volta. Por isso, consola-nos Quevedo:

\footnotetext{
${ }^{416}$ Obras completas. Tomo I, op.cit., pp.1066-1083.

${ }^{417}$ V. Blüher, Séneca en España, op.cit., pp.456-457.

${ }^{418}$ Obras completas, op.cit., p.1069.

${ }^{419}$ Idem, p. 1070.

${ }^{420}$ Idem, p. 1071 .

${ }^{421}$ Idem, p. 1074.
} 
"los hijos que perdiste cuando murieron, hallarás cuando te mueras. Según esto, no digas que los pierdes, sino que los sigues". 422

Com relação ao De los remedios de cualquier fortuna, isso basta para que fiquem evidentes as características estóicas do texto. Porém, é na Doctrina Estoica ${ }^{423}$ que Quevedo tentará fazer uma síntese, à semelhança daquela feita por Lípsio em sua Manuductio, da ética dos estóicos, em especial do Encheiridon de Epicteto. Conforme Blüher, na Doctrina Estoica percebe-se o interesse de Quevedo em "derivar el origen de la filosofia estoica de los libros del Antiguo Testamento con el fin de fundir, más íntimamente que antes, Stoa y Cristianismo". 424

Refirindo-se ao "nome" da doutrina que "nos dió en arte fácil y provechosa Epicteto", Quevedo lembra que a nomeação de seus filósofos deriva de "Pórtico" $($ Stoa $),{ }^{425}$ como vimos em Diógenes Laércio. Porém, a verdadeira origem dos estóicos seria mais antiga que o nome e diferente e mais nobre do que muitos acharam, pois a secta estóica é a que mais buscou a virtude e que mais se aproximou da valentía cristiana, se não pecasse no excesso de insensibilidad (a velha crítica à apatheia). Para Quevedo, as verdades estóicas "se derivan del libro sagrado de Job, trasladadas en precepto de sus acciones y palabras literalmente". 426

Baseando-se claramente no Encheiridon, Quevedo resume a doutrina estóica nos seguintes princípios: as coisas se dividem em próprias e alheias; as próprias estão em nossas mãos, as alheias em mãos alheias; aquelas nos interessam, estas não nos pertencem e, por isso, não devem nos perturbar nem nos afligir; não temos que procurar nas coisas que aconteçam conforme o nosso desejo, mas ajustar o nosso desejo com os "sucessos" das coisas; assim teremos liberdade, paz e sossego, do contrário, sempre andaremos queixosos e perturbados; não devemos dizer que perdemos os filhos e as propriedades, mas que pagamos a quem emprestou; e, por fim, o sábio não pode culpar a outro ou a si mesmo por aquilo que acontece, nem se queixar de Deus. ${ }^{427}$ A partir desse resumo, segundo Quevedo, é evidente a semelhança entre o Livro de Jó e a filosofia estóica: "El capítulo XIII de nuestro Manual (o Encheiridon) confiesa es discípulo, no sólo en el precepto, sino en las palabras proprias deste sagrado libro (o

\footnotetext{
${ }^{422}$ Idem, p. 1081.

${ }^{423}$ Idem, pp.1084-1093.

${ }^{424}$ Séneca en España, op.cit., p.462.

425 Obras completas, op.cit., p.1084.

${ }^{426}$ Idem, p. 1085.

${ }^{427}$ Idem, pp.1085-1086.
} 
Livro de Jó)". ${ }^{428}$ Quanto à origem cronológica, o autor lembra que tudo começou com Zenon, que "limpou" a doutrina dos cínicos. Aproveitando-se, possivelmente, dos dados sobre a nacionalidade cipriota de Zenon que Lípsio havia reunido (Manuductio ad Stoicam Philosophiam, I, 10), Quevedo explorou-os no sentido de comprovar que o "fundador" da Stoa tinha conhecido diretamente os escritos do Antigo Testamento, particularmente o Livro de Jó. ${ }^{429}$

Se essa é a origem, eis o "intento" da doutrina estóica: despezar todas as coisas que estão em poder alheio, e isso sem desprezar as pessoas com desalinho e vileza; seguir a virtude; colocar o espírito além das perturbações; colocar o homem acima das adversidades, já que não pode estar fora, justamente por ser homem; estabelecer a paz da alma pela insensibilidad; viver com o corpo, mas não para o corpo; "contar por vida la buena, no la larga; no por muchos años, sino por inculpables"; não desprezar a morte, porque é o último bem da natureza, mas não temê-la também, porque é descanso e forçosa. ${ }^{430}$

Porém, o "escândalo" da seita estóica está em seus paradoxos. Vejamos os dois que mais chamam a atenção e suscitam críticas de Quevedo. Primeiro, o suicídio: "Puede el sábio darse la muerte; esle decente y debe hacerlo". ${ }^{431}$ Para demonstrar a aprovação estóica do sucídio, cita a epístola LXIX e o De Ira III, XV, de Sêneca. Mas, com base em Epicteto, condena o filósofo cordovês e prova que nem todos os estóicos eram a favor do suicídio, expondo "la fealdad deste error" ${ }^{432}$ Segundo, a apatheia: "el instituto desta secta fué la apatía o insensibilidad, excluyendo totalmente el padecer afectos: esta totalidad la condenaron los pitagóricos y los peripateticos". 433 Sobre o assunto, menciona os testemunhos de Lactâncio, São Jerônimo e da Manuductio de Lípsio, apontando os erros das colocações desse último. São Tomás, e praticamente todos “doutores angélicos", condenaram, catolicamente, a apatia, e Quevedo tenta

\footnotetext{
${ }^{428}$ Idem, p. 1087.

429 "Colígese de todos los autores citados, que los cínicos y Zénon, que fué su discípulo y el capitán de los cinicos limpios y aliñados que se llamaron estoicos, se precian de ser naturales de las tierras confines con Judea, de donde derivó la sabiduría a todas las naciones; por lo que no sólo es posible, sino fácil, antes forzoso el haber los cínicos y los estoicos visto los libros sagrados, siendo mezclados por la habitación con los hebreos, que nunca los dejaban de la mano. Lo que se colige destas autoridades, y se prueba con la demonstración que he hecho de su doctrina, y del texto del libro de Job” (Idem, pp.1087-1088).

${ }^{430}$ Idem, p. 1088 .

${ }^{431}$ Idem, p. 1088 .

432 Idem, p. 1089.

${ }^{433}$ Idem, p. 1091.
} 
defender os estóicos: "Ellos dicen que no se han de sentir algunos afectos, y esto enseñan y esto mandan". 434

Quanto à "recomendação" da seita estóica pode ser sintetizada nas palavras de Blüher: "En virtud del aserto de que la Stoa se derivaba del Antiguo Testamento, la doctrina estoica em esta obra de Quevedo se presenta como filosofía casi enteramente aceptable para un cristiano". ${ }^{435}$

Por fim, na descendência e genealogia da doutrina, Quevedo aponta entre os estóicos antigos gregos (ou que, pelo menos, tenham demonstrado alguma afinidade com a filosofia da Stoa), além dos nomes mais comumente citados, outros surpreendentes, como Homero, Sócrates, Sófocles, Demóstenes e Platão; entre os romanos, além dos nomes mencionados por Sexto Empírico, afirma que Virgílio seguiu a apatheia estóica; entre os cristãos, refere aqueles que mais teriam se afeiçoado aos estóicos: Tertuliano, Panteno, Clemente de Alexandria, São Jerônimo, São Carlos Borromeu, Francisco de Sales, Justo Lípsio e Francisco Sánchez de las Brozas. Sobre seu próprio caráter estóico, eis o julgamento final de Quevedo:

Yo no tengo suficiencia de estoico, mas tengo afición a los estoicos. Hame asistido su doctrina por guía en las dudas, por consuelo en los trabajos, por defensa en las persecuciones, que tanta parte han poseído de mi vida.

Yo he tenido su dotrina por estudio continuo; no sé si ella ha tenido en mí buen estudiante. ${ }^{436}$

Por fim, em La cuna y la sepultura ${ }^{437}$ também há alguns traços estóicos que merecem ser salientados. Vale ressaltar que esse texto é uma ampliação da Doctrina moral del conocimiento proprio y desengaño de las cosas ajenas (a primeira edição apareceu em 1630 em Saragoça, mas é certo que a obra é anterior a 12 de novembro de 1612) ${ }^{438}$ La cuna y la sepultura é composta por cinco capítulos. Neste, em relação aos dois outros textos que analisamos, são poucos os momentos em que se percebe um diálogo evidente com a doutrina estóica.

\footnotetext{
${ }^{434}$ Idem, p. 1092.

${ }^{435}$ Séneca en España, op.cit., p.467.

${ }^{436}$ Obras completas, op.cit., p.1093.

${ }^{437}$ Idem, pp. 1324-1352.

${ }^{438}$ Para mais detalhes e uma análise cuidadosa do texto da Doctrina Moral, veja-se K. A. Blüher, Séneca en España, op.cit., pp.427-447.
} 
No trecho que encerra o capítulo I, há uma clara cristianização do cotidie morimur senequiano e da distinção de Epicteto entre as coisas próprias e as alheias, demonstrando, assim, que o único cuidado que devemos ter é com a alma (própria e imortal) e não com o corpo (alheio e perecível):

\begin{abstract}
Empieza, pues, hombre, con esto conocimiento, y ten de ti firmimente tales opiniones: que naciste para morir y que vives muriendo; que traes el alma enterrada en el cuerpo, que cuando muere, en cierta forma resucita; que tu negocio es el logro de tu alma; que el cuerpo sirve a esa vida prestada que gastas; que es tan frágil como ves, tan perecedero como parece y que es más feo que parece, y que en breve tiempo lo estará más; que tu cuidado es tu alma, y que solas sus cosas son tuyas, y las demás ajenas; que no debes trabajar en otras, sino en ésas, por estar a tu cargo; que has de dar cuenta dellas al que te las dio y que se las agradeces sólo con dársela buena; y que el premio o el castigo se te aguarda a ti; y que pues será forzoso morir para ti, y a tu riesgo, es razón que vivas para ti, y a tu provecho. ${ }^{439}$
\end{abstract}

No capítulo II, vituperando as honras, ofícios e dignidades que as pessoas tanto cobiçam, Quevedo parece recorrer à reprovação estóica das paixões para aconselhar que a vontade não deve estar acompanhada dos "apetitos y deseos, que son apasionados". ${ }^{440}$ Além disso, numa frase modelar, retoma o antigo tópico estóico (por exemplo, De Prouidentia, II, 9 e III, 4; De Constantia Sapientis, III, 3) de que o sábio tem que vencer a fortuna, e não ser por ela vencido: "No es dichoso aquel a quien la fortuna no puede dar nada más, sino aquel a quien la fortuna no puede quitar nada". ${ }^{441}$

Num nítido diálogo com o De Ira de Sêneca, Quevedo, no capítulo III, define a ira como "una breve locura y repentina, un olvido de la razón, y si dura, un desprecio della, un afecto rebelde al entendimiento y un motín de la sangre y una soberbia inconsiderada". Os "sentimentos", tais como a tristeza e a ira, não são próprios da natureza. $^{442}$

No IV capítulo, os preceitos estóicos são pouco perceptíveis, talvez por quererse afirmar a superioridade da doutrina cristã, como se nota na definição da verdadeira

\footnotetext{
${ }^{439}$ Obras completas, op.cit., p.1330.

440 Idem, p.1334.

441 Idem, p. 1336.

${ }^{442}$ Idem, p. 1342.
} 
sabedoria: "la sabiduría verdadera está en la verdad, y la verdad es una sola, y esa verdad una es Dios solo, que por eso le llaman Dios verdadero; y fuera dél, todo es opinión y los más cuerdos sospechan". ${ }^{44}$ Isso fica ainda mais evidente no último capítulo, absolutamente cristão, como se verifica logo no título: "Perfectiona los cuatros capítulos precedentes de la filosofía estoica con la verdad cristiana, acompañándolos con tres oraciones a Jesucristo nuestro Señor". 444

Outro autor do século XVII que também discute, em alguns de seus escritos, idéias da doutrina estóica é D. Francisco Manuel de Melo, cuja ascendência de Quevedo é bastante conhecida. ${ }^{445}$ Segismundo Spina $^{446}$ e Maria Lucília Gonçalves Pires ${ }^{447}$ já indicaram a presença marcante da filosofia dos estóicos (em particular, de Sêneca) nas obras de D. Francisco Manuel e, mais do que isso, a necessidade de estudos, ainda inexistentes, que tratem detidamente da questão. Porém, está fora das pretensões e possibilidades deste nosso trabalho fazer uma análise exaustiva. O que faremos é expor algumas discussões, que dialogam com a "seita estóica", presentes em dois textos do autor: El Fenis de Africa: Agustino Aurelio, Obispo Hypponense (1648-1649) e Vitoria del Hombre sobre el Combate de Virtudes y Vícios: Triunfo de la Filosofia Cristiana contra la Doctrina Estoyca (publicada, possivelmente, depois de março de 1650). ${ }^{448}$

Para começar, não podemos nos esquecer que em um de seus Apólogos Dialogais, ${ }^{449}$ o Hospital das Letras, além do próprio D. Francisco Manuel e de Trajano Boccalini, os outros dois personagens que participam do diálogo são justamente Lípsio e Quevedo. Além disso, na poesia do Melodino, também são retomados temas estóicos,

\footnotetext{
443 Idem, p. 1344.

${ }^{444}$ Idem, p. 1346.

445 Essa e outras questões são discutidas na conhecida biografia de D. Francisco Manuel de Melo: Prestage, E. D. Francisco Manuel de Mello: esboço biographico. Lisboa: Fenda, 1996.

446 "Sêneca foi uma presença constante na poesia do Melodino, como foi nos poetas, nos moralistas e dramaturgos da Europa do século XVII - especialmente na Península Ibérica.” Por isso, conclui Spina: "Urge, pois, que a influência de Sêneca na cultura portuguesa dos séculos XVI e XVII seja traçada, pois do contrário as tentativas da história geral da cultura lusa estão fadadas ao insucesso quando saímos do Renascimento" (A tuba de Calíope: quarta musa das Obras Métricas, op.cit., pp.32 e 34).

447 "Da presença da filosofia estóica em geral e senequista em particular na obra de D. Francisco Manuel de Melo nenhum autor, que eu saiba, se ocupou detidamente, se bem que a questão tenha sido por vezes apontada" ("O tema da «guerra interior» nas Obras Métricas de D. Francisco Manuel de Melo". In: Xadrez de Palavras: Estudos de Literatura Barroca, op.cit., p.64).

${ }^{448}$ Os dois textos se encontram no primeiro tomo das Obras Morales de Don Francisco Manuel a la Serenissima Catalina Reyna de la Gran Bretaña (En Roma: Por el Falco, 1664). Nossas citações serão feitas sempre com base nessa edição.

${ }^{449}$ Melo, D. F. M. Apólogos Dialogais. Prefácio e notas de José Pereira Tavares. Lisboa: Sá da Costa, 1959.
} 
em particular os que se encontram nos textos de Sêneca. ${ }^{450}$ Mas nosso estudo se focará apenas naqueles dois escritos doutrinários das Obras Morales de D. Francisco Manuel.

O próprio autor, na dedicatória à rainha Catarina, explica a divisão e os assuntos dos textos que constituem o primeiro tomo de suas Obras Morales. ${ }^{451}$ Eis por que estas são compostas por quatro partes:

De la Ciudad de Dios escriue en sus Visiones, el imperial Euangelista: Que ella era puesta en forma quadrangular; a cuya imitacion el Arte, y la Naturaleça se concordaron, dando semejante forma a todas fabricas que procuran hacer eternas. Por este proprio designio he yo traçado de quatro angulos este Libro mio.

Especificamente, quanto a El Fenis de Africa, que preenche o segundo e o terceiro “ângulos”, afirma D. Francisco Manuel:

Muestra el segundo Angulo deste Edifficio, aquella Primera Parte de la Vida Filosofica del Vnico Fenis de Africa San Agostín: mientras que como docto profesò la temporal Sabiduria con todas las obseruaciones, que pertenecen a vn Varon, profundamente Sabio. Offrece el Tercer Angulo la vltima porcion de sus anos: quando ya despreciados los Precetos de Filosofo, passò a las obseruaciones de Santo.

Logo na "acción I" dessa "vida" de Santo Agostinho, Sêneca é a primeira autoridade mencionada para assegurar o poder absoluto da Providência, que não precisa do aplauso humano, nem da nossa queixa ou elogio:

Poco nos cuesta a defender la Prouidencia, dixo el Seneca. Menos a obdecer, y a creer menos. Lo que está por cuenta de immensa Sabiduria, que puede deuerle al aplauso de la inorancia? Para assegurarnos de que es bien obrado, basta entenderse cuya es la obra.

\footnotetext{
${ }^{450}$ Ver os textos, já citados, de José Adriano de Carvalho, "A poesia sacra de D. Francisco Manuel de Melo", de Segismundo Spina, "Introdução" à Tuba de Calíope, e de Maria Lucília Gonçalves Pires, "O tema da «guerra interior» nas Obras Métricas de D. Francisco Manuel de Melo".

${ }^{451}$ Vale ressaltar que, além da Vitoria del Hombre e do El Fenis de Africa, esse primeiro tomo das Obras Morales contém ainda um outro escrito intitulado El Mayor Pequeno: Vida y Muerte del Serafin humano Francisco de Assis.
} 
Como a ninguna dá credito nuestra alabança, tan poco nuestra quexa es poderosa a hacer contigente la bondad de ninguna... ${ }^{452}$

No entanto, muito mais interessante do que as considerações sobre a Providência que encontramos em El Fenis de Africa, parece-nos a idéia da "interior batalha" entre a razão e as paixões, que leva à crítica da apatheia estóica. Maria Lucília Gonçalves Pires assim sintetiza a questão:

D. Francisco, dissertando sobre a «interior batalha» que se trava no homem entre a razão e as paixões, (Parte I, Livro I, Acção 26), refuta a doutrina estóica, contrapondo-lhe Platão e Aristóteles. Segundo o autor, estes filósofos consideram as paixões inseparáveis da natureza humana e afirmam ser a atitude do sábio, não aniquila-las, mas sim controlá-las. E a proposta estóica de inalterável tranquilidade espiritual suscita mesmo a D. Francisco um comentário um tanto céptico: «Esta fue siempre la más oída y menos vista filosofia de quantas el mundo ha profesado». ${ }^{453}$

Nessa apreciação da autora, nota-se um certo desconhecimento da recepção da filosofia estóica em fins do século XVI, sendo equivocado afirmar, simplesmente, que há uma rejeição da "doutrina estóica" porque se pretende moderar a apatheia; como vimos, é exatamente essa uma das principais características da doutrina estóico-cristã dos séculos XVI e XVII. E a citação que se faz do texto de D. Francisco ("Esta fue siempre la más oída y menos vista filosofia de quantas el mundo ha profesado"), avaliada como "um comentário um tanto céptico", nada mais é do que a reprodução de uma antiga e conhecida crítica à ética estóica, divulgada, pelo menos, desde Cícero e Tácito.

Desse modo, vale a pena nos determos um pouco na acción XXVI da primeira parte, livro I, d'El Fenis de Africa por ser um dos momentos da obra em que o diálogo crítico com a filosofia estóica se mostra mais evidente. Entretanto, isso não implica um “antiestoicismo" de D. Francisco Manuel, como supõem Maria Lucília Gonçalves Pires (como vimos no trecho acima citado) e Giacinto Manuppella (sendo que o foco das

452 El Fenis de Africa, Parte I, Livro I, Ação 1, pp. 2-3. José Adriano de Carvalho, para tratar da Providência na poesia de D. Francisco Manuel, recorre a alguns trechos d' El Fenis de África (Veja-se, por exemplo: "A poesia sacra de D. Francisco Manuel de Melo", op.cit., pp.383-384).

453 "O tema da «guerra interior» nas Obras Métricas de D. Francisco Manuel de Melo", op.cit., pp.66-67. 
análises de Manuppella é a Vitoria del Hombre, embora também faça comentários sobre El Fenis de Africa, como veremos mais adiante).

O assunto dessa acción XXVI é a "dura batalla" dos "effetos" e dos "affectos". Estes últimos são os "mouimientos, ó passiones, proprias del animo"; aqueles são "las execuciones del entendimiento"; e, por isso, seriam "cosas entre sy contrarias".454 Segundo D. Francisco Manuel, esse tema diz respeito à filosofia moral, e, entre os gregos, as commociones da alma foram divididas em duas partes: Pathi e Eupathi, sendo ambos os termos derivados de Pathia que, "en romance, es: Padecimiento". Já os latinos chamaram a essas mesmas "comoções": "Passiones, y Constancias". Para abordar a questão, o autor, como ele mesmo declara, fará uso das idéias das escolas platônica, peripatética e estóica. Porém, aos platônicos e peripatéticos, opunham-se os estóicos, que queriam saber: "si a los pechos de los sabios eran comunes los affectos, que a los demás hombres?" 455 Para Zenon e Crisipo, “cabeça dos estóicos”, a resposta seria negativa. Cícero é que teria tentado conciliar essas escolas explicando que a divergência não estava na coisa, mas apenas no nome: a ética estóica teria estreitado o conceito de Bem, identificando-o somente à virtude. E é dessa diversa conceituação que procedeu o "certamen de toda la filosofia: En, si era licito, ó ilícito al sabio, sentirse, ó no sentirse, con la perdida de los bienes; dando por este modo a entender los prosperos, ó aduersos casos, al sapiente sucedidos". ${ }^{456}$ Os peripatéticos almejam alguma sujeição dos affectos à sabedoria, mas nunca seu rendimiento completo, como querem os estóicos. Para estes filósofos, de acordo com o autor, o sábio é aquele que, por um hábito vitorioso, alcança o império sobre os "casos", que torna inalterável o ânimo do virtuoso. Em meio a discussões como essa é que surge a afirmação, como querem alguns, "antiestóica": "Esta fue la más oída, y menos vista, filosofia, de quantas el mundo ha profesado". Do outro lado, estão os platônicos e peripatéticos, para quem "el afligir con las aduersidades, es mayor indicio de sabiduria, y de bondad, que el despreciallas". 457

Para D. Francisco Manuel, tal disputa entre os "Éticos" (aqueles que tratam da filosofia moral) se resolve, sem contenda, entre os "Naturais" (aqueles que se dedicam à "Física", pensando-se na mencionada tripartição da filosofia): "porque aquella visiones del alma, que llaman fantasias, no està en nuestro albedrio que acontezcan, ó dexen de

\footnotetext{
${ }^{454}$ El Fenis de Africa, Parte I, Livro I, Ação 26, p.201.

${ }^{455}$ Idem ibidem, p. 202.

${ }^{456}$ Idem ibidem, p. 203.

${ }^{457}$ Idem ibidem, p. 204.
} 
acontecer al alma, horriblemente, quando vienen de cosas horribles, ó apaciblemente, quando de cosas apacibles proceden". ${ }^{458}$ Então, é necessário que essas paixões (as fantasias) perturbem ou alegrem, pois elas se antecipam às operações do juízo, que é quem divide a contenda de affectos e de effetos. Os fantasmas, como diz o autor, não causam por si, sem a intervenção do entendimento, a opinião de mal ou de bem; nem são reprovados ou aceitos antes de julgados. Embora não citada no texto, essa discussão remete a uma das idéias mais importantes e recorrentes em Epicteto, já referida por nós, que é a distinção entre aquilo que está sob nosso controle e aquilo que não está. O que o homem controla é apenas sua prohairesis, seu "propósito moral" ou sua capacidade de antecipação e escolha prévia, que o leva, ou deveria levar, a fazer um uso correto das phantasias. ${ }^{459}$ Já para D. Francisco Manuel, trata-se do juízo: "la potestad de la sabidoria; y es virtud la sentencia desta potestad, por la qual se diuede lo bueno, de lo malo". ${ }^{460} \mathrm{E}$, segundo os estóicos, seria essa a única diferença entre o ânimo do néscio e o do sábio: o ânimo do primeiro se rende às paixões, superando com os affectos aos effetos; enquanto que o do sábio, ainda que padeça, necessariamente, as paixões, guarda na sua vontade um estável conhecimento do que deve obrar, e dessa complacência nasce o vigor com que obra. Conclui, então, o autor: "Por esto, quiçá, dixeron los Estoycos: No tiene el sabio passiones; porque nunca le vieron a ellas rendido; no porque inorassen, no està en nuestra mano el escusar ser dellas combatido". 461

Como se nota, tais colocações de D. Francisco Manuel de Melo não indicam um ceticismo em relação à doutrina estóica, como supôs Maria Lucília Gonçalves Pires. Ao contrário, o debate que há nesse trecho d'El Fenis de Africa mostra como a "escola estóica" é uma das mais importantes fontes, para os autores do século XVII, quando o assunto abordado diz respeito à filosofia moral. Ao se discutir as paixões, por exemplo, os estóicos são auctoritates quase sempre imprescindíveis. As doutrinas antigas, seja a platônica, a peripatética ou a estóica, não podem ser simplesmente "refutadas" por esses autores quinhentistas e seiscentistas; elas fazem parte da própria constituição da "filosofia cristã", ${ }^{462}$ que é aquela que quase todos eles aprovam e defendem em seus escritos.

\footnotetext{
${ }^{458}$ Idem ibidem, p. 205.

${ }^{459}$ Ver, por exemplo, Diatribes, I, 1; e Encheiridon, 1.

${ }^{460}$ El Fenis de Africa, Parte I, Livro I, Ação 26, p.206.

${ }^{461}$ Idem ibidem, p. 206.

${ }^{462}$ Sobre essa questão, não nos esqueçamos do estudo de Werner Jaeger: Cristianismo primitivo e Paideia grega. Trad. Teresa Louro Perez. Lisboa: Edições 70, 2002.
} 
Nesse sentido é que se pode compreender melhor o outro texto de D. Francisco Manuel de Melo que nos propusemos a analisar: Vitoria del Hombre sobre el Combate de Virtudes y Vicios. O estudo mais detalhado da Vitoria del Hombre ainda é o de Giacinto Manuppella, “Acerca do Cosmopolitismo Intelectual de D. Francisco Manuel de Melo", embora o autor desconheça que a obra seja uma tradução (bastante "livre") de um tratado de Jean-François Senault: De l'usage des passions (1642). ${ }^{463}$ Logo na primeira frase de seu estudo, Manuppella afirma que "D. Francisco Manuel de Melo consignou a sua inequívoca profissão de fé antiestóica numa obra de largo fôlego", referindo-se justamente à Vitoria del Hombre. ${ }^{464}$ Falar-se assim, com tanta certeza, de um "antiestoicismo" no texto de D. Francisco Manuel, talvez se deixando levar pelo subtítulo "Triunfo de la Filosofia Cristiana contra la Doctrina Estoyca", por tudo o que discutimos até agora, parece-nos, no mínimo, precipitado. Como observamos nas análises anteriores, Quevedo também buscava o "triunfo" da filosofia cristã, mas nem por isso (longe disso, na verdade) é possível dizer que o espanhol era um "antiestóico".

É preciso, então, examinar com mais cuidado a presença da doutrina estóica na Vitoria del Hombre. Esse tratado moral, composto por onze livros, discute o uso das paixões: o homem deve dominar suas paixões com o auxílio da razão que, diferentemente do que defendiam os estóicos, não é auto-suficiente para exercer tal domínio, dependendo sempre da iluminação da graça divina. Outra divergência fundamental desse tratado com a doutrina estóica, além da necessidade da graça, é a valorização das paixões: estas não devem ser extirpadas ou extintas, como queriam os filósofos da Stoa, mas controladas ou moderadas e reutilizadas pelos homens, pois toda paixão, com ajuda da razão e da graça, pode ser transformada em virtude. É o que apreendemos, por exemplo, deste trecho da "Introdução" da obra:

\footnotetext{
porque supuesto, que nuestras Passiones, sean desordenadas, y que el Pecado, las reduxesse a un punto, donde se halla más cierta la culpa, que la inocencia; todauia estamos ciertos, que la Raçon, con la Gracia, las pueden emplear con utilidad; de tal suerte, que sin lisonja, me atreuo a decir, que no ay Passion humana tan indomita que no se pueda trocar en vna Virtud gloriosissima. ${ }^{465}$
}

\footnotetext{
${ }^{463}$ De l'usage des passions. Texte revu par Christiane Frémont. Paris : Fayard, 1987.

464 "Acerca do Cosmopolitismo Intelectual de D. Francisco Manuel de Melo", op.cit., p.59.

${ }^{465}$ Vitoroia del Hombre, Livro I, "Introdución”, p.3.
} 
O primeiro capítulo do livro I intitula-se "Defensa de las Passiones, contra la Doctrina Estoyca", em consonância com o subtítulo, já mencionado, da obra. Nesse capítulo, afirma-se que os estóicos erraram por soberbia ao tentarem "afogar" as paixões. A doutrina estóica das paixões é assim resumida: "Que ser vno esclabo de sus Passiones, es viuir en tyrania, y que es fuerça renunciar la liuertad, para obedecer insolentes domínios". ${ }^{466}$ Porém, mesmo Sêneca ("que consideramos, como el mayor eloqüente, el más soberbio, discípulo, desta Escuela altiua") teria admitido que o sábio também sentia, algumas vezes, movimentos internos e perturbados, e ainda que não padecesse verdadeiras paixões, experimentava suas sombras e aparências. Nessa discussão é que se encaixa uma crítca bastante comum, em paritcular entre os autores dos séculos XVI e XVII, à filosofia da Stoa: se "los Estoycos tenian más altiuos dictamenes, no tenian por esto, más altos sentimientos. No culpauan ellos las Passiones todas, pero solamente su exercicio con ingeniosa cautela; pues sy alcançaron deseos de reprimillas, nunca conseguieron la esperança del vencellas". 467 Em suma: os ditames estóicos estão muito além daquilo que um homem pode alcançar em suas ações. Por isso, é preciso saber usar as paixões, tornando-as virtudes, em vez de almejar em vão eliminá-las, já que elas são essencialmente humanas, intrasponíveis para um ser que não é constituído somente pela pureza da alma, mas também pelo pecado da carne. E os únicos soldados capazes de dominar as paixões, para que, moderadas, sejam utilizadas corretamente, são a razão e a graça, que devem agir em conjunto nessa "batalha interior".

No capítulo seguinte do livro I, define-se a paixão: "No es, en fin, la Passion outra cosa que vn Mouimiento del Apetito Sensitiuo, causado por la imaginacion de vn Bien, ó de vn Mal aparente, ó verdadero, que muda el cuerpo contra las leyes de la quietud natural". ${ }^{468}$ Essa definição, como as outras que vimos dos divulgadores da doutrina estóica nos séculos XVI e XVII, ecoa aquelas atribuídas aos estóicos, desde Cícero e Diógenes Laércio; mas não podemos deixar de reconhecer nela também uma evidente dependência das noções de psyché (e de suas divisões ou partes) que encontramos em Platão e em Aristóteles, em particular no De Anima deste último filósofo. Definidas assim as paixões no texto de D. Francisco Manuel de Melo, é necessário, então, saber quais são elas. Afastando-se um pouco dos "sentimientos de

\footnotetext{
${ }^{466}$ Idem, Livro I, "Defensa de las Passiones, contra la Doctrina Estoyca", p.15.

467 Idem ibidem, p.16.

${ }^{468}$ Idem, Livro I, "Qual sea la Naturaleça de las Passiones, y en qual de la Potencias del Alma residen", p.27.
} 
Platon, y de Aristoteles" e seguindo a "opinion de Agostino", entende-se que o Amor é a única paixão que agita o homem, porque todos os movimentos que desordenam a alma não são outra coisa que amores disfarçados. Portanto,

sy ay muchas Passiones en el Hombre, es el Amor, el soberano de todas ellas; y que es tan absoluto Señor en su estado, que sus inferiores no emprenden cosa alguna, sino de baxo de sus mandamientos. Es el primer mobil que las lleua y como les dá el curso, les dá tambien el sosiego; el las retira y las aplaca, con su vista y sus exemplos. Tiene en fin el Amor tanto poder sobre las inclinaciones de nuestra Alma que su bondad, o su malicia, hace que nuestras inclinaciones, sean buenas, o malas. ${ }^{469}$

Por isso, conclui-se o livro I da Vitoria del Hombre assegurando-se ao amor a posição de "paixão mais violenta do homem". E à filosofia moral não cabe outra coisa senão dirigir o amor a um fim divino, "porque quando esta Passion fuere bien reglada, todas las otras la copiaran en sy mesmo; pues que el Hombre que bien supiere amar no será posseido de malos Deseos, ny vanas Esperanças". 470

No livro II, trata-se, em primeiro lugar, da corrupção da natureza causada pelo pecado original, que relegou ao homem, como castigo de sua culpa, a rebelião da carne contra o espírito. Devido a tal corrupção, a natureza tornou-se incapaz de regrar as paixões humanas e a razão, enfraquecida pelo pecado, passou a necessitar de socorro e ajuda para dominar esses movimentos da alma. Assim, foi preciso acudir à graça: "que en el Hombre, se hallan tantos excessos y contradiciones, que no puede la Raçon amansarlas consigo mesmo, y que padece males a quien la Naturaleça sin la Gracia no puede dar remedio". ${ }^{471}$ É apenas com a ajuda da graça que a razão pode moderar (e jamais eliminar completamente) as paixões; e esse é um dos aspectos fundamentais que diferenciam a filosofia cristã da doutrina estóica, "porque la Humildad cristiana, és enemiga de la vanidad Estoyca". ${ }^{472}$ Em termos cristãos, somente o excesso das paixões é culpável ou pernicioso, e não sua prática, como queriam os estóicos. Portanto,

\footnotetext{
${ }^{469}$ Idem, Livro I, "Del numero de las Passiones del Hombre", pp.37-38.

${ }^{470}$ Idem, Livro I, "Qual sea la mas violenta entre las Passiones del Hombre", p.46

${ }^{471}$ Idem, Livro II, "Que la Naturaleça por sy solamente no puede reglar las Passiones, del Hombre”, p.58.

${ }^{472}$ Idem, Livro II, "Que en el punto en que se hallan nuestras Passiones, és necessaria la Gracia para que se compongan", p.62.
} 
segundo Santo Agostinho, o verdadeiro inimigo é a concupiscência: estar isento dela é a perfeição, não segui-la é a batalha.

O livro III discute a condução das paixões, que é considerada uma das coisas mais gloriosas, porém mais difíceis, para se alcançar a vitória sobre o embate das virtudes e dos vícios. ${ }^{473} \mathrm{E}$ o exemplum dos heróis é fundamental nessa batalha. Nesse sentido, as seguintes palavras poderiam mostrar, com precisão, a exemplaridade das vidas de Florinda e Arnaldo, embora não se refiram a esses personagens:

Leemos sus vidas, como los capitanes suelen leer las de los Cesares; sobre sus hechos leuantamos el edeficio de las virtudes; porque en ellos encontramos aquellas famosas premissas que fundaron; las inocentes astucias que praticaron; los altos disignios que emprenderon, por acaudalar tan señaladas vitorias. Pues quales fueron los crudos combates destos inuencibles Cipiones? Sus Maximas más seguras fueron despreciar las proprias fuerças, pedir socorro al Cielo; esperar de la Gracia lo que no es licito esperar de la Naturaleça. ${ }^{474}$

Prosseguindo, lemos no texto que o escravo mais miserável é homem que se deixa levar por suas paixões. Estas são como grilhões que não prendem o corpo, mas o "íntimo da alma": a vontade, os pensamentos, os desejos. Por isso, os cativos das paixões, como bem mostrou Justo Lípsio no seu De Constantia, "por más que muden de tierra, jamás pueden mudar de condicion; son esclabos de baxo de los diademas, siruen a sus Passiones, quando señorean sus súbditos, y a toda parte donde se encaminan, allá van arrastando sus cadenas y conducindo sus señores dentro de sy proprios". ${ }^{475}$

Desse modo, é preciso moderar as paixões para depois encaminhá-las em direção à virtude. Na busca por essa moderação, três coisas são fundamentais: em primeiro lugar, faz-se necessário reconhecer como a desobediência da paixão turba a alma; em segundo, deve-se persuadir a razão que esteja sempre vigilante sobre os "assuntos" (sugetos) que podem concitar as paixões, considerando sua natureza e movimentos, para que jamais enganem os homens por achá-los desapercebidos; por fim,

\footnotetext{
473 "Pues sy la difficultad que acompaña esta pendencia espanta, la gloria que se le sigue, nos deue alentar el animo; porque el Cielo no la mira empresa más ilustre, ny la Tierra, la tiene más gloriosa: que ver vn hombre triunfante de sus Passiones" (Idem, Livro III, "Que no ay cosa más gloriosa, ny más difficil que la conducion de las Passiones", p.82).

${ }^{474}$ Idem ibidem, p.84.

475 Idem, Livro III, "Que no ay tan miserable esclabo como el Hombre, que se dexa lleuar de sus Passiones", p.86.
} 
deve-se, sobretudo, estudar a natureza das paixões a serem moderadas e conduzidas, porque algumas delas são violentas e para reduzi-las à obediência é necessário usar de severidades. Assim, somente depois de despojadas de sua ferocidade natural, ou seja, após as paixões serem domadas, é que entra em cena a razão dispondo-as utilmente, "por cuyos medios, no forma la Virtud disignios que no execute felizmente en sus u ayuda". ${ }^{476} \mathrm{E}$ em qualquer estado em que se encontrem as paixões, a razão pode governálas, pois mesmo depois do pecado e desobediência dos primeiros "Pais", elas ainda mantêm alguma "sombra de pureça". Com argumentos muito semelhantes aos estóicos, afirma-se, então, que a fortuna consiste na disposição do homem e a vitória depende da força de seus braços. ${ }^{477}$

Passando ao livro IV da Vitoria del Hombre, vemos que seu tema é o “comércio" das paixões. Logo no começo desse livro, é feita, ou melhor, é reproduzida uma antiga e conhecida censura aos estóicos: a filosofia da Stoa "promete mudar los Hombres, y hacerlos casy iguales con los Dioses; eleuarles sobre la condicion mortal, y poner debaxo de sus plantas, los truenos, y las tempestades". ${ }^{478}$ Recordemos o que já dizia Diógenes Laércio sobre a doutrina estóica: “Os sábios são criaturas divinas, pois têm em si, por assim dizer, a divindade" (Vidas e Doutrinas dos Filósofos Ilustres, VII, 119). Portanto, para um cristão, como Jean-François Senault ou D. Francisco Manuel de Melo, desnudar a alma de suas paixões é querer que o homem seja Deus, o que é um objetivo impossível defendido, com soberba, pela escola estóica. As paixões, na verdade, se corretamente utilizadas, são instrumentos das virtudes; ${ }^{479}$ idéia essa que se aproxima muita mais daquela dos peripatéticos, como declara o próprio D. Francisco Manuel no texto.

Contudo, embora as paixões sejam instrumenos das virtudes, são também fundamento e raiz dos vícios, estando de tal maneira imbricados esses dois "contrários" que se torna muito difícil distingui-los. Vale a pena ler o techo em que essa contradição é explicada e resolvida:

\footnotetext{
${ }^{476}$ Idem, Livro III, “Que será fuerça moderar nuestra Passiones para poder encaminarlas", p.99.

477 "Por lo qual nuestra Fortuna consiste en nuestra disposicion; nuestra Vitoria depende de nuestros braços; nuestra ventura anda vinclada a nuestro Deseo: en tal manera, que para adquirir todos estos Bienes, no es menester mayor animo, que el que Dios nos ha dado assistido de su Gracia" (Idem, Livro III, "Que en todo estado en que se hallen nuestras Passiones, las puede gouernar la Raçon", p.106).

${ }_{478}$ Idem, Livro IV, "Que las Passiones pueden ser el Cimiento de las Virtudes", p.113.

479 "De aqui sacamos vna máxima indubitable entre los Filosofos donde se affirma: Que las Passiones, son los instrumentos de las Virtudes: y que ellas no tienen ocupaciones más nobles, que armarse en su fauor, pelear en su socorro, y vengarlas de sus enemigos. Porque assy como las madres nunca son tan animosas, como quando defienden sus hijos; los Affectos de nuestra Alma, nunca son más vigorosos, como quando defienden sus effectos" (Idem ibidem, 117).
} 
Finalmente hallamos, que el solar de las Passiones, no está más apartado de las rayas del Vicio, que vicino a las de la Virtud: y assy como en la primera confusion del Caos, el Fuego se hallaua de mistura con el Agua, en las Affeciones del Alma, está el Mal mesclado con el Bien, sacando destas funestas minas, el yerro, reuoluido con el oro. Deue por esto el Hombre hallarse siempre cuidadoso; y entendiendo, que encierra la Vida, y la Muerte dentro de sy mesmo, es obligado a gouernarse con tanta prudencia, como aquellos, que manejan el veneno, ó que caminan sobre la dificil, y peligrosa cumbre. ${ }^{480}$

O que novamente se assegura no livro IV é que não existem paixões que não possam ser transformadas em virtudes, acrescentando-se que os cristãos fazem um bom uso delas desde que visem à glória de Deus e à salvação de seus espíritos. Quanto às virtudes, seu exercício é uma eterna guerra contra os vícios, sendo que elas nos foram dadas "solamente para assistirnos en el progresso desta vida peligrosa; y que son grados para subir azia aquella altíssima felicidad, que consiste en la possesion del sumo Bien". ${ }^{481}$ E um dos exercícios mais úteis e difíceis das virtudes é justamente governar as paixões, destacando-se os papéis fundamentais das quatro principais virtudes - a prudência, a temperança, a fortaleza e a justiça -, que devem ser empregadas em conjunto nessa difícil guerra. “Assy la Naturaleça acordandose con 1 aGracia, quedará la Culpa destruída, y el Hombre vitorioso. Los mouimientos de su Alma siendo niuelados por la Raçon, goçarán de vn perfeitissimo sosiego". 482

Já o livro $\mathrm{V}$ trata do poder das paixões sobre a vontade dos homens. O melhor e mais seguro remédio para evitá-las é seu exame, reconhecendo-as como correntes que escravizam o homem. Para nos auxiliar no governo das paixões todas as ciências e artes são defeituosas, a não ser a filosofia moral, que é aquela que mais pode nos ajudar a "vencer la profia, y la batalla de enemigos, que son tan obstinados, como insolentes". 483

A partir do livro VI até o fim da Vitoria del Hombre são estudadas as principais paixões humanas, começando por aquela que origina todas as outras: o amor, como já mencionamos. Essas análises examinam cada paixão em particular e se dão da

\footnotetext{
${ }^{480}$ Idem, Livro IV, “Que las Passiones son tambien la rayz delos Vícios”, pp.122-123.

${ }^{481}$ Idem, Livro IV, "Que el principal exercício de la Virtud, es el gouierno de las Passiones humanas", 137.

${ }^{482}$ Idem ibidem, p. 142.

${ }^{483}$ Idem, Livro V, "Que las Artes engañan a los Hombres por el remedio de sus Passiones”, p.160.
} 
seguinte forma: num primeiro momento são explicados sua natureza, suas propriedades e seus efeitos; em seguida, determina-se qual é o mau uso da paixão em questão; e, por fim, como é (e deve ser) seu bom uso. As paixões estudadas são: o amor, o ódio, o desejo, o arrependimento, a "fuga" (huyda), a esperança, a desesperación, a ousadia, o temor, a ira, o gosto e a dor. Ultrapassa os limites deste nosso trabalho acompanhar, uma a uma, essas análises. Podemos destacar apenas que o amor é considerado a "verdadeira" ou fundamental paixão humana, pois ele é "vn congregado de todas las Passiones del Hombre, el qual segun sus diuersos estados reciue ó toma nombres differentes". 484

Enfim, o que observamos na Vitoria del Hombre de D. Francisco Manuel de Melo é que, assim como nas obras de seus antecessores, de Lípsio a Quevedo, há um evidente objetivo de conciliar as filosofias antigas (em particular a estóica) com a cristã. No entanto, a filosofia cristã, desde sua origem, misturou-se com as doutrinas antigas, sendo difícil (talvez impossível) separar uma das outras. Na Vitoria del Hombre sobre el Combate de Virtudes y Vícios, não há um "triunfo da filosofia cristã contra a doutrina estóica", como parece sugerir o subtítulo da obra, mas a composição de uma doutrina estóico-cristã, presença marcante, e mal compreendida pelos estudiosos, nos textos de importantes autores dos séculos XVI e XVII. Maria Lucília Gonçalves Pires explica acertadamente que um dos principais objetivos da Vitoria del Hombre é "a valorização da graça como auxiliar indispensável da razão para que o homem possa distinguir, no plano do conhecimento como no da ação, o bom do mau uso das paixões, consideradas também aqui inseparáveis da natureza humana". ${ }^{485}$ Porém, isso não significa que se constituiu assim uma doutrina antiestóica, pois a própria filosofia cristã é desde o começo, entre outras coisas, estóica.

Na leitura dos textos desses autores, de Justo Lípsio a D. Francisco Manuel de Melo, uma constante parece se impor: a "filosofia estóica" do período é uma doutrina estóico-cristã. Em termos cristãos, não se pode defender a apatheia, o suicídio, o Fatum, o sábio igual aos deuses (ou a Deus) etc. Entretanto, isso não implica uma doutrina, filosofia ou seita antiestóica; antes, é uma clara demonstração de apropriação de ensinamentos dos antigos, inseridos num mundo cristão. É como cristãos que esses

\footnotetext{
${ }^{484}$ Idem, Livro VI, "De la Naturaleça, de las Propriedades, y de los Effetos del Amor”, p.180.

485 "O tema da «guerra interior» nas Obras Métricas de D. Francisco Manuel de Melo", op.cit., p.67.
} 
autores escrevem, mas nem por isso não escrevem como estóicos. São doutrinas afinadas desde o princípio, talvez desde Jó. E é com Jó também que se tem sua síntese.

Relembremos o Livro. Jó era um homem íntegro, reto, temente a Deus e que fugia do mal; possuía muitos bens e vivia em alegria com a família e com os amigos. No entanto, Satanás foi um dia até Deus e disse que Jó somente era um homem tão íntegro e justo, pois sempre tivera a prosperidade a seu favor. Assim, Deus permitiu que Satanás "provasse" a fé e constância de Jó. A partir daí as desgraças e infortúnios recaíram todos de uma vez sobre esse homem: perdeu toda sua riqueza e prosperidade; morreram todos seus filhos; e se afastaram as pessoas que lhe eram mais queridas. Jó não blasfemou, mas aceitou todas as desgraças. Satanás, então, feriu-lhe o corpo. Jó passou a se lamentar e sofreu a represália de alguns amigos que vieram falar com ele. Tais amigos disseram que Deus só pune aquele que é iníquo e injusto, aquele que cometeu pecado; por isso, Jó deveria ter feito algo de errado para merecer a ira divina. Num determinado momento, Deus interveio na conversa e falou com Jó: afirmou que os segredos divinos são por demais superiores à inteligência humana e que a providência e o poder de Deus estão acima de todas as coisas humanas, vendo e governando tudo que há debaixo do céu. Jó, então, se curvou diante de Deus e admitiu que lhe faltou sabedoria para aceitar os planos divinos. Como recompensa à firmeza de Jó, que, embora tenha se sentido desamparado em alguns momentos, no final reconheceu a providência do Poder Supremo, Deus restaurou toda a prosperidade daquele homem, dando-lhe em dobro tudo o que antes ele tinha e lhe fora tirado. Assim viveu Jó, repleto de prosperidade e de alegria, cercado de muitos filhos e amigos, até que a morte, que veio em idade bastante avançada, encerrou seus dias.

O sábio estóico-cristão, à imitação de Jó, aceita os desígnios da Providência, pois está ciente de que a disposição divina é misteriosa e que, muitas vezes, os justos também sofrem sem culpa nenhuma, mas que, no fim, Deus recompensa a virtude desconhecida pelos homens.

Em seus comentários ao Livro de Jó, Quevedo elogia, como fica evidente logo no título La constancia y paciencia del santo Job, a constância (estóica) e a paciência (cristã) do personagem bíblico. Composição essa desenvolvida na comparação exemplar entre as palavras de Sêneca no De Prouidentia (V, 5-6) e as obras de Jó que, depois de perder tudo, raspou a cabeça e rasgou as roupas, desnudando-se para dar a Deus o que lhe restava, pois Ele já lhe havia tirado o que tinha: 
Estas palabras díjolas el filósofo con los labios, Job con las obras. Todo eso pronuncia la acción referida. Paciencia tan generosa, tan liberal resignación en Dios, sentimiento tan cortésmente santo, queja tan inflamada de amor, no es de casta de conocimiento gentil. Habló el idólatra el silencio del texto; vióle como los estoicos, y dijo lo que coligió. Séales premio a Séneca y a él que suplen con sus plumas parte de comento a libro tan sagrado, y con cláusulas en que se conoce interior médula de su mente, dignas de que cada día las pronuncien afectos católicos. Ya hemos visto las acciones donde están sin voz: veamos las palabras donde están con ella. ${ }^{486}$

Se as palavras de Sêneca são as obras de Jó, este é diseño de Cristo:

Prodigioso diseño fué Job de Cristo; mostraré la diferencia. Respecto de Cristo, fué Job un dibujo hecho con carbón; y Cristo la pintura admirable que da ser con hermosísimos colores a lo que confusas y revueltas, ni sé si diré mejor que prometieron o amargaron los borrones de las llagas, heridas y aflicción de Job a las del Hijo de Dios; va lo que diré, sin salir del dibujo, a lo que se borda después en él; aquéllas fueron picaduras de alfiler, y éstas clavos, martillos y lanzada; aquéllas en un papel; éstas en la tela riquísima de su soberana humanidad. ${ }^{487}$

Assim, Jó, cristianizando Sêneca e estoicizando Cristo, é um sábio cristão ou um santo estóico; é o exemplum, pintado com tintas estóicas, que retrata o viver cristão. Por isso é síntese da doutrina estóico-cristã, que ensina a constância na vida e a paciência na morte, com a esperança de se alcançar a perfecta ratio na ciuitas Dei. Mas sempre haverá a distância que separa o mundo, pátria do sábio, do céu, casa de Deus, porque pecamos e estamos condenados a sermos (cristãos) humanos, e jamais sábios divinos, jamais enquanto o corpo for carne e a alma, animus.

\footnotetext{
${ }^{486}$ Obras completas, op.cit., p.1497.

${ }^{487}$ Idem, p. 1538.
} 


\section{Capítulo 4}

\section{Ensinamentos estóico-cristãos na narração da Constante Florinda}

Na narração da Constante Florinda, os ensinamentos legados, semelhantes aos que expusemos no capítulo anterior, encaminham os leitores para um viver virtuoso, ou seja, para uma vida cristã. Muitos desses ensinamentos dependem da filosofia moral estóica, fonte constante em textos dos séculos XVI e XVII, como vimos. Nessa narração, no entanto, não há referências explícitas nem aos "estóicos" (Sêneca é citado como auctoritas antiga e não como filósofo estóico) nem à sua "doutrina", "filosofia" ou "seita", ${ }^{488}$ diferentemente do que pudemos observar, por exemplo, nos escritos de Quevedo. Assim, nossa análise é que evidenciará a importância da doutrina estóica na narração da Constante Florinda, mais especificamente, nos argumentos da persona que narra. Naquela narração é que se constitui este narrador, como já dissemos. Portanto, ele é um personagem, ou melhor, persona que tem como incumbência narrar; em suas "falas", principalmente, é que buscaremos os preceitos estóico-cristãos. Enfim, mostraremos que na narração dos infortúnios trágicos de Florinda e Arnaldo configuram-se exempla estóicos que ensinam aos leitores um viver cristão.

Isso posto, vamos à análise. Destacaremos, na narração, aqueles trechos que nos parecem ecoar elementos da doutrina estóica e, sempre que possível, relacionandoos com a história narrada. Comecemos, pois, pela primeira parte da Constante Florinda. No fim do trágico capítulo IV, no qual se dá a suposta morte de Arnaldo, pouco antes de dom Luís e seus comparsas atacarem o rapaz, o narrador anuncia a tragédia que está por vir: "Mas, ai dor, que não há contentamento nem alegrias que não sejam vigílias de males; porque estando Arnaldo na maior bonança de seus gostos lhe sobreveio a tempestade dos maiores trabalhos". ${ }^{489}$ Nessas palavras ficam evidentes topoi ${ }^{490}$ antigos

\footnotetext{
${ }^{488}$ Vale ressaltar, porém, que na "Dedicatória" (ou seja, não na narração propriamente dita) da primeira parte da Constante Florinda, o autor (não se trata do narrador nesse caso) menciona a "opinião dos Estóicos": "E como pela definição da cousa se alcança mais o conhecimento dela, na opinião dos Estóicos muito mais esta verdade se declara. Nobilitas, dizem eles, et splendor quidam, non aliunde veniens quam ex ipsa virtute. E é tão grande bem ao nobre ser acompanhado de virtude que não só a si mas a todos os antepassados acrescenta nobreza" (Infortúnios trágicos da constante Florinda, "Dedicatória", p. 27).

${ }^{489}$ Idem, capítulo IV, p.64.

${ }^{490}$ Acerca da "tópica" em geral, lembremos o que diz Curtius: "No antigo sistema da retórica, a tópica é o celeiro de provisões. Contém os mais variados pensamentos: os que podem empregar-se em quaisquer discursos e escritos em geral" (Literatura Européia e Idade Média Latina, op.cit., p.121).
} 
muito explorados nos séculos XVI e XVII: a efemeridade dos bens da vida e a eterna mudança das coisas do mundo. Segundo José Antonio Maravall, acentuar a inconstância das coisas é uma característica marcante da "cultura barroca" (usando a expressão do autor): "Movilidad, cambio, inconstancia: todas las cosas son móviles y pasajeras; todo escapa y cambia; todo se mueve, sube o baja, se traslada, se arremolina" ${ }^{491}$ O que acaba suscitando, conseqüentemente, a noção de fortuna: "La fortuna, en el siglo XVII, es una imagen retórica de la idea de mutabilidad del mundo: se la concibe como motor de los cambios y causa del movimiento que agita la esfera de los humanos". ${ }^{492}$ Em termos mais precisos e que dizem muito mais respeito à Constante Florinda, assinala Adma Muhana:

\begin{abstract}
No século XVII, "Fortuna" é identificada a uma entidade divina, a quem os Antigos atribuíam a causa de todos os acontecimentos, prósperos ou adversos: a Tó $\boldsymbol{\eta}$ dos gregos, o Acaso imprevisível, que governa tudo, e que, nas epopéias em prosa gregas dos séculos II a IV, imitadas pelas do XVII, é o principal fator a mover os acontecimentos, equivalente a um Destino malévolo, sem justiça nem razão de ser. A causa absoluta é ela mesma desprovida de causa. ${ }^{493}$
\end{abstract}

Porém, contra o sábio estóico nada pode a Fortuna, pois, invencível, ele vencea, como afirma Sêneca para concluir seu De Constantia Sapientis: "esse aliquid inuictum, esse aliquem in quem nihil fortuna possit, e re publica est generis humani [est]" (XIX, 4). Portanto, se os inimigos humanos golpearam Arnaldo, a Fortuna golpeou Florinda, tomando dela o que mais amava, mas a donzela, como um sábio estóico, reagiu lutando contra a "deusa cega" e, jurando manter a palavra dada a seu amado (que, para ela, estava morto), mostrou-se um exemplo de constância diante de um infortúnio tão trágico: "E como ela fosse tão firme e constante que antes esperaria a morte que quebrar sua palavra, não dando conta a pessoa alguma determinou de se partir com ânimo de se vingar". ${ }^{494}$ Com esse "ânimo de se vingar" de Florinda, o narrador modera a apatheia e torna a personagem mais humana e, conseqüentemente,

\footnotetext{
${ }^{491}$ La cultura del barroco: análisis de una estructura histórica. Barcelona: Ariel, 1990, p.371.

492 Idem, p.388.

493 "Posfácio" aos Infortúnios trágicos da constante Florinda, op.cit., p.329.

${ }^{494}$ Infortúnios trágicos da constante Florinda, capítulo V, p.67.
} 
menos igual a Deus, como um estóico-cristão e não como um sábio estóico antigo, vizinho e próximo dos deuses, na verdade, um ser divino, exceto por sua mortalidade. ${ }^{495}$ Ainda que não seja um dito do narrador, vale a pena mencionar a sentença de Leandro (como sabemos, Florinda) sobre a "Honra", quando foi essa a palavra sorteada na "disputa" em que se envolveu na Universidade de Bolonha, episódio ao qual já nos referimos. Diz, então, Leandro: “As honras do mundo hão-se de merecer, mas não se hão de procurar: porque a tal honra é melhor merecê-la sem a ter, que tê-la não a merecendo". ${ }^{496}$ Nota-se aí um desprezo pelos bens mundanos, um contemptus mundi ou desengaño, que ficará ainda mais evidente na segunda parte da Constante Florinda. Por enquanto, recordemos o tom desenganado das primeiras frases de "El mundo por de dentro", um dos Sueños de Quevedo:

Es nuestro deseo siempre peregrino en la cosas desta vida, y así, con vana solicitud anda de unas en otras sin saber hallar patria ni descanso; aliméntase de la variedad y diviértese con ella; tiene por ejercicio el apetito, y este nace de la ignorancia de las cosas, pues si las conociera cuando codicioso y desalentado las busca, así las aborreciera como cuando arrepentido las desprecia. Y es de considerar la fuerza grande que tiene, pues promete y persuade tanta hermosura en los deleites y gustos, lo cual dura solo en la pretensión dellos, porque en llegando cualquiera a ser poseedor es juntamente descontento. El mundo, que a nuestro deseo sabe la condición, para lisonjearla, pónese delante mudable y vario, porque la novedad y diferencia es el afeite con que más nos atrae. Con esto acaricia nuestros deseos, llévalos tras sí, y ellos a nosostros. $^{497}$

Na sentença do narrador que encerra o capítulo XVII dos Infortúnios trágicos da Constante Florinda, o ensinamento é também de desengano. Como sabemos, Leandro conheceu quatro formosas donzelas num castelo (Gracinda, Leonora, Cassandra e Gerarda), sendo que uma delas, Gracinda, apaixonou-se por ele. O "mancebo" partiu do castelo para evitar confusões, porém Gracinda fugiu para persegui-

\footnotetext{
495 "Non potest ergo quisquam aut nocere sapienti aut prodesse, quoniam diuina nec iuuari desiderant nec laedi possunt, sapiens autem uicinus proximusque dis consistit, excepta mortalitate similis deo" (De Constantia Sapientis, VIII, 2).

${ }^{496}$ Infortúnios trágicos da constante Florinda, capítulo XII, p.115.

${ }^{497}$ Los sueños. Edición de Ignacio Arellano. $4^{\text {a }}$ edición. Madrid: Catedra, 2003, p.484-485.
} 
lo e conseguiu encontrá-lo numa "venda". Com a intenção de deixar a donzela em algum lugar mais seguro e peregrinar sozinho, Leandro, ludibriando-a, convida-a para andar em sua companhia. Com as seguintes palavras o narrador resume o engano no qual estava envolvido a moça, engano que é estendido aos instáveis bens da "ventura":

Com esta promessa ficou a fermosa Gracinda tão satisfeita como agradecida, e tão alegre e contente como quem lhe parecia que possuindo este bem dela tão desejado não podia já faltar-lhe algum do mundo, ainda que receosa por serem bens que lhe oferecia a ventura, que estes estão menos seguros quando se mostram mais prósperos. ${ }^{498}$

No capítulo seguinte (XVIII), o irmão de Gracinda depara-se, por acaso, com ela e Leandro numa ermida. E, "levado de grande paixão", atacou-os com um punhal e somente não os matou porque os criados não permitiram. Mas Leandro acaba sendo preso e levado para Veneza e Gracinda encerrada num convento. Nesse momento, lembra o narrador por que o personagem enfrentava, corajosamente, tão grandes infortúnios: "Finalmente estes foram uns dos maiores trabalhos em que Leandro mostrou a fineza de sua constância e leal peito, tendo sempre em ele o retrato de seu Arnaldo, que lhe servia do maior alívio". ${ }^{499}$ Tal constância é amplificada na descrição dos sofrimentos de Leandro na prisão,

metido em o escuro e tenebroso cárcere em que sem culpa estava; a aspereza do qual the tinha tornado seu encarnado rostro em pálido e macilento, seu fermoso corpo enfraquecido; suas carnes mui minguadas; seus tenros e delicados membros consumidos, seu coração mui aflito, seus claros olhos cegos de derramar lágrimas; seu ânimo cansado de dar suspiros; e o remédio de suas esperanças prolongado: porém não que desfalecesse nunca seu constante peito: antes na força dos maiores trabalhos fazia novas protestações de não descobrir quem era, enquanto pudesse encobrir ao mundo sua pessoa, ou chegasse a tanto perigo sua vida que só em descobri-lo estivesse o remédio dela: o

\footnotetext{
${ }^{498}$ Infortúnios trágicos da constante Florinda, capítulo XVII, p.156.

${ }^{499}$ Idem, capítulo XVIII, p.159.
} 
que prometia tendo em as mãos a estampa de seu querido Arnaldo, que de alívio lhe servia nas maiores tribulações e trabalhos. ${ }^{500}$

Como vimos, a constância é uma virtude fundamental para o sábio, desde Sêneca, no De Constantia Sapientis, passando pelo De Constantia de Lípsio, até Du Vair, no De la constance. Da mesma forma, logo no título da obra de Rebelo, Infortúnios trágicos da Constante Florinda, é possível perceber a relevância do termo. ${ }^{501}$ Como explica Adma Muhana,

constância é a virtude maior daqueles que, em privado e em público, praticam habitualmente atos justos e sábios, por compreenderem que a Providência divina rege o universo; mesmo nas ocasiões em que a Fortuna parece conduzir os acontecimentos, ela é, por assim dizer, serva da Providência. Volubilidade, fugacidade, transitoriedade, provisoriedade da existência terrena - termos que comparecem insistentemente na prosa e na poesia seiscentistas - são contingências a serem combatidas pela Constância, único antídoto à disposição dos homens prudentes, quais sejam, no século XVII ibérico, homens tementes a Deus, ao Papa e ao Rei. Ser constante é uma demonstração de sabedoria fundada numa razão fiel e piedosa, ou seja, conhecedora dos princípios - Deus - e dos fins - o Juízo Final -, sendo por isso a principal virtude e epíteto de Florinda. ${ }^{502}$

Voltaremos a discutir a noção de constância em outros momentos da nossa análise, pois, como percebemos, ela é essencial não apenas para a doutrina estóico-cristã quinhentista e seiscentista, mas especialmente para a obra de Rebelo, o que demonstra a afinidade entre este texto e aquela doutrina, sintonia que não é "novidade" para o século XVII.

De caráter nitidamente estóico, são os capítulos em que Leandro, depois de sofrer um naufrágio, passa a conviver com o "ermitão". Assim é narrado o encontro, que ocorreu junto a uma fonte que nascia do pé de um alto rochedo:

\footnotetext{
${ }^{500}$ Idem ibidem, pp.160-161.

501 Recordemos também que Epicteto sempre fala da virtude de "firmeza" ou "constância". Ver, por exemplo, Diatribes, I, cap.29.

502 "Posfácio", op.cit., p.339.
} 
E sentando-se em uma mesa que de jaspe preto estava feita, pera dali contemplar com mais descanso a curiosidade dela; sentiu pegadas como de pessoa que vinha dirigida à fonte, e erguendo-se em pé atemorizado, levando os olhos pera aquela parte, viu que chegava um homem tão grave e venerando em sua pessoa, como áspero e penitente em seu vestido, pelo que assim do hábito como da barba mui branca que pelos peitos lhe dava e de umas contas mui grossas que em a mão trazia, julgou ser algum ermitão de santa vida que em tais e tão ásperas terras fazia penitência. Vendo pois o velho a Leandro (ainda que maltratado do naufrágio passado) tão belo e gentil-homem, ficou espantado sem dizer palavra por um espaço, e vendo Leandro que devia de lhe nascer da novidade de sua vista, foi-se a ele pera se deitar a seus pés: e conhecendo sua determinação, pondo em o chão uma quarta que em a mão trazia, o recebeu em os braços. ${ }^{503}$

Após esse encontro, o ermitão levou Leandro ao alto do monte para lhe mostrar as "ruínas" que lá havia. Logo na primeira "ruína" com que se deparam, percebe-se o desengaño que fica como ensinamento, para os personagens e também para os leitores:

a primeira cousa digna de notar que viram foi uma grande e fermosa coluna de pedra jaspe mui clara; em o alto dela estava feito da mesma pedra um bem-apessoado homem, assim do corpo, como de verônica de rostro, e as mãos abertas, caindo-lhes delas um rótulo da mesma pedra com letras de ouro que diziam em língua latina: NIHIL FIDENDUM EST HUMANAE PROSPERITATI.

E o narrador faz questão de traduzir as palavras latinas: "Que querem dizer em nossa linguagem: Que nenhuma cousa se há de confiar na prosperidade humana". ${ }^{504}$

Em sua já mencionada Nova arte de conceitos, escreve Francisco Leitão Ferreira:

Os Symbolos, Geroglificos \& Emprezas são também sinaes sensíveis dos conceytos: são engenhosos, porque allusivos: \& figurados, porque

\footnotetext{
${ }^{503}$ Infortúnios trágicos da constante Florinda, capítulo XXIV, pp.201-202.

${ }^{504}$ Idem, capítulo XXV, p.205.
} 
metafóricos. Neles hua cousa se vê \& outra se entende: manifestam o corpo \& occultam a alma; os olhos admiram a figura, \& o figurado só o entendimento o percebe; \& por isso semelhantes sinaes são hus quase contraditórios sensíveis, pois a vista conhece o objeto \& ignora o significado: está evidente, \& parece enigma; a llusão veste-se de illusão. ${ }^{505}$

Porém, o que vêem Leandro e o ermitão nas ruínas no alto do monte não são "empresas", definidas por Robert Klein como um "símbolo composto, em princípio, de uma imagem e uma sentença, e que serve para exprimir uma regra de vida ou um programa pessoal de seu produtor"; 506 na verdade, são típicos "emblemas", que, como afirma João Adolfo Hansen, "eram mosaicos de esmalte ou pedra, incrustações, filigranas e guirlandas de vasos, colunas, paredes, móveis e roupas"; mais ainda, a sentença, "alma" do emblema, "é formulada como tradução da imagem e sua finalidade é moralizadora: lições sobre a verdadeira amizade, sobre a temperança, sobre as virtudes e vícios do corpo, sobre a reta crença em Deus etc.". 507

E alguns desses emblemas da primeira parte da Constante Florinda, descritos e explicados pelo narrador, parecem querer ensinar uma moral com traços estóicos, como pudemos notar logo no primeiro já citado. Vejamos alguns outros:

E a outro tanto do caminho, já bem no cume do alto monte, estava uma mui alta coluna de pedra verde com engastes de jaspe negro, e em cima uma mulher ornada de curiosos vestidos da mesma pedra, com uma trombeta em a boca, e com um rótulo em a mão esquerda com letras de ouro que diziam: FAMA VOLAT.

Explica o narrador: "Que quer dizer: Já a fama destas grandezas voa pelo mundo". 508 Como é sabido, a principal fonte da expressão "fama uolat" é Virgílio (Eneida, III, 121; VII, 392; VIII, 554) ${ }^{509} \mathrm{e}$, por isso, não se poderia dizer que é um ensinamento

\footnotetext{
${ }^{505}$ Apud Hansen, J. A. Alegoria - construção e interpretação da metáfora. São Paulo: Hedra; Campinas: Editora da Unicamp, 2006, p.191.

506 "A teoria da expressão figurada nos tratados italianos sobre as imprese, 155-1612". In: A Forma e o Inteligivel: ensaios sobre o Renascimento e a arte moderna. Trad. Cely Arena. São Paulo: Edusp, 1998, p.117.

${ }_{507}$ Alegoria - construção e interpretação da metáfora, op.cit., pp.200 e 202.

${ }^{508}$ Infortúnios trágicos da constante Florinda, capítulo XXV, p.207.

${ }^{509}$ A "tradução" que o narrador faz parece tomar por base o verso de Virgílio: "Fama uolat paruam subito uolgata per urbem" (Eneida, VIII, 554).
} 
originariamente estóico. No entanto, vale lembrar que esse ensinamento não é estranho à doutrina da antiga Stoa, que repudiava todo tipo de fama, e se assemelha ainda mais às idéias de Sêneca, que "había propuesto una distinción entre la fama no genuína del Vulgus: la 'gloria', y la verdadera, la 'claritas': «Gloria multorum iddiciis constat, claritas bonorum»y «claritas... potest et unius boni uiri iudicio esse contenta» (Ep. ad Luc., 102, 17, y 11 respectivamente)". ${ }^{510}$ Além disso, como já mostramos, não podemos nos esquecer que Quevedo, em sua Doctrina Estoica, colocou Virgílio entre os “estóicos romanos", talvez por encontrar na poesia do mantuano apreciações como essa sobre a fama.

Prossigamos com os emblemas. Leandro, sempre guiado pelo ermitão, vê as "figuras" de duas mulheres, "uma muito fermosa e bem lavrada, outra feia e malcomposta, e ao pé, com letras brancas escritas em jaspe preto, estas palavras: VIRTUS EST CONSTANS, FORTUNA FALAX (A virtude é constante, e a fortuna falsa)". ${ }^{511}$ Esse emblema pode ser entendido como uma síntese da "moral" da história de Florinda. Aquele que almeja a bem-aventurança deve ter uma vida pautada pela virtude, sempre constante, e reconhecer o engaño que é a Fortuna. Essa idéia remonta a preceitos básicos dos estóicos, a muitos dos quais já nos referimos. Em resumo, a virtude é aquela que permite ao sábio combater a Fortuna; e, no caso de Florinda, sua constância é que torna sua alma, feito pedra ou diamante, invulnerável aos infortúnios, pois, conforme Sêneca, "sapientis animus solidus est" (De Constatia Sapientis, III, 5). ${ }^{512}$

Outro emblema, que também parece dialogar com a ética estóica, merece ser mencionado:

Estava logo uma figura de mulher mui junta e unida com outra, ambas mui bem ornadas de vestidos de jaspe mui alvo em extremo; e ao pé estavam estas letras em pedra preta aveiada de branco: NULA EST

\footnotetext{
${ }^{510}$ Blüher, K. A. Séneca en España, op.cit., p.574.

${ }^{511}$ Infortúnios trágicos da constante Florinda, capítulo XXV, p.209.

${ }^{512}$ Vale a pena transcrever todo o trecho do De Constantia Sapientis em que a comparação do sapientis animus às pedras e aos diamantes é desenvolvida: "Hoc igitur dico, sapientem nulli esse iniuriae obnoxium; itaque non refert quam multa in illum coiciantur tela, cum sit nulli penetrabilis. Quomodo quorundam lapidum inexpugnabilis ferro duritia est nec secari adamas aut caedi uel deteri potest sed incurrentia ultro retundit, quemadmodum quaedam non possunt igne consumi sed flamma circumfusa rigorem suum habitumque conseruant, quemadmodum proiecti quidam in altum scopuli mare frangunt nec ipsi ulla saeuitiae uestigia tot uerberati saeculis ostentant, ita sapientis animus solidus est et id roboris collegit ut tam tutus sit ab iniuria quam illa quae rettuli" (III, 5).
} 
VIRTUS SINE RATIONE (Não há virtude, se não for medida pela rezão). ${ }^{513}$

Essa sentença remete a discussões que determinaram a doutrina estóica: o bem ou fim último do homem, ou seja, secundum naturam uiuere. Como vimos, esse assunto é cuidadosamente trabalhado por Lípsio (Manuductio ad Stoicam Philosophiam, livro II, dissertações XIII a XX). Relembrando: Lípsio diz que tudo começou com a homologia ou convenientiam de Zenon, à qual Cleantes teria adicionado a natureza: convenienter naturae vivere, e, mais ainda, viver de acordo com a natureza comum; essa natura communis é a Lei e a Razão universais, ou seja, é o próprio Deus. Crisipo, então, teria dito que a natureza própria ao homem é a Razão, e deve-se viver em conformidade com a ratio perfecta. Por fim, a quarta e última tese afirma que o Bem é "viver segundo a virtude". Assim, conclui Lípsio, "virtus rationem sequitur, haec naturam, ista Deum”. Como se observa, para os estóicos a virtude (o soberano bem) segue a razão; e tal dependência entre essas duas noções, fundamentais para a filosofia estóica, está reafirmada na tradução do narrador da sentença latina do emblema: "Não há virtude, se não for medida pela rezão". Medir pela razão talvez seja não se deixar levar pela “opinião", que julga a glória, por exemplo, um verdadeiro bem, mas, como ensina Sêneca, "gloria umbra uirtutis est" (Ep. ad Luc., LXXIX, 13).

Ainda sobre a virtude, Leandro viu outro emblema na companhia do ermitão: a figura de uma mulher talhada em jaspe branco, "tendo a seus pés um homem mui feio de jaspe negro, e junto umas letras verdes em jaspe vermelho que diziam: LAUDATUR VIRTUS, VITUPERATUR VIITUM (A virtude louva-se, e o vício vitupera-se)". ${ }^{514}$ Como bem resume Epicteto (Diatribes, II, cap.19), todas as virtudes são boas, isto é, são o próprio bem; e os vícios são maus, ou seja, são o mal; quanto às demais coisas, são "indiferentes" (adiaphora), tais como a riqueza, a saúde, a vida, a morte, o prazer e a dor. Portanto, se a virtude é dependente da razão, não o é, de forma alguma, do vício, como assinala Sêneca no De Ira: "numquam enim uirtus uitio adiuuanda est se contenta" (I, IX, 1). A uirtus se basta a si mesma e é um importante instrumento para quem pretende governar bem muitos homens, como se lê no De Clementia, ou, ainda, para quem simplesmente quer atrair para si a atenção das pessoas, como se vê no seguinte emblema: "estava em uma cadeira assentada uma mulher mui bem ornada; e

\footnotetext{
${ }^{513}$ Infortúnios trágicos da constante Florinda, capítulo XXV, pp.209-210.

${ }^{514}$ Idem ibidem, p. 211.
} 
muitos homens que vinham a ela, e em letras de ouro um rótulo ao pé que dizia: CLEMENTIA AD SE HOMINES TRAHIT (A clemência atrai a si os homens)". 515

Para encerrar, observemos a descrição do suntuoso túmulo dos três gentios, que estavam sepultados numa bela sala, adornado e animado por uma sentença sobre a morte (lembre-se que a sentença é a "alma" do emblema, enquanto a imagem é seu “corpo"). Não nos referimos a outros dois emblemas que também tratavam da morte e foram vistos antes pelos personagens, porque este, do túmulo dos gentios, é o mais contundente e sintetiza os dois primeiros. Assim, o ermitão levou Leandro até uma rica sala,

a qual vendo Leandro ficou tão espantado que não sabia donde estava nem se o que via eram cousas da terra, e com rezão, porque esta, como quer que fora feita para sepultura dos três gentios, estava mui estranhamente lavrada de ouro e pedras de muitas várias cores, no meio da qual estavam três cofres sustentados de quatro colunas de prata cada um, em que estavam os ossos dos gentios, os quais mui claramente pareciam por serem de fino cristal, marchetados de ouro, e parte com muitas pedras de diversas cores, e na frontaria de cada um umas letras de esmalte negro que diziam: MORS OMNIA AEQUAT (Tudo a morte acaba e põe por terra). ${ }^{516}$

Como verificamos, na filosofia estóica uma das questões mais debatidas é a morte, e é também um dos pontos principais da doutrina estóico-cristã. Refletir sobre a morte será uma exigência para entendermos melhor a resolução da segunda parte da Constante Florinda. Mas, por enquanto, ressaltemos, como o faz André Chastel, que o "espetáculo" da morte no séuclo XVII ensina, entre outras coisas, como é incerto e frágil o destino humano. ${ }^{517} \mathrm{Em}$ termos estóicos, aprender a viver é aprender a morrer: "uiuere tota uita discendum est et, quod magis fortasse miraberis, tota uita discendum est mori” (De Breuitate Vitae, VII, 3-4). Em termos cristãos, "tudo a morte acaba e põe por terra" parace ecoar o "memento homo, quia pulvis es, et in pulverem reverteris" do Livro de Jó (10:9). Terra, barro ou pó é o começo do homem e também seu fìm. A

\footnotetext{
${ }^{515}$ Idem ibidem, p. 213.

${ }^{516}$ Idem, capítulo XXVI, pp.215-216.

${ }^{517}$ Chastel, A. "Le Baroque et la Mort". In: Retorica e Barocco. Atti del III Congresso Internazionale di Studi Umanistici, op.cit., pp.33-46.
} 
morte a tudo e a todos iguala; ${ }^{518}$ e resta aos vivos adimirar a beleza das sepulturas, que não cansam de lembrar que se morre a cada dia (cotidie morimur).

No capítulo XXXII dos Infortúnios trágicos da Constante Florinda, Leandro, ou melhor, Florinda (pois esta já havia se revelado para salvar a vida) ${ }^{519}$ se encontrava em Nápoles, onde tinha despertado os amores do príncipe Aquilante e, por isso, tinha sido "posta por mandado del-Rei em uma torre com guardas". Mesmo estando a donzela encarcerada na torre, o príncipe Aquilante insistia em tentar conquistá-la e enviava-lhe cartas, porém ele sempre recebia respostas contrárias aos seus desejos. Em tal situação, e depois de já ter tanto sofrido pelo difícil curso de sua vida, Florinda é alçada ao lugar de exemplum da história pelas seguintes palavras do narrador:

Assim esteve Florinda quatro meses sustendo tantos combates, que só o menor deles bastava para derrubar a mais forte e bem murada torre, que se podia achar em um bem fortalecido peito juvenil. Mas como a sua constância e firmeza havia de ser exemplo a todas as que comumente têm pouca, era necessário padecer tantos extremos e perseguições, para que mais se apurasse a fineza dela. ${ }^{520}$

\section{Conforme Curtius,}

Exemplum (paradeigma) é um termo da retórica antiga, a partir de Aristóteles, e significa "história em conserva para exemplo". A isso se juntou (desde cerca de 100 a.C.) uma nova forma de exemplum retórico, que depois se tornou a importante figura de exemplo ou "imagem" (eikon, imago), isto é, "a incorporação de certa qualidade numa figura: Cato ille virtutum viva imago". Cícero (De or., I, § 18) e Quintiliano (XII, 4) recomendam ao orador que tenha à mão exemplos não só da história, como também da mitologia e das lendas heróicas. (...) $\mathrm{Na}$ poesia platônica do século XII encontramos um cânon definitivo dessas

\footnotetext{
${ }^{518}$ São palvras de Sêneca: "Sustine paulum: uenit ecce mors quae uos pares faciat" (De Ira, III, XLIII,1).

${ }^{519}$ Recapitulemos o enredo: quando vivia com o ermitão, Leandro foi raptado por mouros, vendido a uma turca viúva, mas depois resgatado por cristãos e levado para Nápoles. Nesta cidade, tornou-se pajem da princesa Boemunda. Ela acabou se apaixonando por Leandro e, rejeitada, vingou-se do rapaz acusando-o de "traidor", ou seja, de tê-la violentado. O príncipe Aquilante, ouvindo os gritos da esposa e vendo o fingido desespero da mulher, atacou Leandro com um punhal e, quando ia matá-lo, Leandro, na verdade, Florinda "descobriu seus cristalinos peitos" e, assim, salvou sua vida.

${ }^{520}$ Infortúnios trágicos da constante Florinda, capítulo XXXII, p.258.
} 
figuras. Lá elas aparecem como arquétipos, que a sabedoria divina, providente, agregou ao processo histórico. ${ }^{521}$

Para os estóicos, os maiores "exemplos" apenas surgem nos infortúnios: "magnum exemplum nisi mala fortuna non inuenit" (De Prouidentia, III, 4). Talvez por isso tenha sido necessário que Florinda sofresse "tantos extremos e perseguições", pois é somente com tamanhos trabalhos que o sustine et abstine de Epicteto se concretiza e a constância se torna modelo. Como diz Sêneca, o spectaculum de infortúnios, em que um homem valoroso contrapõe-se à má fortuna, é digno de merecer a atenção de um deus: "Ecce spectaculum dignum ad quod respeciat intentus operi suo deus, ecce par deo dignum, uir fortis cum fortuna mala compositus, utique si et prouocauit" (De Prouidentia, II, 9). Florinda, protagonista desse espetáculo, é tão exemplar que por vezes se assemelha a um sábio estóico divino, inacessível aos "estultos", às pobres gentes do "vulgo". Se até mesmo Marco Aurélio, num diálogo patético com sua psyché, acha-se ainda muito distante das qualidades que deveria possuir um perfeito sábio estóico (Meditações, X, 1), os néscios, ante a perfeição de Florinda, é como se olhassem para uma torre de diamante refletindo a luz divina. E é ofício do narrador levantar a torre e torná-la tão atraente de modo que todos desejem nela se encerrar, protegidos contra as investidas das paixões, inimigas versadas na arte de forçar a recta ratio.

Depois que se descobriu que Aquilante continuava com seus amores por Florinda, mesmo estando a donzela presa na torre, o Rei mandou que ela fosse colocada num convento distante de Nápoles. Nesse convento, Florinda reencontrou Gracinda. Assim, esta percebeu o engano que aquela tinha lhe causado quando fingia ser o belo Leandro e, para se vingar, fez com que Florinda fosse expulsa do convento e mandada para a casa de uma "certa dona" amiga da Prioresa. Porém, vendo-se Florinda

posta na boca do mundo, só e desamparada, quis mais tornar-se aos trabalhos dele, do que, esperando seus bens, vivesse arriscada a tantos males; e deixando tudo o que se lhe devia se partiu uma noite sem ser sentida de pessoa de casa, não determinada ir-se a parte alguma certa, senão donde a ventura a guiasse, exposta já de todo aos perigos e contrastes da fortuna, representando a seu entendimento todos os trabalhos e desditas que ao diante lhe podia causar, para que, como

${ }^{521}$ Literatura Européia e Idade Média Latina, op.cit., p.97. 
costumada, não sentisse tanto, quando chegassem, a molestar seu pensamento, porque é bem que um desditoso pondere as desditas antes que venham, porque quando cheguem nenhuma seja nova ao sofrimento. ${ }^{522}$

São várias as lições estóicas que se podem extrair dessas palavras do narrador. Primeiro, é como se nela ecoassem os versos de Virgílio tão caros a Sêneca (Ep. ad Luc., LXXXII, 18): "Tu ne cede malis, sed contra audentior ito / quam tua te fortuna sinet" (Eneida, VI, 95-96). Florinda não cede aos males, mas, corajosa e constantemente, enfrenta-os, como um sábio deve fazê-lo. Além disso, como explica Lípsio no seu De Constantia (III, 7-8), todas as misérias sempre têm uma utilidade: conduzir a algum bem. Portanto, todos os infortúnios são bons pela sua finalidade; porém, por sermos limitados, não podemos conhecer esse fim verdadeiro e só enxergamos o lado ruim das desgraças. Os males que atingem as pessoas virtuosas, como Florinda, têm como causa o amor de Deus, e não Seu ódio, pois tais aflições visam ao bem: elas "provam" os homens bons e ensinam-lhes uma das mais importantes virtudes, a paciência. Na sentença do narrador que encerra o trecho citado ("porque é bem que um desditoso pondere as desditas antes que venham, porque quando cheguem nenhuma seja nova ao sofrimento"), os ecos estóicos estão bastante evidentes. Epicteto, por exemplo, diz que é justamente para isso que serve a filosofa, para nos preparar, com antecedência, contra os infortúnios que recairão sobre nós; trata-se de um verdadeiro "treinamento" (Diatribes, III, 10 e 12; Encheiridon, 29); e quando nos deparamos com uma "impressão externa" (phantasia), não devemos nos deixar levar de imediato por ela, mas temos que dar tempo à reflexão: só assim nos tornaremos mestres de nós mesmos (Encheiridon, 20). Afinal, como afirma Sêneca, “imperare sibi maximum imperium est" (Ep. ad Luc., CXIII, 30).

Por governar a si mesma, com constância, é que Florinda mereceu o prêmio final: reencontrar Arnaldo e, casada e feliz, tornar-se duquesa de Florença. Ela não cedeu às paixões do mundo, como o fizeram os diversos outros personagens que surgiram e narraram suas histórias durante a peregrinação da protagonista. Para ilustrar, lembremos do episódio pastoril, em que Leandro (ainda era "ele") ouviu a história, narrada pelos outros pastores em meio a um locus amoenus, do pastor Arsênio: este

${ }^{522}$ Infortúnios trágicos da constante Florinda, capítulo XXXIII, p.267. 
morrera de ciúmes da bela Luísa; portanto, morreu devido a uma "paixão". 523 Mais exemplar ainda é o caso de Gemilícia, uma peregrina com quem Florinda (já era "ela") se deparou após ter sido expulsa do convento e ter fugido da casa da "certa dona" amiga da Prioresa. Gemilícia é quem conta que, apaixonada ("foi tanta a paixão e tantos os ciúmes"; "foi tão grande a paixão que tomei”) por um "mancebo estrangeiro mercador", matou sua própria aia, "porque me não queria deixar efeituar meu desordenado apetite". Assim, teve que fugir de sua casa e levar uma desafortunada vida peregrina, "pera dar alívio a minhas penas e paixões". 524

Florinda, ao contrário, é o exemplum da virtude desapaixonada, do amor constante. Peregrinou, não para sanar as paixões, mas para não se apaixonar jamais. É o que se depreende das palavras do narrador, já citadas, que concluem os Infortúnios trágicos da constante Florinda:

E esta é a história da firme e constante Florinda, e de seus trágicos infortúnios, os quais não foram bastantes para que lhe fizessem quebrar a palavra e fé que a seu querido Arnaldo dera, antes permanecendo firme e constante veio no fim alcançar o doce fruito deles, acompanhado de tantos bens e alevantada com tanta honra como havemos dito. Donde se pode tirar exemplo que, assim como nossa Florinda, por ser constante e firme em sua palavra e fé, e pela guardar passou tantos trabalhos e infortúnios, no fim dos quais alcançou tão grandes bens desta vida; assim também o que permanecer firme e certo em guardar o que prometeu a Deus e passar trabalhos por satisfazer com a obrigação de sua promessa; esteja certo alcançará os bens da outra, que são a bem-aventurança, na qual permita ele nos vejamos todos pera sempre. Amém. ${ }^{525}$

Como Jó, Florinda padeceu para afirmar a providência divina. A donzela foi estoicamente constante e pacientemente cristã. Foi provada e suportou a provação: os trabalhos pelos quais passou comprovaram a firmeza de sua "palavra" (estóica) e de sua "fé" (cristã). Por isso, foi recompensada com os bens da vida, pois, como disse Lípsio,

\footnotetext{
${ }^{523}$ Idem, capítulo XX.

${ }^{524}$ Idem, capítulo XXXIV.

${ }^{525}$ Idem, capítulo último, p.307.
} 
todos os males visam ao bem. Porém, não é neste teatro do mundo ${ }^{526}$ que se encontra o bem verdadeiro. O narrador, auctor da peça, ensina, enfim, que devemos suportar os infortúnios com uma constância estóica, para que alcancemos a bem-aventurança, isto é, a tranqüilidade cristã que não está neste mundo às avessas, ${ }^{527}$ enganoso mundo feito de pó, mas sim na cidade onde a outra vida ${ }^{528}$ é sempre cristalina.

O desengaño e o desprezo pelos bens desta vida se intensificam na segunda parte da Constante Florinda, na qual, como sabemos, são narrados os infortúnios de Arnaldo em busca de sua amada Florinda. No capítulo V da obra, já se vê uma metáfora marítima representando a falsidade e inconstância da fortuna:

Assim como os que navegam sobre as ondas do mar, que enjoando em um navio, nem por passarem a outro perdem a náusea que os atormenta, porque não nasce do lugar, senão dos ruins humores que em si trazem levantados, assim os tristes e afligidos, ainda que mudem o lugar, nem por isso deixa a fortuna de os perseguir, porque não lhes nascem os males do lugar que deixam, senão da fortuna que contra eles anda levantada. E como é tão falsa e inconstante, nunca costuma dar bem, senão a troco de muitos males, nem um contentamento, senão a peso de muitos desgostos. E se permite algum descanso, é porque, como suas cousas duram pouco, na falta dele seja maior o sentimento de o haver perdido. ${ }^{529}$

Quanto à representação da fortuna através de imagens marítimas, podemos lembrar que no Vocabulário Português e Latino, Bluteau descreve a seguinte figura da Fortuna Pacifica: "Numa medalha de Antonino Pio, cunhada no seu quarto Consulado vemos a figura da Fortuna Pacifica, numa molher, que está em pé sobre o leme de hum navio, com huma cornucopia nas maõs, \& com este letreiro, Fortuna objequens,

\footnotetext{
${ }^{526}$ Sobre a metáfora do mundo como teatro, veja-se Curtius, Literatura Européia e Idade Média Latina, op.cit., 190-196. Maravall considera o "mundo como teatro" a principal tópica do século XVII ( $L a$ cultura del barroco, op.cit., p.320).

${ }^{527}$ V. Curtius, Literatura Européia e Idade Média Latina, op.cit., 139-144; e Maravall, La cultura del barroco, op.cit., p.315 e ss.

${ }^{528}$ Recordemos as palavras de Guillaume du Vair: "Mort, non mort, puis que c'est le commencemẽt de la vraye vie" (De la constance, op.cit., III, p.167) ; ou, ainda, as de Quevedo : "Si no hay otra vida y alma inmortal y Dios, el pecado se queda sin pena y sin juez" ("Providencia de Dios". In: Obras completas, op.cit., p.1560).

${ }^{529}$ Segunda parte da Constante Florinda, capítulo V, p.146.
} 
S.C." ${ }^{530}$ Além disso, no De Constantia de Lípsio, as metáforas mais comumente utilizadas talvez sejam as marítimas. Apenas para exemplificar, vejamos duas delas (são muitas outras ao longo de todo o tratado). Na primeira, a "Necessidade" (Necessitas) das coisas humanas é comparada aos rios que desembocam, obrigatoriamente, no mar: "Atque ut flumina ad mare feruntur, perpeti et prono cursu: sic res omnes humanae per hunc (ut sic dicam) cladium canalem labuntur ad suam metam" (De Constantia, I, 15). ${ }^{531} \mathrm{Na}$ segunda, fala-se do livre-arbítrio, que permite ao homem lutar contra as disposições divinas, sem, no entanto, jamais vencê-las ou impedi-las. Assim, a liberdade humana é como o tripulante que pode se movimentar à vontade no navio, mas que não tem o poder de alterar seu curso:

Ut in navi ambulare mihi fas, et per foros discurrere aut transtra sed nihil minutus hic motus valet ut impediat ejus cursum: sic in fatali haec navi qua omnes vehimur, currant licet voluntates nostrae et transcurrant, non via eam ejicient aut sistent. Temperabit et habenas moderabitur semper suprema illa voluntas: et quo visum erit cumque, currum hunc diriget leni quodam fraeno (De Constantia, I, 20). ${ }^{532}$

Vale ressaltar também que há uma semelhança de idéias entre o mencionado trecho da segunda parte da Constante Florinda e o intento último do De Constantia de Lípsio, que é exposto logo nos primeiros capítulos do tratado. O narrador da Constante Florinda afirma que não adianta que os "tristes e afligidos" mudem de lugar, porque seus males não nascem dos lugares e sim da sua "fortuna". De modo semelhante, no início do De Constantia, Langius explica a Lipsius que não se deve fugir dos países e sim das "paixões", já que estas não são sanadas pelas viagens: não há como fugir de si mesmo. Em suma, viajar não cura as "doenças da alma", antes, renova-as e intensificaas; o único e verdadeiro remédio é a constância, que se adquire pela sapiência ( $D e$ Constantia, I, 1-3). Seja contra a fortuna ou contra as paixões, mudar simplesmente de lugar jamais será o remédio: Sêneca já dizia que as "peregrinações" são inúteis, ou

\footnotetext{
${ }^{530}$ Vocabulario Portuguez, \& Latino, op.cit., verb. "Fortuna".

531 Citamos o texto latino a partir da edição de Jacqueline Lagrée, Juste Lipse et la Restauration du Stö̈cisme, op.cit., p.132.

${ }^{532}$ Idem, p.152. "Assim como num navio posso andar e percorrer, em todos os sentidos, seus conveses e seus corredores estreitos sem que esse pequeno movimento impeça em nada seu curso, do mesmo modo, no navio do destino que carrega a todos nós, embora nossas vontades corram e transcorram, não conseguirão parar ou desviar a rota. A vontade suprema temperará sempre e controlará as rédeas, e ela dirigirá essa carruagem na direção prevista, sem usar o freio" (tradução minha).
} 
melhor, são obstáculos à sabedoria, pois, como aconselha, "animum debes mutare, non caelum" (Ep. ad Luc., XXVIII, 1).

Como afirmamos anteriormente, na narração da segunda parte da Constante Florinda fica bastante evidente o tom desolador ou desenganado, mais do que na primeira parte. Sabemos que a história dos infortúnios de Arnaldo começa com uma cena de caça, cujo protagonista, um misterioso caçador, ${ }^{533}$ é o foco central da narração nos primeiros capítulos. Depois de se envolver na contenda da torre e matar um dos homens que tinham invadido o local (capítulo IV), o caçador acaba sendo preso. Na prisão, conhece um rapaz que também estava ali encarcerado. Antes que esse preso dê conta de sua desfortunada vida, ${ }^{534}$ o narrador faz um preâmbulo, refletindo sobre os enganos não só daquela vida que será relatada, mas da condição humana em geral:

Sempre a esperança de viver fez parecer a vida larga, sendo assim que é breve a quem passa entre gostos e contentamentos, porque a este todo o passado lhe parece breve, e só o que está por vir lhe dá pena, porque imagina que tarda. Porém, o que passa a vida com trabalhos, os que vai deixando the parecem largos, e os que espera the parecem grandes, porque quem tem os males por certos, antes que cheguem já os padece. E daqui vem que muitos se satisfazem mais com a morte, porque quem vive vida desesperada, só com a morte se contenta (grifos nossos). ${ }^{535}$

Alguns aspectos desse trecho podem ser destacados. O narrador, como persona que demonstra um ethos estóico, tende a atribuir a origem dos males à "opinião" (doxa, opinio): "fez parecer", "lhe parece", “imagina”, "lhe parecem", "lhe parecem”. Como explica Du Vair, na Philosophie morale des stö̈ques, os sentidos, enganados pela "aparência" (apparence), perturbam ou tumultuam nossa alma, não permitindo que a razão seja ouvida nem o entendimento obedecido. ${ }^{536}$ E é justamente dessa fausse opinion que nascem as paixões. ${ }^{537} \mathrm{Na}$ doutrina estóica, como vimos em Diógenes Laércio, são quatro as principais paixões, sendo o medo uma delas. Este tem por objeto um mal futuro, ou seja, aquele mal que nem mesmo sabemos se irá realmente

\footnotetext{
${ }^{533}$ Embora tenha começado a contar os detalhes de sua vida no capítulo III, o caçador, cujo nome é Flamiano, só conseguirá retomar seu relato no capítulo XVIII e terminar sua história no capítulo XIX.

${ }^{534}$ Vale destacar que o preso é um dos homens que invadiram a torre e com os quais o caçador havia lutado.

${ }_{535}$ Segunda parte da Constante Florinda, capítulo VI, pp.148-149.

${ }_{536}^{536}$ Philosophie morale des stö̈ques, op.cit., p.70.

${ }^{537}$ Idem, p.72.
} 
nos atingir. Somente a "falsa opinião" (que atormenta mais do que a própria coisa) pode tornar esses males futuros certos, ignorando a razão e causando um sofrimento antecipado. Para quem leva uma vida assim desesperada, satisfazer-se com a morte é também uma paixão, já que a morte, em termos estóico-cristãos, não deve ser desejada (nem temida), embora ponha fim à miseria hominis. Ao contrário, o sábio estóicocristão deve demonstrar firmeza no sofrer, pois a esperança (e não a "opinião") lhe ensina a confiar na providência divina.

Retomemos algumas peripécias da história, já referidas, para que se compreenda melhor a narração e, conseqüentemente, os procedimentos da persona que narra. Da prisão, o caçador foi mandado para um degredo de três anos em Mallorca. Porém, o navio que o conduzia ao degredo foi saqueado e o caçador ("a quem a fortuna perseguia") acabou se tornando cativo dos mouros. Assim, foi levado para a cidade de Tagda, onde passou a ser empregado de um mouro (cujo nome era Hamete). Em Tagda, foi que, ao conversar com um cativo, o caçador percebeu que se tratava daquele mesmo mancebo que encontrara na torre, onde se originaram os males do "triste caçador" que o levaram àquela primeira prisão e o tinham trazido a Tagda. Mais ainda: só então é que se revela quem era o mancebo, o constante Arnaldo em busca de sua amada Florinda. Porém, antes que o "cativo" (que só depois saberemos ser Arnaldo) comece seu relato, sentencia o narrador: "Sempre o ânimo generoso, criado em a frágua do trabalho, pôs em a casa de sua esperança os penhores do prémio que promete a quem com firmeza o sofrer". 538

Em seu tratado Providencia de Dios, Quevedo parece tentar restringir sua argumentação à doutrina cristã. Mas, mesmo assim, Sêneca não deixa de ser uma de suas principais fontes, ainda que seja para provar que Deus existe e é providente, e que a alma é imortal. Por isso, tal escrito de Quevedo, predominantemente cristão, pode nos ajudar a entender aquela sentença do narrador, na qual também preponderam noções cristãs, em particular, a de "esperança". Observemos, então, um trecho de Quevedo:

Con esta respuesta satisfizo Dios em Habuc a todos: "Lo que se ha de ver está lejos; mas veráse al fin y no mentirá. Si se tardare, esperálo, porque vendrá a toda prisa y no se detendrá". En estas cosas no es lo que se ve lo que se admira en las felicidades, sino lo que se ve lo que se manifesta al fin. Esto lejos está a nuestra impaciencia, tárdase a nuestro

\footnotetext{
${ }^{538}$ Segunda parte da Constante Florinda, capítulo XIV, p.170.
} 
deseo; y no se detiene, y camina a toda prisa las jornadas que le destina la tolerancia de la divina Providencia. ${ }^{539}$

Só têm paciência aqueles que acreditam na Providência e que, portanto, são firmes. Esses podem esperar, pois seu prêmio está guardado por Deus. Os infortúnios pelos quais passam fortalecem o ânimo, "porque las calamidades dan mejor cuenta del seso humano que la prosperidad". ${ }^{440}$ É preciso crer, sempre, na promessa divina, mesmo que na vida apenas se veja a miséria. Tudo que o homem possui é sua esperança numa melhor vida, que decorrerá da imortalidade da alma. Por isso, há de se ter firmeza e paciência, para que, no final, possam ser resgatados os penhores tão esperados. Enfim, assevera Quevedo: "Nada posee quien no posee su alma. Todos tienen alma y sólo la poseen los que tienen paciencia". E continua: "Solos aquellos que saben padecer lo que tienen, poseen sus almas en su paciencia, y con ella poseen todo". ${ }^{541}$ Para se possuir a própria alma, é necessário paciência; para se ter paciência, é preciso sofrer.

E é de constância, infortúnios e impaciência que se constituem as histórias de Florinda e Arnaldo e dos demais personagens; todos, em certa medida, julgados pelas palavras do narrador. E, considerado a maior firmeza dos protagonistas, é o seu amor. Diante da proposta que a moura Fátima fez a Arnaldo, caso este cedesse aos desejos daquela, de dar liberdade a ele, ao caçador (Flamiano) e à cativa, antes mesmo da resposta do rapaz, julga o narrador a firmeza do amor de Arnaldo por Florinda:

Ao lanço deste oferecimento se lançou a Cativa, porque tinha aplicado o sentido ao que Fátima passava com Arnaldo, e como desejosa de sua liberdade, aprovou o que a Moura dezia, persuadindo a Arnaldo que aceitasse aquela palavra, pois the trazia o remédio que os podia livrar de seu cativeiro, a quem Flamiano ajudava com outras razões tão eficazes que podiam render a qualquer peito, quando não estivera fortalecido de tão firme amor, qual era o que tinha à sua ausente Florinda, cuja vista era nesta ocasião tão desejada, como a de Penélope de Ulisses quando estava em sua ausência, para que visse os combates que sofria sua firmeza, pois era conquistada de tão fortes inimigos, como são lágrimas de mulher afeiçoada, certeza de liberdade, e rogos

\footnotetext{
${ }^{539}$ Obras completas, op.cit., p.1599.

540 Idem, p. 1597.

${ }^{541}$ Idem, p. 1600.
} 
de amigos interessados, que fazem força aos corações mais duros; e na verdade, esta foi uma das ocasiões em que Arnaldo mostrou a fineza do amor que tinha a sua amada Florinda, e tanto era maior, quanto mais incerteza tinha de sua vida e mais desterrado estava de sua presença; porque amar à vista não é muito, porque o objecto da cousa amada sempre move a potência de quem ama; porém guardar fé em ausência é cousa mais dificultosa, e frágua aonde o amor descobre os quilates de sua firmeza. ${ }^{542}$

É o próprio Arnaldo que responde à proposta da moura: "não é bem que me obrigue, oferecendo o amor a troco de liberdade". Nada está acima do amor que o rapaz devota a Florinda, nem mesmo a liberdade ou a amizade. Mas amor tão forte já não seria paixão? A essa questão o narrador responderá no final da obra. Por enquanto, ressaltemos que os estóico-cristãos, embora critiquem a apatheia, não defendem as paixões. A ação do sábio estóico ou do bom cristão é avaliada, em ultíma instância, com base nas virtudes. Para o amor de Arnaldo e Florinda, lembremos, especialmente, da definição que Charron dá à temperança:

La temperance a donc pour son sujet et objet general toute prosperité, chose plaisante et plausible, mais specialement et proprement la volupté, de laquelle elle est retranchement et reglement, retranchement de la superflue estrangere, vitieuse; Reglement de la naturelle et necessaire (...). C'est l'authorité et puissance de la raison sur les cupidités et violentes affections, qui portent nos volontés aux plaisirs et voluptés. Cest le frein de nostre ame, et l'instrument propre à escumer les boüillons, qui s'eslevent par la chaleur et intemperance du sang, afin de contenir l'ame une, et égale à la raison, afin qu'elle ne s'accommode point auxs objects sensibles: mais plustot qu'elle les accommode et face servir à soy. ${ }^{543}$

Arnaldo parece usar o "freio da alma" para todas as coisas, com exceção de seu próprio amor, cujo limite é a sua plena satisfação. Ele ama como quem serve e não como quem se governa pela razão. Acima de todas as coisas, deveria estar somente o amor a Deus;

\footnotetext{
${ }^{542}$ Segunda parte da Constante Florinda, capítulo XX, pp.188-189.

${ }^{543}$ De la sagesse, op.cit., pp.779-780.
} 
no entanto, Florinda é a Prudência no reino amoroso do rapaz. ${ }^{544}$ Este age prudentemente, mas seu escudo ${ }^{545}$ é sua amada Florinda, que, embora ausente, é objeto sempre presente na firmeza e constância de Arnaldo.

No entanto, isso ficará mais evidente apenas no último capítulo da obra, no qual se faz um julgamento final dos protagonistas e de seu amor. Durante a maior parte da narração, o que se percebe mesmo é um elogio à virtude estóico-cristã de Arnaldo. Por recusar os oferecimentos de Fátima, Arnaldo e seus amigos continuaram cativos na casa do mouro Hamete. Na ausência de seu pai, Fátima "enterrou em a prisão ao nosso perseguido Arnaldo" e se entregou aos amores de seu primo Rodante. Quando Hamete voltou de viagem, descobriu o "delito" de Rodante, mas este imputou toda a culpa a Arnaldo, que acabou sendo condenado ao fogo. Ainda que inocente, o amado de Florinda, como um verdadeiro herói estóico-cristão, se oferece bravamente ao suplício do fogo com as seguintes palavras (que são uma perfeita síntese do caráter do rapaz):

Já agora, fortuna inimiga, estarás contente, pois tuas perseguições puderam tanto, que obraram o que quiseste, e a mim chegaram a tão infelice estado, que cedo porão fim a meus dias os rigores de um tormento; porém erraste em ordenar que fosse de fogo, que quem com o mal se cria, vem a não sentir em ele alguma pena; e como sempre me sustentei com o fogo de amor, nunca seria perfeita tua vingança, quanto mais que não receo a morte, pois dou a vida por guardar a firmeza, e sem haver cometido culpa contra o bem que adoro em ausência, em cujo alcance determinava de gastar a vida. E pois é forçado que a perca, necessário é que sinta a falta que fez a meus olhos, quem eles já viram, pera me pedir, e agora não vem para me despedir. E se na força de meus males o cuidar por quem os padecia me servia de glória, forçado é que leve saudades deles, e já com a lembrança de os perder, sinto dobrado mal. Esta fé e o amor verdadeiro que em mim tendes experimentado, quero, amigos meus, que me presenteis ao refúgio de meu cuidado, se acaso o encontrardes em algum tempo; e ainda que esta diligência não aproveite para me dar vida, ao menos servirá de sentir menos a morte. E pois à nossa amizade, sendo como era tão

\footnotetext{
${ }^{544}$ Não nos esqueçamos que Charron considera a Prudência como a Rainha de todas as outras virtudes (Idem, p.545).

${ }^{545}$ É Du Vair que compara a Prudência ao escudo de Aquiles (Philosophie morale des stö̈ques, op.cit., p.69).
} 
verdadeira, se não pode dar o galardão que merece, peço-vos que aceiteis em satisfação o desejo que de mim conheceis, que tinha para a satisfazer. E com isto ficai-vos, a Deus, que ele vos livre, para que não venhais a ser arguídos de outra falsidade, que eu me parto desta vida, deixando nela a melhor prenda que guardava na alma. ${ }^{546}$

Se não bastasse esse amor estar acima da liberdade e da amizade, está também muito acima da própria vida. Diante de tal atitude e, principalmente, em virtude de tais palavras de Arnaldo, prenuncia o narrador: "o alto Deus nunca falta a quem nele confia, e em o maior trabalho costuma acudir ao afligido". Assim, moveu-se o coração de Rodante e confessou sua culpa, inocentando o afligido amado de Florinda. E, conseqüentemente, veio o prêmio divino: "Ficou Hamete admirado com esta confissão do Mouro, considerando por uma parte a traição que lhe fizera, por outra a paciência com que Arnaldo se oferecia ao tormento sem estar culpado, ao qual mandou logo tirar da prisão com grande contentamento dos dous cativos". ${ }^{547}$ Arnaldo é um típico sábio estóico-cristão, que com sua paciência enfrenta todos os males, mesmo que seja inocente, porque confia na Providência divina. Aproxima-se da figura de um mártir cristão, que, mais do que um ser "mágico", é um exemplum, um modelo de vida a ser seguido. ${ }^{548}$ Mas, como ficou claro nas próprias palavras do herói, o motor de sua santidade é o amor que devota a Florinda. Esse exagero ou excesso amoroso, comum entre os amantes, é também denunciado, talvez já justificando o que ocorrerá no fim da história: "Ainda que não haja tempo mais perdido que aquele que se gasta com os cuidados do mundo, contudo é próprio de um amante parecer-lhe que é tempo mal gastado aquele em que seu cuidado amoroso comete algum descuido". 549

No já mencionado episódio em que Arnaldo, quando estava na França, se deparou com umas "casas subterrâneas", nas quais vivia um "triste queixoso" (Laureano) que lhe mostrou as pinturas exemplares, lembremos de uma das sentenças que adornam a pintura da Virtude: "Não é Virtude não poder cometer pecado, senão

\footnotetext{
${ }^{546}$ Segunda parte da Constante Florinda, capítulo XXIII, p.197.

${ }^{547}$ Idem ibidem, p. 198.

${ }^{548}$ É o que afirma Jean-Yves Tilliete sobre a função dos santos: "Il est bien évident que la sainteté chrétienne (...) ne se réduit pas à cette dimension magique. Le saint n'est pas (pas seulement) un medium, une force indifférenciée, un passeur entre les deux rivages du monde. Il est d'abord un individu"; "Il faudrait parler ici de la fonction des saints comme modèles, cette fois au sens d'exemples à suivre, moteurs de conversions individuelles" ("Introduction". In: Les fonctions des saints dans le monde occidental (III ${ }^{e}$-XIII $e^{e}$ siècle). Actes du colloque organisé par l'École française de Rome avec le concours de l'Université de Rome «La Sapienza ». Roma : École Française de Rome, 1991, pp.5-6).

${ }^{549}$ Segunda parte da Constante Florinda, capítulo XXVII, p.208.
} 
saber-se abster do vicío". ${ }^{550}$ Como sabemos, uma conduta virtuosa, para Epicteto, resume-se ao Sustine et Abstine. A sentença da pintura coloca em primeiro plano a importância da "abstenção": como diz Epicteto, é preciso negligenciar as coisas externas para que se mantenha o "propósito moral” (Encheiridon, 13); esse é o caminho que conduz à virtude e pelo qual se afasta o vício.

Uma outra pintura exemplar merece ser destacada, aquela em que é representado o "Amor":

Em ũa das frontarias da sala estava pintado o AMOR, desta maneira: posto em um carro, pelo qual tiravam quatro cavalos a toda pressa. E entre eles ũas letras, que deziam desta maneira: $O$ Amor não se sujeita a conselho, nem se refreia com a vergonha, nem se aplaca com a razão. Tinha o rosto corado, à vista de ũa mulher que tinha diante de si, com esta letra: Envergonha-se o Amor com a dificuldade. Vinha despojado do vestido, com uma letra que dezia: De liberal não tem que vestir. Em uma mão tinha um arco e na outra uma chama de fogo, e entre elas umas letras nesta maneira: $O$ que escapa da seta vai morrer em a chama. Cingia espada e tinha asas em os pés, com esta letra: Para os fortes, armas, para os ligeiros asas. Estava posto entre Hércules, que foi de muitas obras, e o Deus Mercúrio, que era Deus da Eloquiência, e em roda estas letras: Para ser verdadeiro, há-de ter mais de Hércules que de Mercúrio. ${ }^{551}$

O que sobressai nessa pintura é o poder absoluto do amor: ele não se aplaca nem mesmo com a razão, diz a primeira sentença. Como observamos nas nossas análises, em vários textos da filosofia estóica (especialmente em Sêneca), e também da doutrina estóicocristã (em particular Justo Lípsio), a uirtus é identificada com a recta ratio. Aquele que não se guia pela razão não é um sapiens, mas um stultus; é alguém que, por exemplo, de tão liberal fica sem ter o que vestir. E a pintura, descrita pelo narrador, parace querer mostrar justamente que o Amor, irrefreável, torna os homens "estultos"; se ele ignora a razão e perturba o "ânimo", ou melhor, a "alma", trata-se, portanto, de uma típica paixão. Para não restar dúvida, vejamos como nascem as paixões, seguindo a explicação

\footnotetext{
${ }^{550}$ Idem, capítulo XXXII, p.224.

${ }^{551}$ Idem ibidem, p. 225.
} 
de Sêneca em seu tratado que é uma das principais fontes antigas sobre o tema, o $D e$ Ira:

\begin{abstract}
Et ut scias quemadmodum incipiant adfectus aut crescant aut efferantur, est primus motus non uoluntarius, quasi praeparatio adfectus et quaedam comminatio; alter cum uoluntate non contumaci, tamquam oporteat me uindicari cum laesus sim, aut oporteat hunc poenas dare cum scelus fecerit; tertius motus est iam inpotens, qui non si oportet ulcisci uult sed utique, qui rationem euicit. (De Ira, II, IV, 1).
\end{abstract}

No nascimento do adfectus, há primeiro um movimento involuntário, uma espécie de preparação da "paixão"; depois, um segundo movimento que, embora voluntário, não é contumaz; por fim, surge o terceiro movimento que, totalmente desordenado, vence a razão. A razão vencida, não cabe mais o discurso: talvez por isso o amor, ainda que verdadeiro, não possa contar com Mercúrio, pois, como Hércules, é pura força. É, enfim, como a ira, um impetus que ultrapassa a razão e a carrega consigo ("illa est ira quae rationem transsilit, quae secum rapit"). ${ }^{552}$

Após deixar aquele lugar onde Laureano morava, Arnaldo envolveu-se numa briga para socorrer uma donzela e acabou sendo preso pela "justiça". Na prisão, ocorreram engenhosos "reconhecimentos" (Fabrício era o irmão de Flamiano e Altíbia, a moça a quem Arnaldo tinha socorrido, era, na verdade, Polidora) e, depois de esclarecidos os fatos, a justiça decidiu libertar o amado de Florinda. Pouco antes de o rapaz ser libertado, sentencia o narrador: "Muitos são condenados no juízo humano que estão sem culpa em o Juízo Divino”. Em liberdade, “logo Arnaldo se partiu deste lugar, considerando como esta vida era um bosque de espinhos, e como seus bens eram falsos, e seus males verdadeiros, suas esperanças vãs, suas alegrias fingidas e suas tristezas certas". ${ }^{553}$ Em tais palavras, ressaltam-se a ignorância humana ante a presciência divina e o desengaño do mundo. Por este bosque de espinhos também passou Jó, que foi condenado por seus "amigos", embora fosse inocente perante Deus. Não só Arnaldo e Jó passaram por isso, Deus, feito homem, também padeceu, sem culpa, os infortúnios deste mundo, como afirma Quevedo: "Pobreza, persecución, afrentas, traición, calumnias, falsos testemonios, tormentos, prisión, por si sabe Dios (que las padeció

\footnotetext{
${ }^{552}$ De Ira, II, III, 4.

${ }^{553}$ Segunda parte da Constante Florinda, capítulo XXXIV, pp.231 e 232.
} 
hecho hombre, con muerte afrentosa) que no sólo caben en el inocente y santo, sino en el tres veces santo, que ni pecó ni pudo pecar". 554

Essas misérias da vida ficam ainda mais evidentes nas histórias dos personagens que entrecruzam o enredo principal. São muitos os nomes e episódios que vão surgindo ao longo da peregrinação de Arnaldo. E o mais curioso é que, nesta segunda parte, reaparecem personagens da primeira que dão notícias do rumo que tomou Florinda (como é o caso de Artêmia, que conversa com Arnaldo no capítulo XXXVI). Nessas histórias secundárias só é constante a tragédia, sempre causada pelas paixões incontidas. Os infortúnios pelos quais passam tais personagens ensinam que os vícios hão de ser castigados e acentuam, paradoxalmente, a confusão do mundo, paradoxal e confuso para o limitado conhecimento humano, mas não para a Providência divina.

Para exemplificar, vale a pena mencionar um desses vários episódios repletos de paixões, enganos e tragédias. Arnaldo, chegando a Gênova, tentou ajudar uma pastora que estava sendo atacada por dois homens e colocou-se em grande perigo; quando iam ser mortos, ele e a pastora foram salvos por um velho, que espantou aqueles homens apenas com suas duras palavras. O velho, então, passou a contar sua história para Arnaldo. Chamava-se Aldrâmio, foi capitão, ficou viúvo aos trinta anos, sendo que a morte da esposa foi causada pelo desaparecimento de sua filha de três anos, perdida por um descuido da ama que criava a menina e que teria deixado-a cair em um poço. Um dia, passeando por uma floresta, Aldrâmio ouviu, à beira de um rio, uma criança recém-nascida chorar. Seguindo o choro, encontrou a criança e a mãe, Lauriélea, que tinha dado à luz entre uns penedos. Aldrâmio acolheu Lauriélea em sua casa e acabou se casando com a moça. "Porém como as cousas da fortuna, ainda na maior força de sua

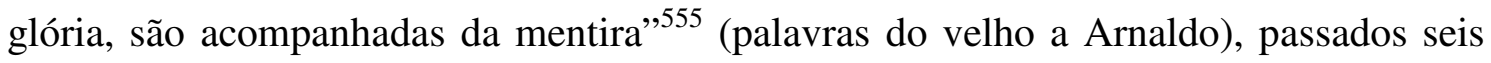
meses desse casamento, o filho de Aldrâmio, chamado Célio, que estava viajando "em guerras”, retornou à casa do pai. Num reconhecimento trágico, descobre-se, então, que Célio era o pai do menino que Lauriélea tinha dado à luz entre os penedos. Aldrâmio, depois que se viu enganado, mandou matar seu próprio filho, que escapou com a ajuda de Lauriélea. Esta estava grávida de Aldrâmio, que, por isso, não conseguiu se "ausentar pelo mundo desconhecido", 556 ainda que esse fosse seu desejo. Os lanços trágicos de tal

\footnotetext{
${ }^{554}$ La constancia y paciencia del santo Job. In: Obras completas, op.cit., p.1512.

${ }_{555}$ Segunda parte da Constante Florinda, capítulo XXXIX, p.246.

${ }^{556}$ Idem ibidem, p. 247.
} 
história se intensificaram ainda mais. Um certo dia, uma velha foi à casa de Aldrâmio para falar com Lauriélea. A velha era Pasifa, suposta tia que criara a moça. Eis o que Pasifa foi ali fazer, segundo as palavras do próprio Aldrâmio:

descobriu como Lauriélea era minha filha verdadeira, a qual mandara furtar do jardim em o tempo que julgámos que caíra no poço, com intento de lhe ensinar sua arte e criar como filha, pois nunca tivera outro estado, e assim a criara com o título de sobrinha sua, com o amor e respeito que ela tinha experimentado, até o tempo que fugira de sua casa. E porque tivera notícia do que lhe tinha sucedido, e como estava casada comigo em Génova, vinha descarregar sua consciência exposta a todo o castigo que estava merecendo. Como quem entendia ser melhor dar-se ao corpo, do que chegar a tempo, em que se executasse na alma. ${ }^{557}$

Ou seja, Lauriélea era a irmã supostamente desaparecida de Célio e, ao mesmo tempo, mãe de seu filho (Flávio), que era neto de Aldrâmio. Se não bastasse isso, a moça era também esposa de Aldrâmio (seu pai), com quem teve uma filha chamada, curiosamente, Felizarda. Fica-se sabendo, finalmente, que Célio morreu na guerra e Lauriélea entrou para o convento. Mais ainda: quem queria matar aquela pastora que Arnaldo tentou ajudar foi justamente Flávio, o neto-enteado do velho. Mas a história de Flávio e da pastora (Cassandra) já é uma outra trágica "confusão”, que não cabe aqui deslindar.

No relato de Aldrâmio, que é uma boa amostra dos demais episódios, é patente a "loucura do mundo" ou o "mundo como labirinto confuso". 558 Os personagens se perdem o tempo todo entre tantos enganos e paixões. Como numa típica tragédia antiga, nada podem fazer frente ao Fatum. Ou melhor, como numa típica tragédia cristã, nada podem compreender dos desígnios de Deus, que, providencialmente, ordena todas as coisas. Enfim, numa perspectiva como essa, o homem é o sonho de uma sombra, para retomar um conhecido verso de Píndaro, citado, por exemplo, por Lípsio ( $D e$ Constantia, I, 17).

\footnotetext{
${ }^{557}$ Idem ibidem, p. 247.

${ }^{558}$ Com relação a essas tópicas seiscentistas, veja-se Maravall, La cultura del barroco, op.cit., pp.312 e ss.
} 
No entanto, resta a esperança para aqueles que se mantêm firmes, constantes e pacientes; como Arnaldo, que depois de tanto peregrinar e suportar recebeu seu devido galardão, "porque se vinha já chegando o tempo em que a firmeza de seu amor havia de ser apremeada com a que merecia", 559 reencontrando, assim, sua amada Florinda e tornando-se duque em Florença. Como sabemos, aqui se encerrou a primeira parte da obra; a segunda vai além e dá conta do que aconteceu aos amantes em Florença. Apesar de já termos relatado, vale a pena referir mais uma vez para reanimar a memória. Em Florença, Arnaldo e Florinda viviam felizes como duque e duquesa, até que Aquilante, então rei de Nápoles, atacou o território florentino apenas para se vingar de Florinda, que tinha rejeitado seus amores. Assim, conquistando Florença, Aquilante condena os dois amantes à morte. Arnaldo é degolado publicamente e Florinda nem chega sofrer o suplício, pois, não suportando a dor da perda de seu amado, morre, subitamente, logo em seguida. Repitamos, portanto, as palavras do narrador que encerram o texto e que julgam, em última instância, os pensamentos e as ações de Arnaldo e Florinda:

E este é o fim que tiveram estes dous amantes tão firmes. Estes foram seus trágicos infortúnios. Nisto vieram a parar tantos dons da natureza. Este foi o prémio que teve o desordenado amor da mocidade. E se eles foram firmes às glórias da vida, não tiveram firmeza. Esta verdade nos está ensinando, que tragamos sempre em a memória escritas estas palavras:

Para que são glórias, nem honras da vida, se mais perde quem mais alcança. ${ }^{560}$

Como vimos, para os estóicos, as paixões são doenças ou afecções da psyché ou do animus; para os estóico-cristãos, são doenças da alma. O verdadeiro sábio é aquele que não é tomado por tais paixões; é aquele que vive na constância da razão e não na turbulência dos afetos. Um sábio jamais deve agir guiado pela dor, pelo medo, pela concupiscência ou pelo prazer; seu único piloto é a razão (logos, ratio). E é racionalmente que ele deve amar. Este amor virtuoso lembra a agape de que fala Paulo $^{561}$ na primeira epístola aos Coríntios: paciente e que tudo desculpa, tudo crê, tudo

\footnotetext{
${ }_{559}^{550}$ Segunda parte da Constante Florinda, capítulo XLV, p.263.

${ }^{560}$ Idem, capítulo último, p.269.

${ }^{561}$ Vale ressaltar, a propósito, que o mito da amizade e da troca de correpondência entre Sêneca e São Paulo era ainda bastante divulgado no século XVII, como explica Blüher: "Es cierto que el Humanismo y, en particular, Erasmo habían terminado con el mito de la amistad de Séneca con San Pablo, mito que
} 
espera, tudo suporta (I Coríntios, 13, 1-7). A paixão, ao contrário, é impaciente e viciosa, como o pecado.

Na primeira parte da Constante Florinda, a heroína viajou para defender o amor contra as paixões do mundo. Por isso, teve sua recompensa (o reencontro e o casamento com seu amado). Na segunda parte, foi a vez de Arnaldo peregrinar, e também se mostrou um exemplo de virtude. Entretanto, por que afirma o narrador que se aqueles amantes "foram firmes às glórias da vida, não tiveram firmeza"? Segundo a doutrina cristã, o homem, desde o pecado original, está condenado. ${ }^{562}$ Sua punição é ser sempre apenas um reflexo da perfeição divina, sem jamais alcançá-la; sempre dividido, o ser humano só vê por espelho e apenas conhece em parte (I Coríntios, 13, 12). Daí ser seu amor mero reflexo do amor divino ou, estoicizando a doutrina, da virtude de um sábio perfeito (que também se assemelha a uma divindade inatingível). O amor humano é imperfeito, é apenas paixão, porque ao homem ainda não é permitido ver face a face nem conhecer totalmente as coisas como ele mesmo é conhecido por Deus (I Coríntios, $13,12)$. O "desordenado amor da mocidade" (de que fala o narrador) é o máximo que Florinda e Arnaldo, dois grandes exemplos de virtude, poderiam oferecer, mas não é o bastante. A história desses amantes, ou melhor, desses apaixonados é, em termos retórico-poéticos, deleite, mas também é ensinamento, e está a nos ensinar, numa perspectiva estóico-cristã, que devemos recusar os bens da vida para receber o único e verdadeiro Bem: aquele que nos aguarda após a morte.

Nesse sentido, conclui Du Vair seu tratado De la sainte philosophie:

Mais puisque cette dernière et plus parfaite félicité consiste au regard de la face du Père des lumières, en laquelle nous verrons la source et origine de toute bonté et beauté, et qu'il ne veut pas que, tant que nous serons enveloppés ès ténèbres du monde, nous le voyons face à face mais seulement par derrière et comme en passant, nous nous tairons, et admirerons en silence ce que nous savons être, mais ne savons pas comment, ce dont nous ne pouvons parler, sinon accusant

había documentado la posición de Séneca ante el cristianismo en el Medievo. Como hemos visto, durante el siglo XVI España siguió, en la mayoíria de las obras, la opinión de Erasmo. Abundan las indicaciones de que esa invención estaba a punto de disiparse. Es, pues, tanto más asombroso que vuelva a surgir en el siglo XVII, renovada y con más vitalidad que antes" (Séneca en España, op.cit., p.362). Assim, acreditar nessa suposta amizade é aceitar que há uma afinidade entre estóicos e cristãos e, conseqüentemente, entre as suas doutrinas.

${ }^{562}$ Lembremos da condenação de Adão e Eva em Gênesis, 3, 14-24. Vale a pena recordar também as palavras de Quevedo em De los remedios de cualquier fortuna: "Después que el pecado enfermó la naturaleza, mi propria es enferma, y yo soy una enfermedad viva” (Obras completas, op.cit., p.1074). 
notre ignorance, ce dont nous ne pouvons rien affermer, sinon que ce n'est rien de ce que nous connaissons par les sens, mais chose qui surpasse sans mesure toute autre perfection : nos sens ne peuvent percer jusque-là, et notre esprit rebouche, plus il s'efforce d'y pénetrer.

Que nous reste-il donc? L'espérance très certaine que, si nous nous contenons purs et nets en ce monde et nous rendons dignes de la grâce et amitié que notre Père céleste nous offre, ne détournant point nos affections et l'honneur que nous lui devons aux choses terrestres et mondaines, nous entrerons un jour, comme ses enfants et héritiers de sa glorie, au trésor de ses richesses célestes et jouirons, suivant ses promesses, de la splendeur de son éternité. ${ }^{563}$

Florinda e Arnaldo não poderiam se amar perfeitamente, pois estavam envolvidos pelas "trevas do mundo". Como todos os seres do gênero humano, eles se apaixonaram e viveram seguindo sua paixão. E o narrador, como persona que imita um sábio estóico-cristão, não haveria de fazer outra coisa senão condená-los. Abster-se dos bens da vida é a única forma de alcançar o bem da morte. Se aqueles amantes alcançaram ou não este bem, nem o narrador pode nos dizer, pois a ignorância humana jamais conhecerá plenamente a Providência divina. Com suas palavras, o narrador pode nos conduzir apenas até os limites da vida, e mesmo nesta só é possível admirar em silêncio o que, embora saibamos ser, não sabemos como é, aquilo de que não podemos falar a não ser para expor a nossa própria ignorância.

Nesta vida, tudo é engano ou sonho, ${ }^{564}$ sombra da outra vida, somente ela segura e verdadeira. A doutrina estóico-cristã restringe-se à conduta dos vivos; Deus, e apenas Ele, saberá o que fazer com as almas dos mortos. E conduzir-se bem, segundo tal doutrina, é suportar os infortúnios recusando as glórias e as honras, falsos remédios que parecem curar a enfermidade da vida, mas que incitam a doença da alma, cujos sintomas indicam um sofrimento eterno. Por isso, avisa o narrador da Constante Florinda que o amor humano é, enfim, sempre paixão que, perturbando o corpo, condena a alma. A absolvição ou a condenação final, porém, Deus é quem proferirá.

\footnotetext{
${ }^{563}$ De la sainte philosophie. Édition annotée par G. Michaut. Paris: J. Vrin, 1945, p.57.

${ }^{564}$ Não nos esqueçamos, a propósito, dos Sueños de Quevedo ou de La vida es sueño de Calderón de la Barca.
} 


\section{Considerações finais: \\ Palavras e coisas ou narração e doutrina}

Se ao longo do nosso estudo separamos, artificialmente, narração e doutrina, é preciso, por fim, mostrar que elas estão unidas, naturalmente, no texto da Constante Florinda. E para pensarmos nessa união, podemos recorrer àquela que se dá entre as palavras e as coisas, não nos esquecendo, porém, que na Constante Florinda todas as coisas são fictícias (res fictae), embora narradas como se fossem res factae. Assim, estas considerações finais, identificando palavras e coisas, tentam reunir narração e doutrina: síntese pressuposta desde o começo, mas que se impõe apenas no fim.

E para dar início ao fim, devemos lembrar que a metáfora, segundo Aristóteles, "consiste no transportar para uma coisa o nome de outra, ou do gênero para a espécie, ou da espécie para o gênero, ou da espécie de uma para a espécie de outra, ou por analogia" (Poética, XXI, 1457b, 6-7). Portanto, a metáfora, fonte por excelência de ensinamento e deleite, evidencia a semelhança entre as coisas. $\mathrm{O}$ poeta é aquele que descobre tal semelhança e que a exprime com palavras adequadas:

Grande importância tem, pois, o uso discreto de cada uma das mencionadas espécies de nomes, de nomes duplos e de palavras estrangeiras; maior, todavia, é a do emprego das metáforas, porque tal se não aprende nos demais, e revela portanto o engenho natural do poeta; com efeito, bem saber descobrir as metáforas, significa bem se aperceber das semelhanças (Poética, XXII, 1459a, 4-8).

No século XVII, com base nos preceitos aristotélicos, acentua-se a superioridade da metáfora como o meio mais eficaz de deleitar e instruir, e ela passa a ser considerada, então, "fundamento da agudeza e, de modo geral, de toda representação". ${ }^{565}$ Assim, aquelas semelhanças não se restringem mais às coisas ou às palavras que as nomeiam, mas são de tal forma exploradas que as palavras e as coisas se confundem, como explica António José Saraiva sobre o “discurso engenhoso":

${ }^{565}$ Hansen, João Adolfo. "Retórica da agudeza", op.cit., p.321. 
o texto e a coisa estão no mesmo plano. Passa-se de um a outro como se as aspas não exercessem função. Ora um texto é interpretado como coisa, ora a coisa como texto, ora um é o prolongamento do outro, ora eles se emaranham. De um texto extrai-se uma coisa; de uma coisa, uma palavra. As mesmas técnicas de análise verbal são válidas tanto para um como para outro. ${ }^{566}$

Isso porque, nos séculos XVI e XVII, a linguagem, dom dado por Deus, não é um conjunto de signos independentes, mas uma coisa da natureza. Tudo teve origem divina, coisas e signos. Quando a linguagem foi dada aos homens por Deus, ela era signo certo e transparente das coisas; porém, essa transparência foi destruída em Babel para punir os homens. "Mais si le langage ne ressemble plus immédiatement aux choses qu'il nomme, il n'est pas pour autant séparé du monde; il continue, sous une autre forme, à être lieu des révélations et à faire partie de l'espace où la vérité, à la fois, se manifeste et s'énonce". 567 O sábio, então, deve interpretar a "natureza escrita" através dos "comentários". Estes buscam restituir o plano uniforme das palavras e das coisas e revelar o Texto primitivo ou primeiro que há sob a linguagem. Enfim,

Le commentaire ressemble indéfiniment à ce qu'il commente et qu'il ne peut jamais énoncer; tout comme le savoir de la nature trouve toujours de nouveaux signes à la ressemblance parce que la ressamblance ne peut être connue par elle-même, mais que les signes ne peuvent être autre chose que des similitudes. Et de même que ce jeu infini de la nature trouve son lien, sa forme et sa limitation dans le rapport du microcosme au macrocosme, de la même façon la tâche infinie du commentaire se rassure par la promesse d'un texte effectivement écrit que l'interprétation un jour révélera en son entier. ${ }^{568}$

No entanto, a linguagem, como coisa humana, é imperfeita e a interpretação, que depende dos signos (humanos), jamais revelará o Texto primitivo. As formas perfeitas e imateriais da linguagem somente as possuem os seres mais elevados, como os anjos. Quanto aos homens, eles não podem ver face a face o Original dos conceitos,

\footnotetext{
${ }^{566}$ O discurso engenhoso: Estudos sobre Vieira e outros autores barrocos. São Paulo: Perspectiva, 1980, p.88.

${ }^{567}$ Foucault, Michel. Les mots et les choses: Une archéologie des sciences humaines. Paris: Gallimard, 2007, p.51.

${ }^{568}$ Idem, pp.56-57.
} 
sem a interpretação da "lingua mentitrice", como afirma Tesauro em seu Cannocchiale Aristotelico ao descrever "a comunicação angelical de conceitos":.569

Et questa Argutia Archetipa è quella, il cui protratto intendiamo di colorir nell'animo altrui per via de'simboli esteriori: non essendoci permesso de tramandarlo da spirito à spirito, senza il ministerio de'sensi. Et questa fù la sciocca rabbia di Socrate, incolpante la Natura del non havere aperto una finestretta in petto agli huomini, per veder faccia à faccia l'Originale de'lor concetti, senza interpretamento di lingua mentitrice; le cui traditioni souente son tradimenti. Contro alla qual querela potea compor la Natura il suo apologetico; rispondendo, ch'ella harebbe ad un tempo defraudato gli'nggnosi del diletto di tante belle Arti sermonali. L'Angelo adunque, \& l'Anima sgombra d'ogni corporeo impaccio; può senza mezzo effigiar nell'altro Spirito le spiritali imagini de'suoi pensieri; facendosi l'uno all'altro hor pittore, \& hor pittura; che è il corto, \& natural linguaggio degli Angeli. ${ }^{570}$

Essas concepções cristãs da linguagem têm como uma de suas principais fontes o De Doctrina Christiana de Santo Agostinho, ${ }^{571}$ sabendo-se que essa obra teve grande repercussão entre os tratadistas cristãos dos séculos XVI e XVII, como apontam Aníbal Pinto de Castro ${ }^{572}$ e Marc Fumaroli. ${ }^{573}$ Nos livros I e II do tratado de Agostinho são estudados, respectivamente, as coisas (res) e os signos (signa). Porém, destacaremos apenas um trecho do início do texto, no qual há importantes considerações sobre as res e os signa, assim como acerca de suas relações:

\footnotetext{
${ }^{569}$ Cf. Carvalho, Maria do Socorro Fernandes de. Poesia de agudeza em Portugal. São Paulo: Humanitas; Edusp; Fapesp, 2007, pp.106-107.

${ }^{570}$ Tesauro, Emanuele. Il Cannocchiale Aristotelico. Torino: Per Battolomeo Zauatta, 1670, cap. II, p.16.

${ }^{571}$ Para o texto latino, consultamos a seguinte edição: L'istruzione cristiana. A cura di Manlio Simonetti. Verona : Arnoldo Mondadori, 1994. E também consultamos a tradução para o português: A doutrina cristã: manual de exegese e formação cristã. Trad. Nair de Assis Oliveira. São Paulo: Paulus, 2002.

${ }^{572}$ Aníbal Pinto de Castro mostra, por exemplo, como um dos tratados que mais determinou a eloquiência cristã em fins do século XVI e no século XVII, a Rhetorica ecclesiastica de Luís de Granada, dependia, diretamente, das idéias do De Doctrina Christiana agostiniano, em particular, do livro IV. Eis uma das afirmações de Castro sobre as "dívidas" do tratado de Granada: "De entre todas estas dívidas são significamente vultuosas as que contraiu para com as obras de Quintiliano e Santo Agostinho" (Retórica e teorização literária em Portugal, op.cit., p.53).

${ }^{573}$ Fumaroli considera o De Doctrina Christiana (na verdade, seu livro IV) como a última retórica antiga e a primeira retórica eclesiástica (L'âge de l'éloquence, op.cit., pp.70-76).
} 
Omnis doctrina vel rerum est vel signorum, sed res per signa discuntur. Proprie autem nunca res appelavi quae non ad significandum aliquid adhibentur, sicuti est lignum lapis pecus atque huiusmodi cetera, sed non illud lignum quod in aquas amaras Moysen misisse legimus ut amaritudine carent, neque ille lapis quem Iacob sibi ad caput posuerat, neque illud pecus quod pro filio immolavit Abraham. Hae namque ita res sunt, ut aliarum etiam signa sint rerum. Sunt autem alia signa quorum omnis usus in significando est, sicuti sunt verba. Nemo enim utitur verbis, nisi aliquid significandi fratia. Ex quo intellegitr quid appellem signa, res eas videlicet quae ad significandum aliquid adhibentur. Quam ob rem omne signum etiam res aliqua est: quod enim nulla res est, omnino nihil est; non autem omnis res etiam signum est (De Doctrina Christiana, I, 2). ${ }^{574}$

Para Agostinho, toda doutrina são coisas e signos. Porém, as res só são "ditas" e, conseqüentemente, conhecidas através dos signa. A coisa não significa nada além de si mesma, a não ser em alguns casos excepcionais, como a "vara" de Moisés, a "pedra" de Jacó ou o "cordeiro" que Abraão imolou, que, apesar de serem res, tornaram-se também signa de outras coisas. Alguns signos, como as palavras (uerba), são empregados apenas para significarem algo. O signum é então definido como res usada para significar algo além de si. Portanto, todo signo é também uma coisa, pois se não fosse res, nada seria. Por outro lado, nem toda coisa é signum. Assim, nota-se que desde Santo Agostinho as coisas e os signos se confundem: embora diferentes, parecem inseparáveis, às vezes indistiguíveis, pois, como vimos, a res é por vezes signum e todo

\footnotetext{
${ }^{574} \mathrm{O}$ mesmo trecho é traduzido por Nair de Assis Oliveira da seguinte maneira: "Toda doutrina reduz-se ao ensino das coisas e ao dos sinais. Mas as coisas são conhecidas por meio dos sinais. Portanto, acabo de denominar coisas a tudo o que não está empregado para significar algum outro objeto como, por exemplo, uma vara, uma pedra, um animal ou outro objeto análogo. Não me refiro, contudo, àquela vara da qual lemos que Moisés atirou às águas amargas para diluir sua amargura (Ex15,25). Nem à pedra que Jacó pôs debaixo da cabeça, como almofada (Gn 28,11). Nem àquele cordeiro que Abraão imolou no lugar de seu filho (Gn 22, 13). Esses objetos, de fato, são coisas, masnas circunstâncias mencionadas tornaram-se ao mesmo tempo sinais de outras coisas. Existem sinais, mas de outro gênero, cujo emprego selimita unicamente a significar algo, como é o caso das palavras (verba). Ninguém emprega as palavras a não ser para significar alguma coisa com elas. Daí se deduz que denomino sinais a tudo o que se emprega para significar alguma coisa além de si mesmo. É porque todo sinal é ao mesmo tempo alguma coisa, visto que, se não fosse alguma coisa, não existiria. Mas, por outro lado, nem toda coisa é ao mesmo tempo sinal" (A doutrina cristã, op.cit., pp.42-43).
} 
signum é também res. Mas Agostinho os separa, estudando primeiro as coisas, no livro I, e depois os signos, no livro II. ${ }^{575}$

$\mathrm{Na}$ narração da Constante Florinda, coisas (res fictae) e palavras se identificam: ambas significam algo além de si mesmas e legam ao leitor ensinamentos. Em suas andanças pelo mundo, Florinda, ou melhor, Leandro se deparou com um grupo de pastores e, encantado por essa companhia tão aprazível e pelo locus amoenus em que se encontrava, decide ali ficar, "parecendo-lhe que entre gente tão solitária passaria sua vida mais encoberta". Mas a fortuna continua a persegui-lo. As novas sobre a beleza, graça e discrição do suposto rapaz espalharam-se logo e, entre as pastoras da aldeia onde ele morava e também entre aquelas das aldeias circunviznhas, "não havia nenhuma que não andasse rendida a seu amor". Assim, organizou-se uma festa para que todas essas pretendentes pudessem disputar o amor de Leandro. Essa disputa se deu da seguinte maneira: num belo vale, com uma variedade de flores e árvores, cada pastora deveria colher uma planta ou bonina e oferecê-la a Leandro para que, "dando-lhe ele a significação dela, diga a propósito alguma cousa tocante e dirigida ao amor que cada uma lhe tem; e aquela que melhor e mais apropositado dito disser, essa seja a que Leandro há de ter por senhor e a quem há de ser ele amante". ${ }^{576}$

Nessa competição entre as pastoras, as coisas, como signa, significam algo além do que são, e as palavras, como res, constituem a "natureza escrita". E quem conseguir ler e interpretar melhor essa natureza constituída por palavras é que merecerá o prêmio: ser amante de Leandro. A vencedora foi uma pastora misteriosa que surgiu no fim da disputa; na verdade, tratava-se de Artêmia, uma personagem cuja história fora contada nos capítulos VI e VII da obra. Artêmia, por desprezar os amores de Felício, foi difamada pelo rapaz, que dizia tê-la desonrado. O pai da donzela, acreditando na suposta desonra da filha, mandou um empregado tirar a vida da moça: ela foi, então, jogada no rio para morrer, mas acabou sobrevivendo. Desse modo, Artêmia, assim como Florinda (ou Leandro), passou a peregrinar pelo mundo suportando os infortúnios

\footnotetext{
575 O próprio autor explica por que fez tal divisão: "Quoniam de rebus cum scriberem, praemisi commonens ne quis in eis attenderet nisi quod sunt, non etiam si quid aliud praeter se significant; vicissim de signis disserens hoc dico, ne quis in eis attendat quod sunt, sed potius quod signa sunt, id est, quod significant" (De Doctrina Cristiana, II, 1). Na tradução de Nair de Assis Oliveira, o mesmo trecho aparece da seguinte forma: "Ao escrever o livro anterior sobre as coisas (De rebus), procurei previnir que se fizesse atenção, aí, apenas ao que as coisas são em si próprias, prescindindo do que possam significar além de seu sentido próprio (I, 2, 2). Agora, ao tratar sobre os sinais (de signis), advirto que não se dê atenção ao que as coisas são em si, mas unicamente ao que significam, isto é, que elas se manifestam sinais de algo diferente" (A doutrina cristã, op.cit., p.85).

${ }^{576}$ Infortúnios trágicos da constante Florinda, cap. XXI, p.178.
} 
que a vida lhe impôs. Enfim, vejamos como essa "pastora misteriosa" venceu a disputa pelos amores de Leandro:

...viram vir a pastora com quatro pastores velhos da aldeia, que por cortesia a vinham acompanhando; e chegando mais perto se ergueram as outras e a foram receber ao caminho com muita cortesia, porém ainda que trabalhavam pela conhecer não puderam, porque além de ser estrangeira vinha com o rosto coberto com uns antolhos de cristal mui claros; porém bem julgaram que devia de ser pastora de muito ser, conforme a gravidade de sua pessoa mostrava e a riqueza de seus vestidos pedia, os quais eram de brocado azul e verde, forrados de cetim amarelo, sameado todo de alcachofras de ouro e prata, assentado sobre seda vermelha, tão novo como que àquela hora se acabara de fazer, e com os raios do Sol deitava de si tanta claridade que não havia quem livremente segurasse a vista neles; em os pés trazia umas alpargates de âmbar com miúdas pérolas e grãos de aljôfar, em o pescoço uma grossa gargantilha de várias pedras, que sobre tudo the dava mais graça; seus cabelos levava soltos e enastrados a poucos, de maneira que a uns poucos espargidos se seguiam outros tanos feitos em trança com uma de ouro mui fina. Em a cabeça levava uma capela de cheirosas violetas e flores narcisas e miúdos ramos de verde salsa, entressachados doutros de cheirosa manjerona. Despois que as pastoras viram a gravidade desta e a variedade de boninas de que trazia composta sua capela, começaram entre si maravilhando-se dar cada uma o parecer que julgavam; uma dizia que tal pastora como aquela não era natural de aquelas partes, que se o fora não havia de vir disfarçada como ela vinha; outras diziam que devia de conhecer a Leandro, pela confiança que mostrava em sua pessoa e a significação das flores pedia; porque violas que significavam conhecimento, que devia de ser de o ter dele; e pelas flores narcisas, que significavam gentileza, que ou era pela que conhecia já de Leandro, ou confiada em sua fermosura; pela salsa que significava gosto, que não devia de ser senão pelo que tinha de o ver, e o mesmo mostrava a manjerona, pois significava prazer. Finalmente elas estavam mui espantadas de tal novidade e desejosas de saberem já o secreto dela; e quanto mais se detinha em descobri-lo, tanto mais elas desejavam de sabê-lo; porque a 
tardança que sepõe em descobrir algum segredo, serve de esporas que avivam o desejo de quem quer ouvi-lo. O que ela como avisada conhecendo, tomou um ramo de cerejeira que em a mão levava e chegando-se a Leandro lho ofereceu em a sua, fazendo-lhe uma grande cortesia; e vendo ele a notável graça de sua pessoa e boa postura de corpo, efeitos de que se esperava nobre causa, pagando-lhe com outra igual the falou desta maneira:

- Grave pastora, em verdade que me tem tão admirado, assi a novidade de vossa vinda, como a gravidade e bom talhe de vosso corpo, juntamente com a riqueza dos vestidos com que o trazeis ornado, que não posso negar a esperança que tenho de vossa fermosura e nobreza ser a que tais efeitos prometem: porém se sois servida de nos dizerdes quem sois, descobrindo vosso rostro antes que vos declare a significação de vossa frol, a mi me obrigareis a servir-vos, e a todas estas pastoras satisfareis o grande desejo que têm de vos conhecer, e quando não, determinai tudo à medida de vosso gosto, que em tudo trabalharei por vo-lo causar.

- Rezão era, nobre Leandro (respondeu ela), que não repugnará a vossa vontade quem não tem outra mais que de ser sujeita a ela; porém por agora me perdoai que até se não dar sentença, nem meu rostro será visto, nem minha pessoa conhecida.

- Pois como assim é (respondeu ele), quero-vos satisfazer com brevidade para que a ponhamos no fim de nossos desejos. Pelo que haveis de entender que a verdadeira e própria significação da cerejeira é apetite.

Ao que ela respondeu: - Este não no hei mister, porque tenho tanto para vos querer, quanto de amor para em tudo vos merecer. ${ }^{577}$

Nesse longo trecho, as flores, os ramos, os corpos, as roupas não significam apenas "coisas". Cada espécie de flor, por exemplo, tem diferente "significação": a viola mostra conhecimento, a narcisa, gentileza, a salsa, gosto, e a manjerona, prazer. Além disso, a gravidade e o bom talhe do corpo e a riqueza dos vestidos que o ornam indicam formosura e nobreza. Essas coisas são signos, cuja significação é revelada pelos comentários do narrador e dos personagens, ou seja, as palavras é que escrevem a natureza, que é lida e interpretada, também com palavras, para deleite e instrução dos

${ }^{577}$ Idem, capítulo XXII, pp.186-188. 
leitores. Não é mostrar o ramo de cerejeira como "coisa" o que dá a vitória à pastora desconhecida (que, como dissemos, é Artêmia); o ramo de cerejeira significa apetite, afirma Leandro, e comentando essa significação, com uma sentença aguda, é que a suposta pastora vence a disputa.

Assim, as palavras e as coisas se confundem, deleitando e ensinando. O quadro narrado no excerto citado, que está inserido no episódio da estada de Leandro entre os pastores, compõe-se, fundamentalmente, de descrições, e as coisas descritas, como os trajes da pastora misteriosa, adquirem "significações", como se fossem palavras. Estas, por outro lado, substituem, às vezes, as próprias coisas: a sentença final da personagem ("Este não no hei mister, porque tenho tanto para vos querer, quanto de amor para em tudo vos merecer") refere-se à palavra "apetite", que, no caso, não significa apenas um afeto, mas é também a própria coisa que está nas mãos de Leandro - o ramo de cerejeira. Portanto, os limites entre coisas e palavras não ficam evidentes: ao contrário, o que se ressaltam são suas semelhanças, que, por vezes, se tornam identidades.

Essas "coisas" (flores, ramos, trajes etc.) são aquilo que o texto apresenta elocutivamente, ou seja, o que ele mostra ao leitor por meio de palavras, fazendo uso, por exemplo, de metáforas. ${ }^{578}$ Entretanto, mesmo sendo esse texto ficção, não podemos nos esquecer que nas retóricas antigas as res são entendidas, às vezes, também como os "pensamentos" adequados à matéria do discurso e buscados na inuentio $;{ }^{579}$ ao passo que os uerba revestem e exprimem essas res da invenção na elocutio. ${ }^{580}$ Além disso, outras vezes, a res (no singular) refere-se à própria matéria (ou assunto) sobre a qual se discorre. ${ }^{581}$ Ao mencionar essas noções de res e uerba dos tratados retóricos, não

\footnotetext{
${ }^{578}$ Nesse sentido, vale a pena recordar o que afirma Aristóteles sobre as metáforas: "É ainda necessário usar metáforas provindas não de coisas muito afastadas, mas de coisas semelhantes e da mesma espécie da do termo usado, designando assim algo que não tem designação, de forma a que seja evidente que estão relacionadas" (Retórica, III, 2, 1405a). Porém, a metáfora não deve provir de coisas que apresentem semelhanças muito óbvias: "é forçoso que as metáforas provenham de coisas apropriadas, mas não óbvias, tal como na filosofia é próprio do espírito sagaz estabelecer a semelhança mesmo com entidades muito diferentes" (Idem, III, 11, 1412a). Portanto, o filósofo (assim como o poeta) é capaz de perceber a semelhança entre as coisas, ainda que elas sejam muito distintas.

579 Conforme a explicação de Henrich Lausberg: "A primeira fase da elaboração é a inventio, i.é, o acto de encontrar pensamentos (res) adequados (aptum) à matéria, conforme o interesse do partido representado (utilitas causae), pensamentos que servem como instrumentos intelectuais e afectivos para obter, pela persuasão do juiz, a vitória do partido representado. Esta persuasão, em si mesma, consegue-se pela criação de um grau de credibilidade elevado, mesmo quando a materia em si desfrutava, de antemão, apenas de um grau muito baixo de credibilidade" (Elementos de retórica literária. Tradução, prefácio e aditamentos de R. M. Rosado Fernandes. $5^{\text {a }}$ ed. Lisboa: Fundação Calouste Gulbenkian, 2004, p.91).

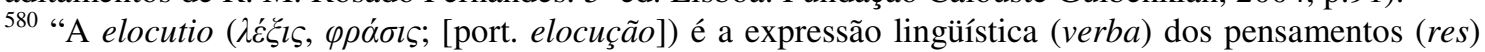
encontrados pela inventio" (Idem, p.115).

${ }^{581}$ Um bom exemplo desse uso de res é o seguinte trecho da Rhetorica ad Herennium: "Quoniam in hoc libro, Herenni, de elocutione conscripsimus et, quibus in rebus opus fuit exemplis uti, nostris exemplis usi sumus et id fecimus praeter consuetudinem Graecorum, qui de hac re scripserunt, necessario faciendum
} 
queremos dizer que são as mesmas que encontramos numa obra fictícia, mas elas podem nos ajudar a pensar, por analogia, nas relações entre narração e doutrina.

No "prólogo ao leitor" da segunda parte da Constante Florinda, o autor explica qual é o intento da obra:

Muitos cervos há no mundo que são servos do mundo, os quais só com eles tratam seus negócios, metidos em os bosques de cuidados mundanos, sustentando-se em os montes de pensamentos altivos, sem quererem tomar conselho com um livro espiritual que lhes ensine o que devem fazer. Compadecido destes, quis disfarçar exemplos e moralidades com as roupas de histórias humanas, para que vindo buscar recreação para o entendimento em a elegância das palavras, em o enredo das histórias, em a curiosidade das sentenças e em a lição das fábulas, achem também o proveito que estão oferecendo, que é um claro desengano das cousas do mundo, e fiquem livres dos perigos, a que estão mui arriscados, com seus ruins conselhos. ${ }^{582}$

Portanto, segundo esse trecho do prólogo, o propósito do texto é mover os leitores pela recreação e pelo proveito, disfarçando exemplos e moralidades com as roupas de histórias humanas. E o proveito que o texto oferece é "um claro desengano das cousas do mundo". Conseqüentemente, para esse intento está voltada a matéria (res) principal da obra (os infortúnios trágicos de Florinda e Arnaldo), assim como sua narração e sua doutrina. Se, como afirmou Santo Agostinho, toda doutrina são coisas e signos, podemos dizer que toda narração são palavras e coisas. E a narração da Constante

est, ut paucis rationem nostri consilii demus. Atque hoc necessitudine nos facere, non studio, satis erit signi, quod in superioribus libris nihil neque ante rem neque praeter rem locuti sumus. Nunc, si pauca, quae res postulat, dixerimus, tibi id, quod reliquum est artis, ita uti instituimus, persoluemus. Sed facilius nostram rationem intelleges, si prius, quid illi dicant, cognoueris (IV, 1)". Na tradução de Ana Paula Celestino Faria e Adriana Seabra, eis como aparece o mesmo trecho: "Já que neste livro, Herênio, escrevemos sobre a elocução e, quando foi preciso usar exemplos, usamos nossos próprios - contra o hábito dos gregos que escreveram sobre o mesmo assunto -, faz-se necessário que apresentemos, em poucas palavras, as razões dessa nossa decisão. Sinal suficiente de que o fizemos por necessidade, não por capricho, é o fato de nada termos dito nos livros anteriores, nem antes, nem depois de tratar a matéria. Agora, assim que dissermos resumidamente o que demanda o assunto, continuaremos o que iniciamos, explicando para ti o restante da arte. Entenderás, contudo, mais facilmente a nossa razão se antes souberes o que dizem os gregos" (Retórica a Herênio, op.cit., p.199). Fica evidente que a res de que se fala é a matéria ou assunto do livro IV da Rhetorica ad Herennium: a lexis dos gregos ou a elocutio dos latinos. A dificuldade declarada pelo autor está em tratar de um assunto (res) que só tinha sido devidamente estudado pelos gregos.

${ }^{582}$ Segunda parte da Constante Florinda, "Prólogo ao leitor", p.130. 
Florinda, além de deleitar, é também doutrina que ensina, com exempla estóicos, como devem se "comportar"

Desse modo, as palavras narradas são as coisas ensinadas. Da narração, indicamos alguns procedimentos retóricos e poéticos (nos capítulos 1 e 2); da doutrina, ressaltamos as res estóicas (nos capítulos 3 e 4). A separação que fizemos é artifício, como aquela que fez Santo Agostinho no De Doctrina Christiana: no livro I expôs as coisas, no livro II, os signos. Numa ordem invertida, nossa exposição visou primeiro às palavras e depois às coisas. Mas vale repetir: nosso estudo é artifício, pois palavras são coisas e coisas são palavras; distingui-las, ainda mais se tratando de um texto do século XVII, é separar o que tem em Deus assegurada a sua identidade, porque se tudo se origina em Deus, tudo é semelhante e toda semelhança é divina.

O que demonstramos em nossas análises foi que a doutrina da Constante Florinda depende, em grande medida, dos ensinamentos estóico-cristãos que circularam em diversos textos dos séculos XVI e XVII. Porém, essa doutrina se constitui na narração, que ecoa, por sua vez, preceitos retórico-poéticos. Destacamos algumas técnicas retóricas e poéticas da persona que narra os infortúnios de Florinda e Arnaldo; narrador esse que põe diante dos olhos, através das palavras, exempla estóicos que movem os leitores à vida cristã. Como as palavras e as coisas, procedimentos retóricos e poéticos e conhecimentos filosóficos também se unem nessa narração que é deleite e doutrina.

Nas andanças de Arnaldo pelo mundo, sabemos que ele se tornou cativo do mouro Hamete. Nesse cativeiro, Arnaldo reencontra-se com o caçador (Flamiano), pois, como já dissemos, o caçador, que surgiu no começo da narração, entrou numa torre e conversou com um "mancebo"; esse rapaz, como se explica muitos capítulos depois, era Arnaldo, com quem Flamiano tem esse surpreendente reencontro em terras mouras. Mas o que queremos destacar, nesse episódio que se passa em território mouro, é uma história que Arnaldo relata a Flamiano. O amado de Florinda, na incansável busca por sua donzela, conheceu um letrado que vivia numa torre, localizada na cidade de Cardona, no reino de Catalunha. Esse letrado deu conta de sua vida a Arnaldo que, por sua vez, conta-a para Flamiano, sendo este último relato um bom exemplo da

\footnotetext{
${ }^{583}$ É importante destacar que o verbo "comportar" aparece, no Vocabulário Português e Latino, como sinônimo de "sofrer" e de "tolerar" (Bluteau, Raphael. Vocabulario Portuguez, e Latino, op.cit., verb. “comportar").
} 
complexidade da narração da Constante Florinda: são diversas histórias dentro de outras histórias, variando e ornando a história de Florinda e Arnaldo.

Pois bem. Arnaldo reproduz, então, para Flamiano o relato do letrado: este se chamava Ródio e era natural da cidade de Cardona. Quando era ainda de pouca idade, foi estudar em Barcelona e lá conheceu um outro estudante, Milício, que também nascera em Cardona, e com quem criou forte vínculo de amizade. No entanto, os dois se apaixonaram pela mesma donzela, "em cujo amor perseveraram por mais de um ano, sem saber um do outro". Um dia, a donzela, chamada Cardênia, confessou que amava somente Ródio e, portanto, Milício ficou muito sentido. "E porque um mal grande muitas vezes é causa de outros peores, daqui nasceu a Milício cobrar a Ródio uma enveja que o abrasava, porque o via mais amado e de novo favorecido de Cardénia". Assim, Milício tentou se vingar: mandou uma carta para sua cidade natal (Cardena), pedindo para que uns parentes seus tirassem a vida de Ródio. Mas essa primeira vingança não deu certo. Depois disso, esses dois rapazes acabaram compartilhando uma tristeza comum: surpreendentemente, Cardênia, sem lhes dar nenhuma explicação, casou-se com um outro rapaz; um sucesso repentino e pesaroso que reaproximou um pouco aqueles dois velhos amigos. Após alguns anos persistindo em seus estudos, Milício abandonou as letras e voltou para Cardona, pois com a morte de seu pai, herdou muitos bens na cidade. Milício, porém, não esqueceu do agravo daquela mulher que tanto amara e, para se vingar, mandou "furtar" a filha de Cardênia, "deixando a mãe trespassada com a seta de tão grande crueldade e envolta em os braços do sentimento". E por mais que Cardênia tenha tentado encontrar a filha (que tinha, na época de seu desaparecimento, apenas quatro anos), nunca mais teve notícias dela. Depois desses acontecimentos, Ródio, que concluíra seus estudos na Universidade de Alcalá, também retornou para sua cidade natal que, como sabemos, era a mesma de Milício: Cardona. Lá, Ródio conheceu Ledea, a filha de Cardênia que já estava com dez anos de idade e que Milício criava para ser sua esposa, renovando nela o antigo amor que tivera à sua mãe. Com o passar dos anos, Ledea se tornou uma donzela tão formosa quanto sua mãe e, também como Cardênia, interessou-se por Ródio e prometeu casar-se com ele. Desse modo, quando Ledea tinha quinze anos de idade e estando ausente Milício da cidade, Ródio aproveitou a oportunidade para se casar com a donzela. Assim que Milício voltou a Cardona e soube desse casamento, sentiu-se desonrado e tratou, mais uma vez, de vingar-se de Ródio. E vingou-se com uma dura traição: Milício seduziu Ledea que, "como era moça pouco considerada", acabou se rendendo a esse amor adúltero, e logo 
se espalhou por toda a cidade a notícia do adultério. Agora, então, era a vez de Ródio punir esses traidores. Surpreendendo os adúlteros num aposento de sua própria casa, Ródio matou Milício com duas punhaladas e, em seguida, foi tirar a vida de Ledea com o mesmo instrumento. Porém, antes de as punhaladas materam-na, ela abriu a janela do aposento e pulou, já bastante ferida, no rio, tingindo com seu sangue as claras águas, às quais Ródio também lançou o corpo de Milício, "para que o vizinho rio fosse testemunha de sua causa e suas águas levassem novas até o Mar Oceano, para que todos soubessem que estava já satisfeito de seu agravo". Após se livrar com facilidade da justiça, já que tinha matado para vingar a desonra sofrida, Ródio continou a viver em sua casa que, na verdade, era a "torre" na qual, anos depois de todos esses sucessos trágicos, Arnaldo encontrou-o, ou melhor, conheceu o "Letrado".

Terminado o relato de Arnaldo, que reproduziu aquele de Ródio, Flamiano, que ouvia a história com atenção, fez o seguinte comentário:

- Em verdade, que assim como esses sucessos, e outros semelhantes causam admiração ao entendimento, que também são para a alma de muito proveito, porque obrigam aos homens a fugir dos vícios, pois tem o castigo tão certo, e seguir as virtudes, que nunca tiveram o prémio duvidoso. ${ }^{584}$

E respondeu Arnaldo: “Assim é, porque não há vício sem castigo, nem virtude sem prémio".

Portanto, reafirma-se o proveito das histórias narradas: elas querem ensinar os homens (cristãos) a fugirem dos vícios e seguirem as virtudes. Para tanto, os personagens e o narrador não cansam de lembrar que todo vício será sempre castigado e toda virtude será sempre premiada. E a narração dos infortúnios trágicos de Florinda e Arnaldo, como mostramos em nosso trabalho, traz um proveito que ecoa a doutrina estóico-cristã:

Nunca as cousas da ventura estão menos seguras que quando estão mais prósperas. Esta verdade experimentaram Arnaldo e sua esposa Florinda,

${ }^{584}$ Segunda parte da Constante Florinda, capítulo XVI, p.179. 
porque quando os tinha posto na altura da maior prosperidade, então caíram em o baixo da morte. ${ }^{585}$

A narração da Constante Florinda são palavras narradas, que, por sua vez, são coisas ensinadas, que, enfim, constituem a doutrina; e tudo se dá simultaneamente no texto. No nosso estudo separamos, artificialmente, narração e doutrina, como também se separam artificialmente, nos tratados retóricos, invenção, disposição e elocução. O texto da Constante Florinda não é um discurso oratório e o nosso estudo não é um tratado retórico, mas num discurso é possível distinguir procedimentos inventivos, dispositivos e elocutivos, assim como na obra que estudamos distinguimos a narração (ou seus procedimentos) e a doutrina (ou seus ensinamentos). E assim fizemos visando à clareza da nossa exposição.

Naquele texto, no entanto, as palavras que narram são as mesmas que doutrinam. Palavras estóicas e coisas cristãs ou coisas estóicas e palavras cristãs, tudo indica que o uerbum humano não é res divina, e o abismo que os separa é a própria linguagem ou, como diria Tesauro, nossa "lingua mentitrice”. Distantes ou coincidentes, as palavras e as coisas confluem na narração da Constante Florinda, confluem para desaguar no Verbum divino, palavra que é signo e significação, origem e fim de todas as coisas.

${ }^{585}$ Idem, capítulo último, p.266. 


\section{Referências bibliográficas}

\section{Edições consultadas das obras de Gaspar Pires de Rebelo}

REBELO, Gaspar Pires de. Infortunios Tragicos da Constante Florinda. Nesta segunda impressão, acrescentados pelo mesmo Autor. Lisboa: Antonio Alvarez, 1633.

- Infortunios Tragicos, da Constante Florinda. E agora nesta impressão correctos, e emendados. Lisboa: Na Officina de Francisco Borges de Sousa, 1761. - Infortúnios Trágicos da Constante Florinda. Edição de Artur Henrique Ribeiro Gonçalves. Lisboa: Universidade Nova de Lisboa, 2000.

. Infortúnios trágicos da Constante Florinda. Edição de Nuno Júdice. Lisboa: Teorema, 2005.

Infortúnios trágicos da constante Florinda. Organização, notas e posfácio de Adma Muhana. São Paulo: Globo, 2006.

Novelas Exemplares, compostas pelo Autor das duas partes da Constante Florinda. Lisboa: Na Officina de Miguel Deslandes, 1701.

\section{Retórica, poética e ficção}

1. Fontes

ALCIATI, Andrea. Emblemas. Edición y comentario de Santiago Sebastián; prólogo de Aurora Egido; traducción actualizada de los Emblemas de Pilar Pedraza. $2^{\mathrm{a}}$ ed. Madrid: Akal, 1993.

ALMEIDA, Manuel Pires de. Discurso sobre o Poema Heróico. Edição e comentário de Adma Muhana. REEL - Revista Eletrônica de Estudos Literários, Vitória, a.2, n.2, 2006, pp.1-22. Disponível em: http://www.ufes.br/ mlb/reel2/AdmaMuhana.pdf . Poesia e pintura, ou, Pintura e poesia: tratado seiscentista de Manuel Pires de Almeida. Adma Muhana; tradução do latim de João Ângelo Oliva Neto. São Paulo: Fapesp; Edusp, 2002. 
ARISTÓTELES. Ética a Nicômacos. Trad. Mário da Gama Kury. 4ª ed. Brasília: UnB, 2001.

Poética. Trad. Eudoro de Sousa. Porto Alegre: Globo, 1966.

Retórica. Trad. Manuel Alexandre Júnior, Paulo Farmhouse Alberto e Abel do Nascimento Pena. Lisboa: Imprensa Nacional - Casa da Moeda, 1998.

BLUTEAU, Raphael. Vocabulario Portuguez, e Latino (1712-1728). 10v. Facsimile reprint. Hildesheim; Zürich; New York: Georg Olms Verlag, 2002.

CALDERÓN DE LA BARCA, Pedro. La vida es sueño. Edición de Ciriaco Morón. Madrid: Cátedra, 1990.

CAMÕES, Luís de. Obra Completa. Rio de Janeiro: Nova Aguilar, 2005.

CASTIGLIONE, Baldassare. Il libro del cortegiano. A cura di Giulio Preti. Torino: G. Einaudi, 1960.

O cortesão. Trad. Carlos Nilson Moulin Louzada. São Paulo: Martins Fontes, 1997.

CERVANTES, Miguel de. El ingenioso hidalgo Don Quixote de la Mancha. Madrid: Juan de la Cuesta, 1605.

. Segunda parte del ingenioso cavallero Don Quixote de la Mancha. Madrid: Juan de la Cuesta, 1615.

. Los trabajos de Persiles y Sigismunda. Edición de Carlos Romero Muñoz.

Madrid: Cátedra, 2004.

Novelas Ejemplares. Edición de Harry Sieber. Madrid : Cátedra, 2004. 2v.

CÍCERO. De l'orateur. Texte établi et traduit par Edmond Courbaud. Paris: Les Belles Lettres, 1950.

. L'orateur: du meilleur genre d'orateurs. Texte établit et traduit par Albert

Yon. Paris: Belles Letres, 1964.

El Orador. Texto revisado y traducido por Antonio Tovar y Aurelio R.

Bujaldón. 2a ed. Madrid: Consejo Superior de Investigaciones Científicas

(C.S.I.C), 1992.

DELLA CASA, Giovanni. Galateo. Introduzione e note di Saverio Orlando. Milano: Garzanti libri, 1995.

. Galateo, ou, Dos costumes. Prefácio e notas de Alcir Pécora; trad. de Edileine

Vieira Machado. São Paulo: Martins Fontes, 1999.

FERREIRA, Francisco Leitão. Nova Arte de Conceitos. Lisboa occidental: Antonio Pedrozo Galram, 1718 e 1721. 2v. 
GRACIÁN, Baltasar. Agudeza y Arte de Ingenio. Edición, introducción y notas de Evaristo Correa Calderón. Madrid: Castalia, 1987. 2t.

HALICARNASSO, Dionísio de. Tratado da Imitação. Introd. Raul Miguel Rosado Fernandes. Lisboa: Imprensa Nacional - Casa da Moeda, 1986.

HELIODORO. Les Éthiopiques. Trad. J. Maillor. Troisième tirage. Paris: Les Belles Lettres, 1994. 3t.

HESÍODO. Teogonia. Tradução de Jaa Torrano. São Paulo: Iluminuras, 2006.

HOMERO. Ilíada. Tradução de Carlos Alberto Nunes. Rio de Janeiro: Ediouro, 2001. Odisséia. Tradução de Carlos Alberto Nunes. Rio de Janeiro: Ediouro, 2001.

HORÁCIO. Arte Poética. Intr., trad. e comentário de R. M. Rosado Fernandes. Lisboa: LCE, s/d (colecção bilíngüe).

Lazarilho de Tormes. Edición de Francisco Rico; con un apéndice bibliográfico por Bienvenido C. Morros. 6ª ed. Madrid: Cátedra, 1990.

LOBO, Francisco Rodrigues. Corte na Aldeia e Noites de Inverno. Prefácio e notas

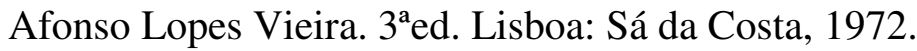

LONGUS. Daphnis et Chloé. Texte établi et traduit par Jean-René Vieillefond. Paris : Les Belles Lettres, 1987.

LOPE DE VEGA, Félix. El peregrino en su patria. Edición de Juan Bautista AvalleArce. Madrid: Castalia, 2006.

Novelas a Marcia Leonarda. Edición, prólogo y notas de Francisco Rico. Madrid: Alianza, 1968.

LÓPEZ PINCIANO, Alonso. Philosophía Antigua Poética. Obras completas, I. Edición de José Rico Verdú. Madrid: Biblioteca Castro, 1998.

MELO, Francisco Manuel de. Apólogos dialogais. Prefácio e notas do José Pereira Tavares. Lisboa: Sá da Costa, 1959. 2v.

A tuba de Caliope: quarta musa das Obras Métricas. Introdução, estabelecimento do texto, notas e glossário por Segismundo Spina. São Paulo: Brasiliense; EDUSP, 1988.

Carta de guia de casados. Ed. revista e prefaciada por Fernando de Castro Pires de Lima. Porto: Liv. Simões Lopes, 1949.

MONTEMAYOR, Jorge de. Los siete libros de la Diana. Edición de Asunción Rallo. Madrid: Cátedra, 1991.

PINTO, Fernão Mendes. Peregrinaçam. Ed. fac-similada. Transcrição de Adolfo Casais Monteiro. Lisboa: Imprensa Nacional-Casa da Moeda, 1984. 
PLATÃO. Górgias. Tradução, apresentação e notas Jaime Bruna. São Paulo: Difel, 1986.

Poesia seiscentista - Fênix renascida \& Postilhão de Apolo. Organização Alcir Pécora; Introdução João Adolfo Hansen. São Paulo: Hedra, 2002.

QUEVEDO, Francisco de. Los sueños. Edición de Ignacio Arellano. Madrid: Cátedra, 2003.

QUINTILIANO. Institution Oratoire. Trad. Henri Bornecque. Paris: Garnier Frères, 1954.

Obra completa. Edición bilingüe. Traducción y comentarios de Alfonso Ortega Carmona. Salamanca: Universidad Pontificia de Salamanca, 1999.

Retórica a Herênio. Tradução e introdução Ana Paula Celestino Faria e Adriana Seabra. São Paulo: Hedra, 2005.

RIBEIRO, Bernadim. Menina e moça ou saudades. Introdução e fixação do texto de Helder Macedo. Lisboa: D. Quixote, 1999.

RODRÍGUEZ DE MONTALVO, Garci. Amadís de Gaula. Edición de Juan Bautista Avalle-Arce. Madrid: Espasa Calpe, 1991. 2v.

SANTO AGOSTINHO. L'istruzione cristiana. A cura di Manlio Simonetti. Verona: Arnoldo Mondadori, 1994.

A doutrina cristã: manual de exegese e formação cristã. Trad. Nair de Assis Oliveira. São Paulo: Paulus, 2002.

TÁCIO, Aquiles. Le Roman de Leucippé et Clitophon. Trad. Jean-Philippe Garnaud. Deuxième tirage. Paris: Les Belles Lettres, 1995.

TASSO, Torquato. Discorsi dell'Arte Poetica e in particolare sopra il Poema Eroico.

In: Prose. A cura de Ettore Mazzali. Milano, Napoli: Riccardo Ricciardi, 1959., pp.349-410.

Discorsi del Poema Eroico. In: Prose. Milano: Rizzoli, 1935, pp.315-539.

TEOFRASTO. Os caracteres. Introdução, tradução e comentários de Daisi Malhadas e Haiganuch Sarian. São Paulo: E.P.U., 1978.

TESAURO, Emanuele. Il Cannocchiale Aristotelico. Torino: Per Battolomeo Zauatta, 1670.

Cannocchiale Aristotelico. Traducido al español por el R. P. M. Fr. Miguèl de Sequeyros. Madrid: Antonio Marin, 1741.

. L'idée de la parfaite devise. Traduction de Florence Vuilleumier; preface de Florence Vuilleumier et Pierre Laurens. Paris : Les Belles Lettres, 1992. 
VIRGÍLIO. Énéide. Texte établi par Henri Goelzer et traduit par André Bellessort. Paris : Les Belles Lettres, 1946. 2t.

2. Estudos

ARTAZA, Elena. El ars narrandi en el siglo XVI español. Teoría y práctica. Bilbao: Universidad de Deusto, 1989.

BALDWIN, Charles Sears. Ancient Rhetoric and Poetic. Westport, Connecticut: Greenwood, 1971.

BARTHES, Roland. "A retórica antiga". In: Pesquisas de Retórica. Trad. Leda Pinto Mafra Iruzum. Petrópolis: Vozes, 1975, pp. 147-221.

BRANDÃO, Jacyntho Lins. A invenção do romance: narrativa e mimese no romance grego. Brasília: UnB, 2005.

CARVAlHO, Maria do Socorro Fernandes de. Poesia de agudeza em Portugal. São Paulo: Humanitas; Edusp; Fapesp, 2007.

CASTRO, Aníbal Pinto de. Retórica e teorização literária em Portugal: do Humanismo ao Neoclassicismo. Coimbra : Atlântida, 1973.

CHASTEL, André. "Le Baroque et la mort". In: Retorica e Barocco. Atti del III Congresso Internazionale di Studi Umanistici. A cura di Enrico Castelli. Roma: Fratelli Bocca, 1955, pp.33-46.

CURTIUS, Ernst Robert. Literatura Européia e Idade Média Latina. Tradução Teodoro Cabral e Paulo Rónai. São Paulo: Hucitec; Edusp, 1996.

FERREIRA, João Palma. Novelistas e contistas portugueses dos séculos XVII e XVIII. Lisboa: Imprensa Nacional - Casa da Moeda, 1981.

FINAZZI-AGRÒ, Ettore. A novelística portuguesa do século XVI. Trad. Carlos Moura.

Lisboa: Instituto de Cultura Portuguesa, M.E.C., Secretaria de Estado da Cultura,1978.

FUMAROLI, Marc. L'âge de l'éloquence: rhétorique et "res literaria" de la Renaissance au seuil de l'époque classique. Paris: Albin Michel, 1996.

GARCÍA GUAL, Carlos. Los orígenes de la novela. Madrid: Istmo, 1972.

GONÇALVES, Artur Henrique Ribeiro. A retórica da citação pedagógica em Gaspar Pires de Rebelo (Frade seiscentista da ordem de Santiago). Faro: Universidade do Algarve, Escola Superior de Educação, 2002. 
Infortúnios Trágicos da Constante Florinda de Gaspar Pires de Rebelo: Uma novela de Amor e Aventuras Peregrinas. Tese para a obtenção do grau de doutor. Lisboa: Universidade Nova de Lisboa, 2000.

. Uma novela pícara portuguesa: O Desgraciado Amante. Dissertação para a obtenção do grau de mestre. Lisboa: Universidade Nova de Lisboa, 1994.

HÄGG, Tomas. The Novel in Antiquity. Oxford; New York: Basil Blackwell, 1983.

HANSEN, João Adolfo. Alegoria - construção e interpretação da metáfora. São Paulo: Hedra; Campinas: Editora da Unicamp, 2006.

A sátira e o engenho: Gregório de Matos e a Bahia do século XVII. $2^{\mathrm{a}}$ ed. rev.

São Paulo: Ateliê Editorial; Campinas: Editora da Unicamp, 2004.

. "Barroco, Neobarroco e Outras Ruínas". In: REEL - Revista Eletrônica de

Estudos Literários. Vitória, a.2, n.2, 2006, pp.1-60. Disponível em: http://www.ufes.br/ mlb/reel2/JoaoAdolfoHansen.pdf

. "Juízo e Engenho nas Preceptivas Poéticas do Século XVII". In: Evando Nascimento; Maria Clara Castellões de Oliveira. (Org.). Literatura e filosofia: diálogos. Juiz de Fora: Editora UFJF; São Paulo: Imprensa Oficial do Estado de São Paulo, 2004, pp.89-112.

. "Ut Pictura Poesis e Verossimilhança na Doutrina do Conceito no século XVII". In: Para Segismundo Spina: Língua, Filologia, Literatura. São Paulo: Edusp; Iluminuras, 1995, pp.201-214. "Retórica da Agudeza". In: Letras Clássicas, n. 4, 2000, pp.317-342.

KENNEDY, George A. A new history of classical rhetoric. Princeton, New Jersey: Princeton University Press, 1994.

KLEIN, Robert. "A teoria da expressão figurada nos tratados italianos sobre as imprese, 1555-1612”. In: A forma e o inteligível: escritos sobre o renascimento e arte moderna. Trad. Cely Arena. São Paulo: Edusp, 1998, pp.117-140.

LAUSBERG, Heinrich. Manual de Retórica Literaria. Versión española de José Pérez Riesco. Madrid: Gredos, 1975.

Elementos de Retórica Literária. Tradução, prefácio e aditamentos de R. M. Rosado Fernandes. $5^{\text {a }}$ ed. Lisboa: Fundação Calouste Gulbenkian, 2004.

LÓPEZ GRIGERA, Luisa. La Retórica en la España del Siglo de Oro. Salamanca: Universidad de Salamanca, 1994.

MARÍN, Francisco Marcos. Poesía narrativa árabe y épica hispánica: elementos árabes en los orígenes de la épica hispánica. Madrid: Gredos, 1971. 
MENÉNDEZ Y PELAYO, Marcelino. Orígenes de la novela. Madrid: Bailly, 1925. 4t.

MUHANA, Adma. A epopéia em prosa seiscentista: uma definição de gênero. São Paulo: Unesp; Fapesp, 1997. . "Causas da poesia na Poética". In: Phaos - Revista de Estudos Clássicos, Campinas,v. 4, 2004, pp. 97-109. . "O gênero epistolar: diálogo per absentiam". In: Discurso. São Paulo, USP, n.31, 2000, pp.329-45.

PÉCORA, Alcir. Máquina de Gêneros. São Paulo: Edusp, 2001.

Teatro do Sacramento. São Paulo: Edusp, 1994.

PERRY, Ben Edwin. The ancient romances: A literary-historical account of their origins. Berkeley; Los Angeles: University of California Press, 1967.

PINEDA, Victoria. La imitación como arte literario en el siglo XVI español. Sevilla: Diputación Provencial de Sevilla, 1994.

PLEBE, Armando. Breve história da retórica antiga. Tradução e notas Gilda Maciel de Barros. São Paulo: E.P.U, Edusp, 1978.

QUINT, Anne-Marie. "Gaspar Pires de Rebelo, explorateur de nouvelles voies romanesques au Portugal'.In: Mateo Alemán et les voies du roman au tournant des XVIe et XVIIe siècles, Les Cahiers FORELL, Université de Poitiers, 2001, p. 165-176.

. "Tragiques Infortunes: Violence et transgression dans les romans de Gaspar Pires de Rebelo".In: Hommage au Professeur Claude Maffre, Université de Montpellier III, ETILAL, 2003, p. 117-129.

SARAIVA, António José. O discurso engenhoso: Estudos sobre Vieira e outros autores barrocos. São Paulo: Perspectiva, 1980.

SHEPARD, Sanford. El Pinciano y las Teorías Literarias del Siglo de Oro. Segunda edición aumentada. Madrid: Gredos, 1970.

SPINA, Segismundo. Introdução à poética clássica. $2^{\mathrm{a} e d}$. rev. São Paulo: Martins Fontes, 1995.

TAGLIABUE, Guido Morpurgo. "Aristotelismo e Barocco". In: Retorica e Barocco. Atti del III Congresso Internazionale di Studi Umanistici. A cura di Enrico Castelli. Roma: Fratelli Bocca, 1955, pp.119-195.

\section{Filosofia estóica}


1. Fontes

CÍCERO. De natura deorum ; Academica. With an english translation by H. Rackham. Cambridge, Mass.; London : Harvard University Press: W. Heinemann, 1979. . Des termes extrêmes des biens et des maux. Texte établi et traduit par Jules Martha. Paris : Les Belles Lettres, 1999. La nature des dieux. Traduit et commenté par Clara Auvray-Assayas. Paris : Les Belles Lettres, 2002. Les devoirs. Texte établi et traduit par Maurice Testard. Paris : Les Belles Lettres, 1974-84. 2 t. Les paradoxes des stoïciens. Texte établi et traduit par Jean Molager. Paris : Les Belles Lettres, 1971. Sobre o destino. Tradução e notas José Rodrigues Seabra Filho. Edição bilíngüe. São Paulo: Nova Alexandria, 1993.

. Tusculanes. Texte établi par Georges Fohlen et traduit par Jules Humbert. Paris : Les Belles Lettres, 1997.

CHARRON, Pierre. De la sagesse. Texte revu par Bárbara de Negroni. Paris: Fayard, 1986.

DIÓGENES LAÉRCIO. Lives of eminent philosophers. With an english translation by R.D. Hicks. Cambridge, Mass.: Harvard University Press, 1991. 2v. Vidas e doutrinas dos filósofos ilustres. Tradução do grego, introdução e notas Mário da Gama Kury. Brasília: UnB, 1997.

DU VAIR, Guillaume. De la constance et consolation és calamitez publiques. Paris: par Mamert Parisson, Impremeur du Roy. Chez Rob. Estienne, 1594.

. De la Sainte Philosophie; Philosophie Morale des Stö̈ques. Édition annotée par G. Michaut. Paris : J. Vrin, 1945.

EPICTETO. Enquiridon. Estudio introductorio, traducción y notas de José Manuel Garcia de la Mora. En apéndice, la versión parafrástica de D. Francisco de Quevedo y Villegas. Barcelona: Anthropos; Madrid: MEC, 1991. - Entretiens. Texte établi et traduit par Joseph Souilhe. Paris : Les Belles Lettres, 1948-1995. 4t. . Manual de Epiteto filosofo. Trad. Frei Antonio de Souza. São Paulo: Cultura, $\mathrm{s} / \mathrm{d}$. 
The Discourses as reported by Arrain, the Manual, and Fragments. With an english translation by R.D. Hicks. Cambridge, Mass.; London: Harvard University Press, 1998. 2v.

LÍPSIO, Justo. De Constantia libri duo. Antuerpiae : Ex Officina Plantiniana : Apud Joannem Moretum, 1599.

. Les Deux Livres de la Constance: Esquels en forme de devis familier est discouru des afflictions, et principalement des publiques, et comme il se faut résoudre à les supporter. Traduction anonyme du latin. Edition de Tours (1592). Paris : Noxia, 2000.

. Opera omnia. Antuerpiae: Ex Officina Plantiniana Balthasaris Moreti, 1637. $4 \mathrm{t}$.

MARCO AURÉLIO. Meditações. Tradução de William Li. São Paulo: Iluminuras, 1995.

Pensées. Texte établi et traduit par A.I. Trannoy; preface d'Aimé Puech. Paris : Les Belles Lettres, 1953.

MELO, Francisco Manuel de. Obras Morales de Don Francisco Manuel a la Serenissima Reyna Catalina, Reyna de la Gran Bretaña. Roma: Falco, 1664. 2v.

QUEVEDO, Franciso de. Obras completas. Tomo I: Obras en prosa. 6 ${ }^{\mathrm{a}}$ ed. Madrid: Aguilar, 1992.

SÊNECA. Cartas a Lucílio. Tradução, prefácio e notas J.A. Segurado e Campos. Lisboa: Fundação Calouste Gulbenkian, 2004.

Consolationes. Dialogues, t.3. Texte établi et traduit par René Waltz. Paris :

Les Belles Lettres, 1950.

De Constantia sapientis. Commentaires par Pierre Grimal. Paris : Les Belles Lettres, 1953.

. De la Clémence. Texte établi et traduit par François Prechac. Paris : Les Belles Lettres, 1999.

Des bienfaits. Texte établi et traduit par François Préchac. Paris : Les Belles Lettres, 1926-1927. $2 \mathrm{t}$.

. De ira. Dialogues, t.1. Texte établi et traduit par A. Bourgery. Paris : Les Belles Lettres, 1951.

Lettres à Lucilius. Texte établi par François Préchac et traduit par Henri Noblot. Paris : Les Belles Lettres, 1969-1971. 5t. 
Questions naturelles. Texte établi et traduit par Paul Oltramare. Paris : Les Belles Lettres, 1929. 2t.

. Sobre a brevidade da vida. Tradução, notas e introdução de William Li. Edição bilíngüe. São Paulo: Nova Alexandria, 1993.

. Sobre a Divina Providência e Sobre a Firmeza do Homem Sábio. Tradução, introdução e notas de Ricardo da Cunha Lima. Edição bilíngüe. São Paulo: Nova Alexandria, 2000.

Sobre a tranqüilidade da alma; Sobre o ócio.Tradução, introdução e notas de José Rodrigues Seabra Filho. Edição bilíngüe. São Paulo: Nova Alexandria, 1994. . Sobre a vida feliz. Tradução, notas e introdução de João Teodoro d'Olim Marote. Edição bilíngüe. São Paulo: Nova Alexandria, 2005.

2. Estudos

ARNIM, Hans Friedrich August von. Stoicorum veterum fragmenta. 4v. Lipsiae: in aedibus B.G. Teubneri, 1903-24.

BERTHEAU, Gilles. "Passion et néoestoïcisme dans The Revenge of Bussy d'Ambois (1613) de George Chapman (1559?-1634)”, in: Études Epistémè, nº1, 2002, pp.6385.

BLÜHER, Karl Alfred. Séneca en España: investigaciones sobre la recepción de Séneca en España desde el siglo XIII hasta el siglo XVII. Versión española de Juan Conde. Edición corregida y aumentada. Madrid: Gredos, 1983.

BOBZIEN, Susanne. Determinism and freedom in stoic philosophy. Oxford: Clarendon Press, 2005.

BRÉHIER, Émile. Chrysippe et l'ancien stö̈cisme. Paris; New York : Gordon \& Breach, 1971.

BRUN, Jean. Le Stö̈cisme. Paris: PUF, 2003.

BRUNSCHWIG, Jacques (org.). Les Stö̈ciens et Leur Logique. Paris: J. Vrin, 2006.

CARABIN, Denise. Les idées stö̈ciennes dans la littérature morale des XVI et XVII siècles (1575-1642). Paris: Champion, 2004.

CARVALHO, José Adriano de. "A poesia sacra de D.Francisco Manuel de Melo". In: Arquivos do Centro Cultural Português. Paris: Fundação Calouste Gulbenkian, 1974, pp. 295-404. 
ETTINGHAUSEN, Henry. Francisco de Quevedo and the Neostoic Movement. Oxford: Oxford University Press, 1972.

FREDE, Michael. "The Stoic notion of lekton". In: Companions to ancient thought 3. Language. Edited by Stephen Everson. Cambridge; New York : Cambridge University Press, 1994, pp.109-128.

GOLDSCHIMIDT, Victor. Le système stö̈cien et l'idée de temps. Paris : J. Vrin, 1989.

ILDEFONSE, Frédérique. Les Stoïciens. Paris: Les Belles Lettres, 2000.

LAGRÉE, Jacqueline. Juste Lipse et la Restauration du Stö̈cisme. Paris: J. Vrin, 1994.

Le stö̈cisme au XVI et au XVII siècle: Le retour des philosophies antiques à l'âge classique. Tome I. Sous la direction de Pierre-François Moreau. Paris: Albin Michel, 1999.

Les Stoïciens. Textes traduits par Émile Bréhier; édités sous la direction de PierreMaxime Schuhl. Paris : Gallimard, 1997, 2v.

MANUPUELLA, Giacinto. "Acerca do cosmopolitismo intelectual de D. Francisco Manuel de Melo”. In: Brasilia, v.XI, Coimbra, 1961, pp.59-76.

MORFORD, Mark. Stoics and Neostoics. Rubens and the Circle of Lipsius. Princeton: Princeton University Press, 1991.

MUHANA, Adma. "Posfácio". Infortúnios trágicos da constante Florinda. São Paulo: Globo, 2006, pp.327-375.

MULLER, Robert. Les stö̈ciens : la liberté et l'ordre du monde. Paris : J. Vrin, 2006.

OESTREICHE, G. Neostoicism and the Early Modern State. Cambridge: Cambridge University Press, 1982.

PIRES, Maria Lucília G. "O tema da «guerra interior» nas Obras Métricas de D. Francisco Manuel de Melo". In: Xadrez de palavras: estudos de literatura barroca. Lisboa: Edições Cosmos, 1996, pp.53-74.

POHLENZ, Max Die Stoa: Geschichte einer geistigen Bewegung. Göttingen: Vandenhoeck \& Ruprecht, 1948-49.

SANDBACH, F.H. The Stoics. Bristol: Bristol Press, 1989.

SAUNDERS, J.L. Justus Lipsius: The Philosophy of Renaissance Stoicism. New York: The Liberal Arts Press, 1955.

SPANNEUT, Michel. Le stö̈cisme des pères de l'Église de Clément de Rome à Clément d'Alexandrie. Paris: Seuil, 1957.

Permanence du stö̈cisme de Zenon à Malraux. Bruxelles-Paris: Duculot, 1973. 
SPINA, Segismundo. "Introdução". A tuba de Caliope. São Paulo: Brasiliense; Edusp, 1988, pp. 15-21.

Stö̈cisme et Christianisme à la Renaissance, Cahiers V.L. Saulnier 23. Reponsable Catherine Magnien. Paris: Rue d'Ulm/Presses de l'École normale supérieure, 2006.

The Cambridge companion to the Stoics. Edited by Brad Inwood. Cambridge, U.K.; New York : Cambridge University Press, 2003.

VEYNE, Paul. Séneca y el estoicismo. Trad. de Monica Utrilla. México, D.F. : Fondo de Cultura Económica, 1995.

ZANTA, Léontine. La Renaissance du Stö̈cisme au XVI siècle. Thèse pour le Doctorat ès Lettres, présentée à la Faculté des Lettres de l'Unversité de Paris. Paris: Honoré Champion, 1914.

\section{Bibliografia complementar}

A Bíblia de Jerusalém. Nova edição, revista. São Paulo: Paulus, 1995.

AGUIAR E SILVA, Vitor Manuel de. Teoria da literatura. Coimbra: Almedina, 2000.

ARISTÓTELES. De Anima. Apresentação, tradução e notas de Maria Cecília Gomes dos Reis. São Paulo: Editora 34, 2006.

AUERBACH, Erich. Figura. Tradução de Duda Machado. São Paulo: Ática, 1997.

Le Culte des passions: Essais sur le XVII siècle français. Introduction et traduction par Diane Meur. Paris : Macula, 1998.

. Mimesis: a representação da realidade na literatura ocidental. São Paulo: Perspectiva, 2002.

BATAILlON, Marcel. Erasmo y España. Traducción de Antonio Alatore. México, D. F.: Fondo de Cultura Económica, 1996.

BENJAMIN, Walter. "O narrador". In: Magia e técnica, arte e política: ensaios sobre literatura e história da cultura. Obras escolhidas. V.1. Trad. Sérgio Paulo Rouanet. São Paulo: Brasiliense, 1985, pp.197-221.

Origem do drama barroco alemão. Tradução Sérgio Paulo Rouanet. São Paulo: Brasiliense, 1984.

BOÉCIO. La consolation de la philosophie. Traduction nouvelle avec une introduction et des notes par Aristide Bocagnano. Paris : Garnier Frères, 1937. 
Dicionário Houaiss da Língua Portuguesa. Rio de Janeiro: Objetiva, 2001.

FOUCAULT, Michel. Les mots et les choses : Une archéologie des sciences humaines.

Paris : Gallimard, 2007.

GILSON, Étienne. Introduction à la philosophie chrétienne. Paris : J. Vrin, 1960.

Introduction à l'étude de Saint Augustin. Paris : J. Vrin, 1982.

HARVEY, Paul. Dicionário Oxford de Literatura Clássica. Tradução Mário da Gama Kury. Rio de Janeiro: Jorge Zahar, 1987.

HAUSER, Henri. La Prépondérance Espagnole (1559-1660). Paris: Félix Alcan, 1933.

JAEGER, Werner. Cristianismo primitivo e Paideia grega. Tradução de Teresa Louro Perez. Lisboa: Edições 70, 2002.

. Paidéia: A Formação do Homem Grego. Tradução Artur M. Parreira. São

Paulo: Martins Fontes, 2003.

KRISTELLER, Paul. Tradição clássica e pensamento do Renascimento. Tradução de Artur Morão. Lisboa : Edições 70, 1995.

Le Grand Robert: Dictionnaire alphabétique et analogique de la langue française. $2^{e}$ éd. entièrement rev. et enrichie par Alain Rey. Paris: Le Robert, 1991. 9v.

Les fonctions des saints dans le monde occidental (III ${ }^{e}-X I I I^{e}$ siècle). Actes du colloque organisé par l'École française de Rome avec le concours de l'Université de Rome «La Sapienza ». Roma : École Française de Rome, 1991.

MARAVALL, José Antonio. La cultura del barroco: análisis de una estructura histórica. Barcelona : Editorial Ariel, 1990.

MARQUILHAS, Rita. A faculdade das letras: leitura e escrita em Portugal no século XVII. Lisboa: Imprensa Nacional-Casa da Moeda, 2000.

MENÉNDEZ PIDAL, Ramón (director). Historia de la cultura española: el siglo de Quijote (1580-1680). Org. Javier de Juan y Penalosa. Madrid: Espasa Calpe, 1996. $2 \mathrm{v}$.

Oxford Latin Dictionary. Edited by P.G.W. Glare. Oxford: Clarendon Press, 1968-1982. REBELO, Luis de Sousa. A tradição clássica na literatura portuguesa. Lisboa : Livros Horizonte, 1982.

SANTO AGOSTINHO. La cité de Dieu. Texte latin et traduction française, avec une introduction et des notes par Pierre de Labriolle. Paris : Garnier Frères, 19411946. $2 \mathrm{v}$.

A Cidade de Deus. Tradução, prefácio, nota biográfica e transcrições de J. Dias Pereira. 2ªed. Lisboa: Fundação Calouste Gulbenkian, 1996. 
SARAIVA, J. A. e Lopes, O. História da Literatura Portuguesa. $10^{\mathrm{a}}$ edição, corrigida e actualizada. Porto: Porto Editora, 1978.

SENAULT, Jean-François. De l'usage des passions. Texte revu par Christiane Frémont. Paris: Fayard, 1987.

SIMÕES, João Gaspar. História do romance português. Lisboa: Estúdios Cor, 1967. 3v. 